DÉBORA CHAVES MARTINES FERNANDES

\title{
CONTROLE JUDICIAL DA REPRESENTATIVIDADE ADEQUADA DAS ASSOCIAÇÕES CIVIS
}

\author{
Dissertação de Mestrado \\ Professora Orientadora Ada Pellegrini Grinover
}

Faculdade de Direito da Universidade de São Paulo

São Paulo

2013 
DÉBORA CHAVES MARTINES FERNANDES

\section{CONTROLE JUDICIAL DA REPRESENTATIVIDADE ADEQUADA DAS ASSOCIAÇÕES CIVIS}

Dissertação de Mestrado apresentada ao Departamento de Direito Processual ("DPC") da Faculdade de Direito da Universidade de São Paulo, como requisito parcial para obtenção do grau de Mestre. Professora Orientadora: Ada Pellegrini Grinover

São Paulo 
Nome: FERNANDES, Débora Chaves Martines.

Título: Controle Judicial da Representatividade Adequada das Associações Civis

Dissertação de Mestrado apresentada ao Departamento de Direito Processual ("DPC") da Faculdade de Direito da Universidade de São Paulo, como requisito parcial para obtenção do grau de Mestre. Professora Orientadora: Ada Pellegrini Grinover

Aprovado em:

\section{BANCA EXAMINADORA}

Prof. (a) Instituição:

Julgamento: Assinatura:

Prof. (a) Instituição:

Julgamento: Assinatura:

Prof. (a) Instituição:

Julgamento: Assinatura: 


\section{AGRADECIMENTOS}

Agradeço à professora Ada Pellegrini Grinover, que com sua orientação firme e zelosa me ajudou a estabelecer e cumprir meus objetivos durante a elaboração dessa dissertação.

À professora Susana Henriques da Costa que, além de me ajudar com esse trabalho, me permitiu acompanhá-la em suas aulas como monitora e, com isso, sentir o gostinho da tão gratificante carreira de professor.

Agradeço, ainda, aos meus pais, Sônia e Marcos, que me ensinaram o valor do conhecimento como a única coisa que ninguém pode nos tirar. E à minha irmãzinha Lígia, que ciente de todos os percalços optou por seguir também o caminho do Direito.

Ao Beto, companheiro, amigo, consultor, corretor incansável e exigente desse estudo. Essa vitória também é sua.

Aos meus amigos do escritório Sturzenegger e Cavalcante Advogados Associados, que muito me ajudaram a concluir esse trabalho ao compreenderem as demandas de uma jornada acadêmica.

E, por fim, agradeço aos amigos da vida. Não me atrevo a nomeá-los, sob pena de esquecer alguém importante e ser cobrada depois! Quem é meu amigo sabe que está nessa página, se não nominalmente, em intenção! Obrigada gente, por estarem ao meu lado, por me ajudarem no que eu precisei, por ouvirem todas as minhas reclamações e participarem dos tão indispensáveis momentos de descontração. Sem vocês eu não chegaria até aqui. 
Be great in act, as you have been in thought William Shakespeare

Procuro sempre, e minha procura ficará sendo minha palavra.

Carlos Drummond Andrade, A palavra mágica 


\section{RESUMO}

Nas últimas décadas foi instituído no Brasil um microssistema de processos coletivos, visando permitir a tutela dos direitos metaindividuais. No âmbito desse microssistema, o legislador atribuiu legitimidade ativa a alguns entes para defenderem em juízo tais interesses. Dentre esses entes estão órgãos ligados ao Estado, como o Ministério Público e a Defensoria Pública, e as associações - as quais, hoje, são as representantes da sociedade civil entre os colegitimados ativos do microssistema de processos coletivos.

A representatividade adequada é um dos pilares dos processos coletivos, na medida em que se presta a permitir a verificação da atuação dos legitimados ativos para a tutela dos interesses transindividuais. Isso porque a representatividade adequada é uma forma de assegurar a integral observância da garantia do devido processo legal no âmbito dos processos coletivos, nos quais os beneficiários da decisão - que terão suas esferas jurídicas afetadas por ela - não participaram diretamente.

Apesar de a necessidade de verificação da representatividade adequada estar positivada em diversos ordenamentos, isso não ocorre no Brasil. Em vista disso, este estudo tem como objetivo verificar se, à míngua de prescrição legal que autorize a aferição da representatividade adequada, poderia o juiz realizar essa a análise, especialmente no que concerne às associações civis.

A análise realizada passa pelo conceito de representatividade adequada e sua relação com a observância do devido processo legal. Em outro ângulo, enfocando-se a atuação das associações, procurou-se demonstrar que a aferição da representatividade adequada pelos juízes tem também a finalidade de coibir o abuso de direito e condutas atentatórias à boa-fé por parte das associações civis. Por fim, foi realizada uma análise qualitativa da jurisprudência pátria, buscando-se verificar de que forma os tribunais brasileiros têm aferido a representatividade adequada das associações no âmbito dos processos coletivos. 


\section{ABSTRACT}

In the last decades it was established in Brazil a special system of class actions, in order to allow the protection of collective interests and rights. In this special system, the legislator assigned to some entities institution that has been assigned legitimacy to pursue such interests. Some of these entities are connected to the government, such as the Public Prosecutors' Offices and Public Defenders, and the associations - which are, nowadays, the representatives of the civil society among the entities with legitimacy to pursue collective interests and rights.

The adequacy of representation is one of the touchstones of class actions, since it allows the verification of plaintiffs' performance in the defense of collective interests and rights. That occurs because litigation by representative parties adjudicates basic due process rights of all class members, named plaintiffs must possess undivided loyalty to absent class members that will be bound by the decision issued.

The rule that establishes mandatory verification of the adequacy of representation is set forth in several legal systems around the world, however that does not occur in Brazil. For this reason, this dissertation aims to determine whether the judge can verify the adequacy of the representation in Brazilian class actions especially in relation to associations, even though the law does not expressly authorize judges to do it.

This dissertation/thesis includes an analysis of the concept of adequacy of representation and its relation with the due process of law. In another angle, this dissertation/thesis focuses on the performance of associations' as plaintiffs in class actions, where in we try to demonstrate that the verification of adequacy of representation can help to mitigate the abuse of rights and acts contrary to good faith. Finally, we performed an analysis of a few cases, in order to verify the Brazilian courts understanding on the adequacy of representation of the associations in class actions. 


\section{SUMÁRIO}

1. INTRODUÇÃ

2. A DEFESA DOS INTERESSES TRANSINDIVIDUAIS EM JUÍzO:

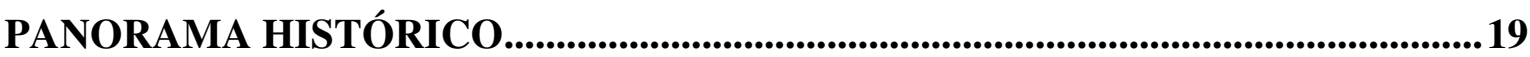

2.1. Ordenamentos Jurídicos do Sistema de Common LaW - A Tradição

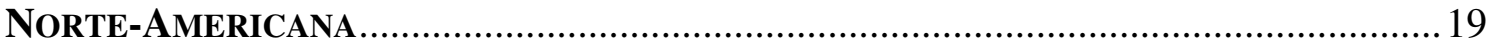

2.2. ORdenamentos JuRÍdicos do Sistema de Civil LAW ......................................29

2.2.1. Evolução da tutela coletiva de direitos no Brasil ..........................................30

2.2.2. A evolução da tutela coletiva em outros ordenamentos de Civil Law e o código modelo de processos coletivos para a Ibero-América..................................37

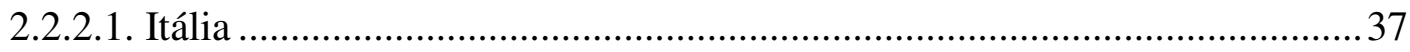

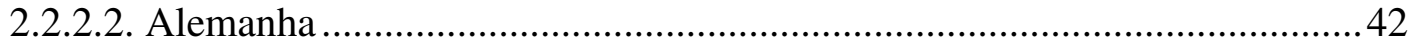

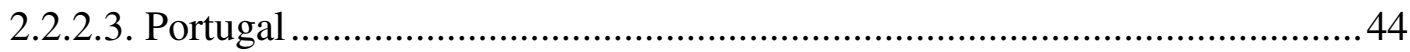

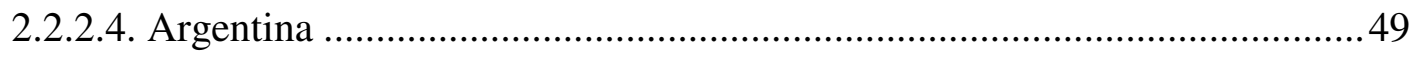

2.2.2.5. Código Modelo de Processos Coletivos para a Ibero-América ...................52

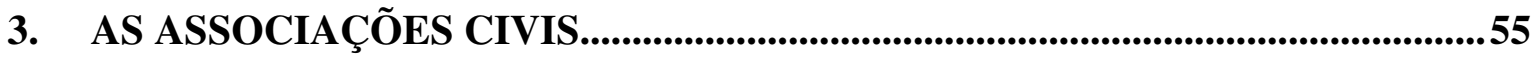

3.1. Panorama histórico - Repressão, tolerância e Fomento das ASSOCiaÇões na História Constitucional Brasileira .......................................55

3.2. As Associações Civis NA Legislação Brasileira EM Vigor: DA Constituição À EFETIVA ATUAÇÃo na DEFESA dos InTERESSES TranSINDIVIDUAiS

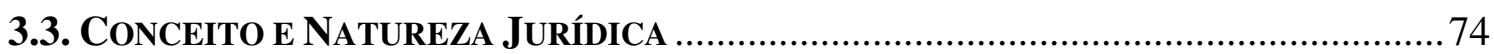

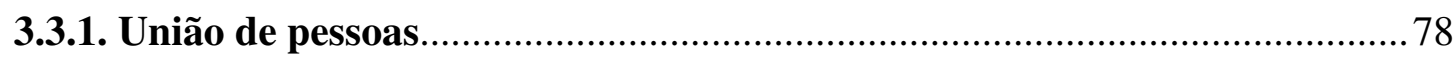

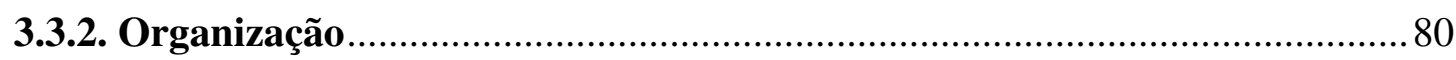

3.3.3. Desenvolvimento de finalidades não econômicas .......................................... 82

3.4. Principais Diferenças entre as Associações Civis e as demais Pessoas

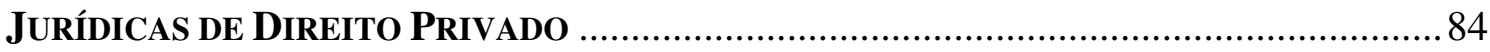

4. A LEGITIMIDADE AD CAUSAM NOS PROCESSOS COLETIVOS...............91

4.1. Apontamentos sobre as Condições da Ação nos Processos Coletivos .. 91

4.2. Legitimidade Ad CAUSAM: ConCeito e EvoluÇão 96 
4.3. A Natureza Jurídica da Legitimidade Ad Causam nos Processos Coletivos

4.4. Os Legitimados Ativos Para Tutela dos InTEReSSES Transindividuais EM Juízo 105

4.4.1. Os legitimados ativos ligados ao poder do Estado: Ministério Público, Defensoria Pública e Administração Pública direta e indireta 107

4.4.2. Aspectos da legitimidade das associações para a propositura de ações em defesa dos interesses transindividuais segundo os critérios estabelecidos expressamente pela legislação pátria 114

5. REPRESENTATIVIDADE ADEQUADA NAS AÇÕES COLETIVAS. 120

5.1. Discussões SOBRE O CONCEITO E A NATUREza JURÍdicA DA REPRESENTATIVIDADE ADEQUADA NO ORdENAMENTO JURÍDICO BRASILEIRO ........ 120

5.1.1. Evolução do conceito 120

5.1.2. Natureza Jurídica 126

5.2. A REPRESENTATIVIDAde AdEQUAda no Sistema NORTE-AMERICANO. 131

5.2.1. Precedentes dos tribunais norte-americanos determinantes para o desenvolvimento do conceito de representatividade adequada.

5.3. A REPRESENTATIVIDADE ADEQUADA EM OUTROS ORDENAMENTOS JURÍDICOS .. 138

5.3.1. Austrália e Canadá 139

5.3.2. Itália 143

5.3.3. Alemanha. 145

5.3.4. Portugal 147

5.3.5. Argentina 148

5.4. Propostas para positivação da Representatividade adequada No ORDENAMENTO JURÍDICO BRASILEIRO.

6. CONTROLE OPE JUDICIS DA REPRESENTATIVIDADE ADEQUADA DAS ASSOCIAÇÕES

6.1. PossibILIDAdE E NECESSIDADE DO CONTROLE JURISDiCIONAL DA REPRESENTATIVIDADE ADEQUADA

6.1.1. A representatividade adequada como forma de garantir a efetivação dos direitos e garantias previstos pela constituição brasileira 
6.1.2. A representatividade adequada como forma de garantir a preservação da boa-fé objetiva e evitar o abuso de direito de demandar nos processos coletivos 172

6.1.2.1. Dos fundamentos da vedação ao abuso de direito . 173

6.1.2.2. Os elementos do abuso de direito 178

6.1.2.3. Abuso do direito de demandar: uma das facetas do abuso de direitos no âmbito do processo

6.1.2.4. O papel do juiz no controle do abuso do direito de demandar: a caracterização do ato abusivo só poderá ser apurada in concreto mediante a aferição da representatividade adequada 186

6.2. FORMAS DE CONTROLE JURISDICIONAL DA REPRESENTATIVIDADE ADEQUADA: CONDUTAS ABUSIVAS DAS ASSOCIAÇÕES E COMO COIBI-LAS 193

6.2.1. Interpretação conjunta do Código Civil e do Código de Defesa do Consumidor para identificar as reais associações 196

6.2.2. As finalidades estatutárias como forma de controle da representatividade adequada: a excessiva amplitude dos objetivos institucionais e o abuso do direito de demandar 205

7. A POSIÇÃO DOS TRIBUNAIS BRASILEIROS QUANTO À AFERIÇÃO DA REPRESENTATIVIDADE ADEQUADA DAS ASSOCIAÇÕES................................214

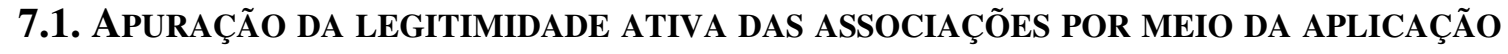
DOS CRITÉRIOS LEGAIS: ANÁLISE DA JURISPRUDÊNCIA DOMINANTE NOS TRIBUNAIS PÁTRIOS

7.1.2. Da pertinência temática como forma de aferir a representatividade adequada.

7.1.2.1. O caso da Associação de Bares e Restaurantes Diferenciados (ABREDI)

7.2. DEMAIS CRITÉRIOS QUE VÊM SENDO ESTABELECIDOS PELA JURISPRUDÊNCIA PARA AFERIR A REPRESENTATIVIDADE ADEQUADA DAS ASSOCIAÇÕES.

7.2.1. Do abuso da forma associativa: sociedades travestidas de associações ....223

7.2.1.1. O caso da Associação de Defesa da Cidadania e do Consumidor (ADECON/MS) 
7.2.1.2. O caso do Instituto de Defesa do Consumidor e do Contribuinte (IDC/SC)

7.2.2. Do abuso de direito: condutas contrárias à boa-fé

7.2.2.1. O caso da Associação Nacional de Assistência ao Consumidor e ao Trabalhador (ANACONT): venda de sentenças .................................................229

7.2.3.1. O caso da Associação de Proteção e Assistência ao Cidadão (ASPAC) ..231

7.2.3.2. O caso da Associação e Centro de Pesquisas Ecológicas de Ubarana (ACEPEUB). 233

7.3. A ATUAÇÃo do MiNistério PÚBlico COMO CUSTUS LEGIS E SUA INFLUÊNCIA NA AFERIÇÃO DA REPRESENTATIVIDADE ADEQUADA DAS ASSOCIAÇÕES: UMA ANÁLISE DE SUA ATUAÇÃO IN CONCRETO 235

8. CONCLUSÃ

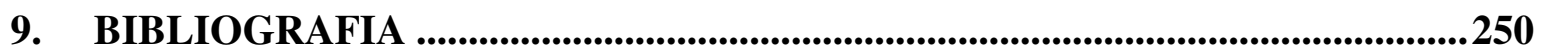




\section{INTRODUÇÃO}

O reconhecimento da existência de direitos concernentes a toda uma coletividade é o reflexo de um contexto social em que desde os acontecimentos corriqueiros até os atos e fatos jurídicos repercutem na esfera jurídica de um grande número de indivíduos, marca característica de uma sociedade de massa, na qual as interações humanas ocorrem em grande escala. Esse novo modelo social foi um dos principais responsáveis por ampliar a abrangência das relações jurídicas, que passaram a ultrapassar o âmbito puramente individual $^{1}$.

A amplitude e a dispersão desses interesses desde logo deixaram claras suas dimensões social e política, uma vez que, sem serem direitos públicos ou eminentemente privados, dizem respeito a um conjunto de pessoas e desafiam uma forma nova e específica de gestão e de tutela jurisdicional ${ }^{2}$ - já que esta, até então, estava voltada para a solução de conflitos individuais ${ }^{3}$.

A importância desses direitos foi contemplada em nível constitucional por meio da criação de uma nova geração de direitos fundamentais. Na maior parte das democracias ocidentais, somaram-se aos direitos fundamentais de primeira geração as liberdades públicas que pressupõem o dever de abstenção do Estado, e aos direitos fundamentais de segunda geração (de caráter socioeconômico e relativos a uma obrigação de "prestar" por parte do Estado) os chamados direitos fundamentais de terceira geração, conhecidos também por direitos de solidariedade, relativos à coletividade, verdadeiros direitos transindividuais (e.g. interesses dos consumidores, dos usuários de serviços públicos, dos investidores, direito à manutenção de um meioambiente equilibrado, etc.). Mas como não bastava reconhecer a existência e a importância desses direitos, sendo necessário, também,

\footnotetext{
1 SHIMURA, Sérgio. Tutela coletiva e sua efetividade. São Paulo: Editora Método, 2006, p. 33-34. Conforme será analisado no panorama histórico desenvolvido no capítulo 2 , conquanto as ações representativas existam desde a Idade Média e tenham se manifestado em outros períodos ao longo do século $\mathrm{XX}$, foi a partir da segunda metade desse mesmo século, com a intensificação das relações sociais, que elas ganharam especial destaque.

${ }^{2}$ GRINOVER, Ada Pellegrini. Significado social, político e jurídico da tutela dos interesses difusos. Revista de Processo (Estudos em homenagem ao Min. Sálvio de Figueiredo Teixeira), São Paulo: Ed. Revista dos Tribunais, n. 97, 2000, p. 9-10.

3 ARRUDA ALVIM, José Manoel de. Ação Civil Pública - sua evolução normativa significou crescimento em prol da proteção às situações coletivas. In: Édis Milaré (coord.). A ação civil púlbica após 20 anos: efetividade e desafios, São Paulo: Ed. Revista dos Tribunais, 2005, p. 73.
} 
garantir sua efetiva tutela e assegurar sua fruição pela sociedade, a disciplina tomou corpo e ganhou visibilidade no campo do processo ${ }^{4}$.

Desta forma, é possível dizer que a criação e o desenvolvimento do conceito de direitos coletivos e dos mecanismos processuais atinentes à sua defesa em juízo foram, antes de tudo, uma exigência social.

A evolução da disciplina do direito processual civil no Brasil, nas últimas três décadas, deu-se no bojo das ideias relativas à ampliação do acesso à justiça, como movimento que tem como escopo possibilitar que o sistema judicial seja acessível a todos e garantir que, sob os auspícios do Estado, as partes envolvidas em determinado litígio obtenham resultados individual e socialmente justos ${ }^{5}$ em um tempo razoável ${ }^{6}$. Tendo isso em vista, a legislação brasileira passou a positivar diversos meios processuais especialmente desenhados para dar vazão à litigiosidade contida, dentre elas ações destinadas à tutela dos interesses transindividuais ${ }^{7 \mathrm{e} 8}$.

Com algumas diferenças que serão exploradas no decorrer do presente estudo, essas ações se desenvolveram nos países de Civil Law - como Brasil, Argentina, Portugal, Itália e Alemanha - durante a segunda metade do século XX, tendo havido, inclusive, progressos quanto a ordenamentos supranacionais sobre o tema ${ }^{9}$. A experiência dos países de Common Law em ações dessa natureza - a exemplo das Class Actions norte-americanas -, conquanto bem mais antiga, também se intensificou a partir da década de 60, acompanhando justamente a evolução da sociedade massificada.

\footnotetext{
${ }^{4}$ GRINOVER, Ada Pellegrini. Significado social, político...Op. cit., p. 9-10. Sobre o tema, ver, também, CAPPELlETTI, Mauro. Formações sociais e interesses coletivos diante da justiça civil. Revista de Processo, São Paulo: Ed. Revista dos Tribunais, ano 2, n. 5, jan/mar. 1977, p. 128-159.

5 CAPPELleTTI, Mauro; GARTH, Bryant. Acesso à justiça. Tradução: Ellen Gracie Northfleet. Porto Alegre: Sérgio Fabris Editor, 2002, p. 8.

${ }^{6}$ A duração razoável dos processos foi, inclusive, erigida ao patamar de direito fundamental na Constituição Federal de 1988, pela Emenda Constitucional no $45 / 2004$, que acresceu ao artigo $5^{\circ}$ o inciso LXXVIII (a todos, nos âmbitos judicial e administrativo, são assegurados a razoável duração do processo e os meios que garantam a celeridade de sua tramitação). Esse requisito já havia sido contemplado pela constituição de outros países, como a Itália, como um dos pilares do processo justo e équo. Ver, nesse sentido, COMOGLIO, Luigi Paolo. Etica e Tecnica del “Giusto Processo". Torino: G. Giappichelli Editore, 2004, p. 39-93.

${ }^{7}$ SHIMURA, Sérgio. Tutela Coletiva e sua efetividade...Op. cit., p. 34.

${ }^{8}$ Outros avanços legislativos nesse sentido, que se podem citar como exemplos, são as tutelas específicas previstas, a Lei no 9.099/95 (que prevê a criação dos Juizados Especiais Cíveis e Criminais), entre outros.

${ }^{9}$ Cita-se, como exemplo, o Anteprojeto do Código de Processos Coletivos para a Ibero-América, através do qual se buscou criar bases comuns entre países que guardassem entre si identidade linguística, jurídica e social - no caso, as nações latino-americanas, juntamente com Portugal e Espanha -, para uma uniformização das normas atinentes à tutela dos interesses transindividuais. Essa iniciativa teve grande relevância do ponto de vista jurídico, pois permitiu o desenvolvimento da disciplina em países que anteriormente não tinham uma legislação específica sobre o tema e, também, do ponto de vista socioeconômico, dentro do contexto de abertura das fronteiras e formações de mercados comuns (a exemplo do MERCOSUL). Ver GRINOVER, Ada Pellegrini; WATANABE, Kazuo; MULLENIX, Linda. Os processos coletivos nos países de Civil Law e Common Law - uma análise de direitos comparados. 2.ed. São Paulo: RT, 2011, p. 9.
} 
Seja como for, essas ações coletivas foram indispensáveis para o desenvolvimento sócio-jurídico de todos os países onde foram implementadas, uma vez que trouxeram consigo ideias de ampliação do acesso à Justiça em seu mais amplo espectro. Os principais planos enfeixados nesse ideário, tanto no Brasil quanto nos demais países, foram: (i) em um primeiro momento a criação de mecanismos para possibilitar a tutela de interesses dispersos entre um grande número de titulares, identificáveis ou não (tutela de direitos difusos e coletivos), e (ii) em um segundo momento a criação de mecanismos para que as lesões de pequena expressividade econômica no âmbito individual - e que por uma questão de custo-benefício não ensejariam a propositura de uma ação pelo lesado - fossem levadas a juízo conjuntamente, ensejando não apenas a reparação dos danos como, também, o desestímulo à prática de condutas análogas (tutela dos interesses individuais homogêneos) $)^{10}$.

Outro fator contemplado pela criação dessas formas de tutela coletiva, foi o aumento do equilíbrio entre as partes do processo, uma vez que foram dotados determinados entes de legitimidade ativa para defender judicialmente os direitos transindividuais, selecionando os que têm melhores condições de propor demandas e defender adequadamente tais interesses contra os chamados litigantes habituais, tais como fornecedores, empresas, administrações públicas e etc. Esses litigantes teriam, entre outras vantagens: (i) maior experiência com o Direito; (ii) melhores condições de planejar o litígio; (iii) economia de escala, dado o grande número de processos com que lidam diariamente; e (iv) diluição de risco, dado o número de casos; (vi) volume de processos que lhes permite testar estratégias ${ }^{11}$.

\footnotetext{
${ }^{10}$ Sobre o assunto, pontua Aluísio Gonçalves de Castro Mendes: "A eventual falta ou deficiência dos instrumentos processuais adequados para a os chamados danos de 'bagatela', que, considerados globalmente, possuam geralmente enorme relevância social e econômica, estimula a repetição e perpetuação de práticas ilegais e lesivas. Por conseguinte, tendem a se beneficiar, em vez de serem devidamente sancionados, os fabricantes de produtos defeituosos de reduzido valor, os entes públicos que cobram tributos indevidos ou não concedem os direitos funcionais cabíveis e os fornecedores que realizam negócios abusivamente, apenas para citar alguns exemplos. De pouca ou nenhuma valia passam a ser as normas de direito material, que estabelecem direitos para os lesados, se a referida proteção não encontra, também, amparo efetivo nos meios processuais disponíveis." (MENDES, Aluísio Gonçalves de Castro. Ação coletiva no direito comparado e nacional. 2. ed. Revista e atualizada - temas atuais de processo civil. Vol. 4. São Paulo: RT: 2010, p. 28).

${ }^{11}$ Sobre o assunto, Mauro Cappelletti e Bryant Garth discorrem a respeito do embate entre litigantes "habituais" e litigantes "eventuais", criando essa terminologia para descrever o impacto do desequilíbrio entre as partes no contexto de ampliação do acesso à justiça. Dizem pois, que "[...] os obstáculos criados por nossos sistemas jurídicos são mais pronunciados para as pequenas causas e para os autores individuais, especialmente os pobres; ao mesmo tempo, as vantagens pertencem de modo especial aos litigantes organizacionais, adeptos do uso do sistema judicial para obterem seus próprios interesses" (CAPPELLETTI, Mauro; GARTH, Bryant. Acesso à justiça...Op. cit., p. 25-28).
} 
Assim, em um processo individual, os litigantes habituais teriam chances de êxito muito maiores, devido a uma maior disponibilidade de informações e capacidade logística para lidar com demandas. No processo coletivo essa distorção pode ser amenizada, vez que, como assinala Aluísio Gonçalves de Castro Mendes:

\begin{abstract}
A possibilidade de os interesses e direitos lesados serem defendidos concomitantemente faz com que a correlação de forças entre os litigantes seja redimensionada em benefício da parte individualmente fraca, mas razoavelmente forte quando agrupada, levando por terra, assim, a política maquiavélica da divisão para reinar ${ }^{12}$.
\end{abstract}

Ademais, as ações coletivas se prestariam a aumentar a eficiência do sistema jurisdicional, tanto do ponto de vista da economia processual - possibilitando a tutela dos interesses dispersos de forma grupal e impedindo a disseminação de demandas individuais -, quanto do ponto de vista da segurança jurídica - mediante o tratamento igualitário pelo Poder Judiciário de situações em que o direito material é idêntico, reduzindo o número de soluções contraditórias geralmente prolatadas nos processos individuais, especialmente em matérias que geram numerosas ações ${ }^{13}$.

Por todos esses motivos, a criação de um sistema de defesa dos direitos transindividuais foi de fundamental importância para o panorama jurisdicional brasileiro, em que o grande número de demandas e o elevado custo de manutenção de um processo consistem, efetivamente, em obstáculos a serem superados para garantir o pleno acesso à Justiça. A evolução dessa disciplina, ao longo das três últimas décadas, foi notável. E as discussões e propostas acerca de melhorias - quanto ao seu conteúdo e à sua organização têm sido constantes ${ }^{14}$.

E uma das preocupações que vem permeando a evolução histórica dessa matéria, desde as suas primeiras manifestações, é a representação daqueles que não participam

\footnotetext{
${ }^{12}$ CASTRO MENDES, Aluísio Gonçalves de. Ação coletiva no direito...Op. cit., p. 36.

${ }^{13}$ Ibid., p. 31-36.

${ }^{14}$ Prova disso foram as constantes tentativas de positivar um Código Brasileiro de Processos Coletivos, tendo sido propostos dois anteprojetos - um deles foi elaborado e teve sua gênese no curso de pós-graduação da Faculdade de Direito da Universidade de São Paulo em 2003, sob a tutela dos professores Ada Pellegrini Grinover e Kazuo Watanabe e o outro foi elaborado no ano de 2005, pelos alunos do curso de pós-graduação da Universidade Estadual do Rio de Janeiro e da Universidade Estácio de Sá, orientados pelo professor Aluísio Gonçalves de Castro Mendes. Ver, sobre o tema, a exposição de motivos do Código Brasileiro de Processos Coletivos, elaborada pela Professora Ada Pellegrini Grinover, disponível em http://www.mpcon.org.br/site/portal/jurisprudencias_detalhe.asp?campo=2897. Acessado em 28jun.2011. Além desses anteprojetos, tramitou no Congresso Nacional o Projeto de Lei $\mathrm{n}^{\circ}$ 5.139/2009, que propunha uma reforma na Lei da Ação Civil Pública, visando sistematizar toda a legislação acerca dos processos coletivos. Tal processo, no entanto, foi rejeitado em março de 2010, sendo que ainda há um recurso pendente. Texto e tramitação disponíveis em http://www.camara.gov.br/proposicoesWeb/fichadetramitacao? idProposicao=432485. Acessado em 20jun. 2011.
} 
diretamente da relação jurídica processual, mas que, por pertencerem à determinada coletividade, serão atingidos pela eficácia da decisão judicial. Esse ponto é crucial porque se de um lado é indispensável garantir o contraditório e a ampla defesa a todos aqueles cuja esfera jurídica será afetada pelo resultado da demanda, de outro os objetivos colimados pelo sistema de tutela dos direitos coletivos só podem ser efetivados através da atribuição da legitimidade ativa, em caráter autônomo e extraordinário, a entidades capazes de representar e defender os direitos sociais em juízo.

Isso porque apenas por meio da representação dos indivíduos em juízo é que se possibilita a fruição dos benefícios de um amplo acesso ao Poder Judiciário pelos integrantes de determinada coletividade de forma mais paritária - do ponto de vista econômico e informativo - e mais racional -, evitando a propositura de milhares de demandas individuais e, ao mesmo tempo, permitindo a tutela de situações que, em outras circunstâncias, talvez não fossem levadas à justiça ${ }^{15}$.

Tendo isso em vista, a legitimidade ativa extraordinária ocupa lugar de destaque na sistemática dos direitos transindividuais, uma vez que a atuação do legitimado ativo em juízo terá reflexos na decisão judicial e, em última análise, na esfera jurídica de todos os indivíduos pertencentes à determinada classe e que não integraram de forma direta a relação processual. O legislador brasileiro optou por atribuir legitimidade ativa extraordinária a entes ligados ao poder do Estado - a exemplo do Ministério Público e da Defensoria Pública - e aos representantes da sociedade civil organizada ${ }^{16}$, i.e. as associações.

A legitimidade ativa atribuída a essas entidades associativas para a propositura de ações em defesa dos interesses transindividuais e a sua efetiva aptidão para defender tais direitos são o foco principal do presente estudo. Isso porque as associações são a efetiva expressão da aglutinação de interesses no seio da sociedade. E a possibilidade de esses grupos ingressarem em juízo para defender seus propósitos institucionais - em benefício não apenas de seus associados, mas de toda coletividade - deixa clara a importância da participação social na concretização dos direitos transindividuais.

Entrentanto, dado o fato de que esses grupos surgem espontaneamente, por iniciativa dos indivíduos e sem controle ou vínculo estatal, não é possível assegurar previamente que as associações se empenharão na defesa dos interesses da coletividade. A

${ }^{15}$ CAPPELLETTI, Mauro; GARTH, Bryant. Acesso à justice...Op. cit., p. 28.

${ }^{16}$ MANCUSO, Rodolfo de Camargo. Interesses difusos: conceito e legitimação para agir. São Paulo: RT, 2000 , p. 34. 
verificação da qualidade da atuação da entidade associativa só poderá ser feita no caso concreto, pelo juiz. É nesse contexto que se insere a necessidade de aferição ope judicis da representatividade adequada das associações.

A representatividade adequada é um conceito que está intimamente ligado com a tutela dos interesses metaindividuais desde a sua gênese, uma vez que a única forma de assegurar a efetivação da garantia constitucional do devido processo legal no processo coletivo é verificando se o legitimado ativo atua com vigor, técnica e idoneidade compatíveis com o que seria a atuação do próprio titular do direito. A discussão que se trava na doutrina pátria, no entanto, refere-se à possibilidade de aferir a representatividade adequada dos legitimados ativos escolhidos pelo legislador - entre eles as associações -, tendo em vista o fato de que essa possibilidade não foi prevista expressamente no ordenamento jurídico brasileiro e, tampouco, foram estabelecidos parâmetros para que tal verificação fosse realizada.

Assim, pretende-se analisar se, mesmo sem previsão legal específica, os juízes brasileiros podem realizar o controle da representatividade adequada das associações civis enquanto autoras de processos coletivos e de que forma essa aferição pode ser feita, com base em dispositivos já positivados na legislação pátria.

A análise partirá de uma introdução histórica, indispensável para que se compreenda o desenvolvimento dos sistemas de tutela de interesses transindividuais desde sua gênese nos países de Common Law até a sua implementação no Brasil e em alguns outros países de Civil Law, e a correlação intrínseca existente entre o conceito de tutela coletiva e o instituto da representatividade adequada. A incursão no tema em si dar-se-á pela via do estudo das questões ligadas às associações - desde a evolução histórica do tratamento dessas entidades pela sociedade e pela legislação pátria até os elementos que permitem caracterizar um agrupamento de pessoas como associação -, visando entender os motivos que levaram o legislador a conferir aos entes associativos a legitimidade ativa para defender os interesses da coletividade.

Em seguida, a análise se voltará ao instituto da legitimidade ad causam, enquanto uma das condições da ação e pedra de toque dos processos coletivos. A ideia é verificar de que forma se deu a evolução da legitimidade ativa, inicialmente atribuída aos titulares de determinado direito material - no âmbito do processo individual - para permitir que terceiros ingressassem em juízo em nome próprio mas visando a tutela dos interesses da coletividade. Discutir-se-ão, na mesma oportunidade, as teorias acerca da natureza jurídica 
da legitimidade ad causam nos processos coletivos e, ainda, cada uma das entidades a quem o legislador brasileiro permitiu o ingresso em juízo para a defesa dos direitos transindividuais (artigos $5^{\circ}$ da Lei da Ação Civil Pública e 82 do Código de Defesa do Consumidor). Por fim, serão analisados os requisitos que as associações civis devem atender, de acordo com a legislação vigente, para que a ela seja atribuída a legitimidade ativa para a propositura de ações na defesa dos interesses da coletividade.

Essa discussão servirá de base para o estudo da representatividade adequada, que está intimamente ligada à legitimidade ad causam e é considerada por parte da doutrina como um princípio do processo coletivo. A análise do conceito e da natureza jurídica desse instituto que até o presente momento não foi positivado no ordenamento jurídico brasileiro, permitirá entrever que sua principal função é assegurar a efetivação da garantia constitucional do devido processo legal (contraditório e ampla defesa), mediante um escrutínio sobre a idoneidade, seriedade e capacidade daquele que vai a juízo para pleitear direitos de pessoas que não integram a relação jurídica processual. Será feita, ainda, uma incursão em outros ordenamentos jurídicos de common law e civil law, buscando verificar como a representatividade adequada é tratada nas legislações dos países que adotam esses sistemas. Partindo dessa análise do direito estrangeiro, serão abordados os anteprojetos e projetos de lei que foram propostos no Brasil, verificando de que forma foi abordado o tema, e por que a previsão expressa da possibilidade de aferição da representatividade adequada, bem como a fixação de alguns critérios para pautar a conduta do juiz nesse tocante, pode trazer benefícios para a defesa dos direitos transindividuais no país.

Fixadas as premissas teóricas e conceituais, o estudo prosseguirá com a análise da possibilidade de aferição da representatividade adequada pelos juízes brasileiros, ainda que não exista previsão expressa que autorize essa verificação. Serão abordados os motivos pelos quais esse controle pode ser realizado ope judicis no Brasil, partindo da necessidade de assegurar o devido processo legal nos processos coletivos - bem como a incolumidade das esferas jurídicas dos ausentes - e passando pela obrigatoriedade de se coibir o abuso de direito no âmbito do processo. Isso porque a verificação dos elementos que compõem a representatividade adequada - entre eles seriedade, idoneidade, capacidade técnica - é a melhor forma de garantir o contraditório e a ampla defesa no processo coletivo, além de ser capaz de evitar condutas abusivas conduzidas pelas associações buscando benefício próprio e não a defesa dos interesses transindividuais. 
Serão apontadas formas de se realizar esse controle, visto que não existem parâmetros positivados no ordenamento jurídico do país. A discussão se dará sob o prisma da legislação vigente - aplicação conjunta do Código Civil e das leis que compõem o microssistema de tutela dos interesses coletivos -, da cláusula geral de boa-fé e a consequente vedação ao abuso de direito, aplicada ao âmbito processual.

A pesquisa prosseguirá com a análise de acórdãos e decisões dos tribunais brasileiros que abordam o tema da representatividade adequada, buscando entender de que forma o instituto tem sido aplicado na prática e quais os fundamentos utilizados pelos julgadores para a utilização dele como base para conferir ou negar a legitimidade a determinado autor coletivo, uma vez que os critérios para sua aferição não foram especificados pelo legislador. Será analisada também a atuação do Ministério Público como custus legis nas ações coletivas, verificando de que forma ela pode auxiliar o juiz na aferição da representatividade adequada das associações autoras.

Com isso, procurar-se-á comprovar que o controle da representatividade adequada ope judicis no país não apenas é possível como já vem sendo realizado por alguns juízes e tribunais, independentemente de previsão legal específica nesse sentido - seja acerca da possibilidade do controle judicial ou dos parâmetros para realizá-lo. É certo que as condutas perpetradas pelas associações que deixam clara a falta de representatividade adequada para a tutela dos interesses coletivos são tantas quantas a criatividade humana pode imaginar e, por esse motivo, só podem ser verificadas e coibidas na prática, quando da propositura da ação coletiva. E conquanto defenda-se que tal controle já pode ser realizado, a positivação do conceito e de parâmetros para sua aferição pelos juízes seria indispensável para a manutenção e evolução do microssistema de direitos coletivos no Brasil. 


\section{A DEFESA DOS INTERESSES TRANSINDIVIDUAIS EM JUÍZO: PANORAMA HISTÓRICO}

Traçar um panorama histórico das ideias e necessidades sociais que determinaram o desenvolvimento do arcabouço jurídico para a tutela dos interesses transindividuais em juízo, desde sua gênese nos ordenamentos de Common law até sua adoção pelos países que adotam o sistema de Civil law, é de extrema importância para a análise do tema, já que possibilitará uma posterior análise também da importância do instituto da representatividade adequada e do papel das associações na defesa dos direitos coletivos, bem como possibilitará entender a forma como esse tipo de tutela foi adaptada à realidade do Brasil.

Por esse motivo, inicia-se o estudo pela forma como o ideário da defesa dos direitos coletivos se iniciou, ainda na Inglaterra da Idade Média, e a forma como essas ações representativas evoluíram até as conhecidas Class Actions norte-americanas - expressão máxima da tutela dos interesses transindividuais na atualidade. Será feita, ainda, uma análise de alguns ordenamentos de países que adotam a tradição romanística, cuja seleção se fez levando em consideração os locais em que o desenvolvimento do sistema de defesa dos direitos coletivos gerou discussões que influenciaram outros países no mesmo sentido.

\subsection{ORDENAMENTOS JURÍDICOS DO SISTEMA DE COMMON LAW - A TRADIÇÃO NORTE-AMERICANA}

Conquanto a experiência norte-americana seja referência para o estudo de qualquer tema relacionado à tutela coletiva de direitos, bem como os Estados Unidos da América sejam, hoje, o maior país que adota o sistema de Common law, é certo que as raízes mais distantes dos litígios coletivos estão plantadas na Inglaterra.

Desde a Idade Média (meados do século XII), há registros de estudiosos e historiadores acerca da existência na Inglaterra de demandas movidas por representantes em benefício de determinados grupos e, também, pleitos contra uma coletividade representada por alguns de seus integrantes. O professor norte-americano Stephen Yeazell, ao estudar as primeiras manifestações de litígios coletivos no direito inglês, segmentou o desenvolvimento dessas ações em três momentos: (i) medieval entre os século XII e XV; 
(ii) primitivo-moderno que compreende os séculos XVI e XVII e moderno, do século XVIII em diante. ${ }^{17}$

O sistema de justiça na Inglaterra, até o ano de 1873, era dual - dividido em “jurisdição do direito" (law jurisdiction) e "jurisdição de equidade" (equity jurisdiction) -, cada qual aplicado por um tribunal específico. O sistema de equity era aplicado pelas Courts of Chancery e era caracterizado pela flexibilidade de seus procedimentos, decisões e provimentos, diferentemente daqueles encontrados no sistema de law - mais formais, rígidos e burocráticos. Em virtude disso, foi nesses tribunais de equity que se desenvolveram as ações de vocação coletiva ${ }^{18}$.

Isso porque os tribunais de equidade, em oposição ao que acontecia nos tribunais de direito, admitiam a formação de litisconsórcio - ativo ou passivo - fundado na existência de questões comuns. Com base nessa possibilidade, e com o objetivo de evitar a multiplicação de demandas sobre o mesmo assunto, criou-se uma regra que determinava a intervenção compulsória de todas as pessoas que poderiam ter algum interesse no processo, sob pena de extinção do feito (compulsory joinder rule/ necessary parties rule ou regra geral do litisconsórcio integral). Com o tempo, entretanto, percebeu-se que essa regra acabava, em alguns casos, criando dificuldades intransponíveis - pois existiam casos em que o número de litisconsortes era grande demais e sua atração para o polo ativo da lide era inviável -, e a extinção do processo nesses casos acabava impedindo a prestação jurisdicional e criando situações de verdadeira injustiça ${ }^{19}$.

Buscando sanar esses inconvenientes e, já então, remover eventuais entraves à efetivação da justiça, as Courts of Chancery, aplicadoras da jurisdição de equidade, criaram o Bill of Peace, que previa exceções à regra geral do litisconsórcio integral, passando a aceitar as ações representativas (representative actions) - caracterizadas pela circunstância de que alguns membros do grupo poderiam representar em juízo os interesses de todos os demais. No entanto, justamente por se tratarem de exceções à regra do litisconsórcio, para que fossem cabíveis as ações representativas, o grupo deveria ser tão

\footnotetext{
${ }^{17}$ YEAZELL, Stephen C. From medieval group litigation to the modern class action. New Haven: Yale University Press, 1987, p. 30-39. Nesse sentido, ver também: MENDES, Aluísio Gonçalves de Castro. Ação coletiva no direito comparado e nacional...Op. cit, p. 38.

${ }^{18}$ Esclarece, ainda sobre o tema, Antonio Gidi que a diferença básica que se poderia fazer entre os tribunais de direito e de equidade, no que tange à esfera de atuação, é que os primeiros teriam jurisdição primordialmente sobre pretensões de natureza pecuniária e indenizatória enquanto os segundos teriam jurisdição sobre pretensões declaratórias, injuntivas e mandamentais. Bem por isso, nesses primeiros tempos, não se observavam ações coletivas que veiculassem pretensões indenizatórias. (GIDI, Antonio. A Class Action como instrumento de tutela coletiva dos direitos. São Paulo: RT, 2007, p. 40-41).

${ }^{19}$ Ibid., p. 41.
} 
numeroso a ponto de inviabilizar o litisconsórcio e os interesses tutelados deveriam ser comuns a todo o grupo - inclusive ao representante ${ }^{20}$. Essas características, que deveriam ser observadas para viabilizar o cabimento das ações coletivas nos tribunais de equity da Inglaterra do século XVI e XVII, perpetuaram-se no tempo e, como será visto adiante, permanecem como requisitos das Class Actions moderna (numerosity, commonality) ${ }^{21}$.

Desde a sua gênese, as ações que tinham no polo ativo ou passivo um determinado grupo de indivíduos foram concebidas com o objetivo de obter uma tutela mais econômica e eficiente ${ }^{22}$ de interesses que fossem comuns a todos os integrantes da coletividade representada em juízo, impedindo a proliferação de ações com o mesmo tema. Em outras palavras, a lógica por trás da praxe dos tribunais ingleses da época, quando passaram a aceitar esse tipo de demanda, era "o surgimento de uma demanda em vez do surgimento de duas demandas" 23 .

Ademais, a criação de remédios judiciais que possibilitassem a solução dos problemas compartilhados por todo um grupo de indivíduos foi reflexo da organização da sociedade, que reunia as pessoas em estamentos de cunho social e político - os agrupamentos eram preexistentes aos conflitos e as pessoas já estavam unidas por laços relativos ao seu status na organização local. Nessa época, as instituições intermediárias como a igreja, as classes sociais e as ordens profissionais eram a base do sistema social e de produção da época, de modo que, nos primórdios das ações coletivas, observavam-se demandas de membros do clero contra seus paroquianos ${ }^{24}$ e de proprietários dos lotes de

\footnotetext{
${ }^{20}$ Ibid., p. 42. O autor ressalta, citando o jurista norte-americano Zechariah Chafee, que "a identidade dos interesses que unia os membros do grupo, ao mesmo tempo em que tornou possível trazê-los todos a um mesmo processo, também tornou supérfluo fazê-lo."

${ }^{21}$ Requisitos de certificação positivados na Rule 23 do direito norte-americano, entre os quais estão a numerosity (Rule 23 (a) (1)) - o grupo deve ser tão numeroso que o litisconsórcio de todos os membros seja impraticável - e a commonality (Rule 23 (a) (2)) (haver questões de direito e/ou de fato comuns aos membros do grupo).

${ }^{22}$ Nos países que adotam o sistema de Common law, particularmente Inglaterra e Estados Unidos da América, a eficiência é um valor muito prezado, não apenas na esfera jurídica. Ver: POSNER, Richard A. Economic analysis of law. 5. ed. Aspen: A division of Aspens Publishers, Aspen Law \& business, p. 25-29.

23 Tradução livre do trecho citado por Stephen C. Yeazell, in verbis: "[...] there is the assumption that efficiency was the guiding force behind Chancery's acceptance of this sort of case, the desire, as Chafee elsewhere put it, to make 'one law suit grow where two grew before' by aggregating multiparty common law litigation". YEAZELL, Stephen. Group litigation and social context: toward a history of the Class Action. Columbia: Law Review, n. 866, 1977, p. 868.

${ }^{24}$ Entre os primeiros casos de demanda coletiva, cujos registros históricos datam do ano de 1190, está um que trata de uma demanda ajuizada por um pároco do povoado de Barkway, contra seus paroquianos, acerca de oferendas e serviços que deveriam ser prestados por estes últimos. Os paroquianos foram considerados como grupo e o juízo convocou apenas algumas pessoas para responder por todos. Ver: MENDES, Aluísio Gonçalves de Castro. Ações coletivas no direito comparado e nacional...Op. cit., p. 38.
} 
terra contra seus arrendatários ${ }^{25}$.E a defesa desses grupos no processo era perpetrada por seus líderes, de forma intuitiva e natural ${ }^{26}$.

O fortalecimento do ideário individualista no curso dos séculos XVIII e XIX, atrelado ao desenvolvimento de grupos dotados de personalidade jurídica, marcou o declínio das ações representativas no direito inglês. Muito embora elas tenham sido contempladas no texto das Rules of Procedure, quando da unificação das jurisdições de equity e de law (1873-1875), o recrudescimento dos requisitos para o reconhecimento das ações como coletivas fez sua utilização minguar até perto do completo desaparecimento ${ }^{27}$.

Por outro lado, enquanto se observava esse declínio dos litígios coletivos na Inglaterra, essa modalidade de tutela de direitos passava a ser discutida com maior interesse na recém-independente colônia inglesa - os Estados Unidos da América -, que viria a se tornar o grande expoente da tutela dos interesses transindividuais nos séculos que se seguiram e até os dias de hoje. O sistema jurisdicional norte-americano, seguindo o modelo inglês, preservou a dualidade entre as jurisdições de equidade e de direito - até a edição das Rules of Civil Procedure em 1938, que extinguiu a diferenciação entre as referidas jurisdições -, tendo, no entanto, delegado ambas as jurisdições aos mesmos tribunais. Assim, ainda que essa organização tivesse diminuído a distância entre os dois sistemas, as ações coletivas continuaram intrinsecamente ligadas às regras da equidade ${ }^{28}$.

Alguns dos primeiros registros acerca de litígios coletivos nos Estados Unidos da América foram feitos por Joseph Story ${ }^{29}$ durante a primeira metade do século XIX. Desde essa época, já se fazia referência à importância de um sistema de tutela dos direitos coletivos para garantir o pleno acesso à justiça - não só por possibilitar o conhecimento de demandas - que, de outra forma, não seriam levadas ao judiciário, por terem valor

\footnotetext{
${ }^{25}$ Stephen Yeazell relata o caso conhecido por How vs. Tenants of Bromsgrove, ocorrido entre os séculos XV e XVI, em que o How (lord of the manor) - senhor do feudo de Bromsgrove - ajuíza demanda contra os arrendatários/inquilinos/servos (tenants), para garantir o seu direito de caçar livremente naquelas terras (" $a$ grant of free warren"). YEAZELL, Stephen. Group litigation and social context...Op. cit., p. 869.

${ }^{26}$ MENDES, Aluísio Gonçalves de Castro. Ações coletivas no direito comparado e nacional...Op. cit., p. 39.

${ }^{27}$ Segundo Aluíso Gonçalves de Castro Mendes, essa queda na utilização das ações coletivas deveu-se à mudança ideológica - que passou a priorizar o indivíduo em detrimento do grupo - o que levou a um recrudescimento dos tribunais ingleses quanto ao reconhecimento da presença dos requisitos necessários ao processamento de uma ação como coletiva, especialmente a existência de interesses comuns. Narra, para exemplificar essa afirmação, dois casos (Duke of Bedford vs. Ellis e Mark \& Co. Ltd. VS. Knight Steamship Co. $L t d$.) em que as ações foram rechaçadas por se entender que os membros da classe não compartilhavam de interesse comum (Ibid., p. 43-44).

${ }^{28}$ GIDI, Antonio. A Class Action como instrumento...Op. cit., p. 44-45.

${ }^{29}$ Renomado jurista norte-americano que integrou a Supreme Court daquele país entre os anos de 1811 a 1845 e estudou a fundo a jurisprudência e os procedimentos da jurisdição de equidade. Ver, nesse sentido, MENDES, Aluísio Gonçalves de Castro. Ação coletivas no direito comparado e nacional... Op. cit., p. 58.
} 
extremamente reduzido ao serem consideradas individualmente -, mas, também, por impedir a multiplicação de pleitos idênticos, reduzindo a sobrecarga dos tribunais (o que, desde então, já era preocupação presente na doutrina) ${ }^{30}$.

A primeira norma escrita sobre as ações coletivas nos Estados Unidos foi a Equit Rule 48 promulgada, ainda sob a jurisdição de equity, em 1842. Nela se previu a possibilidade da propositura de uma ação por um representante da classe (ou contra ele), sempre que fosse inviável a formação de litisconsórcio devido ao grande número de integrantes do grupo. Pontuava tal norma, entretanto, que, nesse caso, a decisão não poderia prejudicar os direitos e pretensões dos ausentes, uma vez que sempre se conservou em mente a necessidade de respeitar o devido processo legal (due process of law) ${ }^{31}$. Essa condição, em muito influenciada pelas ideias individualistas que permearam as discussões sociais e jurídicas a partir do século XVIII até a primeira metade do século XX, acabou limitando a utilização das Class Actions, posto que o alcance de uma decisão prolatada em tais demandas ficava restrito aos presentes, o que não a diferenciava substancialmente de outros institutos processuais tradicionais - como o próprio litisconsórcio ${ }^{32}$.

Faltava, portanto, uma regra que, a partir do reconhecimento que o representante da classe em juízo era capaz de defender os interesses dos integrantes dessa mesma classe inclusive daqueles que não participavam diretamente da relação jurídica processual -,

\footnotetext{
${ }^{30}$ Foi Stephen C. Yeazell quem transcreveu as palavras de Joseph Story sobre o assunto: "Story here encontered a central question of modern class action theory: whether the function of the class action is to consolidate suits that otherwise be brought (and thus to reduce the caseload of the judiciary) or to facilitate the bringing of suits that would otherwise not be brought because of the individual stakes are too small (and thus to increase the accessibility of adjudication). The first alternative aims at reducing existing litigation, the second at enabling potential litigation to occur; at some level the two stand in tension" (tradução livre: Story aqui encontrou uma questão central da teoria moderna da Class Action: se a função da ação coletiva é consolidar ações que seriam trazidas ao judiciário de outra forma (e, assim, reduzir o número de casos do judiciário) ou para facilitar a propositura de ações que não seriam ajuizadas em razão do pequeno benefício individual (e, assim, aumentar a acessibilidade à justiça). A primeira alternativa visa reduzir litígios existentes, a segundo a permitir litígio potencial). Ver: YEAZELL, Stephen. From medieval group litigation to the modern class action. New Haven: Yale University Press, 1987, p. 218.

31 "Where the parties on either side are very numerous, and cannot, without manifest inconvenience and oppressive delays, in the suit, be all brought before it, the court in its discretion may dispense with making all of them parties, and may proceed in the suit, having sufficient parties before it to represent all the adverse interests of the plaintiffs and the defendants in the suit properly before it. But in such cases the decree shall be without prejudice to the rights and claims of all absent parties" (tradução livre: Quando as partes de ambos os lados são muito numerosas, e não podem, sem inconveniente manifesto e atrasos opressivos, agir adequadamente no processo, o tribunal, a seu critério pode dispensar fazendo todos eles partes, e pode prosseguir na ação, tendo as partes suficientes antes de representar todos os interesses divergentes dos autores e dos réus no processo corretamente. Mas, nesses casos, o decreto deve ser sem prejuízo dos direitos e reivindicações de todas as partes ausentes). Ver: YEAZELL, Stephen. From medieval group litigation to the modern class action...Op. cit., p. 218.

${ }^{32}$ MENDES, Aluísio Gonçalves de Castro. Ações coletivas no direito comparado e nacional...Op.Cit., p. 62 .
} 
vinculasse todos eles ao resultado da demanda ${ }^{33}$. A evolução e a plena utilização das Class Actions nos Estados Unidos, portanto, dependiam do reconhecimento da representatividade adequada como requisito para o prosseguimento de uma ação como coletiva. Esse movimento começou com a jurisprudência norte-americana ainda durante a vigência da Equity Rule $48^{34}$, continuou com a revogação dessa norma pela Federal Equity Rule 38 de 1912 - que ampliava a eficácia da sentença das ações coletivas a terceiros que não integraram a relação jurídica processual-, atingindo seu ponto máximo com a promulgação das "Normas de Processo Civil Federal" (Rules of Civil Procedure), em 1938, as quais traziam em seu bojo a Rule 23, integralmente dedicada às Class Actions.

A edição das Rules of Civil Procedure marcou o fim da divisão entre as jurisdições de direito e de equidade nos Estados Unidos, de modo que as Class Actions passaram a ser utilizadas não mais apenas para pretensões de cunho declaratório, injuntivo ou mandamental - características do sistema de equity - como, também, para veicular pretensões indenizatórias $^{35}$. Assim, foram criadas três espécies de ações coletivas, com diferentes hipóteses de cabimento: as (i) true (puras); (ii) hybrid (híbridas) e (iii) spurious (espúrias).

As True Class Actions seriam cabíveis quando houvesse identidade absoluta dos interesses entre os membros do grupo, sendo a representação permitida para afastar um litisconsórcio de todos os membros quando este fosse inviável. Por esse motivo, a coisa julgada se estendia a todos os membros da classe representada - estivessem eles presentes ou não.

Já as Hybrid Class Actions se aplicariam em casos nos quais os membros da classe representada compartilhassem interesse em relação a determinado bem jurídico, que seria objeto da ação, de modo que a coisa julgada também vincularia todos os integrantes da classe.

\footnotetext{
${ }^{33}$ GIDI, Antonio. A Class Action como instrumento...Op. Cit., p. 46.

${ }^{34}$ Como exemplos dessa orientação vanguardista da jurisprudência, é possível citar o caso Smith vs. Swormstedt - de 1853 - em que a Supreme Court considerou adequada a representação de autores e réus e se pronunciou pela vinculação dos ausentes e, também, o caso American Steel \& Wire Co. vs. Wire Drawers' \& Die Markers' Union - de 1898 - em que o tribunal mencionou a falta de precedente mas, ainda assim, considerou que os líderes poderiam defender os interesses dos grevistas e os efeitos da decisão vinculariam a todos. Segundo Stephen C. Yeazell, esse precedente deixa claro que a aptidão para representar os interesses da classe não poderiam ser restritos a autorizações conferidas pelos integrantes do grupo ao representante eleito, mas deveriam ser aferidas pelas cortes e de acordo com as circunstâncias de cada caso concreto. Ver: YEAZELL, Stephen. From medieval group litigation to the modern class action...Op. Cit., p. 224.

${ }^{35}$ GIDI, Antonio. A Class Action como instrumento...Op. Cit., p. 47.
} 
Por fim, as Spurious Class Actions, a verdadeira inovação da Rule 23, serviriam para casos em que há uma pluralidade de interesses, mas decorrentes de uma questão comum de fato ou de direito que possibilitaria a utilização de uma via processual comum. Nesse último caso, não havia vinculação dos membros ausentes do grupo - os que quisessem ser atingidos pela decisão da ação coletiva deveriam optar por participar do litígio (opt in) - o que justificava a adoção do nome spurious (espúrias / falsas) para caracterizar esse tipo de ação ${ }^{36}$.

Com o tempo, entretanto, percebeu-se que o texto da Rule 23 de 1938 era demasiadamente complexo e confuso, especialmente no tocante à extensão dos efeitos da coisa julgada coletiva e à disciplina das spurious Class Actions que, em virtude da exigência de intervenção dos interessados e de distorções geradas por essa exigência, como a one way intervention ${ }^{37}$, acabou por se revelar um instrumento inadequado para a tutela de pretensões coletivas indenizatórias ${ }^{38}$. Essas peculiaridades determinaram a realização de uma profunda reforma na disciplina das Class Actions norte-americanas, partindo da reformulação do texto da Rule 23.

Essa reforma se deu no ano de 1966, pois era necessário estruturar o sistema de modo a permitir a veiculação de pretensões indenizatórias e garantir a extensão dos efeitos da coisa julgada, fossem estes favoráveis ou não ao grupo a todos seus integrantes, preservando o devido processo legal. Por esse motivo, deu-se ênfase à representatividade

\footnotetext{
${ }^{36}$ Sobre o assunto, ver: MENDES, Aluísio Gonçalves de Castro. Ações coletivas no direito comparado e nacional...Op. cit., p. 64-66; GIDI, Antonio. A Class Action como instrumento...Op. cit., p. 48-52; e GRINOVER, Ada Pellegrini. Da Class Actions for damages à ação de classe brasileira: os requisitos de admissibilidade. Revista de Processo, São Paulo: Ed. RT, ano 26, n.101, 2001, p. 12-13. Na mesma obra supracitada, Aluísio Gonçalves de Castro Mendes reúne alguns exemplos de utilização de cada um dos tipos de Class Actions: as ações puras eram usadas em casos de "quebra de confiança, resultante do esgotamento dos bens confiados à guarda de alguém, ajuizada por um dos beneficiários em face do administrador", as ações híbridas poderiam ser aplicáveis a causa "na qual acionistas pretendem se valer de seguro contra fraude, cuja indenização incidirá sobre um determinado fundo comum disponível e limitado para a cobertura de todos". Para as ações espúrias foi mais complexa a formulação de um exemplo, uma vez que ela não podia ser considerada como uma imposição da legislação, mas, somente, como um permissivo legal para o tratamento de direitos de origem comum.

${ }^{37} \mathrm{O}$ fenômeno da one-way intervention foi observado em alguns tribunais americanos, que permitiam a intervenção por parte dos membros do grupo (opt in) após a prolação de sentença que lhes fosse favorável. Essa prática foi alvo de diversas críticas porque, conquanto contribuísse para a efetivação da visão predominante na doutrina da época, que os ausentes não poderiam ser prejudicados por sentença desfavorável, muitos alegavam que ela dava azo a injustiças, uma vez que se concedia ao grupo todos os benefícios da vitória, sem os riscos inerentes à derrota em um processo judicial. Antonio Gidi, ao discorrer sobre esse ponto, assevera que outra crítica recorrente era quanto à inconsistência entre exigência de verificação da representatividade adequada dos membros ausentes e, quando da prolação da sentença, impedir que a coisa julgada vinculasse a todos os representados. Aventa, ainda, que o sistema da one-way intervention em muito se assemelha a uma versão primitiva da coisa julgada secundum eventum litis adotada no processo coletivo brasileiro. Ver: GIDI, Antonio. A Class Action como instrumento...Op. cit., p. 54.

${ }^{38}$ Ibid., p. 56.
} 
adequada, ressaltando a importância da aferição desta para essa nova realidade ${ }^{39}$. Procedeu-se, ainda, uma reformulação das categorias de Class Actions que, conquanto continuassem sendo três, passaram a ser divididas por um critério mais pragmático, levando em conta a existência de interesses comuns entre os membros do grupo ${ }^{40}$. A Rule 23 passou por algumas reformas posteriores, entre elas a mais recente foi a Class Action Fairness Act (CAFA), que implementou diversas mudanças, com o objetivo principal de evitar abusos dos demandantes e federalizar jurisdição sobre as ações coletivas que envolvessem mais de um Estado ou tivessem abrangência nacional.

Seja como for, a Rule 23 vigora, desde a década de 60, sem grandes alterações em seu texto legal, de modo que a reforma intentada em 1966, aliada ao momento histórico de expansão e massificação das relações jurídicas e de consumo na sociedade norteamericana, transformou as Class Actions - até então consideradas como um instrumento útil de tutela de direitos, mas um tanto complicado e restrito -, em um poderoso instrumento de cunho político e jurídico, apto a veicular pretensões que, até então, não eram levadas a juízo (small claims), promovendo efetivo acesso à justiça ${ }^{41}$.

Em termos estruturais, a Rule 23 passou a prever os requisitos para a certificação de uma demanda como Class Actions:

(i) a existência de uma classe identificável - Rule 23 (a);

(ii) numerosidade dos integrantes da classe (numerosity), suficiente para inviabilizar o litisconsórcio - Rule 23 (a) (1);

(iii) existência de questões comuns de fato ou de direito - Rule 23 (a) (2);

(iv) identidade de pretensões entre o representante e a classe - Rule 23 (a) (3);

(v) representatividade adequada - Rule $23\left(\right.$ a) $(4)^{42}$.

O procedimento de certificação de uma demanda como Class Action consiste, exatamente, na verificação, feita pelo juiz, da presença desses pré-requisitos. A ausência de

\footnotetext{
${ }^{39}$ MENDES, Aluísio Gonçalves de Castro. Ação coletivas no direito comparado e nacional...Op. cit., p. 68.

${ }^{40}$ GIDI, Antonio. A Class Action como instrumento...Op. cit., p. 57.

${ }^{41}$ Ibid., p. 60.

42 (a) Prerequisites. One or more members of a class may sue or be sued as representative parties on behalf of all members only if: (1) the class is so numerous that joinder of all members is impracticable, (2) there are questions of law or fact common to the class, (3) the claims or defenses of the representative parties are typical of the claims or defenses of the class; and (4) the representative parties will fairly and adequately protect the interests of the class. (tradução livre: (a) Pré-requisitos. Um ou mais membros da classe pode acionar ou ser acionado como parte representativa de todos os membro apenas se: (1) a classe for tão numerosa a ponto de ser impraticável unir todos os membros; (2) houver questões legais ou fáticas comuns a toda a classe; (3) os pleitos ou defesa da parte representativa forem típicos de pleitos ou defesa de classe; (4) a parte representativa defenderá de forma justa e adequada os interesses da classe.
} 
qualquer um deles poderá determinar que a ação prossiga, mas não como ação coletiva; sendo certo que cada tipo diferente de Class Action poderá determinar mais ou menos atenção para cada um dos requisitos de certificação ${ }^{43}$.

De acordo com essa nova regulamentação, as Class Actions foram segmentadas ainda em dois tipos distintos - as obrigatórias (mandatory Class Actions) e as não obrigatórias (not mandatory Class Actions), todas elas previstas no artigo (b) da Rule 23.

As ações descritas nos itens (b1), (a) e (b) referem-se às ações que, caso não propostas na forma coletiva, prejudicariam os interesses dos réus ou dos autores. Já aquelas descritas no item (b2) contemplam as obrigações de fazer ou não fazer, bem como as pretensões declaratórias ${ }^{44}$. Por se tratarem de ações coletivas obrigatórias, seu resultado necessariamente vincula todos os integrantes da classe.

A terceira categoria, descrita pelo inciso (b3) da Rule 23, trata das ações coletivas não obrigatórias (not mandatory) e que se referem basicamente à reparação de danos individualmente sofridos - motivo pelo qual ficaram conhecidas como Class Actions for damages $^{45}$ e 46 . Para o processamento dessas últimas ações, é preciso verificar - além dos

${ }^{43}$ GRINOVER, Ada Pellegrini (et. alli). Os processos coletivos nos países de Civil Law e Common Law uma análise de direito comparado. São Paulo: Ed. RT, 2008, p. 280-284. Ver, também, GIDI. Antonio. A Class Action como instrumento...Op. cit., p. 67-70.

44 "A class action may be maintained if Rule 23(a) is satisfied and if:(1) prosecuting separate actions by or against individual class members would create a risk of:(A) inconsistent or varying adjudications with respect to individual class members that would establish incompatible standards of conduct for the party opposing the class; or $(B)$ adjudications with respect to individual class members that, as a practical matter, would be dispositive of the interests of the other members not parties to the individual adjudications or would substantially impair or impede their ability to protect their interests; (2) the party opposing the class has acted or refused to act on grounds that apply generally to the class, so that final injunctive relief or corresponding declaratory relief is appropriate respecting the class as a whole.". (tradução livre: a Class Action pode ser mantida se a Rule 23: (a) estiver satisfeita e se: (1) processar separadamente as ações a favor ou contra membros individuais da classe pudesse criar um risco de: (A) decisões inconsistentes ou variadas, respeitando os membros individuais da classe mas criando padrões diversos de conduta para a parte que se opõe à classe; ou (B) decisões que respeitem os membros individuais da classe que, na prática, se oporiam aos interesses de outros membros da classe não membros ou impediriam sua manifestação por meio de ação individual; (2) a parte que se opõe a classe tenha agido ou se recusado a agir nos termos que se aplicam geralmente à classe, para que a medida de injução ou medida declaratória correspondente respeite a classe como um todo). Sobre o assunto, ver GRINOVER, Ada Pellegrini. Da Class Actions for damages à ação de classe brasileira...Op. cit., p. 14.

${ }^{45}$ A class action may be maintained if Rule 23(a) is satisfied and if:(3) the court finds that the questions of law or fact common to class members predominate over any questions affecting only individual members, and that a class action is superior to other available methods for fairly and efficiently adjudicating the controversy. (Uma Class Action pode ser mantida se a Rule 23 estiver satisfeita e se: (3) o tribunal entender que as questões de fato ou de direito comuns aos membros da classe predominam sobre as questões que afetam os membros individualmente, e que a Class Action é um método superior aos outros disponíveis para resolver a controvérsia de forma eficiente e justa).

${ }^{46}$ Alguns autores comparam as espécies de Class Actions descritas na Rule 23 com as vias de tutela dos direitos transindividuais no Brasil. As mandatory class actions corresponderiam às ações relativas à tutela dos direitos difusos e coletivos, enquanto as class actions for damages seriam as ações voltadas para a tutela dos interesses individuais homogêneos. Nesse sentido ver: GRINOVER, Ada Pellegrini. Da Class Actions 
pré-requisitos de certificação apontados anteriormente - se as questões de fato e de direito comuns superam as questões individuais e se a tutela coletiva, de fato, será mais efetiva, em termos de justiça e eficácia da sentença, que a ação individual ${ }^{47}$. Nessas ações, os integrantes da classe podem optar por não se vincular ao resultado da demanda, exercendo o direito de retirada (opt out).

É certo que a disciplina das Class Actions no sistema de Common law, especialmente nos Estados Unidos onde alcançou inequívoca notoriedade, está em constante evolução, seja em virtude da prática diária dos tribunais, seja devido aos reiterados estudos realizados por juristas norte-americanos, com o objetivo de propor alterações da Rule 23. Nas palavras de Antonio Gidi, a principal meta é, também, o principal desafio: "[...] conceber uma reforma que, mantendo intactos os aspectos saudáveis das class actions, consiga extirpar os problemas encontrados na sua prática"48. Problemas estes que, conforme apontados pelo mesmo autor, relacionam-se, em grande escala, à má utilização dos instrumentos de tutela coletiva mediante a adoção de práticas abusivas pelas partes e por seus advogados.

De qualquer forma, a doutrina e a jurisprudência norte-americanas reconhecem a Class Action como poderoso instrumento de articulação política e social, permitindo a veiculação de pretensões da sociedade civil contra o poder institucionalizado - exercido pelo Estado ou pelos agentes detentores de poder econômico ${ }^{49}$. A bem sucedida experiência dos Estados Unidos da América nesse campo acabou por repercutir, no final do século XX e início do século XXI, nos ordenamentos jurídicos de outros países, como a Inglaterra - onde, desde o final do século XVIII, as ações coletivas se encontravam em desuso ${ }^{50}$.

Feito este panorama da evolução histórica da tutela dos direitos transindividuais no sistema de Common law - tomando como pontos de referência os dois países mais representativos que adotam essa sistemática -, importa verificar de que forma o ideário dos direitos coletivos foi transposto para o sistema de Civil law e como se desenvolveu e se

for damages à ação de classe brasileira...Op. cit., p. 14. Ver também "Ações Coletivas: premissas para comparação com o sistema norte-americano" (SALLES, Carlos Alberto (et alli). Processos Coletivos e Tutela Ambiental. Santos: Ed. Unisantos, 2006, p. 28-29).

${ }^{47}$ GRINOVER, Ada Pellegrini. Da Class Actions for damages à ação de classe brasileira...Op. cit., p. 15.

${ }^{48}$ GIDI, Antonio. A Class Action como instrumento...Op. Cit., p. 65.

${ }^{49}$ Ibid., p. 65-66.

${ }^{50}$ MENDES, Aluísio Gonçalves de Castro. Ações coletivas no direito comparado e nacional...Op.cit., p. 48-56. 
adaptou às peculiaridades dos ordenamentos jurídicos de diversos países, entre eles o Brasil.

\subsection{ORDENAMENTOS JURÍDICOS DO SISTEMA DE CIVIL LAW}

Os estudos acerca dos interesses coletivos e de suas formas de tutelas adentram os países que adotam o sistema de Civil Law por meio das discussões doutrinárias travadas na Itália, na primeira metade da década de 1970. Os congressos realizados em Pavia (1974) e Salerno (1975) reuniram nomes como Vittorio Denti, Mauro Capelletti, Andrea Proto Pisani, Vincenzo Vigoriti, Nicolò Trocker e Michele Taruffo que - com vistas à experiência dos países de Common $\operatorname{Law}^{51}$ e a inegável importância política a que foram alçadas as Class Actions no direito norte-americano nas décadas de 1950 e $1960^{52}$, bem como as decisões prolatadas na Itália sobre o tema ${ }^{53}$ - passaram a teorizar sobre as características e a natureza dos interesses transidividuais, de que forma poderiam ser tutelados e, ainda, que benefícios essa mudança de foco, do processo individual para o processo coletivo, poderia trazer à realização da justiça.

As ideias trazidas à luz por esses doutrinadores (especialmente por Mauro Cappelletti em seu trabalho "Formações sociais e interesses coletivos diante da justiça civil”), que apontavam para a superação da dicotomia público/privado em uma sociedade marcada por relações massificadas e para a necessidade de que o processo civil se adaptasse a essa nova realidade ${ }^{54}$, influenciaram sobremaneira os juristas brasileiros, os

\footnotetext{
${ }^{51}$ GRINOVER, Ada Pellegrini. Significado social, político e jurídico da tutela...Op. cit., p. 9..

52 Além da já citada reforma na Rule 23 em 1966, a decisão no caso Brown vs. Board of Education foi uma clara demonstração da importância política da defesa em juízo dos direitos transindividuais. A Class Action proposta por Brown contra o Conselho Educacional de Topeka (Kansas) acabou por chegar à Suprema Corte dos Estados Unidos (na época sob a presidência de Earl Warren) onde, em 1954, foi declarada a inconstitucionalidade da segregação de estudantes negros e brancos em escolas diversas. Disponível em http://www.law.cornell.edu/supct/html/historics/USSC_CR_0347_0483_ZO.html. Acessado em 21jun.2011.

${ }^{53}$ Em 1973, um ano antes do Congresso de Pavia, o Conselho de Estado da Itália reconheceu a legitimidade da associação ambientalista Italia Nostra para impugnar ato da província de Trento que autorizava a construção de uma autoestrada nas imediações do lago Tovel. Na época, parecia ser um precedente importante na direção de uma consolidação da existência de direitos difusos e da necessidade de instrumentos novos para sua tutela. Nesse sentido, ver MENDES, Aluísio Gonçalves de Castro. Ação coletivas no direito comparado e nacional...Op.Cit., p. 97 e VIGORITI, Vincenzo. Metodi e prospettive di uma recente giurisprudenza in tema di interessi diffusi e collettivi. Giurisprudenza Italiana, n.305, IV, 1980, p. 305.

${ }^{54}$ Nesse trabalho, assevera Mauro Cappelletti: "Não é necessário ser sociólogo de profissão para reconhecer que a sociedade (podemos usar a ambiciosa palavra: civilização?) na qual vivemos é uma sociedade ou civilização de produção em massa, de troca e de consumo de massa, bem como de conflitos ou conflituosidades de massa (em matéria de trabalho, de relações entre classes sociais, entre raças e religiões, etc.). Daí deriva que também as situações de vida, que o Direito deve regular, são tornadas sempre mais complexas, enquanto, por sua vez, a tutela jurisdicional - a "Justiça" - será invocada não mais somente
} 
quais passaram a discutir a possibilidade de estruturar um sistema de defesa dos direitos difusos e coletivos no país.

\subsubsection{Evolução da tutela coletiva de direitos no Brasil}

Conquanto o atual microssistema de tutela dos interesses transindividuais no Brasil tenha se desenvolvido, fundamentalmente, com base nos ideais de ampliação do acesso à justiça, discutidos na década de 70 na Itália, - resultantes de reflexões de renomados processualistas, conforme anteriormente destacado -, é certo que, antes disso, as bases desse sistema já existiam.

Como em vários outros países que adotam o sistema de Civil law, especialmente a Itália, como será visto adiante, o Brasil pôde observar um primeiro desenvolvimento da tutela dos direitos coletivos no âmbito do direito trabalhista e na atividade dos sindicatos ao defenderem os direitos dos integrantes de determinada categoria. A Consolidação das Leis do Trabalho (CLT) prevê, desde sua entrada em vigor no ano de 1946, a possibilidade da agregação de pessoas de uma mesma categoria - e.g. trabalhadores, empregadores, profissionais liberais - com o objetivo de defender os direitos daquela classe. Entre as prerrogativas dos sindicatos, previstas desde então, está a representação perante autoridade administrativa ou judiciária dos interesses da categoria (Artigo 513, “a”, CLT). E, apesar do fato que, nesse primeiro momento, a atuação sindical ainda estivesse muito atrelada ao poder do Estado, é claro que se tratou de um início da positivação da possibilidade de tutela de direitos de toda uma coletividade ${ }^{55}$.

Também já existia a Lei $n^{\circ} 1.134 / 1950$ - que previa a possibilidade de associações de classe agirem, em juízo ou na esfera administrativa, visando representar coletiva ou individualmente seus associados - e a Lei $\mathrm{n}^{\circ}$ 4.215/1963, o antigo estatuto da Ordem dos Advogados do Brasil (OAB) - que contava com a possibilidade da entidade de classe representar os interesses dos advogados, em juízo e fora dele, em temas relacionados ao exercício da profissão (artigo $1^{\circ}$, parágrafo único da referida lei $)^{56}$.

contra violações de caráter individual, sempre mais freqüente contra violações de caráter essencialmente coletivo, enquanto envolvem grupos, classes e coletividades. Trata-se, em outras palavras, de "violações de massa" (CAPPELLETTI, Mauro. Formações sociais e interesses coletivos...Op.cit., p. 130).

${ }^{55}$ MARTINS, Sérgio Pinto. Direito do Trabalho. 19. ed. São Paulo: Ed. Atlas: 2004, p. 693-714.

${ }^{56}$ DINAMARCO, Pedro. Ação Civil Pública. São Paulo: Saraiva, 2001, p.36. 
Entretanto, com a entrada em vigor da Lei $n^{\circ} 4.717$ em 29 de junho de 1965 denominada Lei da Ação Popular - os contornos da nova disciplina começam a se tornar mais nítidos. Essa lei, que permanece em vigor até os dias de hoje com poucas alterações, passa a prever a possibilidade de qualquer cidadão ajuizar ação popular, visando a declaração de nulidade ou a anulação de atos lesivos ao patrimônio público, perpetrados por autoridades públicas ${ }^{57}$. Em 1977, uma alteração no texto original da Lei da Ação Popular, introduzida pela Lei $n^{\circ} 6.513 / 1977$, especificou o que viria a ser considerado patrimônio público - no caso, os bens e direitos de valor econômico, artístico, estético, histórico ou turístico. Trata-se de ação coletiva na medida em que, através dela, se podem alcançar dimensões metaindividuais, ou, nas palavras de Rodolfo de Camargo Mancuso:

[...] quando algum nível do universo coletivo será atingido no momento em que transitar em julgado a decisão que a acolhe, espraiando assim os seus efeitos, seja na notável dimensão dos interesses difusos, ou ao interior de certos corpos intercalares onde se aglutinam interesses coletivos, ou ainda no âmbito de certos grupos ocasionalmente constituídos em função de uma origem comum $[\ldots]^{58}$.

No ano de 1981, foi positivada a Lei $\mathrm{n}^{\circ}$ 6.938, sobre a Política Nacional do Meio Ambiente, legitimando o Ministério Público a propositura de ações de responsabilidade civil e penal por danos ambientais. Ada Pellegrini Grinover aponta que a limitação da legitimidade ativa e a ausência de regulamentação de temas relevantes, - como a extensão da coisa julgada -, pela referida lei ambiental, resultaram na propositura de uma série de ações populares com o objetivo de tutelar direitos difusos ligados ao meio ambiente. Essa via processual, entretanto, era muito limitada, uma vez que seu exercício ficava restrito a ilegalidades provenientes de ações ou omissões do Poder Público (ou de particulares que, de alguma forma, estivessem ligados à atuação estatal $)^{59}$.

A necessidade de ampliar o espectro de proteção dos interesses transindividuais levou os estudiosos do tema a discutir a possibilidade de uma lei que se prestasse a uma

\footnotetext{
${ }^{57}$ Art. $1^{\circ}$ Qualquer cidadão será parte legítima para pleitear a anulação ou a declaração de nulidade de atos lesivos ao patrimônio da União, do Distrito Federal, dos Estados, dos Municípios, de entidades autárquicas, de sociedades de economia mista (Constituição, art. 141, § 38), de sociedades mútuas de seguro nas quais a União represente os segurados ausentes, de empresas públicas, de serviços sociais autônomos, de instituições ou fundações para cuja criação ou custeio o tesouro público haja concorrido ou concorra com mais de cinquienta por cento do patrimônio ou da receita ânua, de empresas incorporadas ao patrimônio da União, do Distrito Federal, dos Estados e dos Municípios, e de quaisquer pessoas jurídicas ou entidades subvencionadas pelos cofres públicos.

${ }^{58}$ MANCUSO, Rodolfo de Camargo. Ação Popular - proteção do erário, do patrimônio público, da moralidade administrativa e do meio ambiente. 6. ed. São Paulo: Ed. RT, 2008, p. 42.

${ }^{59}$ GRINOVER, Ada Pellegrini. Significado social, político e jurídico da tutela...Op. cit., p. 10-11.
} 
tutela mais abrangente, voltada em especial aos direitos difusos ${ }^{60}$. Partindo disso, foram elaborados dois anteprojetos de lei - um pelos juristas Ada Pellegrini Grinover, Cândido Rangel Dinamarco, Kazuo Watanabe e Waldemar Mariz de Oliveira Junior, e outro pelos integrantes do Ministério Público do Estado de São Paulo. Acabou por ser aprovado o anteprojeto apresentado pelos membros do parquet paulista, resultando na Lei da Ação Civil Pública (Lei no $7.347 / 1985)^{61}$.

Esse diploma legal, em sua gênese nos idos do ano de 1985, regulava as ações de responsabilidade por danos causados ao meio ambiente, ao consumidor e a bens e direitos de valor artístico, estético, histórico, turístico e paisagístico. Não havia menção, portanto, à tutela de direitos difusos e coletivos - denominação que apareceu, pela primeira vez, na Constituição Federal de 1988 (artigo 129, III e $§ 1^{\circ}$ ) ao tratar das funções institucionais do Ministério Público. A Constituição positivou, ainda, outras formas de tutela coletiva de direitos, como o mandado de segurança coletivo (artigo $5^{\circ}$, LXX), tendo destacado a legitimidade das associações, partidos políticos, e sindicatos para sua impetração e, ainda, para a representação de seus integrantes (artigos $5^{\circ}$, XXI e $8^{\circ}$, III $)^{62}$.

Os direitos difusos e coletivos, no entanto, só vieram a ser detalhados, especificados e delimitados em nossa legislação com a aprovação do Código de Defesa do Consumidor $^{63}$ (que entrou em vigor no ano de 1991,), tendo definido de forma sistematizada e didática os direitos difusos e coletivos e, além disso, criado a categoria dos direitos individuais homogêneos, que acabou por ampliar o âmbito de incidência da Lei da Ação Civil Pública, a qual sofreu várias alterações em virtude da legislação consumerista

${ }^{60}$ Relata Maximilian Fierro Paschoal que “[...] em 1982 ocorreu o famoso seminário sobre a tutela dos interesses difusos, coordenado pela professora Ada Pellegrini Grinover. Ao final dos debates restou decidido que uma comissão iria ser formada para elaborar um anteprojeto de lei relativo à proteção de interesses difusos". (PASCHOAL, Maximilian Fierro. A representatividade adequada na ação coletiva brasileira (lei da ação civil pública e código de defesa do consumidor). 2006. 342f. Dissertação (Mestrado em Direito Processual Civil) - Faculdade de Direito da Universidade de São Paulo, sob a orientação do Professor Kazuo Watanabe, São Paulo, 2006, p.76-77).

${ }^{61}$ É certo que a aprovação do texto proposto pelo Ministério Público teve uma série de implicações de cunho político e social, uma vez que o anteprojeto veio permeado de ideias referentes à priorização do Ministério Público como defensor dos direitos difusos. Não foram contempladas, por esse motivo, matérias que constavam do anteprojeto apresentado pelos juristas citados, entre eles a verificação da representatividade adequada como componente da atribuição de legitimidade ativa ao autor coletivo. Sobre o assunto ver Sobre o assunto ver PASCHOAL, Maximilian Fierro. A representatividade adequada na ação coletiva brasileira...Op. cit., p. 77; e ARANTES, Rogério Bastos. Ministério Público e Política no Brasil. São Paulo: Ed. Sumaré, 2002, p. 54.

${ }^{62}$ GRINOVER, Ada Pellegrini. Significado social, político e jurídico da tutela...Op. cit., p. 11.

${ }^{63}$ Foi elaborado o Código de Defesa do Consumidor com o objetivo de dar cumprimento ao que fora determinado no artigo 48 do Ato das Disposições Constitucionais Transitórias, da Constituição promulgada em 1988, que previa expressamente que o Congresso Nacional, dentro de cento e vinte dias da promulgação da Constituição, elaboraria um código de defesa do consumidor. Nesse sentido, ver Nesse sentido, ver MENDES, Aluísio Gonçalves de Castro. Ação coletivas no direito comparado e nacional...Op. cit., p. 196. 
sobre o tema. Esse diploma legal, conquanto tenha sido idealizado para a proteção dos consumidores, trouxe consigo diversas regras de direito processual que passaram a ser aplicadas às ações coletivas sobre todos os temas. Compôs-se, assim, o chamado microssistema de processos coletivos brasileiro.

No parágrafo único do artigo 81 do Código de Defesa do Consumidor ${ }^{64}$ procurouse definir as categorias de interesses transindividuais passíveis de tutela pela via das ações coletivas. A doutrina pátria destrinchou esses conceitos e chegou a um denominador comum sobre cada um desses interesses, tendo ficado definidos da seguinte forma: (i) direitos difusos são aqueles cujos titulares são indeterminados e indetermináveis, e o bem jurídico é indivisível; (ii) direitos coletivos, de outra feita, são aqueles em que o objeto também é indivisível, mas os titulares do direito são uma coletividade ligada entre si - ou com a parte contrária - por uma relação jurídica base; e por fim, os (iii) direitos individuais homogêneos, que são aqueles decorrentes de uma origem comum - são divisíveis e seus titulares são plenamente identificáveis, entretanto a lei faculta a tutela coletiva em razão das características comuns ${ }^{65}$.

\footnotetext{
${ }^{64}$ Art. 81. A defesa dos interesses e direitos dos consumidores e das vítimas poderá ser exercida em juízo individualmente, ou a título coletivo. Parágrafo único. A defesa coletiva será exercida quando se tratar de: I interesses ou direitos difusos, assim entendidos, para efeitos deste código, os transindividuais, de natureza indivisível, de que sejam titulares pessoas indeterminadas e ligadas por circunstâncias de fato; II - interesses ou direitos coletivos, assim entendidos, para efeitos deste código, os transindividuais, de natureza indivisível de que seja titular grupo, categoria ou classe de pessoas ligadas entre si ou com a parte contrária por uma relação jurídica base; III - interesses ou direitos individuais homogêneos, assim entendidos os decorrentes de origem comum.

65 "Na conceituação dos interesses ou direitos "difusos", optou-se pelo critério da indeterminação dos titulares e da inexistência entre eles de relação jurídica base, no aspecto subjetivo, e pela indivisibilidade do bem jurídico, no aspecto objetivo. [...] No campo da relação de consumo, podem ser figurados os seguintes exemplos: a) publicidade enganosa ou abusiva, veiculada por meio da imprensa falada, escrita ou televisionada, afetando uma multidão incalculável de pessoas, sem que entre elas exista uma relação-base. [...] Os interesses ou direitos 'coletivos' foram conceituados como 'os transindividuais de natureza indivisível de que seja titular grupo, categoria ou classe de pessoas ligadas entre si ou com a parte contrária por uma relação jurídica base" (Art. 81, parágrafo único, nII). Essa relação jurídica base é a preexistente à lesão ou ameaça de lesão do interesse ou direito do grupo, categoria ou classe de pessoas. Não a relação jurídica nascida da própria lesão ou ameaça de lesão. Os interesses ou direitos dos contribuintes [...] do imposto de renda constituem um bom exemplo. [...] O inc. III do parágrafo único do art. 81 conceitua os interesses ou direitos "individuais homogêneos" como "os decorrentes de origem comum", permitindo a tutela deles a título coletivo. A homogeneidade e a origem comum são, portanto, os requisitos para o tratamento coletivo dos direitos individuais. [...] A origem comum pode ser de fato ou de direito, a expressão não significa, necessariamente, uma unidade factual e temporal. [...] a origem comum (causa) pode ser próxima ou remota. Próxima, ou imediata, do caso da queda de um avião, que vitimou diversas pessoas; ou remota, mediata, como no caso de um dano à saúde, imputado a um produto potencialmente nocivo, que pode ter tido como causa próxima as condições pessoais ou o uso inadequado do produto. Quanto mais remota for a causa, menos homogêneos serão os direitos". (WATANABE, Kazuo. Código de Defesa do Consumidor: comentado pelos autores do anteprojeto, Ada Pelegrini Grinover [et. al.]. vol.II. 10. ed. Rio de Janeiro: Forense Universitária, 2011, p. 71-82.
} 
Nota-se que nos direitos difusos e coletivos é nítido o caráter transindividual, sendo impossível mensurar o impacto individual da ameaça ou da lesão a tais interesses ${ }^{66}$. Nos direitos individuais homogêneos, entretanto, ocorre o inverso - uma vez que se tratam de danos experimentados individualmente e que, por sua origem comum e sua homogeneidade, podem ser tutelados de forma coletiva. José Carlos Barbosa Moreira observa que os interesses difusos e coletivos são ontologicamente transindividuais, enquanto os interesses individuais homogêneos se apresentam como coletivos apenas acidentalmente $^{67}$. Ainda que não exista consenso absoluto na doutrina sobre essa classificação e sobre os critérios utilizados para proceder essa divisão ${ }^{68}$, a maior parte dos estudiosos do tema em nosso país a adotou - motivo pelo qual será esta a linha seguida no presente estudo.

Outras leis foram editadas, compondo o quadro da tutela jurisdicional dos direitos metaindividuais no Brasil. Algumas delas foram a Lei de responsabilidade pelos danos causados aos investidores do mercado de valores mobiliários (Lei no 7.913/1989) ${ }^{69}$ e a Lei Antitruste (Lei $\mathrm{n}^{\circ}$ 8.884/1994). Ambas, em alguma medida, previram regras processuais que se prestavam à proteção de direitos difusos coletivos e individuais homogêneos como a possibilidade de reparação de danos materiais e morais decorrentes de infração à ordem econômica ou à economia popular ${ }^{70}$.

A história do desenvolvimento do sistema brasileiro de tutela dos interesses transindividuais, entretanto, não foi livre de reveses. Ao longo das últimas duas décadas, entraram em vigor diversas leis que impuseram restrições tanto ao cabimento das ações coletivas contra atos do Poder Público - como a Medida Provisória n ${ }^{\circ}$ 2.180/2001, que alterou o artigo $1^{\circ}$ da Lei $n^{\circ} 7.347 / 1985$, determinando o não cabimento de ações civis públicas para veicular pretensões que envolvam tributos, contribuições previdenciárias ou

\footnotetext{
${ }^{66}$ PASCHOAL, Maximilian Fierro. A representatividade adequada na ação coletiva brasileira...Op. cit., p. 79.

${ }^{67}$ GRINOVER, Ada Pellegrini. Significado social, político e jurídico da tutela...Op. cit., p. 12.

${ }^{68}$ Nesse sentido, sobre a denominação considerada errônea dos direitos difusos ver SALOMÃO FILHO, Calixto. Função Social do Contrato: primeiras anotações. Revista de Direito Mercantil, Industrial, econômico e financeiro. São Paulo: Malheiros, n.32, ano XLII, p. 7-24, out/dez.2003.

${ }^{69}$ Essa lei prevê que os danos causados aos investidores em razão de operações fraudulentas e outros tipo de manipulação de preços no mercado de valores mobiliários deverão ser ressarcidos, cada investidor recebendo na medida do seu prejuízo. A ação própria para o pedido de ressarcimento é a ação civil pública, nos termos expostos da Lei $\mathrm{n}^{\circ} 7.347 / 1985$.

${ }^{70}$ MENDES, Aluísio Gonçalves de Castro. Ações coletivas no direito comparado e nacional...Op. cit., p. 197.
} 
FGTS $^{71}$-, quanto no que diz respeito a extensão dos efeitos das decisões prolatadas nas ações coletivas - a exemplo da Lei $n^{\circ}$ 9.494/1997, que alterou o artigo 16 da Lei $n^{\circ}$ $7.347 / 1985$, para fazer constar a limitação territorial da coisa julgada ${ }^{72}$.

Vê-se, pois, que as ações coletivas no Brasil são disciplinadas, até os dias de hoje, por leis esparsas - como as que foram citadas acima -, de modo que o sistema carece de uma sistematização e uma unidade orgânica interna, visto que o Código de Processo Civil, mesmo tendo passado por diversas reformas após a positivação dos meios de tutela dos interesses transindividuais, nunca veio a contemplar a matéria. Em vista disso, cresceu no Brasil, após o amadurecimento das ideias e dos conceitos ligados aos processos coletivos durante a década de 1990, um movimento codificador, com o qual vieram os anteprojetos de Código de Processos Coletivos no Brasil e o Projeto da Nova Lei da Ação Civil Pública.

Entre os anos de 2004 e 2006 foram desenvolvidas nos cursos de pós-graduação da Faculdade de Direito da Universidade de São Paulo (USP) e nas faculdades de Direito da Universidade Estadual do Rio de Janeiro (UERJ) e Estácio de Sá duas versões de anteprojeto do Código de Processos Coletivos, as quais foram apresentadas ao Ministério da Justiça - o que acabou motivando a criação, no ano de 2008, de uma Comissão Especial, composta por juristas especialistas, além de membros da magistratura, do Ministério Público e da advocacia, com o objetivo de aprimorar e modernizar a legislação material e processual sobre os direitos difusos, coletivos e também sobre os individuais homogêneos ${ }^{73}$. Paralelamente aos códigos de processo coletivo, em 2009, passou-se a

\footnotetext{
71 “Art. 16. A sentença civil fará coisa julgada erga omnes, nos limites da competência territorial do órgão prolator, exceto se o pedido for julgado improcedente por insuficiência de provas, hipótese em que qualquer legitimado poderá intentar outra ação com idêntico fundamento, valendo-se de nova prova." Art. 2o-A. A sentença civil prolatada em ação de caráter coletivo proposta por entidade associativa, na defesa dos interesses e direitos dos seus associados, abrangerá apenas os substituídos que tenham, na data da propositura da ação, domicílio no âmbito da competência territorial do órgão prolator. (Incluído pela Medida provisória $\mathrm{n}^{\mathrm{o}} 2.180-35$, de 2001).

Parágrafo único. Nas ações coletivas propostas contra a União, os Estados, o Distrito Federal, os Municípios e suas autarquias e fundações, a petição inicial deverá obrigatoriamente estar instruída com a ata da assembléia da entidade associativa que a autorizou, acompanhada da relação nominal dos seus associados e indicação dos respectivos endereços.

${ }^{72}$ Parágrafo único. Não será cabível ação civil pública para veicular pretensões que envolvam tributos, contribuições previdenciárias, o Fundo de Garantia do Tempo de Serviço - FGTS ou outros fundos de natureza institucional cujos beneficiários podem ser individualmente determinados."

${ }^{73}$ Descreve Aluísio Gonçalves de Castro Mendes que, além dele próprio, a Comissão Especial foi composta de nomes como Rogério Favretto (Secretário da Reforma do Judiciário), Luiz Manoel Gomes Jr., Ada Pellegrini Grinover, Athos Gusmão Carneiro, Antonio Carlos de Oliveira Gidi, Consuelo Yatsuda Moromizato Yoshida, Elton Venturi, Gregório Assagra de Almeida, entre muitos outros, contando com representantes da Casa Civil da Presidência da República, da Advocacia Geral da União, Ministério da Fazenda, Secretarias de Assuntos Legislativos, Direito Econômico e Consultoria Jurídica do Ministério da Justiça ((MENDES, Aluísio Gonçalves de Castro. Ações coletivas no direito comparado e nacional...Op.cit., p. 201). Ver, ainda, sobre o assunto, a exposição de motivos do Anteprojeto do Código
} 
discutir o Projeto de Lei $n^{\circ} 5.139 / 2009$, que surgiu com o objetivo de reformar a lei da Ação Civil Pública e acabou se transformando em uma proposta de unificação da sistemática das ações coletivas. Esse projeto de lei, no entanto, foi rejeitado pela Câmara dos Deputados em 17 de março de 2010, enquanto os dois anteprojetos de Código de Processos Coletivos continuam pendentes de análise. Até o momento, portanto, as tentativas de codificação e sistematização dos direitos e interesses transindividuais e dos seus instrumentos de tutela foram frustradas.

Em nenhum dos diplomas legais vigentes foram positivados critérios para a aferição da representatividade adequada dos litigantes, particularmente dos autores das demandas coletivas. Também não foi prevista a possibilidade do juiz aferir a representatividade dos autores no caso concreto. E essa possibilidade, ainda que ausente a previsão legal, - além das reiteradas tentativas de positivação -, será o ponto central deste estudo, cuja análise estará em capítulo próprio ${ }^{74}$.

Não obstante, considerados os avanços e retrocessos experimentados pela legislação pátria acerca do tema, é possível dizer que o Brasil está na vanguarda da tutela dos interesses difusos, coletivos e individuais homogêneos entre os países do sistema de Civil Law, tendo exercido influência em diversos ordenamentos jurídicos da América Latina $^{75}$.

Movimento análogo também foi observado nos ordenamentos jurídicos de Portugal e Espanha, de modo que as discussões travadas entre os estudiosos do tema nesses países, incluindo os da América Latina, acabaram evoluindo para propostas de sistematização conjunta e elaboração de anteprojetos de Códigos de Processos Coletivos supranacionais que pudessem servir de parâmetro para o desenvolvimento das legislações nacionais sobre o assunto.

Por esse motivo, justifica-se traçar um breve panorama sobre o tratamento da tutela jurisdicional dos direitos transindividuais em outros ordenamentos de Civil Law e verificar de que forma essa disciplina tem progredido para um tratamento conjunto entre países, buscando maior abrangência e eficiência na proteção de interesses tão importantes e, por vezes, não limitados pelas fronteiras dos Estados nacionais. Analisar-se-ão, ainda, o

Brasileiro de Processos Coletivos redigida pela professora Ada Pellegrini Grinover, disponível em http://www.mpcon.org.br/site/portal/jurisprudencias_detalhe.asp?campo=2897. Acessado em 27jun.2011.

${ }^{74}$ Cf. Capítulo 5, subitem 5.4.

${ }^{75}$ GRINOVER, Ada Pellegrini. Significado social, político e jurídico da tutela...Op. cit., p. 14 
instituto da representatividade adequada em cada um desses ordenamentos e no que eles poderiam dialogar com nosso sistema jurídico, considerando que é esse o ponto central do estudo.

\subsubsection{A evolução da tutela coletiva em outros ordenamentos de Civil Law e o código modelo de processos coletivos para a Ibero-América.}

Buscando uma visão geral sobre o tratamento dos interesses transindividuais e de suas formas de tutela nos ordenamentos de Civil Law, tendo em vista a multiplicidade de países que adotam esse sistema jurídico e que, de alguma forma, positivaram normas sobre o tema, escolheu-se como amostra as legislações de alguns países da Europa continental, que tiveram influência na construção das bases do sistema de proteção aos direitos coletivos. Além disso, a Argentina também foi selecionada para análise, ao lado do Brasil, como representante da América Latina.

A intenção desse breve panorama histórico é verificar como as exigências sociais refletiram na positivação de normas concernentes à tutela dos interesses transindividuais ao longo da história desses países e, assim, apurar qual o atual estágio do tratamento dado ao tema de uma forma global. Não se pretende aqui esgotar todas as especificidades de cada um dos ordenamentos jurídicos no que toca aos direitos transindividuais, tampouco fazer um estudo aprofundado de cada um dos institutos do processo coletivo nesses países. Nessa oportunidade, o foco será a previsão de critérios para a aferição da representatividade adequada, ou a possibilidade de tal aferição, pois consiste no ponto central desta dissertação.

\subsubsection{Itália}

As reflexões dos juristas italianos na década de 1970 foram particularmente relevantes para a internalização, na Itália, dos conceitos referentes à defesa dos direitos transindividuais, uma vez que procuraram conciliar a experiência dos países de Common Law - notadamente a experiência norte-americana - e as necessidades mais prementes do país naquela época, especialmente no que tange à ampliação do acesso à Justiça. Como a tutela dos interesses difusos e coletivos era uma das vias apontadas pelos autores italianos 
para que esse acesso fosse garantido e ampliado $^{76}$ - e essa necessidade de expansão era compartilhada por diversos outros países -, a doutrina difundida por Mauro Cappelletti teve grande penetração nos países de Civil Law.

Muito embora tal país tenha sido o berço das discussões mais modernas sobre o tema, as ideias debatidas pela doutrina não fizeram eco na legislação italiana, ao menos não imediatamente, tendo as ações coletivas se desenvolvido vagarosamente, naquele país, nas últimas três décadas.

Mas, conquanto as discussões acerca do tema tenham se aquecido na Itália a partir da década de 70, pode-se dizer que a existência de direitos coletivos já era -notada bem antes. O sistema de defesa dos direitos transindividuais na Itália, desde suas primeiras manifestações, esteve ligado intimamente com o movimento sindical - haja vista que o surgimento de associações de ordem operária e patronal, ainda no início do século XX, propiciou estudos sobre os interesses coletivos e a sua tutela conjunta ${ }^{77}$. A agregação da chamada classe trabalhadora em torno de interesses comuns tornou-se um símbolo para o despertar de uma nova consciência jurídica que ultrapassasse a esfera meramente individual e protegesse os direitos de um grupo de pessoas - no caso, especificamente, dos trabalhadores $^{78}$.

A evolução legislativa sobre a matéria, no entanto, só veio a ocorrer muito depois, na segunda metade do século XX, durante a efervescência teórica em torno dessas questões. No ano de 1970 entrou em vigor o Statuto dei Lavoratori, em que consta a legitimação dos sindicatos para a tutela dos interesses coletivos, mediante a propositura de ações com o objetivo de fazer cessar a prática de condutas antissindicais e de seus efeitos (artigo 28, Lei 300/1970). As providências permitidas aos sindicatos, em termos de defesa

\footnotetext{
${ }^{76}$ CAPPELLETTI, Mauro; GARTH, Bryant. Acesso à justiça...Op. cit., 49-66.

${ }^{77}$ Descreve Aluísio Gonçalves de Castro Mendes que em 1911 foi publicada obra "La Tutela degli interessi colletivi" do doutrinador Emilio Bonaudi, em que se aborda o desenvolvimento do conceito de interesses coletivos em outros países como a França e Bélgica. No ano seguinte (1912), foi a ver de Ugo Ferrone publicar a obra "Il processo civile moderno: fondamento, progresso e avvenire", em que narra as experiências positivas de outros países na área dos direitos difusos e coletivos, mas assume que tal defesa não é possível pelo ordenamento jurídico italiano da época (MENDES, Aluísio Gonçalves de Castro. Ações coletivas no direito comparado e nacional...Op.cit., p. 96).

${ }^{78}$ Nesse sentido, ainda no ano de 1906, manifesta-se Gioele Solari: “[...] oggo La revisione è invocata in nome di princìpii nuovi, in nome di uma nuova coscienza giuridica inspirata non pur a sentimenti di solidarietà spciale, ma agli interessi specifici del lavoro e delle classi lavoratrici" (tradução livre: atualmente a reforma é invocada em nome de princípios novos, de uma nova consciência jurídica, inspirada não pelo sentimento de solidariedade especial, mas pelos interesses relativos ao trabalho e à classe trabalhadora.). SOLARI, Gioele. Socialismo e diritto privato - Influenza delle odierne dottrine socialiste sul diritto privato. Milano: P. Ungari, 1980, p. 2.
} 
dos direitos dos trabalhadores representados, entretanto, restringiam-se às tutelas inibitórias ${ }^{79}$.

Seguindo essa tendência, ainda no auge das discussões sobre a ampliação do acesso à Justiça pela via dos processos coletivos, a doutrina italiana passou a analisar instrumentos de tutela do Meio Ambiente. O fruto desses debates foi a positivação da Lei no 349/1986, que previa uma série de meios para que legitimados ativos - precipuamente associações ${ }^{80}$ passassem a tutelar os direitos da coletividade relativos à matéria ambiental. As providências que poderiam ser pleiteadas em juízo, mais uma vez, restringiam-se às tutelas inibitórias, visando a paralisação de atitudes que atentavam contra o Meio Ambiente ou representavam ameaça de qualquer natureza a sua integridade.

A mesma orientação se seguiu quando da entrada em vigor da Lei $n^{\circ} 281 / 1998$, que tratava da proteção dos direitos do consumidor - positivada na Itália em virtude de clara influência exercida pelos regulamentos supranacionais da União Europeia, notadamente da diretiva $n^{\circ} .13 / 1993^{81}$. Aponta Andrea Giussani que, em princípio, as associações de defesa do consumidor teriam legitimidade para fazer valer em juízo os interesses da categoria, com a finalidade de conseguir uma tutela inibitória ${ }^{82}$.

\footnotetext{
${ }^{79}$ MENDES, Aluísio Gonçalves de Castro. Ação coletivas no direito comparado e nacional...Op.cit., p. 107-108. Neste sentido, manifestou-se também Andrea Giussani, relator da Itália no XIII Congresso Mundial de Direito Processual, atestando que: "Questa impostazione per un verso há permeso di evitare che gli altri sindicati o addirittura i lavoratori interessati potessero considerarsi litisconsorte necessari nel giudizio rivolto alla repressione della condotta antisindacale (e quindi di evitareche la tutela si rendesse di fato impraticabile), e há consentito al sindacato dia gire senza bisogno di ricevere mandato dai singoli lavoratori (...)" (tradução livre: Essa previsão tem, por um lado, a intenção de evitar que outros sindicatos, uniões e mesmo trabalhadores interessados possam ser considerados litisconsortes necessários em juízo para discutir condutas antissindicais - e de se evitar que a tutela se torne impraticável -, e tem consentido que o sindicato aja sem que cada trabalhador tenha que lhe conferir procuração). GRINOVER, Ada Pellegrini; WATANABE, Kazuo; MULLENIX, Linda. Os processos coletivos nos países de Civil Law e Common Law...Op. cit., p.166.

${ }^{80}$ Assim dispõe o artigo 13 da referida lei, in verbis: Art. 13 - 1. Le associazioni di protezione ambientale a carattere nazionale e quelle presenti in almeno cinque regioni sono individuate con decreto del Ministro dell'ambiente sulla base delle finalità programmatiche e dell'ordinamento interno democratico previsti dallo statuto, nonché della continuità dell'azione e della sua rilevanza esterna, previo parere del Consiglio nazionale per l'ambiente da esprimere entro novanta giorni dalla richiesta. Decorso tale termine senza che il parere sia stato espresso, il Ministro dell'ambiente decide (1).(tradução livre: As associações de proteção ambiental de caráter nacional e que estejam presentes em ao menos cinco regiões são reconhecidas com decreto do Ministro do ambiente com base nas suas finalidades programáticas e de seu ordenamento interno democrático previsto pelo estatuto, e pela continuidade de sua ação e da sua relevância externa, com possibilidade do conselho nacional pelo ambiente manifestar-se sobre o tema. O Ministro do ambiente decide se a associação deve terminar se isso não estiver expresso no estatuto).

${ }^{81}$ Tal diretiva tem como tema principal as cláusulas abusivas em contratos celebrados com o consumidor. Ver http://civil.udg.es/epclp/texts/es/93-13.htm. Acessado em 20dez.2012.

${ }^{82}$ GRINOVER, Ada Pellegrini; WATANABE, Kazuo; MULLENIX, Linda. Os processos coletivos nos países de Civil Law e Common Law...Op. cit., p. 167-168. No mesmo sentido ver HENSLER, Deborah R.; HODGES, Christopher; TULIBACKA, Magdalena (et. alli). The Globalization of Class Action: The
} 
Foi apenas no ano 2000, com a entrada em vigor da Lei ${ }^{\circ}$ 283/2000, que o sistema italiano passou a prever a possibilidade de ressarcimento de danos por meio de ações coletivas. Em um primeiro momento, entretanto, tal ressarcimento limitava-se aos danos coletivos, sendo ainda impossível que a decisão prolatada em uma ação coletiva se prestasse a fundamentar o pedido de ressarcimento dos danos individualmente sofridos até porque nenhuma dessas leis regulava com precisão os limites subjetivos da coisa julgada nas ações coletivas ${ }^{83}$.

A nota marcante da tutela dos direitos transindividuais até o ano de 2008, na Itália, foi a priorização das providências inibitórias - no lugar daquelas voltadas ao ressarcimento dos danos sofridos pelos indivíduos. A legislação, nesse contexto, fazia menção apenas à defesa dos interesses difusos e coletivos, não havendo previsão com relação à possibilidade da tutela por via coletiva dos interesses individuais. Nessa esteira importa assinalar que a doutrina italiana, durante muito tempo, não se preocupou em diferenciar os interesses difusos dos interesses coletivos, sendo os termos usados como sinônimos até a primeira metade da década de $70^{84}$, quando tais conceitos passaram a ser estudados de forma mais aprofundada, resultando em sua diferenciação e maior detalhamento ${ }^{85}$.

Cumpre observar que, salvo raras exceções, predominou até o ano de 2008 a aplicação das regras do processo civil comum aos processos coletivos, o que permitia à doutrina afirmar que, em termos procedimentais, estes em nada se diferenciavam dos processos individuais - o que consistia em um grave problema para a própria utilização dos

annals of the american academy of political and social science. Sage Publications, Vol. 622, March 2009, p. 141 .

83 GRINOVER, Ada Pellegrini; WATANABE, Kazuo; MULLENIX, Linda. Os processos coletivos nos países de Civil Law e Common Law...Op. cit., p. 164.

${ }^{84}$ FERRARA, R. Commentario breve alle leggi sulla giustizia amministrativa. Padova: A. Romano, 2001, p. 367.

85 Durante o Congresso de Pavia, Andrea Proto Pisani destacou que o termo "interesses coletivos" era excessivamente amplo e impreciso, sendo lido de formas diversas nos âmbitos do direito administrativo, do direito civil, do direito constitucional e do direito do trabalho. Posteriormente, vieram a ser caracterizados os direitos difusos como aqueles concernentes a uma categoria indeterminada de pessoas e relativos a um objeto que não fosse passível de apropriação exclusiva e individual, e os direitos coletivos aqueles que pertencessem a um grupo de pessoas ligadas entre si por substrato corporativo. Ver, nesse sentido: CARRATTA, A. Profili processuali della tutela deglio interessi collettivi e diffusi. Torino: Lanfranchi, 2003, p. 94; TROCKER, Nicolo. Interessi collettivi e diffusi. Roma: Giur Treccani, XVII, 1989, p. 2; DENTI, V. Profili civilistici della tutela degli interessi diffusi in Strumenti per La tutela degli interessi difussi della collettivitá. Atti del Convegno Nazionale Bologna - 5 dicembre, 1981, Rimini, 1982, p. 43. 
instrumentos voltados à tutela coletiva e à consolidação dos institutos próprios desse tipo de processo $^{86}$.

Apenas com a entrada em vigor da Lei $\mathrm{n}^{\circ} 99$ de 23.07.2009, responsável por modificar o artigo 140 do Codice del Consumo (Código de Defesa do Consumidor Italiano), foi possível a tutela dos direitos individuais homogêneos - especificamente no que diz respeito aos consumidores - e, também, a tutela ressarcitória dos danos individualmente sofridos, com base na sentença da ação coletiva ${ }^{87}$. A inspiração para tais mudanças pode ser creditada ao intercâmbio de experiências entre os países de ordenamento do Civil Law - o Brasil, por exemplo, já previa a defesa dos direitos individuais homogêneos desde o início da década de 90 - e, também, à influência do sistema norte-americano das Class Actions for Dammages. Confirmando essa última influência, a lei supracitada cria uma espécie de fase de certificação para as ações de classe em defesa dos direitos individuais homogêneos na Itália (Artigo 104.6. do Codice del Consumo $^{88}$ ), passando a prever, inclusive, a necessidade de aferição da representatividade adequada $^{89}$.

\footnotetext{
86 "In Italy, collective actions are provided for by individual statutes or statutory instruments: occasionally, they lay down special rules of procedures, but if this is not the case, the general, ordinary rules governing civil procedure apply. In other words, unless otherwise stated by the law collective actions are no different from any other civil action, at least from a strictly procedural point of view. The system treats association or the public body granted the right of action as an individual plaintiff: there is no need for opt-in or opting-out mechanisms, since in the eyes of the law individual consumers, workers, and so on have no business taking part in the lawsuit". (tradução livre: Na Itália, as ações coletivas estão previstas pelos estatutos individuais ou instrumentos legais: ocasionalmente, eles estabelecem regras específicas de procedimentos, mas se isso não for o caso, aplicam-se as regras do processo civil geral. Em outras palavras, a menos que indicado de outra forma, as ações coletivas não são diferentes de qualquer outra ação civil, pelo menos, de um ponto de vista estritamente processual. O sistema legitima associação ou organismo público, garantindo o direito de ação como a um autor individual: não há mecanismos de opt-in ou opt-out, já que, aos olhos dos consumidores, trabalhadores, e assim por diante, não tem interesse em tomar parte na ação). Trecho reportado por Elisabetta Silvestri. HENSLER, Deborah R.; HODGES, Christopher; TULIBACKA, Magdalena (et. alli). The Globalization of Class Action...Op. cit., p. 144-145.

${ }^{87}$ Art.140-bis. - "(Azione di classe). - O diritti individual omogenei dei consumatori e degli utendi di cui al comma 2 sono tutelabili anche attraverso l'azione di classe, secondo Le previsioni del presente articolo. A tal fineciascun componente della classe, anche mediante associazioni cui dà mandato o comitati cui partecipa, può agire per l'accertamente della reponsabilitá e per la condanna al risarcimento del danno e alle restituzioni". (tradução livre: Os direitos individuais homogêneos dos consumidores e outros referidos no $\mathrm{n}^{\circ} 2$ devem ser protegidos através da ação de classe, de acordo com as disposições do presente artigo. Esse membro da classe pode agir, inclusive por meio de associações ou comissões de que participa, pleiteando a responsabilização e condenação por danos e reembolsos).

${ }_{88}$ Art.104.6. "All'esito della prima udienza Il tribunale decide com ordinanza sull'ammissibilitá della domanda, ma può sospendere Il giudizio quando sui fatti rilevanti ai fini del decidere è in corso um 'istruttoria davanti a um'autorità indiperdente ovvero um giudizio davanti al giudice amministrativo. La domanda $\grave{E}$ dichiarata inammissibile quando è manifestametne infondata, quando sussite um conflitto di interesse ovvero quando Il giudice non ravvisa l'identitá dei diritti individualo tutelabilisi sensi del comma 2 , nonchè quando Il proponente non appare in grado di curar adeguatamente l'interesse della classe". (tradução livre: Na primeira audiência o tribunal deve decidir sobre a admissibilidade do pedido com a ordem, mas pode suspender o julgamento, quando os fatos relevantes para a decisão dependerem de fase
} 
Observa-se, assim, que a Itália ainda está entre os países que, atualmente, não contam com um sistema organizado de tutela dos direitos transindividuais, contando apenas, com leis setoriais em matéria de processo coletivo (e.g. regulamentação sindical, direito ambiental, direito dos consumidores). É inegável, entretanto, o desenvolvimento no tratamento da matéria no decorrer da última década - seja por conta da influência dos regulamentos supranacionais da União Europeia, seja em razão do aumento do intercâmbio de experiências no campo da tutela de tais interesses com outros países. Tal evolução merece destaque por ter passado a a regular expressamente e exigir o controle de institutos ainda ausentes em outros ordenamentos, como é o caso da representatividade adequada, o que ainda não ocorre em outros países, como o Brasil.

\subsubsection{Alemanha}

Fenômeno análogo observou-se no ordenamento jurídico alemão que, em alguma medida, serviu de inspiração para as discussões dos juristas italianos sobre os direitos transindividuais, assim como para a positivação de leis sobre o tema em diversos países europeus e, por fim, para as diretivas da União Europeia.

Diz-se isso porque o ordenamento jurídico alemão já contava com normas que previam a tutela inibitória coletiva para barrar condutas consideradas como concorrência desleal (Gesetz gegen den unlauteren Wettbewerb - UWG) desde 1909. É certo que essa legislação não permaneceu inalterada ao longo de todo o século, tendo contado com algumas modificações em $1965^{90}$. Outra lei prevendo tutelas inibitórias coletivas versava sobre as condições gerais do comércio (Gesetz zur Regelung des Rechts der Allgemeinen Geschäftsbedingungen - AGBG) de 1976.

\footnotetext{
instrutória ou do resultado de outro processo em curso na jurisdição administrativa. A demanda será indeferida quando manifestamente infundadas, ou quando houver conflito de interesse ou, ainda, se o juiz considera o direito tutelável nos termos do $\mathrm{n}^{\circ} 2$, ou se o requerente não é capaz de tratar adequadamente os interesses da classe .)

${ }^{89}$ GRINOVER, Ada Pellegrini; WATANABE, Kazuo; MULLENIX, Linda. Os processos coletivos nos países de Civil Law e Common Law...Op. cit., p. 169-172.

${ }_{90}$ A alteração inserida no ano de 1965 se prestou a incluir a legitimidade das associações de defesa do consumidor para a propositura de ações inibitórias contra atos ilícitos que afetassem, significativamente, os consumidores. Ver, nesse sentido MENDES, Aluísio Gonçalves de Castro. Ação coletivas no direito comparado e nacional...Op. cit., p. 124.
} 
Essas duas leis despertam especial interesse, uma vez que positivaram a legitimidade ativa de associações para a propositura de ações inibitórias visando à proteção da concorrência e do comércio, dando origem às chamadas Verbandsklagen (ações associativas). Em princípio, tais ações se restringiam à tutela dos direitos descritos nas leis já referidas, mas, com o tempo, passaram a ser utilizadas para a defesa de outros interesses transindividuais.

Sempre houve nos tribunais alemães, entretanto, uma firme relutância à implementação de um modelo análogo aos das Class Actions norte-americanas, notadamente aquelas voltadas ao ressarcimento de um grande número de pessoas (mass tort litigation) veiculadas através da Class Action for damages. Por isso todas as ações coletivas previstas em lei, até muito recentemente, limitavam-se às tutelas inibitórias e eram de todo imprestáveis para a persecução de pleitos indenizatórios. Apesar de serem instrumentos muito eficazes para impugnar cláusulas gerais de contratos de adesão e, com isso, sendo também valiosos para a prevenção de condutas potencialmente danosas aos consumidores e ao mercado de uma forma geral - especialmente no contexto da sociedade de massa -, a ausência de vias aptas a pleitear indenizações coletivas se fazia sentir pelos clamores da doutrina alemã ${ }^{91}$.

As exigências sociais no sentido da positivação de uma lei que possibilitasse a veiculação de pleitos ressarcitórios pela via coletiva se tornaram presentes no dia a dia dos tribunais germânicos. Cita-se o caso das duas mil e duzentas ações ajuizadas contra a Deutsche Telekon AG perante a Corte Distrital de Frankfurt, em que um estudo realizado pelo próprio tribunal chegou à conclusão de que seriam necessários quinze anos para decidir todos os casos em primeira instância. Esse problema prático era só um dos que poderiam ser resolvidos por uma postura legislativa que contemplasse novas regras para processos coletivos. Atendendo a essas necessidades, foram positivadas regras para os

91 A previsão que veda o caráter indenizatório das Verbandsklagen está no $\S 2^{\circ},(3)$ da Gesetz über Unterlassungsklagen bei Verbraucherrechts- und anderen Verstößen (UklaG), a lei relativa às ações inibitórias em direitos do consumidor e outras violações: "Der Anspruch auf Unterlassung kann nicht geltend gemacht werden, wenn die Geltendmachung unter Berücksichtigung der gesamten Umstände missbräuchlich ist, insbesondere wenn sie vorwiegend dazu dient, gegen den Zuwierhandelnden einen Anspruch auf Ersatz von Aufwendungen oder Kosten der Rechtsverfolgung entstehen zu lassen “. (tradução livre: Não pode ser feito pedido de medida cautelar quando considerado injusto, diante das circunstâncias globais, principalmente no que se referir a direito a compensação por gastos ou custos de acusação).

Relata Burkhard Hess, relator alemão no XIII Congresso Mundial de Direito Processual Civil ocorrido em 2007, que havia um temor generalizado nas cortes alemãs, do ajuizamento de ações ressarcitórias de grupos de vítimas ou descendentes de vítimas do holocausto. Ver, sobre o assunto, GRINOVER, Ada Pellegrini; WATANABE, Kazuo; MULlENIX, Linda. Os processos coletivos nos países de Civil Law e Common Law...Op. cit., p. 141. 
chamados Musterprocezeß, em 2005. Esse mecanismo pode ser resumido como um sistema de seleção de um caso paradigma para julgamento, cuja solução se aplicará a todos os casos idênticos - servindo para evitar a proliferação de processos individuais sobre um mesmo tema ${ }^{92}$. Uma vez requerida e aceita pelo tribunal a instauração desse procedimento, mediante a descrição das questões de fato e de direito envolvendo a controvérsia de massa, todos os processos individuais sobre o tema serão suspensos, até a decisão final do caso paradigma.

Essa forma adotada pela Alemanha para equacionar o problema da proliferação de processos individuais sobre um mesmo tema - em princípio, sobre danos relacionados a atividades no âmbito do mercado de capitais (securities litigations) - é menos uma ação coletiva e mais um mecanismo para solução conjunta de demandas individuais. A experiência na solução desse tipo de litígio, por essa via específica, mostrou-se muito positiva nos primeiros cinco anos de experiência, de modo que o legislador alemão vem considerando a possibilidade de ampliar o campo de aplicabilidade desse procedimento para outras matérias que requeiram soluções análogas ${ }^{93}$.

\subsubsection{Portugal}

Observa-se, pois, que a maioria dos ordenamentos jurídicos dos países da Europa continental - a exemplo da Itália e da Alemanha - deu à tutela dos interesses transindividuais, em princípio, uma abordagem inibitória, visando cessar ou coibir a prática de atos danosos ou potencialmente danosos aos direitos da coletividade - orientação que foi mantida pelas primeiras diretrizes da União Europeia sobre o tema. Apenas em um segundo momento é que esses países passaram a contemplar ações ou mecanismos capazes de veicular, pela via coletiva, pleitos de ressarcimento tanto dos danos coletivos, quanto dos danos individualmente sofridos.

Tal como ocorreu na maioria dos ordenamentos jurídicos - tanto de Common Law quanto de Civil Law -, foi positivada em primeiro plano a tutela dos interesses difusos e

92 EICHHOLTZ, Stephanie. Die US- amerikanische Class Action und ihre detschen Funktionsäquivalente. Tübingen: Mohr Siebeck, 2002, p. 233-234. Ver também, GRINOVER, Ada Pellegrini; WATANABE, Kazuo; MULLENIX, Linda. Os processos coletivos nos países de Civil Law e Common Law...Op. cit., p. 142-143.

93 GRINOVER, Ada Pellegrini; WATANABE, Kazuo; MULLENIX, Linda. Os processos coletivos nos países de Civil Law e Common Law...Op. cit., p. 144 
coletivos para apenas recentemente - no decorrer das últimas duas décadas - ser incluída a tutela dos interesses individuais homogêneos.

Ademais, também sob influência das citadas diretrizes supranacionais, o tema mais recorrente nas legislações nacionais europeias, no tocante à direitos coletivos ou passíveis de defesa conjunta, são os direitos dos consumidores ${ }^{94}$. Bom exemplo disso são as leis espanholas sobre o assunto, que se limitam a tratar dos direitos dos consumidores, não mencionando quaisquer ações que possam ser exercitadas para proteger os interesses comuns a outros grupos ou setores da sociedade ${ }^{95}$.

Essa perspectiva geral, no entanto, é quebrada pelo ordenamento jurídico português, que desde a década de 70 introduziu a defesa dos interesses coletivos no âmbito constitucional, tendo, a partir de então, desenvolvido um verdadeiro sistema de proteção a tais interesses, que em muito se aproxima do modelo brasileiro.

A ação popular portuguesa - que se presta à defesa dos direitos transindividuais foi inicialmente positivada no artigo 52 da Constituição da República Portuguesa de 1976, prevendo o direito de se ajuizar ação popular, nos casos e nos termos previstos na lei. A redação do artigo constitucional tinha contornos predominantemente inibitórios - tal como ocorrera com os demais ordenamentos jurídicos da Europa -, falando em direito de ação para "promover a prevenção, a cessação ou a perseguição judicial das infracções contra a saúde pública, os direitos dos consumidores, a qualidade de vida, a preservação do ambiente e do património cultural" ${ }^{96}$. A principal diferença do ordenamento jurídico português, com relação aos demais da Europa continental, é que ele previa, desde logo, no mesmo artigo constitucional, a possibilidade dos lesados pleitearem indenização por meio

\footnotetext{
${ }^{94}$ Como aponta o relator Sergio Chiarloni, que abordou a legislação supranacional da União Européia sobre o tema da tutela dos interesses difusos no XIII Congresso Mundial de Direito Processual realizado em Salvador (Brasil), no ano de 2007, "L'Unione europea si ocupa di interessi collettivi da um punto di vista particolare, anche se molto importante. Il punto di vista dela tutela dei consumatori. Non si ocupa né di interessi diffusi (volendosi intendere questi ultimi como interessi ce appartengono ala generalitá dei cittadini, ad esempio l'interesse ala salubrità dell'aria) né di altre categorie di interessi collettivi appartendi a piú ristrette categoria di soggetti (ad esempio gli interessi dei lavoratori)" (tradução livre: A União Europeia se ocupa dos interesses coletivos de um ponto de vista particular, mas muito importante. O ponto de vista da tutela dos consumidores. Não se ocupa dos interesse difusos (entendidos como os interesses de todos os cidadãos, como o interesse na limpeza do ar) ou de outras categorias de interesses coletivos de determinados grupos de pessoas (como os interesses dos trabalhadores). GRINOVER, Ada Pellegrini; WATANABE, Kazuo; MULLENIX, Linda. Os processos coletivos nos países de Civil Law e Common Law...Op. cit., p.21-23.

${ }^{95}$ Neste sentido, manifesta-se o relator espanhol José Luiz Vázques Sotelo no XIII Congresso Mundial de Direito Processual realizado em Salvador (Brasil), no ano de 2007. GRINOVER, Ada Pellegrini; WATANABE, Kazuo; MULLENIX, Linda. Os processos coletivos nos países de Civil Law e Common Law...Op. cit., p. 158-165.

${ }^{96}$ Artigo 52 da Constituição da República Portuguesa de 1976.
} 
da Ação Popular ${ }^{97}$. Assim, desde a década de 1970, Portugal estava munido, ao menos em tese, de meios para a prevenção, bem como para pedido de cessação e reparação de danos decorrentes de infrações contra os direitos transindividuais. Em outras palavras, havia a previsão constitucional, mas a falta da legislação infraconstitucional dificultava sua aplicação.

A lei que efetivamente regulamentou a Ação Popular portuguesa, permitindo sua integral aplicação e sanando a inconstitucionalidade por omissão apontada pela doutrina portuguesa, só veio a ser editada no ano de 1995 (Lei 83/1995) ${ }^{98}$. A entrada em vigor, logo em seguida, do Código de Defesa do Consumidor (Lei 27/1996) e a reforma ocorrida no Código de Processo Civil - que passou a prever a legitimidade ativa de qualquer cidadão no gozo de seus direitos políticos, associações e fundações defensoras dos direito em causa, autarquias locais e do Ministério Público à propositura de "acções para a tutela de direitos difusos" (art. 26º -A do Código de Processo Civil português) - consolidaram o arcabouço legislativo de tutela dos interesses transindividuais em Portugal.

Com isso, observa-se que, conquanto a iniciativa de incluir na Constituição portuguesa a possibilidade de tutela dos interesses transindividuais tenha sido vanguardista, a efetiva aplicação da Ação Popular para a defesa desses direitos só começou a se desenvolver quase vinte anos depois, com a regulamentação da referida ação no âmbito infraconstitucional ${ }^{99}$.

Todos os diplomas legais portugueses falam na tutela dos direitos difusos, de forma genérica, sem definir ou especificar que interesses estariam inclusos nesse conceito. Não

\footnotetext{
${ }^{97}$ Com a lei de 1989, o artigo 52 da Constituição passa a conferir "a todos, pessoalmente ou através de associações de defesa dos interesses em causa, o direito de acção popular nos casos e termos previstos na lei, incluindo o direito de requerer para o lesado ou lesados a correspondente indemnização".

${ }^{98}$ Esclarece Aluísio de Castro Mendes, citando o doutrinador português Carlos Adérito Teixeira, que "Com a entrada em vigor desta lei superou-se uma inconstitucionalidade por omissão decorrente da falta de regulamentação do art. 52, n.3 da CRP, norma por muitos considerada inexequível por si mesma para que pudesse ser invocada a sua aplicabilidade directa, não obstante o carácter perceptivo das normas constitucionais sobre direitos, liberdades e garantias" (Art. 18, n.1, da CRP). Ver: MENDES, Aluísio de Castro. Ação coletivas no direito comparado e nacional...Op. cit., p. 133-134.

${ }^{99}$ Grande parte da doutrina e da jurisprudência portuguesa considerava que as normas constitucionais relativas à ação popular, conquanto fossem bastante específicas, não eram autoaplicáveis. Cite-se o processo n.554/1993, julgado pelo Tribunal Constitucional Português, pelo qual "o Provedor de Justiça veio requerer, em 8 de outubro de 1993, nos termos e para os efeitos do disposto no artigo $283^{\circ}$, ns. 1 e 2 da Constituição, que o Tribunal Constitucional aprecie e verifique o não cumprimento da Constituição por omissão das medidas legislativas previstas no artigo $52^{\circ}, \mathrm{n} .3$, necessárias para tornar exequível o direito de acção popular ali consagrado". Ao final, com a entrada em vigor da lei 83/1995, a ação supra acabou por não ser provida, vez que sanada a inconstitucionalidade por omissão reclamada. Sobre o tema, ver MAZZEI, Rodrigo Reis. Tutela Colectiva em Portugal: uma breve resenha. Verbo Jurídico, 2005. Disponível em http://www.verbojuridico.com/doutrina/brasil/br_tutelacolectivaemportugal.pdf. Acessado em 15jul.2011.
} 
há, pois, uma diferenciação entre os direitos supraindividuais ${ }^{100}$. Por esse motivo, tanto a doutrina quanto a jurisprudência portuguesas têm entendido que a Ação Popular pode ser utilizada indistintamente para a tutela dos interesses difusos, coletivos ou individuais homogêneos - estes últimos definidos como os direitos cujos titulares são numerosos mas identificáveis $^{101}$. Assim, com um único instrumento - a Ação Popular -, o ordenamento jurídico português possibilitou a tutela dos interesses transindividuais de uma forma global, tanto em sua dimensão inibitória quanto indenizatória.

Marcante, nesse sentido, foi o julgamento do Supremo Tribunal de Justiça de Portugal, realizado em 1997 - dois anos após a entrada em vigor da lei 83/1995 -, asseverando que:

I - o artigo $1^{\circ}$ da Lei n. 83/95, de 31 de agosto, abrange não só os “interesses difusos" (interesses de toda a comunidade) como ainda os "interesses individuais homogêneos" (os que se polarizam em aglomerados identificados de titulares paralelamente justapostos).

II - o direito de reparação de danos dos assinantes do serviço telefónico por incumprimento do contrato inclui-se na categoria dos "interesses homogéneos individuais" $^{102}[\ldots]$.

No que toca à positivação da possibilidade ou necessidade de aferição da representatividade adequada, vários autores apontam que o ordenamento jurídico português se aproximou do modelo brasileiro, nada falando sobre a aferição da representatividade dos autores coletivos e sobre a possibilidade do controle jurisdicional desse requisito, mas estabelecendo critérios legais para a verificação da legitimidade - especialmente das pessoas jurídicas legitimadas. Para estas, o artigo $3^{\circ}$ da Lei $n^{\circ}$. 83/95 prescreve que a instituição deve incluir em seus objetivos estatutários a defesa dos interesses tutelados e não pode exercer nenhum tipo de atividade profissional concorrente com empresas ou profissões liberais ${ }^{103}$.

\footnotetext{
${ }^{100}$ SILVA, F. Nicolau dos Santos. Os interesses supraindividuais e a legitimidade processual civil activa. Coimbra: Quid Juris, 2002, p. 15-70.

${ }^{101}$ GRINOVER, Ada Pellegrini; WATANABE, Kazuo; MULLENIX, Linda. Os processos coletivos nos países de Civil Law e Common Law...Op. cit., p. 41.

${ }_{102}$ Acórdão do Supremo Tribunal de Justiça de Portugal - Relator Miranda de Gusmão, 23.09.1997.

${ }^{103}$ Entre os doutrinadores que acreditam que o sistema português esteja muito próximo do brasileiro no que tange à aferição da representatividade adequada encontram-se Humberto Teodoro Junior e Ada Pellegrini Grinover. Esta última autora, em artigo analisando a ação popular portuguesa sob perspectiva comparística, asseverou: "E certamente a lei portuguesa distanciou-se - como a brasileira - do critério de representatividade adequada das class actions, o qual permite ao juiz aferir caso a caso, em face das suas circunstâncias, a seriedade, a credibilidade, a 'representatividade', enfim, das pessoas físicas e jurídicas amplamente legitimadas pelo sistema, que se façam portadoras, em juízo, dos interesses metaindividuais. [...] o juiz pode indeferir a inicial, mas não pode negar a legitimação - que é exclusivamente determinada por lei
} 
Quer nos parece, entretanto, que o ordenamento jurídico português seguiu a mesma linha adotada pela Alemanha nesse tocante. Ou seja, ainda que não traga uma norma expressa atestando que o representante deverá ser adequado - ou que o juiz está autorizado aferir a representatividade adequada do autor coletivo -, conta com diversos dispositivos legais que, analisados em conjunto, denotam essa necessidade.

Analisem-se conjuntamente, por exemplo, os artigos 16 e 19 da Lei $n^{\circ} .83 / 95$. Eles propõem uma espécie de controle subjetivo da atuação do autor coletivo, prescrevendo que caso ele não se comporte corretamente - ou mesmo haja em conflito de interesses -, estará sujeito à remoção do polo ativo, sendo a condução da ação assumida pelo Ministério Público $^{104}$. O controle desse comportamento do legitimado ativo poderá ser feito pelo juiz - a quem também é conferido o poder de restringir os efeitos da coisa julgada com base em "motivações de cada caso concreto"105 - e pelo Ministério Público enquanto fiscal da lei.

Assim, permitir ao juiz que restrinja os efeitos da coisa julgada de acordo com as circunstâncias do caso equivale dizer que o autor não representou adequadamente todos os integrantes da classe - o mesmo acontecendo acaso se determine a substituição do polo ativo em virtude da apuração de comportamentos lesivos para o interesse da causa ${ }^{106}$. Por esse motivo, entende-se que Portugal contempla a possibilidade de aferir - ainda que indiretamente - a representatividade adequada dos autores coletivos ou, ao menos, deixou em sua legislação uma margem maior para essa aferição se comparado com o ordenamento jurídico brasileiro.

De forma geral, vale dizer que Portugal não é o único país europeu com um sistema organizado de tutela dos interesses difusos, coletivos e individuais homogêneos, cabendo ressaltar a recente experiência dos países nórdicos - Suécia, Noruega e Dinamarca - que

- e sim quando entenda ser manifestamente improvável a procedência do pedido, ouvido o Ministério Público e feitas, preliminarmente, as averiguações que o julgador tenha por justificadas ou que o autor ou Ministério Público requeiram (art.13). Trata-se aqui do indeferimento da inicial por ausência do fumus boni iuris, e não da aferição de representatividade como elemento essencial da legitimação para agir". Ver: "A ação popular portuguesa: uma análise comparativa" (GRINOVER, Ada Pelegrini. In: GRINOVER, Ada Pellegrini (org). A marcha do processo. Rio de Janeiro: Forense Universitária, 2000, p. 52).

104 Artigo 16, nº 3 da Lei 83/95. "No âmbito da fiscalização da legalidade, o Ministério Público poderá, querendo, substituir-se ao autor em caso de desistência da lide, bem como de transação ou de comportamentos lesivos ao interesse da causa."

105 Artigo 19, nº.1 da Lei 83/95. “As sentenças transitadas em julgado proferidas em acções ou recursos administrativos ou em acções cíveis, salvo quando julgadas improcedentes por insuficiência de provas, ou quando o julgador deva decidir por forma diversa fundado em motivações próprias do caso concreto, têm eficácia geral, não abrangendo, contudo, os titulares dos direitos ou interesses que tiverem exercido o direito de se auto-excluírem da representação." ]

${ }^{106}$ PASCHOAL, Maximilian Fierro. A representatividade adequada na ação coletiva brasileira...Op. cit., p. 220. 
durante a última década positivaram regras completas acerca do tema, abordando até mesmo a tutela dos interesses individuais homogêneos, regulando os pleitos indenizatórios coletivos e positivando o requisito da representatividade adequada ${ }^{107}$.

No entanto, Portugal foi o primeiro país europeu a dialogar com os ordenamentos jurídicos sul-americanos no que toca à tutela dos interesses transindividuais, especialmente o brasileiro que, à época da entrada em vigor da Lei 83/95, já contava com uma experiência de mais de dez anos de vigência da lei da Ação Civil Pública e quatro anos de vigência do Código de Defesa do Consumidor. As identidades normativa, linguística e cultural, somadas ao desejo de criar um modelo que pudesse inspirar reformas legais tendentes a consolidar o reconhecimento dos direitos difusos, coletivos e individuais homogêneos - bem como suas formas de defesa em juízo - desencadearam as discussões acerca de um Código Modelo de Processos Coletivos para a Ibero-América.

\subsubsection{Argentina}

A legislação sobre a tutela dos interesses transindividuais na Argentina é, em sua maior parte, anterior à elaboração do projeto que veio a dar origem ao Código Modelo de Processos Coletivos para a Ibero-América. Tais normas se desenvolveram sobremaneira no decorrer das últimas duas décadas, o que torna o ordenamento jurídico desse país especialmente interessante para a análise da evolução do processo coletivo na América Latina - em comparação com o Brasil, que já foi analisado.

A reforma constitucional argentina, levada a cabo no ano de 1994, reconheceu expressamente a existência e a possibilidade de tutela dos direitos difusos ou de incidência coletiva. O artigo 43 da Constituição Argentina passou a prever o que se chamou de "amparo coletivo" - um tipo de ação contra qualquer forma de discriminação, ou então ações tendentes à tutela dos direitos ao meio ambiente, do consumidor e todos os demais de incidência coletiva em geral, fazendo constar em seu texto, ainda, os legitimados para a propositura desse tipo de ação, no caso, o próprio prejudicado, o defensor do povo e as associações que se propusessem a esse fins ${ }^{108}$.

\footnotetext{
107 GRINOVER, Ada Pellegrini; WATANABE, Kazuo; MULLENIX, Linda. Os processos coletivos nos países de Civil Law e Common Law...Op. cit.,58-84

${ }^{108}$ Artículo 43- "Toda persona puede interponer acción expedita y rápida de amparo, siempre que no exista otro medio judicial más idóneo, contra todo acto u omisión de autoridades públicas o de particulares, que en forma actual o inminente lesione, restrinja, altere o amenace, con arbitrariedad o ilegalidad manifiesta,
} 
Conquanto a jurisprudência, o Código Civil e o Código Comercial da Nação de 1993 já contemplassem a possibilidade da defesa dos direitos difusos ${ }^{109}$, a inclusão deles na Constituição foi um marco para o efetivo desenvolvimento da disciplina no direito argentino. $\mathrm{O}$ detalhado dispositivo constitucional passou a figurar como um guia para a positivação e efetivação da tutela dos interesses difusos e coletivos nos ordenamentos jurídicos de cada uma das vinte e três províncias da Argentina ${ }^{110}$, cada uma delas com grande autonomia administrativa e legislativa.

Por um lado, essa autonomia entre as províncias possibilitou o atendimento das necessidades regionais, a partir da positivação de regras específicas. Entretanto, por outro lado, gerou uma grande disparidade de tratamento a diversas matérias legais - entre elas os direitos coletivos - tendo como resultado o fato que algumas províncias têm regramentos extremamente detalhados sobre o tema e outras sequer mencionam a possibilidade de sua tutela. Em algumas delas estão positivadas a tutela inibitória e a tutela ressarcitória por meio das ações coletivas. Outras contam com normas viabilizando a tutela dos direitos individuais homogêneos, enquanto algumas não fazem menção sobre o tema.

$\mathrm{O}$ arcabouço legislativo da tutela dos interesses transindividuais na Argentina está positivado, além da Constituição, na Lei de Defesa do Consumidor (Ley Nacional 24.240 de 1994) e na Lei de Política Nacional Ambiental (Ley Nacional 25.675 de 2002) - ambas aplicáveis a todas as províncias, indistintamente. Ainda que não fale expressamente da possibilidade de tutela dos interesses individuais homogêneos, o artigo 52 da Lei de Defesa

derechos y garantías reconocidos por esta Constitución, un tratado o una ley. En el caso, el juez podrá declarar la inconstitucionalidad de la norma en que se funde el acto u omisión lesiva.

Podrán interponer esta acción contra cualquier forma de discriminación y en lo relativo a los derechos que protegen al ambiente, a la competencia, al usuario y al consumidor, así como a los derechos de incidencia colectiva en general, el afectado, el defensor del pueblo y las asociaciones que propendan a esos fines, registradas conforme a la ley, la que determinará los requisitos y formas de su organización. [...]". (tradução livre: Qualquer pessoa pode ingressar com ação de amparo, sempre que não exista outro meio judicial mais idôneo, contra todo ato ou omissão de autoridades públicas ou particulares, que de forma atual ou iminente, restrinja, altere ou ameace com arbitrariedade ou ilegalidade manifesta, direitos e garantias reconhecidos por esta Constituição, um tratado ou uma lei. No caso, o juiz poderá declarar a inconstitucionalidade da norma em que se funde o ato ou omissão lesiva.

Poderão ingressar com essa ação contra qualquer forma de discriminação e no que foi relativo a direitos que protegem o ambiente, a competência, ao usuário e ao consumidor, assim como os direitos de incidência coletiva em geral, o afetado, o defensor do poro e as associações que tenham esses fins, registradas conforme a lei, que determinará os requisitos e formas de sua organização.) .

${ }^{109}$ BERIZONCE, Roberto; GRINOVER, Ada Pellegrini; SOSA, Angel Landoni. Exposição de Motivos do Código Modelo de Processos Coletivos para Ibero-América. PUC SP, Outubro de 2004, disponível em http://www.pucsp.br/tutelacoletiva/download/codigomodelo_exposicaodemotivos_2_28_2_2005.pdf.

Acessado em 23mai.2010.

110 ARGENTINA. Portal Oficial del Gobierno. Disponível em: http://www.argentina.gov.ar/argentina/ portal/paginas.dhtml?pagina=356. Acessado em 12abr.2010. 
do Consumidor dispõe acerca do direito dos consumidores à indenização e, mais do que isso, estabelece punitive damages - que consistem em uma penalidade aplicada aos réus para desencorajar condutas atentatórias ao direito do consumidor ${ }^{111}$. Na Lei de Política Nacional do Meio Ambiente, os artigos 30 e 31 garantem a possibilidade de veicular pleito de ressarcimento de danos coletivos e individuais pela via coletiva, além de assegurarem o direito de qualquer cidadão ingressar com uma ação para fazer cessar os atos danosos ao meio ambiente.

Essas duas leis de incidência nacional, entretanto, limitam-se ao âmbito de seus temas - proteção do consumidor e do meio-ambiente -, de modo que o país, até o presente momento, carece de um sistema próprio para a defesa de todos os direitos transindividuais.

No que diz respeito às diferenças regionais, as províncias de Catamarca e Rio Negro são descritas como as que têm os sistemas mais desenvolvidos de tutela dos interesses transindividuais. Na província da Catamarca, a lei local nº. 5034/2001 prevê uma ação para prevenção dos danos coletivos (inibitória) e ações voltadas à reparação em espécie e reparação pecuniária. Não há, entretanto, previsão da possibilidade de tutela dos direitos individuais homogêneos, limitando-se a lei a falar nos interesses difusos e coletivos. Na província de Rio Negro chama atenção justamente o oposto: o Código Processual Civil e Comercial positivou, desde 2007, a possibilidade da tutela dos direitos individuais homogêneos ${ }^{112}$.

A falta de uniformidade entre as legislações das províncias, a aprovação do Código Modelo de Processos Coletivos para a Ibero-América e o aumento de decisões dos tribunais a respeito dos direitos transindividuais aqueceram, na Argentina, as discussões referentes à positivação de um sistema normativo completo sobre os processos coletivos. Ainda que se tenha por assente na doutrina argentina que o modelo proposto a todos os

\footnotetext{
${ }^{111}$ Artículo 52 bis: Daño Punitivo. Al provedor que no cumpla sus obligaciones legales o contractuales con el consumidor, a instancia del damnificado, el juez podrá aplicar una multa civil a favor del consumidor, la que se graduará en función de la gravedad del hecho y demás circunstancias del caso, independientemente de otras indemnizaciones que correspondan. Cuando más de un proveedor sea responsable del incumplimiento responderán todos solidariamente ante el consumidor, sin perjuicio de las acciones de regreso que les correspondan. La multa civil que se imponga no podrá superar el máximo de la sanción de multa prevista en el artículo 47, inciso b) de esta ley. (tradução livre: Dano punitivo. Ao provedor que não cumprir suas obrigações legais ou contratuais com o consumidor, a pedido do prejudicado, o juiz poderá aplicar uma multa civil a favor do consumidor, que será graduada em função da gravidade do feito e demais circunstâncias do caso, independentemente de outras indenizações que corresponda. Quando mais de um provedor for rresponsável pelo descumprimento, responderão todos solidariamente ante o consumidor, sem prejuído das ações de regresso que couberem. A multa não poderá ultrapassar o quanto fixado no artigo 47, inciso $b$ dessa lei).

112 GRINOVER, Ada Pellegrini; WATANABE, Kazuo; MULLENIX, Linda. Os processos coletivos nos países de Civil Law e Common Law...Op. cit., p. 84-87.
} 
países ibero-americanos não pode ser incorporado sem reservas ao país, a iniciativa foi considerada positiva e os clamores sociais por uma legislação que facilite e universalize a tutela dos direitos coletivos se fizeram sentir na jurisprudência ${ }^{113}$.

\subsubsection{Código Modelo de Processos Coletivos para a Ibero-América}

A ideia da elaboração de um Código Modelo de Processos Coletivos para IberoAmérica surgiu em Roma no ano de 2002, partindo da proposta do jurista brasileiro Antonio Gidi. A partir desse momento formou-se um grupo de juristas ibero-americanos que elaboraria a primeira versão do anteprojeto - ao autor da proposta juntaram-se os professores Ada Pellegrini Grinover e Kazuo Watanabe. Após intensas discussões e aportes de diversos estudiosos ibero-americanos do tema da tutela dos interesses transindividuais, o Código Modelo foi aprovado dois anos depois, em 2004, durante as Jornadas do Instituto Ibero-Americano de Direito Processual realizadas em Caracas ${ }^{114}$.

Seu texto teve como inspiração as legislações já vigentes nos países da comunidade ibero-americana, contudo buscou aperfeiçoar e harmonizar as regras existentes - além de trazer à baila a experiência e alguns institutos das Class Actions norte-americanas - tendo, entretanto, se afastado de todos esses modelos para a consolidação de um sistema original, adequado às diversas realidades dos países ibero-americanos. Dois traços característicos de ordenamentos jurídicos nacionais foram aproveitados e positivados no código modelo: (i) a divisão e a terminologia empregadas no direito brasileiro para identificar cada uma das categorias dos direitos transindividuais e (ii) os requisitos de predominância das questões comuns sobre as individuais e da utilidade da tutela pela via coletiva no caso concreto ${ }^{115}$.

Com isso foi possível criar um repositório normativo que fosse passível de utilização por todos esses países, já que se pautou pela eliminação de caracteres

\footnotetext{
${ }^{113}$ Possível fazer referência a dois casos importantes da jurisprudência Argentina: o Caso Halabi (ação de amparo $\mathrm{n}^{\mathrm{o}}$ 270. XLII), em que a Corte Suprema de Justiça da Nação (CSJN) reconhece a possibilidade da tutela coletiva dos interesses individuais homogêneos; e o Caso Viceconte, em que se discute a implementação de uma política pública de vacinação e expõe o bem sucedido - case menagement - pelo juiz, que ficou responsável por acompanhar a execução do julgado. Ver: CELS. Amparo colectivo por derecho a la salud - Caso Viceconte. Disponível em: http://www.cels.org.ar/documentos/index.php?info=detalleDoc\& ids=3\&lang=es\&ss=\&idc=601. Acessado em 25abr.2010. Fallo H.270.XLII, de 24/09/2009, ver: http://www.csjn.gov.ar/documentos/verdoc.jsp. Acessado em 25 de abril de 2010.

${ }^{114}$ A comissão revisora foi integrada por juristas como Aluísio de Castro Mendes, Aníbal Quiroga León, Enrique M. Falcón, José Luiz Vázquez Sotelo, Ramiro Bejarano Guzmán, Roberto Beizonce e Sérgio Artavia. A versão final do projeto foi revisada pelo professor uruguaio Angel Landoni Sosa. GRINOVER, Ada Pellegrini; WATANABE, Kazuo; MULLENIX, Linda. Os processos coletivos nos países de Civil Law e Common Law...Op. cit., p. 25.

${ }^{115}$ Ibid., p. 26.
} 
eminentemente nacionais ${ }^{116}$. No entanto, esse Código não pretende, de maneira alguma, ser incorporado sem reservas por todos os países, mas poderá e deverá ser adaptado a cada um dos ordenamentos jurídicos nacionais, levando em consideração as peculiaridades locais e buscando maior uniformidade no tratamento da tutela dos direitos difusos, coletivos e individuais homogêneos na Ibero-América.

O novo Código foi essencial ao desenvolvimento dos sistemas de defesa de direitos transindividuais nos países de Civil Law, notadamente nos países latino-americanos, tendo influenciado o aperfeiçoamento dos ordenamentos jurídicos de países como Colômbia, Argentina $^{117}$ e Venezuela. Incentivou a reflexão sobre o sistema espanhol, ainda pouco desenvolvido, e o debate acerca de uma segmentação mais adequada dos tipos de direitos difusos em Portugal - já que, nesse país, os direitos individuais homogêneos não estão bem delimitados. Por fim, e certamente constituindo uma das melhores contribuições do projeto para o tema em comento, o Código Modelo promoveu o contato entre os estudiosos do tema em todos os países, alinhando-os em um esforço conjunto para a democratização da justiça por meio da promoção das ações coletivas ${ }^{118}$.

Dentro desse contexto, da evolução dos meios de tutela dos interesses transindividuais, o Brasil ocupa lugar de destaque por ter desenvolvido um sofisticado microssistema para esse fim. Em nossa legislação foi atribuída legitimidade ativa para propositura de ações voltadas às defesa da coletiva à diversas entidades - algumas delas ligadas ao poder do Estado e outras representantes da sociedade civil. Essas últimas, as associações, serão analisadas de forma pormenorizada no próximo capítulo, desde sua estruturação até os motivos pelos quais foram eleitas como representantes da sociedade junto ao poder judiciário. Isso para que seja possível discutir que características essas entidades devem apresentar para que sejam consideradas efetivas representantes da coletividade - e se é possível em nosso sistema legal exigir tais características para que se atribua legitimidade ativa à associação.

\footnotetext{
${ }^{116}$ GRINOVER, Ada Pellegrini; WATANABE, Kazuo; MULLENIX, Linda. Os processos coletivos nos países de Civil Law e Common Law...Op. cit., p. 26.

${ }_{117}$ Sobre o tema, ver "Algunas reflexiones sobre la aplicación de Anteproyecto de Código Modelo de Procesos Colectivos para Iberoamérica en la República Argentina” (BERMEJO, Patricia. In: GIDI, Antonio; e MAC-GREGOR, Eduardo Ferrer. La tutela de los derechos difusos, colectivos e individuales homogéneos: hácia un codigo modelo para Iberoamérica. México: Porrúa, 2003. A autora tece algumas críticas acerca da compatibilização dos termos do Código Modelo que, à época ainda era um projeto, mas considera que o Código supranacional constituirá uma excelente fonte de princípios para a uniformização da legislação sobre processos coletivos na Ibero-América.

118 GRINOVER, Ada Pellegrini; WATANABE, Kazuo; MULLENIX, Linda. Os processos coletivos nos países de Civil Law e Common Law...Op. cit., p. 28-35 e PASCHOAL, Maximilian Fierro. A representatividade adequada na ação coletiva brasileira...Op. cit., 2006, p. 254.
} 
Sabe-se que em diversos ordenamentos jurídicos a aferição da representatividade adequada e os requisitos a serem verificados estão legalmente previstos, o que não acontece no Brasil. Assim, partindo dos elementos que cercam o conceito de associação e, posteriormente, dos critérios que cercam à atribuição de legitimidade ativa para essas entidades atuarem em defesa dos interesses transindividuais em nosso país, que será analisada a possibilidade de aferição da representatividade adequada pelos juízes brasileiros, bem como a forma como isso tem sido feito por nossos tribunais. 


\section{AS ASSOCIAÇÕES CIVIS}

No capítulo anterior foi realizada uma análise da evolução da tutela dos direitos transindividuais no Brasil, trazida ao ordenamento jurídico pátrio como mecanismo indispensável para assegurar o acesso à justiça e dar vazão à litigiosidade contida. A lei atribuiu legitimidade à diversas entidades, inclusive às associações civis. A este estudo interessa a defesa dos interesses transindividuais pela sociedade civil organizada em associações, bem como a possibilidade da aferição pelos juízes da representatividade adequada dessas entidades. Em vista disso, este capítulo se ocupará de uma análise mais aprofundada das associações civis, buscando entender um pouco sua história, a forma como tais agrupamentos surgem no seio da sociedade como veículo de seus anseios e como são regulados pelo ordenamento jurídico brasileiro e no direito comparado.

\subsection{PANORAMA HISTÓRICO - REPRESSÃO, TOLERÂNCIA E FOMENTO DAS ASSOCIAÇÕES NA HISTÓRIA CONSTITUCIONAL BRASILEIRA}

Ao longo da história é possível observar diferentes momentos de interação entre a sociedade, o poder estatal e as associações, que nada mais são que um grupo organizado de pessoas que visa atingir finalidades comuns, sendo possível observar que, tanto no Brasil quanto no resto do mundo, alternaram-se períodos de repressão, reconhecimento e promoção por parte do Estado das atividades associativas. Tais tendências acompanharam as marcantes movimentações sociais da civilização ocidental desde o início do período histórico conhecido como Modernidade - a passagem de uma concepção corporativista ${ }^{119}$ da sociedade, característica da Idade Média, para uma concepção individualista ${ }^{120}$, marca

\footnotetext{
119 A Idade Média, conforme relatos históricos de diversas fontes, foi a época em que floresceram as corporações de ofício, em que se reuniam os praticantes de determinada atividade com o objetivo de desenvolvê-la conjuntamente. Nesse sentido, ver HUBERMAN, Leo. A história da riqueza do homem. 21. ed. Rio de Janeiro: Guanabara, 1986, p. 33-34.

Assevera, ainda, Rodrigo Xavier Leonardo que "a representação da sociedade no pensamento medieval seria dominada pela idéia de 'corpo', de uma organização supra individual dotada de um fim próprio. (...) Pode-se dizer que um dos principais sinais identificadores desse tempo residia, justamente na desigualdade formal entre os indivíduos que se projetava desde a titularidade de direitos até as obrigações tributárias que entre eles pesava desproporcionalmente". (LEONARDO, Rodrigo Xavier. As associações em sentido estrito no direito privado. 2006. 258f. Tese (Doutorado em Direito Civil) sob a orientação do Prof. Alcides Tomasetti Jr. - Faculdade de Direito, Universidade de São Paulo, São Paulo, 2006).

${ }^{120}$ Com a ascensão da filosofia iluminista na Europa - que culminou com a revolução francesa -, observou-se uma valorização do indivíduo em detrimento das associações, que predominava o receio de que a vontade do conjunto se sobrepusesse à vontade individual. Expressa esse receio Jean-Jaques Rousseau, assinalando que "Se, quando o povo suficientemente informado delibera, não tivessem os cidadãos qualquer comunicação
} 
da era moderna. Ainda que não com a mesma intensidade, a concepção social individualista predominou até o final do século XIX, tendo cedido de forma mais clara a partir da segunda metade do século XX, quando surgiu no ocidente do pós-guerra a ideia de solidariedade e colaboração entre os indivíduos ${ }^{121}$.

Logo após o advento da idade moderna, época em que predominava a concepção social individualista, as associações foram, em um primeiro momento, reprimidas, já que a valorização da liberdade individual da pessoa, em sua visão mais extremada, não admitia quaisquer intermediários entre o cidadão e o Estado. Em um segundo momento, marcado pelos ecos da Revolução Industrial, que se estendeu desde a segunda metade do século XIX até a primeira metade do século $\mathrm{XX}^{122}$, o associativismo passou a ser reconhecido em alguns países sob a tutela do Estado e dependente de sua autorização ${ }^{123}$. E, desde meados do século passado, a formação de corpos intermediários, cujo campo de atuação situa-se entre o indivíduo e o Estado, passou a ser promovida e incentivada pelos mais diversos meios.

entre si, do grande número de pequenas diferenças resultaria sempre a vontade geral e a deliberação seria sempre boa. Mas quando se estabelecem facções, associações parciais a expensas da grande, a vontade de cada uma dessas associações torna-se geral em relação a seus membros e particular em relação ao Estado: poder-se-á dizer então não haver mais tantos votantes quanto são homens, mas somente tantas quantas são as associações”. (ROUSSEAU, Jean Jacques. Do contrato social. Traduzido por Lourdes Santos Machado. 5. ed. São Paulo: Nova Cultural, 1991). Tal receio acabou sendo expressado na Declaração de Direitos do Homem e do Cidadão de 1789 que, em seu artigo $3^{\circ}$ dispunha: "o princípio de toda soberania reside essencialmente na Nação. Nenhuma corporação ou estamento, nenhum indivíduo pode exercer autoridade que não emane expressamente dela".

${ }^{121} \mathrm{O}$ ideário dos direitos fundamentais de terceira geração - que preconizam, justamente, a solidariedade e colaboração entre os indivíduos - está ligada ao contexto da sociedade de massa, em que as trocas no mercado e as relações jurídicas se concretizam em grande escala. A organização dos indivíduos em grupos entre eles as associações -, bem como a atribuição de legitimidade a esses grupos para a defesa de seus direitos, prestaria-se a um fortalecimento da sociedade civil que, de outra forma, não agregaria força suficiente para se manter nesse panorama de relações massificadas. Nesse sentido ver CAPELETTI, Mauro. Formações sociais e interesses coletivos...Op. cit., p. 128-132.

${ }^{122}$ A revolução industrial se inicia na Inglaterra ainda no século XVII, mas alcança proporções mundiais, se espalhando pelos países da Europa Continental, América e Ásia entre 1850 e 1900 (ver HOBSBAWM, Eric J. A era das revoluções. 19. ed. São Paulo:Editora Paz e Terra, 2005). Sobre a mudança gradativa dos ordenamentos jurídicos, nesse sentido, assinala Rodrigo Xavier Leonardo (2006) que essa mudança de postura com relação às associações pode ser observada com certa clareza nos ordenamentos jurídicos da época em Portugal, Espanha, Itália e França (LEONARDO, Rodrigo Xavier. As associações em sentido estrito...Op. cit., p. 28).

${ }^{123}$ Essas influências se fizeram sentir até a primeira metade do século XX quando a Europa, sob influência de ditaduras como a fascista e a nazista, controlava o surgimento e o desenvolvimento das atividades das associações, mediante o reconhecimento ou não de personalidade dessas entidades. Essa foi a realidade na Itália fascista, como descreve o doutrinador Massimo Basile: “[...] la strategia politica seguita dal Regime nel confronti dell 'associacionismo era consstita nella promozione e nella tutela degli enti funzionali ai suoi obiettivi, ma al contempo nella loro sottoposizioni al controlo del partito e dello Stato". (tradução livre: a estratégia política seguida pelo Conselho em relação ao associativismo consistiu na promoção e proteção dos corpos funcionais para seus objetivos, mas, ao mesmo tempo, em suas posições no controle do Partido e do Estado.). BASILE, Massimo. Le persone giuridiche. Giuffré: Milano, 2003, p.8. 
Especificamente no que diz respeito ao ordenamento jurídico brasileiro, não se pode dizer que ele tenha acompanhado as tendências mundiais de maneira uniforme, até porque passou por alguns dos períodos históricos supracitados ainda como colônia de Portugal. De todo modo, a liberdade de associação - como base fundamental do reconhecimento das atividades de grupos organizados da sociedade civil - nem sempre esteve expressamente contida na Constituição e nas normas infraconstitucionais, tendo conquistado seu espaço gradativamente, na medida em que as mudanças da sociedade assim determinavam.

Partindo de uma análise do direito positivo nacional, a história do papel das associações civis pode ser estudada pelo prisma constitucional. Na Constituição do Império, outorgada em 1824, não havia menção expressa à liberdade de associação, tampouco dispositivo vedando sua organização - conquanto houvesse previsão à abolição das corporações de ofício (artigo 179, XXV). Diante da omissão, surgiram algumas dúvidas na doutrina quanto à postura do Estado com relação às associações - se tolerante ou repressiva. A partir de uma interpretação conjuntural, o comportamento do governo imperial diante de questões relativas ao associativismo, verifica-se que não há uma garantia implícita ou que, ao menos, ela não era suficiente para assegurar a pacífica constituição e manutenção de uma associação naquela época ${ }^{124}$.

Após a proclamação da República, com o advento da Carta Constitucional de 1891, muniu-se o ordenamento jurídico pátrio de base sólida para o desenvolvimento das entidades associativas. Não apenas a Constituição Federal passou a prever expressamente a liberdade de associação (artigo 72, $\S 8^{\mathbf{o}^{125}}$ ), como a legislação infraconstitucional foi alterada para possibilitar o exercício da garantia recém-reconhecida ${ }^{126}$. Ainda sob a égide

\footnotetext{
${ }^{124}$ O constitucionalista José Antônio Pimenta Bueno, interpretando a Constituição de 1824, considerava que a omissão do texto constitucional especificamente quanto à constituição das associações conjugada com a garantia geral de liberdade (artigo 179 da Constituição de 1824) eram suficientes para garantir a liberdade de associação - mas que tal liberdade era solapada pelas práticas das autoridades na época. (BUENO, José Antonio Pimenta. Direito Público brasileiro e análise da constituição do império Rio De Janeiro: Ministério da Justiça e Negócios Interiores, Serviço de Documentação, 1958, p. 398). Reafirmando essa posição, anota Rodrigo Xavier Leonardo que a proibição das sociedades secretas pela Lei de 20 de outubro de 1823 e, principalmente, a definição demasiadamente ampla do que seria uma sociedade secreta inviabilizavam a criação de associações que não fossem submetidas a um pedido de autorização para o governo (LEONARDO, Rodrigo Xavier. As associações em sentido estrito...Op. cit., p.39-40).

125 Artigo 72, $\S 8^{\circ}$ - A todos é lícito associarem-se e reunirem-se livremente e sem armas; não podendo intervir a polícia senão para manter a ordem pública.

${ }^{126}$ Citem-se, como exemplos, o Decreto $\mathrm{n}^{\circ} 164$ de 17 de janeiro de 1890 em que foi resguardada a liberdade de constituição de sociedades civis ou comerciais; e a Lei 173 de 10 de setembro de 1893 que trata da organização de associações para fins religiosos, morais, científicos, artísticos, políticos ou de simples recreio, estabelecendo a personificação das associações mediante o registro do seu contrato social, mas sem deixar de
} 
da primeira Constituição da República, entrou em vigor o Código Civil de 1916, que continha regras referentes às pessoas jurídicas, entre as quais estavam as associações civis $^{127}$.

A Constituição de 1934 manteve expressa a previsão da liberdade de associação, garantindo que tais entidades não poderiam ser dissolvidas senão por sentença judiciária (artigo 113, XII). Essas garantias permaneceram no texto da Constituição Federal de 1937, apesar do período autoritário que com ela se inaugurou. A liberdade de associação foi tolhida, nessa época, pela legislação infraconstitucional, que conferiu ao Poder Executivo a faculdade de dissolver partidos políticos, assim como quaisquer organizações que os auxiliassem, por meio do Decreto-lei $\mathrm{n}^{\circ} 37$ de 2 de dezembro de 1937. Dada sua generalidade, o Decreto-lei passou a ser usado como fundamento para a dissolução de toda (e qualquer) associação que não se coadunasse com a linha de pensamento do governo. A própria exposição de motivos do supracitado Decreto-lei deixava claro o intuito de coibir a organização da sociedade civil, sendo asseverado que

[...] o novo regime, fundado em nome da Nação para atender às suas aspirações e necessidades, deve estar em contato direto com o povo, sobrê posto às lutas partidárias de qualquer ordem, independendo da consulta de agrupamentos, partidos ou organizações $[\ldots]^{128}$.

Com o final da Era Vargas e com a gradativa reabertura democrática no país, vislumbrou-se a possibilidade de se reafirmar a liberdade de associação. Entretanto, antes mesmo do advento da Constituição de 1946, foi editado o Decreto-lei nº 9.085 de 25 de março de 1946, que conferiu ao oficial de registro de pessoas jurídicas o poder de impedir administrativamente, e de forma preventiva, a personificação de sociedades e associações $^{129}$. Isso permitiu ao Poder Executivo ter amplo controle sobre a articulação da sociedade civil. As regras desse Decreto-lei, de alguma forma, foram convalidadas pelo

reconhecer as associações não personificadas. Ver, nesse sentido, LEONARDO, Rodrigo Xavier. As associações em sentido estrito...Op. cit., p.42-44.

${ }^{127}$ As associações civis eram regidas pelos artigos 20 a 23 do Código Civil de 1916 e complementadas pelos artigos 18 e 19, que disciplinavam o registro civil das pessoas jurídicas.

${ }^{128}$ Ibid., p. 47.

${ }^{129}$ Os artigos $2^{\circ}$ e $3^{\circ}$ do Decreto-lei $n^{\circ}$ 9.085/1946 determinam que "Não poderão ser registrados os atos constitutivos de pessoas jurídicas quando seu objeto ou circunstância relevante indique destino ou atividade ilícitos ou contrários, nocivos ou perigosos ao bem público, à segurança do Estado e da coletividade, à ordem pública ou social, à moral e aos bons costumes" (Artigo $2^{\circ}$ ) e "Ocorrendo qualquer dos motivos previstos no artigo anterior, o Oficial de Registro, ex-officio, ou por provocação de qualquer autoridade, sobrestará o processo de inscrição e suscitará dúvida [...]” (Artigo $3^{\circ}$ ). 
texto da Constituição de 1946 que, muito embora contemplasse a liberdade de associação nos mesmos moldes das anteriores, previu a proibição de registro e funcionamento de associações que atentassem contra a democracia (Artigo 141, $\S \S 12$ e $13^{130}$ ). Pode-se também dizer que a jurisprudência da época evidencia diversos exemplos da ingerência do Poder Executivo sobre as associações, citem-se como exemplos o cancelamento do registro do Partido Comunista do Brasil em 1947 e a suspensão do funcionamento da ordem religiosa das Testemunhas de Jeová em $1949^{131}$.

Se durante esse breve período democrático a liberdade de associação foi intensamente restringida e submetida ao crivo do Estado, com o golpe militar de 1964 que iniciou mais um longo período de sucessivos governos ditatoriais no país - essa garantia foi cerceada com muito mais vigor.

A Constituição de 1967 e Emenda n ${ }^{\circ} 1$ de 17 de outubro de 1969 garantiram a liberdade de associação, conquanto previssem também o mecanismo para que o Estado suprimisse tal garantia - consubstanciado na possibilidade de declaração do estado de sítio (artigo 152, §2 $2^{\circ}$, “d"132).

Na legislação infraconstitucional o poder de polícia do Estado sobre as entidades associativas se reafirmou através da nova Lei de Registros Públicos, que reeditou as regras dos artigos $2^{\circ}$ e $3^{\circ}$ do Decreto-lei $n^{\circ} 9.085 / 1946$ e ratificou o poder dos oficiais de registro, ex officio, de, preventivamente, impedirem a personificação de associações que “[...] indiquem destino ou atividades ilícitos, ou contrários, nocivos ou perigosos ao bem público, à segurança do Estado de coletividade, à ordem pública ou social, à moral e aos bons costumes” (artigo 115 da Lei ${ }^{\circ}$ 6.015/1973). Durante o período da ditadura militar a

\footnotetext{
${ }^{130}$ Artigo 141, §12 da Constituição Federal de 1946 - É garantida a liberdade de associação para fins lícitos. Nenhuma associação poderá ser compulsoriamente dissolvida senão em virtude de sentença judiciária. [...] $\S 13$ - É vedada a organização, o registro ou o funcionamento de qualquer Partido Político ou associação, cujo programa ou ação contrarie o regime democrático, baseado na pluralidade dos partidos e na garantia dos direitos fundamentais do homem.

${ }^{131}$ No caso do Partido Comunista do Brasil, a dissolução se deu através do processo de cancelamento de partido $n^{\circ} 411 / 412$ que tramitou no Tribunal Superior Eleitoral em 1947, tendo sido acolhido o pedido de cancelamento sob a alegação de que a agremiação desenvolveria atividades contrárias à democracia, professava ideologia estrangeira e recebia recursos do exterior. No caso da ordem das Testemunhas de Jeová (“Sociedade Torre de Vigia de Bíblias e Tratados"), o pedido de suspensão se deu pois considerou-se que a ordem promovia propaganda política de fundo anárquico. Em ambos os casos, e ainda em diversos outros, o procedimento era análogo: o Poder Executivo determinava a suspensão da associação por decreto. Em seguida, os órgãos de investigação vinculados a esse Poder justificavam a medida e, por fim, o Judiciário, com base nas provas colhidas e interpretadas pelo Executivo, confirmava a dissolução. (LEONARDO, Rodrigo Xavier. As associações em sentido estrito...Op. cit., p.53-54).

${ }^{132}$ Artigo 152, $\$ 2^{\circ}$ da Constituição Federal de 1967 com emenda no 1 de 17 de outubro de 1969 - O estado de sítio autoriza as seguintes medidas coercitivas: [...] d) suspensão da liberdade de reunião e de associação. Tal dispositivo foi repetido na Emenda Constitucional no 1 de 1969, no artigo 155, §2 , “d”.
} 
Lei de Registros Públicos foi aplicada em toda a sua extensão, fazendo com que os Oficiais de Registro fossem verdadeiros prolongamentos do governo que, nesse momento, tinha o interesse de coibir com rigor as organizações que lhe fossem, de alguma forma, prejudiciais. Essa norma é uma boa demonstração que a sociedade, de acordo com o momento histórico vivido, tem efeito direto na aplicação das leis, uma vez que continua vigente até hoje, nos mesmos termos, sem, no entanto, ser aplicada na extensão que lhe foi conferida anteriormente.

Apesar da menção expressa à liberdade de associação em praticamente todas as Constituições pátrias ao longo dos últimos dois séculos, é certo que o efetivo exercício desse direito, apesar de tolerado em determinados momentos - e sob determinadas condições -, não era fomentado ${ }^{133}$.

Esse panorama começou a se alterar com a queda da ditadura militar e a promulgação da Constituição de 1988, a qual garantiu não apenas a liberdade de associação como também assinalou que a criação dessas organizações não dependeria de autorização de qualquer natureza e que estava vedada a interferência estatal em seu funcionamento (artigo $5^{\circ}$, XVII e XVIII). A única vedação que subsistiu foi a proibição da associação para fins ilícitos e paramilitares, cujo controle de legalidade seria feito $a$ posteriori pelo Poder Judiciário. Foi nessa oportunidade, ainda, que se constitucionalizou a legitimidade ativa das associações para, mediante autorização, representar seus associados judicial e extrajudicialmente (Artigo $\left.5^{\circ} \mathrm{XXI}\right)^{134}$.

Em linhas gerais, é possível dizer que, atualmente, no Brasil e em grande parte das democracias ocidentais, vive-se um momento de promoção das atividades associativas, como centro de aglutinação dos mais diversos interesses da sociedade civil $^{135}$. O redimensionamento da relação entre a sociedade civil e o Estado contribuiu decisivamente para o fomento das associações, uma vez que, com o afastamento progressivo do

\footnotetext{
${ }^{133}$ LEONARDO, Rodrigo Xavier. As associações em sentido estrito...Op. cit., p. 56-57.

134 Diz-se que o artigo $5^{\circ}$, XXI, Constituição Federal de 1988 constitucionalizou a legitimidade para representação dos associados porque a legitimidade para a propositura da Ação Civil Pública já estava prevista na Lei $\mathrm{n}^{\circ} 3.747$ desde 1985 (artigo $5^{\circ} \mathrm{V}$ da referida lei). É possível afirmar que as duas disposições são complementares: a Lei da Ação Civil Pública legitimava as entidades associativas à propositura de ações na defesa dos direitos difusos e coletivos e, integrando o rol, a Constituição passou a autorizar a defesa dos direitos individuais dos associados mediante representação processual. Como se verá adiante, apenas com o advento do Código de Defesa do Consumidor é que as associações passaram a poder defender, também, direitos individuais homogêneos como substituto processual. Ver, nesse sentido, GRINOVER, Ada Pellegrini (et alli). Código Brasileiro de Defesa do Consumidor comentado pelos autores do anteprojeto. 8.ed. Rio de Janeiro: Forense Universitária, 2005, p. 820-823.

${ }^{135}$ LEONARDO, Rodrigo Xavier. As associações em sentido estrito...Op. cit., p.63.
} 
intervencionismo estatal, surgiu um espaço residual que não vem sendo ocupado pelos particulares - ou pelo mercado -, mas pela sociedade organizada ${ }^{136}$.

O papel das associações civis nessa nova configuração social é, portanto, fundamental. Elas não apenas são uma fiel expressão dos direitos fundamentais de terceira geração, enquanto se ocupam de reunir parcelas da sociedade propugnando interesses comuns, mas também desempenham função indispensável na implementação dos direitos fundamentais de segunda geração ${ }^{137}$. Isso porque mesmo sendo admitida uma redução do intervencionismo estatal, justificada por uma revisão da política do Welfare State, não é admissível que o Estado se abstenha de concretizar as políticas públicas indispensáveis ao bem estar social ${ }^{138}$; assim, a atuação das associações observa-se também na defesa, e na cobrança junto ao Estado, da realização de políticas públicas em favor de setores da sociedade com menor potencial de influência sobre as escolhas orçamentárias ${ }^{139}$.

A atribuição de legitimidade ativa às associações para a defesa em juízo dos interesses de seus associados e, ainda, dos direitos transindividuais, faz parte dessa conjuntura de fomento à articulação da sociedade civil por meio da reunião em entidades associativas. A opção legislativa pela atribuição de legitimidade ativa às associações foi uma forma de garantir a participação direta da sociedade na defesa dos interesses coletivos, considerando que entidades organizadas com uma finalidade comum teriam mais aptidão

136 SOMMA, Alessandro. Autonomia Privata. Rivista di diritto civile, Padova, ano XLVI, n. 4, 2000, p. 597-598.

137 Definindo as três gerações de direitos fundamentais, Alexandre de Moraes destaca que: "Os direitos fundamentais de primeira geração são os direitos e garantias individuais e políticos clássicos (liberdades públicas), surgidos institucionalmente a partir da Magna Charta" (MORAES, Alexandre de. Constituição do Brasil Interpretada e legislação constitucional. São Paulo: Atlas, 2008, p. 31). Referindo-se aos hoje chamados direitos fundamentais de segunda geração, que são os direitos sociais, econômicos e culturais, surgidos no inicio do século, Themistocles Brandão Cavalcanti analisou que [...] "Entre os direitos chamados sociais, incluem-se aqueles relacionados com o trabalho, o seguro social, a subsistência, o amparo à doença, à velhice etc" (CAVALCANTI, Themistocles Brandão. Princípios gerais do direito privado. 3.ed. Rio de janeiro: Borsoi ,1966. p. 202). Por fim, nos dias de hoje, protegem-se, constitucionalmente, como direitos de terceira geração os chamados direitos de solidariedade ou fraternidade, que englobam o direito a um meio ambiente equilibrado, uma saudável qualidade de vida, ao progresso, à paz, à autodeterminação dos povos e a outros direitos difusos, que são, no dizer de João Marcelo Vigliar, "[...] os interesses de grupos menos determinados de pessoas, sendo que entre elas não há vínculo jurídico ou fático muito preciso" (VIGLIAR, João Marcelo. In: MORAES, Alexandre de. Direito Constitucional. 9 ed.São Paulo: Atlas, 2005. p. 26-27. Concluindo a ideia, assinala Manoel Gonçalves Ferreira Filho: “A primeira geração seria a dos direitos de liberdade, a segunda, dos direitos de igualdade, a terceira, assim, complementaria o lema da Revolução Francesa: liberdade, igualdade, fraternidade" (FERREIRA FILHO, Manoel Gonçalves. Direitos Humanos Fundamentais. São Paulo: Saraiva, 1995, p. 57).

${ }^{138}$ Nas palavras de Rodrigo Xavier Leonardo (2006): “a redução do aparato burocrático decorrente de uma revisão do Welfare State, no entanto, não elimina suas funções nem tampouco a necessidade de políticas públicas que, noutro tempo, justificaram o crescimento do Estado” (LEONARDO, Rodrigo Xavier. As associações em sentido estrito...Op. cit., p.63).

139 FUSARO, Andrea. L'associazione non riconosciuta: modelli normativi ed esperienze atipiche. Padova: Cedam, 1991. 
para o desempenho dessa função do que os cidadãos individualmente considerados - um dos motivos pelos quais não se positivou em nosso ordenamento jurídico, como adiante se verá, a legitimidade ativa individual para a propositura de ações coletivas ${ }^{140}$.

O momento histórico, portanto, é favorável ao surgimento das associações civis. $\mathrm{O}$ ambiente é extremamente propício e o legislador se preocupou em conferir diversas vantagens às entidades associativas para estimular essa articulação dos grupos, vantagens essas que vão desde a imunidade tributária para associações de assistência social (artigos 150, VI, “c” e 195, $\$ 7^{\circ}$ da Constituição Federal ${ }^{141}$ ) até a isenção do pagamento de custas e demais encargos da sucumbência em ações coletivas por elas propostas (artigo 18 da Lei $\mathrm{n}^{\circ}$ 7.347/1985 e artigo 87 do Código de Defesa do Consumidor) ${ }^{142}$.

Esses incentivos, no entanto, podem resultar em uma indesejada proliferação de associações que não buscam a defesa dos interesses da sociedade ou de seus associados, tampouco visam promover a participação dos indivíduos nos processos decisórios, mas sim procuram somente obter vantagens para os seus dirigentes ou para um determinado grupo de associados. Essas manifestações patológicas da liberdade de associação e a máutilização das benesses concedidas pela lei às entidades associativas serão analisadas com maior vagar nos capítulos 6 e 7 deste estudo, especialmente no que diz respeito à legitimidade ativa dessas entidades para a propositura de ações coletivas. É certo que tais práticas deverão ser coibidas, visto que disso depende a manutenção, efetividade e credibilidade do sistema de proteção aos interesses transindividuais.

Uma democracia sólida e madura, que tem como base o respeito à pluralidade social do país, está apoiada, entre muitas outras coisas, na liberdade de associação - não mais se admitindo, como em outras épocas, que essa garantia seja restringida

\footnotetext{
${ }^{140}$ Essa opção legislativa deve-se, entre outras coisas, à ausência da positivação dos requisitos para verificação da representatividade adequada, como assinalam os autores do anteprojeto que deu origem ao Código de Defesa do Consumidor: “[...] não se chegou ao ponto de legitimar a pessoa física às ações coletivas, talvez pela insegurança gerada pela falta de norma expressa sobre a aferição, pelo juiz, da 'representatividade adequada'. [...] Contudo, além do norte-americano, diversos ordenamentos iberoamericanos legitimam às ações coletivas do ‘cidadão' [...]” (GRINOVER, Ada Pellegrini (et alli). Código Brasileiro de Defesa do Consumidor comentado...Op. cit., p. 788.

${ }^{141}$ Artigo 150 - Sem prejuízo de outras garantias asseguradas ao contribuinte, é vedado à União, aos Estados, ao Distrito Federal e aos Municípios: [...]VI - instituir imposto sobre: c) patrimônio, renda ou serviços dos partidos políticos, inclusive suas fundações, das entidades sindicais dos trabalhadores, das instituições de educação e de assistência social, sem fins lucrativos, atendidos os requisitos da lei.

Artigo 195 [...] $\$ 7^{\circ}$ - São isentas de contribuição para a seguridade social as entidades beneficentes de assistência social que atendam às exigências estabelecidas em lei.

${ }^{142}$ Artigo 18 da Lei $n^{\circ} 7.347 / 1985$ - Nas ações de que trata esta lei, não haverá adiantamento de custas, emolumentos, honorários periciais e quaisquer outras despesas, nem condenação da associação autora, salvo comprovada má-fé, em honorários de advogado, custas e despesas processuais.

O artigo 87 do Código de Defesa do Consumidor tem exatamente a mesma redação.
} 
preventivamente $^{143}$. Por outro lado, não se deverá admitir que, em nome de uma liberdade de associação irrestrita, alguns entes associativos se valham de uma pretensa defesa de interesses coletivos para obter vantagens indevidas.

\subsection{AS ASSOCIAÇÕES CIVIS NA LEGISLAÇÃO BRASILEIRA EM VIGOR: DA CONSTITUIÇÃO À EFETIVA ATUAÇÃO NA DEFESA DOS INTERESSES TRANSINDIVIDUAIS}

Muito embora seja certo que as normas que disciplinam as associações civis no Brasil permearão todo o texto dessa dissertação, é importante descrever o arcabouço legislativo, atualmente em vigor, que regula as entidades associativas desde sua constituição, passando pela organização de seus órgãos deliberativos e administrativos, até o momento em que se tornam aptas a acessar o poder judiciário para atuar na defesa dos direitos transindividuais.

Tal análise será feita sob o prisma cronológico, verificando-se a legislação pátria atual sobre o tema, com o objetivo de obter uma visão mais precisa da forma como o legislador reagiu e tem reagido às necessidades da sociedade em termos de organização. Como ponto de partida, adotou-se o ano de 1973, em que foi promulgada a Lei $\mathrm{n}^{\mathbf{o}}$ 6.015/1973 (Lei de Registros Públicos), a lei mais antiga que disciplina associações e que ainda está vigente.

Desde o Código Civil de 1916, vigente em 1973, o legislador vem repetindo que a existência das pessoas jurídicas de direito privado - entre elas as associações - inicia-se com a inscrição de seus atos constitutivos no seu registro peculiar, regulado por lei especial (artigo 18 do Código Civil de 1916). A regra é reafirmada no artigo 119 da Lei de Registros Públicos (Lei n 6.015/1973) e transposta, sem grandes alterações, para o Código Civil de 2002 (artigo 45), de modo que o registro da associação continua sendo indispensável para a personificação da entidade. No caso, é a Lei de Registros Públicos - a primeira entre as que disciplinam a vida associativa e que continuam em vigor nos dias de hoje - que dispõe sobre as peculiaridades desse registro.

O inciso I do artigo 114 da Lei de Registros Públicos dispõe que serão inscritos no Registro Civil de Pessoas Jurídicas os atos constitutivos e estatutos "das sociedades civis, religiosas, pias, morais, científicas, ou literárias, bem como o das fundações e das

${ }^{143}$ LEONARDO, Rodrigo Xavier. As associações em sentido estrito...Op. Cit., p.78-80. 
associações de utilidade pública", tendo o artigo 120 da mesma lei mencionado o registro das "sociedades, fundações e partidos políticos" apenas. Vê-se, pois, que a lei não usa a denominação associação - senão para caracterizar as associações de utilidade pública. Essa imprecisão pode ser atribuída à fidelidade do legislador de 1973 aos ditames do Código Civil de 1916, que não diferenciavam de forma clara as sociedades e as associações civis, defeito esse que não subistiu à entrada em vigor do Código Civil de 2002. Por esse motivo, o registro de contratos, de atos constitutivos, estatutos ou compromissos, tanto das associações como das sociedades e suas alterações, são registráveis na forma dos artigos 114 a 121 da Lei de Registros Públicos ${ }^{144}$.

Desde essa época, a doutrina tem divergido quanto à necessidade do registro da associação, e sua consequente personificação, para a atuação da entidade de forma judicial e extrajudicial. Há uma parte da doutrina que defende que a atuação da associação está adstrita à sua constituição nos termos da lei civil ${ }^{145}$ - que preconiza o registro dos estatutos - e, por outro lado, outra parte da doutrina assinala que “[...] a constituição legal da associação não pode ser confundida com o registro dos estatutos que [...] sob uma

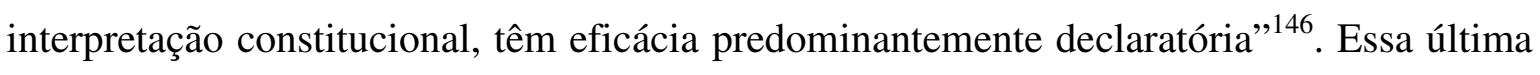
parcela da doutrina afirma que as associações não registradas são tão legítimas para a defesa dos interesses coletivos em juízo quanto aquelas que levaram seus estatutos a registro - uma vez que a legitimidade é atribuída a essas entidades por sua disponibilidade para representar adequadamente e de forma eficiente os interesses do grupo ${ }^{147}$.

\footnotetext{
${ }^{144}$ CENEVIVA, Walter. Lei dos Registros Públicos comentada. 16. ed.São Paulo: Saraiva, 2005, p. 254.

${ }^{145}$ Nesse sentido, assinala Raphael de Barros Monteiro Filho: "A questão que se poderia colocar a respeito desse requisito, chamado pelo legislador de requisito da pré-constituição, é a de saber se o que a lei dispensa é apenas o lapso temporal ou, bem mais que isso, é a própria personalização. Ou, por outras palavras, poderia uma associação irregular ou de fato dedicada à defesa do meio ambiente ou interesses dos consumidores, por exemplo, ser aceita como legitimada àquelas ações? A resposta é, evidentemente, a negativa [...]. Está claro, a propósito, que o requisito que pode ser dispensado pelo juiz é aquele que antes foi posto pelo próprio legislador, além do que nem teriam sentido a promoção da defesa de graves interesses sociais e o estímulo ao associativismo, pretendidos pelo legislador, através de entidades formadas ao arrepio da lei" ((TEIXEIRA, Sálvio de Figueiredo (coord.). Comentário ao Novo Código Civil. Volume I. Rio de Janeiro: Forense, 2010, p. 265-266). Nesse mesmo sentido, ver também Nelson Nery Jr. e Rosa Maria de Andrade Nery, para os quais "A associação deve estar constituída de acordo com o CC 53 a 61 (v. CC/1916 20 a 23) e seus estatutos devidamente registrados no registro civil de pessoas jurídicas (CC 45 e 985; CC/1916 18, LRP 114, I)" (NERY JR., Nelson; NERY; Rosa Maria de Andrade. NERY JR., Nelson; NERY; Rosa Maria de Andrade. Código Civil Comentado.São Paulo: Ed. Revista dos Tribunais: 2006, p. 247). Ver também: MANCUSO, Rodolfo de Camargo. Ação Civil Pública, em defesa do meio ambiente, do patrimônio cultural e dos consumidores. São Paulo: Ed. RT, 2004.

${ }_{146}^{4}$ LEONARDO, Rodrigo Xavier. As associações em sentido estrito...Op. cit., p. 207.

${ }^{147}$ Nesse sentido ver BARBOSA MOREIRA, José Carlos. Tutela jurisdicional dos interesses coletivos ou difusos. Revista de Processo, São Paulo, ano X, n.39, jul/set 1985, p. 59.
} 
Para fins desse estudo, adotou-se a orientação que dispensa o registro dos estatutos e, com isso, a personificação, como requisito de existência da entidade associativa. O negócio jurídico associativo, consubstanciado nos estatutos da associação, existe e vale desde o momento de sua constituição - o que habilita a entidade à prática de todos os atos que lhe permite a legislação é a propositura de ações coletivas. Sobre o tema, veja-se o magistério de Marcos Bernardes de Mello:

\begin{abstract}
Os contratos sociais e demais atos constitutivos relativos a sociedades, sejam civis em sentido estrito (sociedades simples, associações e fundações de direito privado), sejam empresariais não têm o efeito de criar a pessoa jurídica. Antes da inscrição no registro próprio (as sociedades simples [=meramente civis], as associações e as fundações privadas são registradas no Registro Civil das Pessoas Jurídicas, enquanto as empresas, no Registro Público de Empresas Mercantis), existe a sociedade, a associação ou a fundação, mas sem personalidade jurídica. Sua eficácia se restringe às relações dos sócios entre si e, eventualmente, com terceiros. A personificação é exclusiva eficácia do registro, ao contrário das pessoas físicas, em relação às quais o registro tem mero caráter declarativo, sem qualquer efeito constitutivo da personalidade. ${ }^{148}$
\end{abstract}

$\mathrm{Na}$ doutrina estrangeira também são encontrados exemplos dessa orientação, cabendo especial menção a José de Oliveira Ascenção, o qual assinala que, em Portugal, a personalidade jurídica é reconhecida automaticamente, mas vai além, ressaltando que "nenhum reconhecimento se dá fora do preenchimento da fatispécie legal e das suas limitações" $" 149$ - de modo que, como será detalhado posteriormente, a atuação das entidades é que determinará seu enquadramento nos termos da lei e, com isso, sua caracterização como associação.

Dentre os diplomas legais que continuam vigentes e compondo o quadro normativo que disciplina as associações, o primeiro que abordou a capacidade específica das associações de estar em juízo foi a Lei da Ação Civil Pública (Lei no 7.347/1985) editada ainda sob a égide da Constituição Federal de 1967 e da Emenda Constitucional n ${ }^{\circ} 1$ de

148 BERNARDES DE MELlO, Marcos. Teoria do fato jurídico: plano da eficácia. 2.ed. São Paulo: Saraiva, 2004, p. 160. No mesmo sentido, ver Pontes de Miranda sobre a personificação de sociedades - cuja disciplina, no que não for conflitante, pode ser aplicada às associações -, dizendo que "O contrato de sociedade, feito por instrumento público ou por instrumento particular, existe e, formalmente, vale; o que se dá é que (ainda) não tem eficácia contra terceiros". (PONTES DE MIRANDA. Tratado de Direito Privado. 3. ed. tomo XLIX. Rio de Janeiro: Borsoi, 1970, p. 65-66). Concordando com essa orientação, ainda, atesta Sylvio Marcondes que "[...] a sociedade, acordo de vontades apto a constituir direitos subjetivos, é negócio jurídico, apto a produzir efeitos imediatos, de caráter societário e independentes de que ela adquira, ou não, personalidade jurídica”. (MARCONDES, Sylvio. Problemas de Direito Mercantil. São Paulo: Max Limonad, 1970, p. 144-145). Ver também FRANÇA, Erasmo Valladão Azevedo e Novaes. Temas de direito societário, falimentar e teoria da empresa. São Paulo:Malheiros, 2009, p. 554-555.

149 ASCENÇÃO, José de Oliveira. Direito Civil: Teoria Geral. vol.1. 3. ed. São Paulo: Saraiva:2010, p. 238. 
1969 e do Código Civil de 1916. Por esse motivo, considerou-se vanguardista a posição da Lei da Ação Civil Pública que, ainda em um cenário legislativo em que a liberdade de associação e a forma de organização das entidades associativas eram parcamente regulamentadas, conferiu às associações civis a legitimidade ativa para a propositura de ações civis públicas na defesa de interesses difusos e coletivos ${ }^{150}$.

$\mathrm{O}$ artigo $5^{\circ}$, incisos I e II, constante da redação original da Lei da Ação Civil Pública, alçou às associações a qualidade de representantes da sociedade civil na defesa dos interesses transindividuais, como legitimadas à propositura de ações civis públicas, colocando-as ao lado do Ministério Público e dos entes políticos. Desde a primeira redação do artigo $5^{\circ}$ da Lei $n^{\circ} 7.347 / 1985$, constaram requisitos objetivos para a atribuição de legitimidade ativa às associações, no caso, a constituição há mais de um ano nos termos da lei civil e a inclusão entre suas finalidades institucionais da defesa dos interesses difusos e coletivos abarcados pela lei.

Tal dispositivo vigora, até hoje, com poucas alterações. A legitimidade das associações civis foi ressaltada e revigorada ao longo das diversas emendas realizadas na Lei da Ação Civil Pública nas últimas duas décadas, constando hoje no mesmo artigo $5^{\circ}$, inciso V, alíneas "a" e "b" da Lei n $n^{\circ} 7.347 / 1985$. As reformas da Lei n 7.347/1985 foram levadas a cabo nos anos de 1990, 1994, 2001 e 2007, em todos os casos visando à compatibilização dos dispositivos dessa lei com outros diplomas legais que, gradativamente, entravam em vigor ou passavam por reformas e com isso afetavam a disciplina das ações civis públicas ${ }^{151}$.

A alteração legislativa seguinte à entrada em vigor da Lei da Ação Civil Pública foi de monta. Tratou-se da promulgação da Constituição Federal de 1988, que teve papel determinante na forma como as associações civis são tratadas pela sociedade e pela

\footnotetext{
${ }^{150}$ Conforme constou da primeira redação do artigo $1^{\circ}$ da Lei $\mathrm{n}^{\circ} 7.347 / 1985$, a defesa de tais interesses resumia-se à responsabilização por danos morais e patrimoniais causados ao Meio Ambiente; ao consumidor; a bens e direitos de valor artístico, estético, histórico, turístico e paisagístico; e a qualquer outro interesse difuso ou coletivo (Artigo $1^{\circ}$, I a IV). O inciso IV, que se referia a todos os demais interesses difusos e coletivos, foi vetado por questões que diziam respeito à segurança jurídica - considerou-se a locução muito ampla e passível de criar divergências interpretativas pouco saudáveis para o sistema. Na mensagem de veto, foi assinalado que hipóteses não abarcadas por aquelas previsões legais, e que fossem "ditadas pela complexidade da vida social" seriam oportunamente reguladas pelo legislador. Nesse sentido, ver a mensagem de veto à lei ${ }^{\circ} 7.347 / 1985$.

${ }^{151}$ Notadamente, nesse sentido, a entrada em vigor da Constituição Federal de 1988, do Código de Defesa do Consumidor (Lei ${ }^{\circ}$ 8.078/1990), a reforma do Código de Processo Civil em 1994 e a entrada em vigor do Novo Código Civil de 2002 (Lei no 10.406/2002) determinaram a realização de ajustes na Lei da Ação Civil Pública com o intuito de compatibilizá-la aos novos contornos da legislação pátria. Nenhuma alteração, no entanto, foi substancial o suficiente para alterar as bases sobre as quais se construiu a disciplina das ações civis públicas, que continuaram se remetendo à Lei $\mathrm{n}^{\circ} 7.347 / 1985$.
} 
legislação atualmente, uma vez que se ocupou da constitucionalização da importância de tais entidades.

O progresso em relação à Constituição anterior - que se limitava a mencionar a liberdade de associação e as hipóteses em que essa liberdade poderia ser cerceada refletiu, em alguma medida, a tendência inaugurada pela Lei da Ação Civil Pública. A Constituição Federal de 1988, para além de garantir a liberdade de associação, livre de intervenção do Estado em sua constituição ou dissolução (artigo $5^{\circ}$, incisos XVII, XVIII e XIX), consagrou como direito fundamental a legitimidade das entidades associativas para a representação judicial e extrajudicial dos interesses de seus associados (artigo $5^{\circ}$, inciso XXI) e para a impetração de mandado de segurança coletivo (artigo 5o, inciso LXX, "b"). Conforme se verá adiante, em capítulo próprio acerca da legitimidade ativa das associações, a ideia do dispositivo constitucional não foi limitar a atuação das associações à representação processual dos seus associados, mas acrescer essa faceta da legitimidade ativa à substituição processual preconizada pela Lei no 7.347/1985.

A liberdade de associação e a importância dessas entidades não foram positivadas apenas entre os direitos fundamentais. $\mathrm{O}$ fomento às associações como forma legítima de manifestação da sociedade civil foi arrolado como princípio geral atinente à manutenção da ordem econômica e financeira do Estado brasileiro, tendo a Constituição Federal previsto que uma das funções do Estado é apoiar e estimular, por meio da legislação, o associativismo (artigo 174, $\S 2^{\circ}$ da Constituição Federal) ${ }^{152}$. Ressalta o constituinte, ainda, a autonomia de organização e funcionamento das associações de caráter desportivo - mais uma vez assinalando o papel do Estado como promotor dessas atividades (artigo 217, I da Constituição Federal).

A referência ao importante papel das associações no texto constitucional desencadeou uma resposta do legislador que se fez sentir na legislação infraconstitucional. Ao longo da década de 90, ainda sob a égide do Código Civil de 1916 - que, como visto,

\footnotetext{
${ }^{152}$ Entende-se, nesse tocante, que o constituinte tenha mencionado no artigo 174, §2 ${ }^{\mathrm{a}}$ da Constituição Federal de 88 que o papel da lei será de apoio e fomento ao associativismo para evitar que a menção à figura do Estado, diretamente, apontasse para algum tipo de intervencionismo subvencionado pelo texto constitucional. De todo modo, sobre a inclusão do fomento às associações neste trecho da constituição, assevera Kazuo Watanabe "Foi justamente objetivando a formação dessa sociedade mais solidária e justa que a Constituinte procurou estimular a criação de associações (incs. XVII, XVIII, XIX, XX e XXI, do art.5 $5^{\circ}, \mathrm{CF}$ ), e no Capítulo da Ordem Econômica e Financeira estabeleceu a defesa do consumidor como um dos princípios em que se assenta a atividade econômica do país (art. 170, V, CF) e declarou, expressamente, que "a lei apoiará e estimulará o cooperativismo e outras formas de associativismo" (art. 174, §2, CF)" (GRINOVER, Ada Pellegrini (et alli). Código de Defesa do Consumidor comentado...Op. Cit., p. 821.)
} 
não disciplinava a vida das entidades associativas de forma detalhada ou diferenciada de outras pessoas jurídicas de direito privado - entraram em vigor diversas leis sobre o tema. Algumas delas se prestaram a reforçar o papel do Estado no fomento das atividades associativas e a reafirmar a legitimidade dessas entidades para a defesa de direitos transindividuais; outras pretenderam suprir a falta de regulamentação específica do Código Civil de 1916, pois atribuíam às associações benefícios que não poderiam ser auferidos por outras pessoas jurídicas.

Essa tendência a regular o papel e a atuação das associações foi inaugurada com a entrada em vigor do Código de Defesa do Consumidor (Lei $\mathrm{n}^{\mathrm{o}}$ 8.078/1990) ${ }^{153}$. Esse diploma legal foi um marco na legislação de proteção aos direitos individuais na sociedade de consumo, em que as relações jurídicas entre fornecedores e consumidores não mais se encontram em uma posição de equilíbrio ${ }^{154}$. A concentração da produção de bens e serviços e sua massificação criaram um ambiente propício ao desenvolvimento da desigualdade informativa - e, por vezes, também econômica -, deixando o consumidor em uma posição de vulnerabilidade. Esse diploma legal tem como um de seus objetivos maiores reequilibrar, na medida do possível, as relações de consumo de uma forma que o mercado, por ele mesmo, teria dificuldade em fazer ${ }^{155}$. E as formas de operacionalizar esse projeto passam pela reafirmação da igualdade substancial, pelo fortalecimento da

\footnotetext{
${ }^{153}$ As bases constitucionais da legislação de proteção aos consumidores foram lançadas pela Constituição Federal de 1988 que, em seu artigo 5º XXXII, estabeleceu: “O Estado promoverá, na forma da lei, a defesa do consumidor". O constituinte, nesse caso, foi além do texto programático do artigo supracitado e estabeleceu, no artigo 48 do Ato de Disposições Constitucionais Transitórias, que "o Congresso Nacional, dentro de cento e vinte dias da promulgação da Constituição, elaborará o Código de Defesa do Consumidor". Ver, nesse sentido, GRINOVER, Ada Pellegrini (et alli). Código de Defesa do Consumidor comentado... Op. cit., p. 8.

${ }^{154}$ Reinhard Zimmermann esclarece que a proteção aos direitos dos consumidores é uma manifestação moderna da proteção dos interesses das partes mais fracas: "[...] the law pursues a typological approach: it attemps to grant protection to one contracting party who is considered to be in a weaker position, or at a specific disadvantage, via-à-vis the other.

Consumer protection is thus a modern manifestation of a much broader concern. The tradition of legislation protecting weaker parties against disadvantageous contract terms has a long pedigree; it reaches back to the maximum interest rates for loans, the senatus consultum Vellaenum, and the laesio enormis of Roman law." (tradução livre: [...] a lei traz uma abordagem tipológica: ela tenta garantir a proteção da parte no contrato considerada em uma posição de fragilidade ou que tenha uma desvantagem específica em relação à outra. A proteção ao consumidor é, por isso, uma manifestação de uma preocupação muito mais ampla. A tradição da legislação protegendo as partes mais fracas contra desvantagens contratuais vem de longa data, vem desde a limitação das taxas de juros para empréstimos estabelecidas pelo senatus consultum Valleanum e a ideia de lesão enorme do direito romano.) (ZIMMERMANN, Reinhard. The new German Law of obligations: historical and comparative perspectives. Oxford: Oxford University Press, 2010, p. 161).

${ }^{155}$ GRINOVER, Ada Pellegrini (et alli). Código de Defesa do Consumidor comentado...Op. cit., p. 6-8.
} 
sociedade civil organizada em entes independentes do Estado e do mercado e pela ampliação do acesso à justiça ${ }^{156}$.

As associações civis foram classificadas pelo Código de Defesa do Consumidor como elementos de vital importância para a consecução desses objetivos. Logo no capítulo II, do referido Código, foi criada a "Política Nacional de Relações de Consumo" que, nos termos da própria lei,

[...] tem por objetivo o atendimento das necessidades dos consumidores, o respeito à sua dignidade, saúde e segurança, a proteção de seus interesses econômicos, a melhoria da sua qualidade de vida, bem como a transparência e harmonia das relações de consumo [...] (artigo $4^{\circ}$ da Lei $\left.n^{\circ} 8.078 / 1990\right)$.

Dentre os mecanismos previstos para a concretização da citada política está a ação governamental no sentido de proteger efetivamente o consumidor por meio do incentivo à criação e ao desenvolvimento das associações representativas (artigo 4 ', II, "b", e 5 , V, da Lei $\mathrm{n}^{\circ} 8.078 / 1990^{157}$ ).

No que tange ao acesso à justiça, foi reafirmada no Código de Defesa do Consumidor a legitimidade ativa das associações civis - no caso, especificamente, daquelas que declinassem em seus estatutos a finalidade de defesa do consumidor - para a defesa judicial dos direitos difusos, coletivos e individuais homogêneos (artigo 82, IV, da Lei $\left.\mathrm{n}^{\circ} 8.078 / 1990\right)$ por meio de todos os meios disponíveis e capazes de propiciar sua efetiva tutela (artigo 83 da Lei $\left.n^{\circ} 8.078 / 1990\right)$ ).

A evolução ensejada pela Lei da Ação Civil Pública, que primeiro dispôs sobre a legitimidade das associações civis para a defesa dos interesses transindividuais, dá-se no aumento do espectro desses direitos, notadamente pela positivação da possibilidade de defesa dos interesses individuais homogêneos - muito comuns nas relações de consumo,

\footnotetext{
156 Ver, nesse sentido, Ada Pellegrini Grinover: "O reconhecimento e a necessidade de tutela desses interesses puseram em relevo sua configuração política. Deles emergiram novas formas de gestão da coisa pública, em que se afirmaram os grupos intermediários. Uma gestão participativa, como instrumento de racionalização do poder, que inaugura um novo tipo de descentralização, não mais limitada ao plano estatal (como a descentralização político-administrativa), mas estendida ao plano social, com tarefas atribuídas aos corpos intermediários e às formações sociais, dotados de autonomia e de funções específicas. Trata-se de uma nova forma de limitação ao poder do Estado, em que o conceito unitário de soberania, entendida como soberania absoluta do povo, delegada ao Estado, é limitado pela soberania social atribuída aos grupos naturais e históricos que compõe a nação" (GRINOVER. Ada Pellegrini. Significado social, político e jurídico da tutela...Op. cit., p. 10).

${ }^{157}$ Art. $5^{\circ}$ Para a execução da Política Nacional das Relações de Consumo, contará o poder público com os seguintes instrumentos, entre outros: [...] V - concessão de estímulos à criação e desenvolvimento das Associações de Defesa do Consumidor.
} 
mas também observável em casos de dano ambiental, dano ao patrimônio público, etc. ${ }^{158}$. Além disso, até o advento do Código de Defesa do Consumidor, os direitos transindividuais só podiam ser tutelados por meio de Ação Civil Pública. Após a entrada em vigor do diploma consumerista, possibilitou-se a efetivação dessa tutela pelas associações ou por qualquer um dos outros legitimados - por quaisquer meios disponíveis e aptos para tanto ${ }^{159}$.

Conquanto o avanço introduzido pelo Código de Defesa do Consumidor na disciplina das associações tenha sido notável, as regras do Código Civil de 1916 que dispunham sobre a criação de entidades associativas, e mesmo acerca dos requisitos mínimos para que determinada pessoa jurídica de direito privado fosse reconhecida como associação, ainda eram pouco específicas, o que inviabilizava uma diferenciação precisa ${ }^{160}$. Assim, as estratégias de fomento às associações intentadas pelo Poder Público conviviam com riscos consideráveis, entre eles o de que entidades pouco comprometidas com a defesa e a efetivação dos direitos transindividuais acabassem por fazer uso de incentivos do Estado - alguns deles expressos, inclusive, em transferência de valores em dinheiro em benefício dos seus integrantes e em detrimento da sociedade civil.

Por esse motivo, visando suprir a lacuna até então existente na legislação - quanto aos requisitos que deveriam ser atendidos por entidades que se denominam associações - e criar um ambiente mais seguro para o incentivo direto e o investimento do Poder Público, foram editadas as Leis $n^{\circ}$ 9.637/1998 e 9.790/1999. Esses diplomas legais abordam os requisitos que devem estar presentes nas pessoas jurídicas de direito privado para que essas possam ser consideradas "organizações sociais" ou "organizações da sociedade civil de

\footnotetext{
${ }^{158}$ Conforme assinalado no Capítulo 2, os direitos individuais homogêneos são aqueles de titularidade exclusiva do indivíduo, que poderia ser pleiteado individualmente mas que, devidoà sua homogeneidade $\mathrm{e}$ origem comum - de fato ou de direito - pode ser tutelado coletivamente pelos legitimados ativos eleitos pela lei. Essa possibilidade de tutela nasceu com a entrada em vigor do Código de Defesa do Consumidor. Antes disso, somente os direitos coletivos e difusos eram passíveis de tutela coletiva. Ver GRINOVER, Ada Pellegrini (et alli). Código de Defesa do Consumidor comentado...” Op. Cit., p. 867.

${ }^{159}$ Tal dispositivo veio para assegurar que as providências judiciais passíveis de defender os interesses individuais e coletivos - dos consumidores não estariam circunscritas a uma interpretação limitativa do artigo 75 do Código Civil de 1916, que preconizava que "a todo direito corresponde uma ação que o assegura". Nas palavras de Rizzatto Nunes "[...] estão garantidas todas as espécies de ações cabíveis: de conhecimento (declaratória, constitutiva, condenatória); cautelares; mandamentais; execuções; ação coletiva e ação civil pública; habeas corpus e etc" (NUNES, Rizzatto. Comentários ao Código de Defesa do Consumidor. 2. ed. Reformulada. São Paulo: Saraiva, 2006, p. 739).

${ }^{160}$ Destacam comentaristas do Código Civil que "A codificação revogada, ao contrário da vigente, não distinguia com clareza as duas corporações [sociedades e associações] e não detalhava o regime jurídico das associações. [...] Esse tratamento, de qualquer forma, mostrou-se deficiente e foi a causa maior da dificuldade que então havia para, em casos limítrofes, caracterizar certa corporação como desta ou daquela classe" (Ver MONTEIRO FILHO, Raphael de Barros. In: TEIXEIRA, Sálvio de Figueiredo (coord.). Comentários ao Novo Código Civil. Vol. I. Rio de Janeiro: Forense, 2010, p. 873.
} 
interesse público" e, como tais, sejam capazes de desfrutar de alguns benefícios, como privilégios fiscais, percepção de auxílios e subvenções da União Federal e de autarquias, entre outros ${ }^{161 \text { e } 162}$.

Ainda que os requisitos estabelecidos em tais leis não sejam pressupostos para a personificação ou atuação de todas as associações, servindo apenas para que as associações possam fazer jus a determinados benefícios legalmente concedidos às entidades que realizem tipos específicos de atividade - análogas à atuação estatal -, fixaram-se alguns parâmetros mínimos para a elaboração dos estatutos e para o comportamento das entidades, especialmente no que se refere à escolha de finalidades institucionais e organização interna para a consecução desses fins, que poderiam servir de base para a estruturação de qualquer associação.

Entre esses requisitos mínimos foi destacada, em primeiro plano e como característica mais importante, a ausência de finalidades lucrativas - que vai além da ausência de finalidades econômicas -, sendo vedada a distribuição, entre os integrantes das associações, de valores ou parcelas do patrimônio da entidade, que devem, obrigatoriamente, ser reaplicados na realização da atividade por ela desenvolvida ${ }^{163}$. Nesse sentido, determinou-se que constassem do estatuto da associação sua natureza social e os objetivos relativos à respectiva área de atuação. Evidentemente, ao se determinar tais alterações, regulou-se não apenas o estatuto das associações, mas também suas atividades. No que se refere à organização interna, essas leis determinaram a indispensabilidade de órgãos deliberativos e diretivos, cujo modo de funcionamento deve ser regulado pelo estatuto social da associação.

A evolução legislativa das normas que regulam as associações, portanto, traduziu não apenas os anseios da sociedade quanto à necessidade de regulamentar de forma mais sólida os agrupamentos de pessoas que se colocariam como seus representantes, mas,

${ }^{161}$ LEONARDO, Rodrigo Xavier. A associação em sentido estrito...Op. cit., p. 115, assinala, ainda, em outra oportunidade, que essas leis são partes muito importantes do tratamento do tema do terceiro setor no ordenamento jurídico brasileiro e deixam claras algumas opções legislativas que acabaram por inspirar a disciplina das associações no novo Código Civil e suas reformas. Ver nesse sentido LEORNARDO, Rodrigo Xavier. A reforma do direito das associações sem fins econômicos pela Lei $\mathrm{n}^{\circ} 11.127$ de 2005 e o terceiro setor. Revista de Direito do Terceiro Setor, Belo Horizonte: Editora Fórum, ano 1, n.1, jan-jun 2007, p. 3941.

${ }^{162}$ Em contrapartida, esses incentivos implicam uma maior fiscalização do Estado nas atividades das associações - sem que isso implique a adoção de práticas restritivas a liberdade de associação -, justamente com o fito de verificar a boa utilização dos bens alocados para a realização das finalidades das entidades. Bem por isso, as leis preveem a obrigatoriedade da publicação de relatórios financeiros (artigo $2^{\circ}$, I, " $\mathrm{f}$ ", da Lei $\mathrm{n}^{\circ}$ 9.637/1998), a presença de representantes do Poder Público nos quadros diretivos da entidade (artigo $3^{\circ}$, I, "a", da Lei no 9.637/1998), entre outras medidas da mesma natureza.

${ }^{163}$ Artigo 2a , I, "b", da Lei no 9.637/1998 e artigo $1^{\circ}, \S 1^{\circ}$ da Lei no 9.790/1999. 
também, evidenciou a dificuldade do próprio Estado em cumprir as estratégias de fomento a essas manifestações sociais, sem que se pudesse ter certeza da exata caracterização da entidade. Tal processo culminou com a profunda mudança da disciplina das pessoas jurídicas de direito privado com a entrada em vigor do Código Civil de 2002, ao qual as associações deveriam ter se adaptado até 11 de janeiro de 2007 (artigo 2.031 do Código Civil de 2002, conforme alterado pela Lei $\mathrm{n}^{\mathrm{o}}$ 11.127/2005).

O novo diploma civil operou, em primeiro plano, um afastamento não apenas conceitual, mas também topológico da disciplina que regulava as associações e as sociedades - conservando os artigos que tratam das associações sob o título de "pessoas jurídicas de direito privado", na parte geral do Código, e apartando as regras concernentes às sociedades em livro e título próprio (Livro II - Do Direito de Empresa; Título II - Da Sociedade). É possível dizer que o Código Civil de 2002 aperfeiçoou o disposto no Código Civil de 1916:

\begin{abstract}
[...] seja por conceituar com maior precisão o que sejam associações, extremando-as seguramente das sociedades, empresárias ou não, seja por oferecer um padrão mínimo de requisitos próprios dessas entidades, ou um modelo de regras estatutárias mínimas, de observância obrigatória e exclusiva delas, isto é, um modelo que não se aplica às sociedades, fundações, organizações religiosas e partidos políticos, a não ser em caráter subsidiário (art. $44, \S 2^{\circ}$ do novo Código Civl) ${ }^{164}$.
\end{abstract}

As normas contidas nos artigos 53 ao 60 do Código Civil de 2002 tratam da forma das associações: seus requisitos; a maneira como devem ser organizadas; os elementos básicos dos estatutos; as regras de interação entre associados e do relacionamento entre eles e as associações. $\mathrm{O}$ artigo 53 trata das características fundamentais, que integram o conceito de associação - presente na legislação desde o Código Civil de 1916. O artigo 54, por sua vez, inova ao pormenorizar em seus incisos o conteúdo mínimo dos estatutos das associações, que deve estar presente sob pena de nulidade ${ }^{165}$. Como o estatuto é um elemento constitutivo das associações, sendo um conjunto de regras abstratas destinado a regular a vida da associação - tanto do ponto de vista referente à organização interna quanto do prisma da relação das entidades com terceiros -, a sua nulidade e ineficácia

${ }^{164}$ MONTEIRO FILHO, Raphael de Barros (et alli). In: TEIXEIRA, Sálvio de Figueiredo (coord). Comentários ao Novo Código Civil. Volume I. Rio de Janeiro: Forense, 2010, p.874

${ }^{165}$ Artigo 54 - Sob pena de nulidade, o estatuto das associações conterá: I - a denominação, os fins e a sede da associação; II - os requisitos para admissão, demissão e exclusão dos associados; III - os direitos e deveres dos associados; IV - as fontes de recursos para a sua manutenção; V - o modo de constituição e de funcionamento dos órgãos deliberativos; VI - as condições para alteração das disposições estatutárias e para a dissolução; VII - a forma de gestão administrativa e de aprovação das respectivas contas. 
implicam a descaracterização da organização como associação e, também, a impossibilidade dessa de se beneficiar das prerrogativas atribuídas às associações por lei.

Os artigos 55 ao 58 descrevem direitos e deveres dos associados, ainda primando pela preservação da unidade da associação como entidade organizada e com finalidades próprias - divergentes daquelas eventualmente colimadas pelos seus associados individualmente. Esses dispositivos são indispensáveis para a conformação do suporte humano da associação e para a transmutação de uma simples organização de pessoas para uma pessoa jurídica apta a manifestar uma vontade una e buscar a realização de seus objetivos institucionais. Os demais artigos regulamentam as atribuições da assembleia geral e a forma de convocação dos órgãos deliberativos, bem como as regras concernentes à dissolução das associações.

Chama atenção, por fim, a última alteração legislativa ocorrida na disciplina das associações: a Lei $\mathrm{n}^{\mathbf{0}} 11.127 / 2005$, que reformou alguns artigos do Código Civil. O legislador focalizou a organização interna das entidades associativas, especificando ainda mais os seus requisitos mínimos de funcionamento, determinando, por exemplo, que se declinassem em estatuto a forma de gestão e de aprovação de contas (artigo 54, VII, do Código Civil) e a necessidade de um procedimento interno norteado pelo princípio da ampla defesa em caso de exclusão de associado (artigo 57 do Código Civil). Ao que parece, procurou-se com essas alterações promover uma moralização interna das entidades associativas, impedindo - na medida do possível - o arbítrio ou a ascendência desmedida de um determinado grupo de associados (e.g. os integrantes da diretoria) sobre os demais.

Pode-se dizer que, hoje, para que uma organização possa ser considerada uma associação, ela deve: (i) ser constituída por meio de um negócio jurídico associativo consubstanciado no estatuto da associação - por duas ou mais pessoas ${ }^{166}$; (ii) possuir órgãos deliberativos e diretivos, que controlarão a administração da entidade, a aprovação das contas, a gestão dos associados (ingresso, permanência e exclusão); e (iii) visar à consecução de um fim comum declinado em estatuto. Se a estes requisitos se somarem a constituição há mais de um ano ${ }^{167}$, a associação será apta para ir a juízo na defesa dos

\footnotetext{
166 O reconhecimento de uma organização como associação civil não depende de registro e, consequentemente, nem de personificação. Nesse sentido, conforme exposto anteriormente, é o entendimento de José Carlos Barbosa Moreira, Kazuo Watanabe, Pontes de Miranda, Erasmo Valladão Azevedo e Novaes França, Sylvio Marcondes e Rodrigo Xavier Leonardo. Sem razão, portanto, Rodolfo de Camargo Mancuso e Raphael de Barros Monteiro Filho.

${ }^{167} \mathrm{O}$ artigo $82, \S 1^{\circ}$, do Código de Defesa do Consumidor, cria uma exceção à regra da pré-constituição, determinando que quando há manifesto interesse social evidenciado pela dimensão ou característica do dano, ou pela relevância do bem jurídico a ser protegido, esse requisito não precisa ser observado. Essa verificação
} 
interesses difusos, coletivos e individuais homogêneos - de seus associados e de toda a sociedade.

A efetiva defesa dos direitos transindividuais - em juízo e fora dele - depende da manutenção de um ambiente propício para o desenvolvimento de associações sérias e qualificadas para fazê-lo. Dessa forma, é necessário analisar o conceito e a natureza jurídica das associações, pela legislação concernente a essas entidades e, ainda, pela capacidade delas de desempenhar adequadamente a defesa dos interesses da coletividade $\mathrm{e}$ atividades circunscritas em seus estatutos.

\subsection{CONCEITO E NATUREZA JURÍDICA}

A natureza jurídica de uma organização - seja ela caracterizada como associação ou sociedade - pode ser discutida sob dois prismas: (i) a natureza jurídica do ato constitutivo; e (ii) a natureza jurídica da própria organização. Importante ressaltar, desde logo, que a questão da natureza jurídica dos atos constitutivos das associações civis não levantou grandes discussões doutrinárias no Brasil até o advento do Código Civil de 2002 e da reforma empreendida especificamente na disciplina das associações pela Lei $\mathrm{n}^{\circ}$ $11.127 / 2005$, uma vez que praticamente inexistia diferenciação entre as associações e as sociedades.

No começo do século XX, a natureza do ato de constituição de sociedades era discutida doutrinariamente, havendo teorias que defendiam ser a constituição um ato complexo e outras que defendiam ser esta um contrato. $\mathrm{O}$ jurista italiano Tullio Ascarelli tratou desse tema em célebre monografia sobre contratos plurilaterais, que muito influenciou a doutrina pátria sobre o assunto ${ }^{168}$.

Tullio Ascarelli defendia que o ato constitutivo das sociedades decorria de um contrato plurilateral celebrado entre os sujeitos de direito criadores da organização. De um ponto de vista formal, os contratos não necessariamente precisam ser instrumentos celebrados entre duas partes, com o objetivo de compor interesses opostos e conflitantes,

ficará a critério do juiz e, como adiante se verá, é uma das formas de verificação da representatividade adequada das associações que foi positivada em nosso ordenamento jurídico. A entrada em vigor desse dispositivo determinou a inclusão do artigo $5^{\circ}, \mathrm{V}$, “b”, §4 $4^{\circ}$, na Lei $\mathrm{n}^{\circ} 4.737 / 1985$, que trata do mesmo assunto.

168 ASCARELli, Tullio. Problemas das sociedades anônimas e direito comparado. São Paulo: Bookseller, 2001, 374. 
mas se prestariam, também, a organizar grupos de pessoas, sob regras diversas daquelas aplicáveis aos contratos bilaterais ${ }^{169}$. De um ponto de vista econômico, Antonio Junqueira de Azevedo define tais contratos como relacionais:

23. Procurando adaptar essas idéias ao nosso mundo conceptual, o que se percebe é que há, no contrato relacional, um contrato de duração e que exige fortemente colaboração. São relacionais todos os contratos que, sendo de duração, têm por objeto colaboração (sociedade, parcerias etc.) e, ainda, os que, mesmo não tendo por objeto a colaboração, exigem-na intensa para poder atingir seus fins, como os de distribuição e da franquia, já referidos. O consórcio, sendo de colaboração e de duração, não resta dúvida, é um contrato relacional. ${ }^{170}$

Com relação às associações, discute-se, ainda, se seu ato constitutivo seria um contrato plurilateral ou negócio jurídico (plurilateral) organizativo. Muito embora a legislação brasileira não diferencie contrato de negócio jurídico, a doutrina brasileira, baseada no Código Civil Italiano ${ }^{171}$ esclarece que o contrato é um negócio jurídico com caráter patrimonial. A esse respeito, Antonio Junqueira de Azevedo explica que "os 'contratos' são somente os acordos bilaterais/plurilaterais de caráter patrimonial e de direito das obrigações" ${ }^{" 172}$. Com base nessa definição de contrato e de negócio jurídico, que se adota neste trabalho devido à reconhecida técnica jurídica dessas definições, Rodrigo Xavier Leonardo entende que a natureza jurídica das associações seria um negócio jurídico organizativo e não um contrato, por faltar justamente o caráter patrimonial:

\footnotetext{
Por todas essas razões, entende-se que a resposta para a natureza jurídica das associações aponta para a verificação de um negócio jurídico organizativo, mediante o qual dois ou mais associados organizam uma entidade capaz de agir autonomamente na busca de fins não-econômicos. Trata-se de instituto, portanto, alheio à disciplina contratual do Código Civil e diretamente ligado à categoria do negócio jurídico, adotada como paradigma normativo para os atos jurídicos lato sensu, pela mesma lei civil ${ }^{173}$.
}

\footnotetext{
169 Assinala Rachel Sztajn sobre os contratos plurilaterais: "Quando as pessoas têm objetivos que, isoladamente, não conseguem atingir, a solução é buscar a cooperação de outras que visem a mesma finalidade, com o que são criados entre elas direitos, deveres e obrigações recíprocos, vínculos esses voltados para a cooperação destinada à consecução de fim comum" (SZTAJN, Rachel. Associações e Sociedades. Revista de Direito Mercantil, Nova série, ano XLI, n.128, São Paulo: Ed. Malheiros, out./dez. 2002, p. 18). 170 JUNQUEIRA DE AZEVEDO, Antonio. Natureza Jurídica do Contrato de Consórcio. São Paulo: RT $\mathrm{n}^{\circ}$ 832, Ano 94, fev. 2005, p. 123.

${ }^{171}$ Código Civil Italiano, em seu artigo 1.321, define contrato como sendo o acordo entre duas ou mais partes para constituir, regular ou extinguir uma relação jurídica patrimonial. No original: "Il contratto è l'accordo di due o più parti per costituire, regolare o estinguere tra loro un rapporto giuridico patrimoniale."

172 JUNQUEIRA DE AZEVEDO, Antonio. Natureza Jurídica do Contrato de Consórcio...Op. cit., p. 121.

${ }^{173}$ LEONARDO, Rodrigo Xavier. A associação em sentido estrito...Op. cit., p.134.
} 
Não obstante, após a constituição da organização, os vínculos jurídicos - tanto aqueles decorrentes do disposto nos estatutos quanto os que se verificam na prática das atividades das associações - se dão entre associados e associação e não entre os integrantes da associação. Os associados não são, em princípio, titulares de pretensão uns contra os outros, mas, somente, em relação à associação. Em outras palavras, a situação do associado se resume à situação jurídica ${ }^{174}$ de pertinência ao grupo ${ }^{175 . .}$

É nesse sentido que se insere a discussão acerca da natureza jurídica da organização - da união de pessoas que se autodenomina como associação - uma vez que ela seria determinada pelo interesse demonstrado pelos integrantes da organização ao se agruparem para constituir um centro de imputação diverso das pessoas individualmente consideradas $^{176}$. No caso das associações, indispensável apurar se o interesse que motivou os associados a se reunirem é eminentemente não econômico. Esse interesse é o que caracteriza uma determinada organização como associação e, em regra, manifesta-se no curso da atuação da entidade e, não necessariamente, está expresso em seus atos constitutivos. Se o interesse for econômico não há associação, mas sociedade.

Tarefa tão árdua quanto definir a natureza jurídica das associações é conceituá-las. Delimitar o conceito de associação stricto sensu (i.e., pessoa jurídica sob a forma de registro como associação civil sem fins lucrativos), é indispensável para a compreensão do tema tratado neste estudo - visto que a análise da representatividade adequada das entidades associativas passará pela verificação dos requisitos preconizados pela legislação

\footnotetext{
${ }^{174}$ A respeito da definição de situação jurídica, Marcos Bernardes de Mello esclarece que: "Há espécies de eficácia jurídica que dizem respeito a uma única esfera jurídica e cujo conteúdo se limita a atribuir a seu titular, apenas, uma qualidade ou uma qualificação no mundo jurídico. Essas espécies as denominamos situações jurídicas simples ou unissubjetivas. O critério metodológico adotado para definir um efeito como situação jurídica simples, ou unissubjetiva, tem por fundamento, tão-somente, a característica de sua referibilidade, direta e imediata, a uma única esfera jurídica, não importando, assim, que à sua base exista direito oponível a todos. Portanto, se a situação jurídica consiste em, apenas, atribuir a alguém qualidade individual ou em lhe conferir qualificação individual, que sirva de suporte fático para normas jurídicas, temse que é simples, ou unissubjetiva, mesmo que haja direito subjetivo à sua imposição, em face de sua oponibilidade a terceiros" (BERNARDES DE MELLO, Marcos. Teoria do fato jurídico: plano da eficácia. 2. ed. São Paulo: Saraiva, 2004, p. 88-89).

Luciano de Camargo Penteado esclarece que a utilidade da técnica de análise a partir da situação jurídica nos casos em que um sujeito de direito ocupa um determinado locus de imputação de interesses, com relação a um determinado objeto (PENTEADO, Luciano de Camargo. Direito das Coisas. São Paulo: RT, 2008, p. 67).

${ }^{175}$ LEONARDO, Rodrigo Xavier. A associação em sentido estrito...Op. cit, p.129.

${ }^{176}$ A respeito da caracterização de sociedades por ações a partir do interesse, ver "Die Natur der Aktiengesellschaft - Anmerkungen zum Bedeutungswandel einer aktienrechtlichen Schlüsserkategorie". KLAGES, Philipp. In: REHBERG, Karl-Siegbert (coord.). Verhandlungsband des 33. DGS-Kongresses Kassel (CD-Rom), disponível em http://www.ssoar.info/ssoar/files/dgs/33-2006/5729.pdf. Acessado em 13 mar.2011.
} 
para atribuir a elas legitimidade para a propositura de ações coletivas. E um desses requisitos é, justamente, ser a entidade uma associação constituída nos termos da lei civil.

A Constituição Federal de 1988 trata de associações de forma ampla, abrangendo demais tipos de organizações personalizadas ou não, como, por exemplo, as sociedades. A esse respeito, Rodrigo Xavier Leonardo esclarece que a disciplina constitucional “[...] serve de suporte para toda e qualquer organização de pessoas dotada de razoável estabilidade e destinada ao desenvolvimento de uma atividade comum"177. Essa generalidade garante a abrangência de diversas situações jurídicas e fenômenos associativos - impedindo que sejam coibidos pelo simples fato de não se enquadrarem em um conceito fechado de associação, que é, posteriormente, especificado pela legislação infraconstitucional. Além disso, por outro lado, torna árdua a tarefa de reunir os elementos comuns de todas essas entidades e classificá-las de acordo com essa realidade plural ${ }^{178}$.

Assim, sendo grande a chance de se tornar improdutiva qualquer tentativa de fixar um conceito estrito de associação, propõe-se a adoção da metodologia do pensamento tipológico para uma apreensão de uma realidade plural sem abstrair aquilo que é incomum na diversidade de objetos analisada ${ }^{179}$. A utilização dessa metodologia - em contraposição ao pensamento por conceitos abstratos ${ }^{180}$ - pressupõe, segundo Karl Larenz, a adoção de um determinado número de pontos característicos, por meio dos quais seja possível delinear em que medida uma realidade pode ser considerada típica, podendo se tomar como ponto de partida aquela caracterização abstrata de associação indicada na Constituição Federal e, também, na legislação infraconstitucional ${ }^{181}$. A ideia, portanto, é

\footnotetext{
${ }^{177}$ LEONARDO, Rodrigo Xavier. A associação em sentido estrito...Op. cit, p.89.

${ }^{178}$ Citem-se, como exemplos, algumas definições de associações encontradas na doutrina: "No sentido do texto brasileiro, associação é toda coligação voluntária de algumas ou muitas pessoas físicas, por tempo longo, com o intuito de alcançar algum fim (lícito), sob direção unificante" (PONTES DE MIRANDA. Comentários à constituição de 1967 com a ementa n. I de 1969. 2.ed. São Paulo: RT, 1971, p. 608); “[...] entidades privadas sem fins lucrativos, dedicadas à defesa de direitos e interesses que, no caso, transcendem a esfera individual de seus membros e associados. [...] criadas espontaneamente no seio da sociedade [...]." (Ver "Associações civis e a defesa dos interesses difusos em juízo: do direito vigente ao direito projetado". MIRRA, Luiz Álvaro Valery. In: GRINOVER, Ada Pellegrini (coord.). Direito Processual Coletivo e anteprojeto de Código Brasileiro de Processos Coletivos. São Paulo: ed. RT, 2007, p. 114-135); "Associação é a reunião de várias pessoas para a realização de objetivos ideais sem fins de lucro, dotada de personalidade jurídica” (CUSTÓDIO, Helita Barreira. Associações e fundações de utilidade pública. São Paulo: RT, 1979, p. 40).

${ }^{179}$ LEONARDO, Rodrigo Xavier. A associação em sentido estrito...Op. cit, p. 92.

${ }^{180}$ A antiga orientação da jurisprudência dos conceitos (Begriffsjurisprudenz) é evidentemente inadequada por limitar a atividade jurisdicional à subsunção lógica de fatos a conceitos jurídicos fechados. A respeito ver LARENZ, Karl. Metodologia da ciência do direito. 3. ed. Traduzido por José Lamego. Lisboa: Calouste Gulbekian, 1997, p. 63-77).

181 “[...] a seleção dos fenômenos decisivos e a delimitação mais concreta do tipo são determinadas juntamente pelo escopo da norma e pelas idéias jurídicas que estão por detrás da regulação. [...] a apreensão
} 
tentar reunir sob um determinado tipo as características que, com maior fidelidade, expressem o que se entende por associação no atual panorama legal e social do Brasil ${ }^{182}$.

Partindo do tipo associativo geral, delimitado pela Constituição Federal que cuida da liberdade de associação, podem-se destacar dois grandes subtipos que serão cuidadosamente diferenciados no próximo capítulo: as associações em sentido estrito e as sociedades. Interessam, nesse momento, as associações em sentido estrito, cujos traços característicos estão delineados, basicamente, pelo artigo 53 do Código Civil, que preconiza serem associações em sentido estrito a “[...] união de pessoas que se organizem para fins não econômicos". São, portanto, três características básicas: (i) a união de pessoas; (ii) organização; (iii) desenvolvimento de fins não econômicos (entre outros, a vedação da distribuição de lucros) ${ }^{183}$.

Sendo assim, é pertinente analisar com maior atenção cada uma dessas características que, juntas, conformarão o conceito de associação civil, ao qual este estudo pretende chegar.

\subsubsection{União de pessoas}

Esse requisito identifica o suporte humano, devendo a associação ser formada por um determinado número de pessoas reunidas - em caráter perene ou duradouro ${ }^{184}$ - com um objetivo comum.

de um tipo jurídico-estrutural tem o seu ponto de partida no conjunto da regulamentação que este tipo teve, seja na lei, seja já, no caso de se tratar de um tipo contratual extralegal, no respectivo contrato. A caracterização antecipada na lei, que não impõe uma definição definitiva e suficientemente precisa, necessita de ser complementada com uma multiplicidade de traços, que resultam por dedução da definição legal. Esta 'dedução' está subordinada ao pressuposto de que as regras legais se adéquam ao tipo pensado, que se 'ajustam' a ele (LARENZ, Karl. Metodologia da ciência do direito...Op. cit., p. 658-665). A utilidade dessa definição tipológica para o presente estudo é, justamente, a possibilidade de extrapolar o texto expresso da lei para, ao determinar o tipo da associação, atingir um espectro mais amplo, que abranja desde a correspondência entre os estatutos das entidades à lei até sua efetiva atuação - como "partes do todo" que seria o tipo associativo.

${ }^{182}$ A adoção do pensamento tipológico tem como vocação a aproximação da realidade, em contraposição ao pensamento conceitual que, naturalmente, dela se distancia para criar caracteres genéricos. Ainda assim, a redução de um conceito como tipo também tem uma carga de abstração, por se colocar de forma abstrata em relação ao caso particular - nas palavras de Oliveira Ascenção "[...] o tipo ocupa uma posição intermediária entre o conceito de referência e o caso individual” (ASCENÇÃO, José de Oliveira. A tipicidade dos direitos reais. Lisboa: Livraria Petroni, 1968, p.36).

${ }^{183}$ LEONARDO, Rodrigo Xavier. A associação em sentido estrito...Op. cit, p. 96.

${ }^{184}$ Há que fazer diferenciação entre as associações e as reuniões em caráter precário e transitório. Os dois direitos são garantidos constitucionalmente (artigo $5^{\circ}$, VXI), mas a associação pressupõe o estabelecimento de um vínculo mais intenso do que a mera reunião. Assinala, nesse sentido, Pontes de Miranda: "Na liberdade de associação há mais do que reunião; e o reunir, que lhe é implícito, toma caráter geral, físico e 
Não há na legislação brasileira nenhuma exigência de número mínimo ou máximo de associados necessários para que determinada pessoa jurídica possa ser caracterizada como associação - embora alguns ordenamentos estrangeiros, a exemplo do espanhol, tenham positivado a necessidade de um número mínimo de pessoas para a constituição de uma associação ${ }^{185}$. Pressupõe-se, no entanto, que a associação - com ou sem personalidade jurídica diversa daquela de seus associados - deva contar com pelo menos dois associados, uma vez que o próprio termo "união", enquanto característica do tipo associativo, determina a existência de mais de uma pessoa ${ }^{186}$.

A ideia de união de caráter perene ou duradouro - além de permitir uma diferenciação entre o direito de associação e o direito de reunião - traduz-se no conceito de substrato corporativo. Para Pontes de Miranda, a união de indivíduos visando à constituição de uma associação deve ser qualificada por uma intenção corporativa - de constituir uma entidade de existência independente dos associados ${ }^{187}$ e 188 .

A terminologia "união de pessoas" é bastante esclarecedora quanto ao conteúdo da expressão. Traçadas as bases que definem a ideia de "união", cabe discutir o que se entende por "pessoas", questionando se seria possível uma associação que resultasse da agregação de outras pessoas jurídicas ou se tal tipo associativo estaria restrito à união de pessoas naturais.

psíquico" (PONTES DE MIRANDA. Democracia, liberdade e igualdade (os três caminhos), São Paulo: José Olympio, 1945, p. 419).

${ }^{185} \mathrm{O}$ artigo $5^{\circ}$ da Lei Orgânica 1/2002 da Espanha exige para a constituição de uma associação a união de, pelo menos, três pessoas. A doutrina portuguesa também faz considerações sobre o assunto, pontuando que a independência funcional dos órgãos da associação - e a necessidade desses órgãos se fiscalizarem reciprocamente - pressuporia a existência de, pelo menos, seis associados (LEONARDO, Rodrigo Xavier. A associação em sentido estrito...Op. cit., p. 102).

${ }^{186}$ Nesse sentido, Herbert Wiedemann esclarece que uma associação requer, no mínimo, a participação de duas pessoas, sendo que a lei pode até estabelecer um número mínimo maior para garantir estabilidade à associação: "Eine Personenvereinigung setzt die Beteiligung von mindestens zwei Personen voraus; nach oben ist die Mitgliederzahl begrifflich nicht begrenzt. Das positive Recht kann die Mindestbeteiligung erhöhen, um dem Verband eine gewisse Beständigkeit zu garantieren [...]" (Tradução livre: Uma união de pessoas requer a participação de, no mínimo, duas pessoas; não há um limite máximo de participantes. A lei pode aumentar o número mínimo de participantes, com o objetivo de garantir um mínimo de estabilidade para a entidade) - (WIEDMANN, Herbert. Gesellschaftsrecht. Band I, München: C. H. Beck, 1980, p. 4-5).

${ }^{187}$ PONTES DE MIRANDA, Francisco Cavalcante. Tratado de Direito Privado. 3. ed. tomo I. Rio de Janeiro: Borsoi, 1970, p. 321. Nesse sentido, ver também FERRARA, Francesco. Teoria delle persone giuridiche. 2. ed. Napoli/Torino: Eugenio Marguieri/Unione Tip Editrice Torino, 1923, p.35.

${ }^{188}$ Como assevera Lamartine Correa: "Tais entidades são - em um plano pré-normativo - pela identidade e continuidade que os homens lhe reconhecem, através do tempo, fazendo com que a entidade seja a mesma apesar da mudança de seus membros; pela formação de um centro autônomo de interesses; pela dotação de órgãos capazes de deliberar de modo vinculante, permitindo que declarações de vontade emanem de tais entidades - seres" (CORREA DE OLIVEIRA, J. Lamartine. A dupla crise da Pessoa Jurídica. São Paulo: Saraiva, 1979, p. 606). 
Conquanto exista divergência na doutrina, com nomes de expressiva notoriedade defendendo que a liberdade de associação se restringe às pessoas físicas ${ }^{189}$, não há na legislação nenhuma limitação que vete a participação de pessoas jurídicas na formação de associações. De fato, são diversos os exemplos de associações civis formadas por pessoas jurídicas em nosso país ${ }^{190}$, de modo que restringir a liberdade associativa somente às pessoas naturais acabaria por excluir uma série de manifestações legítimas e funcionais ${ }^{191}$.

Definidas as características do que se entende por suporte humano das associações, cabe entender de que forma os integrantes se organizam internamente para, dentro dos limites estabelecidos pela lei, garantir a consecução dos objetivos institucionais traçados em estatuto e que, em tese, fomentaram a constituição da associação e definiram seu âmbito de atuação.

\subsubsection{Organização}

O conceito de substrato corporativo, que deve estar presente para que a análise tipológica das associações esteja completa, preconiza que o vínculo entre os associados se transfigure em um todo único e maior que a simples soma dos integrantes individuais. Essa ideia, de alguma forma, coaduna-se com o segundo elemento caracterizador do tipo associativo - a organização dos associados ${ }^{192}$. Isso porque a organização juntamente com a intenção de união prolongada no tempo são exatamente aquilo que diferencia o "todo" dos "componentes isolados" - contando o primeiro com características ausentes no segundo.

O Código Civil de 2002 - notadamente a partir da Lei $n^{\circ}$ 11.127/2005 - determinou que o estatuto social regulasse detalhadamente a organização interna das associações, desde a previsão expressa da necessidade de órgãos deliberativos e administrativos da entidade até a composição e competência de tais órgãos e o papel deles na constituição, no desenvolvimento das atividades e mesmo na dissolução das associações. Dessa forma, o

\footnotetext{
189 Pontes de Miranda defendia essa restrição, por considerar tratar-se o direito de associação de um desdobramento direto da Declaração dos Direitos do Homem: "A liberdade de associação, como a de reunião, é direito da pessoa física. Não pode invocar a liberdade de associação, direito do homem, qualquer pessoa jurídica [...] nem a que deseje aderir ao negócio jurídico de associação" (PONTES DE MIRANDA. Comentários à Constituição de 1967 com a emenda n. I, de 1969. 2. ed. São Paulo: RT, 1971, p. 605-608). 190 Citem-se, como exemplos, a Associação Brasileira dos Fabricantes de Brinquedos (ABRINQ), cujo estatuto prevê a possibilidade de pessoas físicas e jurídicas fabricantes de brinquedos serem associados, a Federação Brasileira de Bancos (FEBRABAN), que congrega instituições financeiras de todo o território nacional e a Associação Brasileira das Entidades dos Mercados Financeiro e de Capitais (ANBIMA).

${ }^{191}$ LEONARDO, Rodrigo Xavier. As associações em sentido estrito...Op. cit., p. 98.

${ }^{192}$ Ibid., p. 100-101.
} 
estatuto social tem como função não apenas regular a relação da pessoa jurídica com terceiros, mas também disciplinar as relações internas - entre os associados - por meio da dinâmica estabelecida pelos órgãos internos do ente social.

Assim, seguindo esse raciocínio, uma associação cujo estatuto não preveja de forma adequada o modo de constituição e o funcionamento dos órgãos deliberativos (artigo 54, V, do Código Civil ${ }^{193}$ ), a forma de inclusão e exclusão de sócios (artigo 57 do Código Civil $^{194}$ ), bem como a competência da assembleia geral (artigo 59, I e II, do Código Civil $^{195}$ ), não pode ser considerada como uma entidade devidamente constituída nos termos da lei - o que tem diversas implicações do ponto de vista prático, inclusive com relação à atribuição de legitimidade às associações para a propositura de ações coletivas (vide capítulos 4 e 5).

As regras propostas pelo Código Civil de 2002 não têm o condão de interferir na liberdade associativa, mas, apenas, prestam-se a criar um arcabouço mínimo de estruturação, que reúna sobre um mesmo conjunto de regras as características de organização que devem ser comuns a todas as associações stricto sensu.

Tanto a característica da união de pessoas como a da organização dessas pessoas no seio da entidade associativa são interpretadas do ponto de vista da diferenciação entre o grupo de pessoas físicas ou jurídicas (considerados como elementos isolados) e o ente associativo (como nova figura, dotada de características próprias). Enquanto a união entre os associados delimita as fronteiras do grupo em relação aos demais integrantes da sociedade civil, a estruturação interna em órgãos serve para viabilizar as relações jurídicas entre os componentes do grupo e dessa coletividade organizada com terceiros. Ambas as características, portanto, situam-se no âmbito da constituição da associação - em um momento anterior ao início do desenvolvimento de suas atividades.

A característica remanescente do tipo associativo, entretanto, evolui para a discussão dos fins institucionais eleitos pelas associações, bem como para a forma como eles são desenvolvidos na prática - verificando se estes se alinham com os ditames estabelecidos pela lei, especialmente no que concerne à ausência de fins econômicos das atividades praticadas pelas entidades associativas.

\footnotetext{
193 Artigo 54. Sob pena de nulidade o estatuto das associações conterá: V - o modo de constituição e de funcionamento dos órgãos deliberativos.

194 Artigo 57. A exclusão do associado só é admissível havendo justa causa, assim reconhecida em procedimento que assegure direito de defesa e de recurso, nos termos previstos no estatuto.

195 Artigo 59. Compete privativamente à assembléia geral: I - destituir os administradores; II - alterar o estatuto.
} 


\subsubsection{Desenvolvimento de finalidades não econômicas}

Para ser considerada uma associação civil, a pessoa jurídica deverá, além dos requisitos supracitados, realizar atividades que não sejam voltadas a atingir uma finalidade econômica. A terminologia empregada no artigo 53 do Código Civil fala no desenvolvimento de "fins não econômicos". Entende-se por "fim" o escopo, o objetivo da associação, e não o seu objeto - ou seja, não se exige que os estatutos designem, de antemão, quais as atividades específicas que serão desenvolvidas pela entidade ou de que forma cada um dos associados contribuirá para a realização desse objeto ${ }^{196}$.

Assim, é lícito interpretar que uma associação deva, em seu estatuto, declarar que pretende, por exemplo, "atuar na defesa dos direitos do consumidor"197 - expressão que descreve sua finalidade institucional -, mas não há que se exigir uma completa descrição dos atos que serão praticados para que essa finalidade seja atingida.

Pertinente, por esse motivo, delimitar, da maneira mais precisa possível, o que seria o desenvolvimento de uma atividade econômica, voltada unicamente à obtenção de lucro, cujo exercício é vetado às associações civis. A separação entre sociedades que buscam o lucro e entidades associativas destituídas de escopo lucrativo marca presença nos mais diversos ordenamentos jurídicos, entre eles o brasileiro, sendo que a discussão mais profunda situa-se na zona limítrofe entre os dois conceitos: como diferenciar a atividade que se presta a obter receitas destinadas à manutenção da própria associação daquelas que possam ser caracterizadas como "desenvolvimento de finalidades econômicas"?

A nota que diferencia essas duas situações está no fato de que o legislador, a despeito de ter vetado associações que tenham por finalidade o desenvolvimento de atividades econômicas, não pretendeu extirpar o lucro das entidades associativas, mas sim sua distribuição entre os associados e diretores. A finalidade econômica tem espectro mais amplo do que a simples lucratividade - traduz-se na ideia de que todas as atividades de determinada entidade se destinam à geração de riqueza e a consecução de interesses econômicos ${ }^{198}$. As associações civis não podem, portanto, direcionar suas atividades para a

\footnotetext{
${ }^{196}$ LEONARDO, Rodrigo Xavier. As associações em sentido estrito...Op. cit., p. 105-106.

${ }^{197}$ A descrição das finalidades da associação no estatuto é indispensável, aliás, para que se verifique se o ente constituído é realmente uma associação e ainda para se aferir a legitimidade da entidade para a propositura de ações civis públicas, conforme será discutido detalhadamente no capítulo seguinte.

${ }^{198}$ As atividades características das sociedades, em que se perquirem ganhos para posterior divisão entre os sócios, não são o único exemplo de atividade voltada à consecução de fins econômicos. Também nas sociedades cooperativas há o intuito direto de auferição de benefícios econômicos - por exemplo aumentando o poder de barganha dos seus integrantes no mercado, auferindo vantagens advindas da redução do preço
} 
geração de riquezas, com o objetivo de eventualmente repartir os resultados entre os associados, mas nada impede que desenvolvam atividades geradoras de receitas, permitindo a autossustentação da entidade ${ }^{199}$.

A linha divisória é tênue, mas deve ser observada com vagar e atenção no decorrer das atividades desenvolvidas pelas associações e em sua disciplina normativa. O Código Civil ressalta em seu artigo 54, inciso IV, a necessidade de constar no estatuto das associações as fontes de recursos para a manutenção da entidade - fontes essas que são indispensáveis para a realização dos fins não econômicos e para reverter em benefícios aos associados. Parte da doutrina acredita que essas fontes de receitas somente podem ser limitadas à contribuição dos associados. Entretanto, desde que a obtenção de valores se reverta para a consecução dos fins institucionais - esses sim destituídos de caráter econômico - essa fonte não pode ser considerada como algo que descaracteriza a associação civil.

A ausência de fins econômicos pode ser considerada, portanto, como o mais polêmico dos elementos caracterizadores das associações civis - sendo que a apuração entre o que se pode considerar um fim econômico e o que pode ser tido como mera atividade lucrativa (que se presta ao sustento da própria entidade), deverá se dar na prática e após o início das atividades da associação. Vale dizer que o escopo econômico, com

para aquisição de bens -, muito embora nestas, em geral, não esteja presente o escopo lucrativo (SZTAJN, Rachel. Associações e Sociedades...Op. cit., p. 21). Até por esse motivo, diversas foram as divergências na doutrina brasileira e estrangeira acerca da natureza jurídica das cooperativas - se seriam associações ou sociedades. Na Itália a questão foi resolvida após problemas práticos, em que se debateram a possibilidade de conversão de uma cooperativa em uma sociedade anônima, tendo sido decidido que tal conversão seria possível. Para o autor italiano Ernesto Simonetto, essa identidade entre a cooperativa e a sociedade parte do pensamento tipológico, havendo maior afinidade de características entre as cooperativas e as sociedades do que entre aquelas e as associações - muito embora existam diferenças marcantes (SIMONETTO, Ernesto. Società e mutualità. Rivista di diritto civile, Padova, ano X, n. 4, Lug/Ago, 1964, p. 406). No Brasil, a cooperativa é classificada como sociedade pelo próprio Código Civil de 2002, em que consta capítulo específico “das Sociedades Cooperativas” (Livro II, Título II, Subtítulo II, Capítulo VII do Código Civil).

${ }^{199}$ LEONARDO, Rodrigo Xavier. As associações em sentido estrito...Op. cit., p. 107-108. Nesse sentido, ver também o magistério de Masimo Bianca: "Il problema non è se l'attivitá commerciale posta in essere da un'associazione sia lecita, ma è piuttosto se l'esercizio di un'attività commerciale in via esclusiva o principale sia compatibile con la natura di ente morale dell'associazione. La risposta negativa discende dal rilievo che l'attività commerciale è essa stessa un'attività di profitto. Il fatto che la destinazione degli utiliti abbia uno scopo ulteriore non toglie che questi ultimi vengano conseguiti prima di essere poi utilizzati secondo la volontà dei soci. Per escludere il carattere commerciale occorrerebbe che l'attività esercitata fosse insuscettibilie di profitto, limitandosi ad una erogazione di beni o servizi con semplice rimborso dei costi" (tradução livre: O problema não é se a atividade comercial exercida por uma associação é legítima, mas sim se o exercício de uma atividade comercial em si é compatível com a natureza de uma associação de caridade. Da resposta negativa decorre que o negócio é uma atividade com fins lucrativos. Para excluir o propósito comercial deve o trabalho realizado ser inelegível para o lucro, apenas uma entrega de bens ou serviços com simples reembolso dos custos). (BIANCA, Cesare Massimo. Diritto Civile. Vol. I. 2. ed. Milano: Giuffrè, 2002, p. 366). 
distribuição de lucros aos associados, pode culminar na descaracterização da associação, seu enquadramento como sociedade irregular e em eventual dissolução.

Por esse motivo, importa discorrer sobre as principais diferenças que se observam entre as associações e outras pessoas jurídicas, buscando estabelecer um limite entre suas atividades, justamente para que seja possível identificar situações em que pode ocorrer abuso da forma associativa e, com isso, também, o abuso de direito, que acabará desbordando para o âmbito processual pela via da legitimidade ativa concedida às associações para a propositura de ações coletivas.

\subsection{PRINCIPAIS DIFERENÇAS ENTRE AS ASSOCIAÇÕES CIVIS E AS DEMAIS PESSOAS JURÍDICAS DE DIREITO PRIVADO}

O Código Civil lista, no artigo 44, quais são as pessoas jurídicas de direito privado, a saber: (i) as associações; (ii) as sociedades; (iii) as fundações; (iv) as organizações religiosas; e (v) os partidos políticos. Cada uma dessas pessoas jurídicas tem características próprias e regulamentação específica ${ }^{200}$.

Como já destacado anteriormente, as associações e sua atuação em juízo serão o objeto desse estudo e como a legitimidade para a atuação em defesa dos interesses difusos, coletivos e individuais homogêneos pressupõe o reconhecimento da entidade como associação, caberá discorrer brevemente sobre as diferenças entre a associação e as demais pessoas jurídicas de direito privado - em especial as sociedade e fundações - destacando quais características devem ser observadas para que se possa atribuir, com algum grau de técnica jurídica, a legitimidade ativa e outras benesses concedidas pela lei a uma determinada pessoa jurídica.

A primeira divisão que se pode fazer entre as pessoas jurídicas de direito privado é: separar de um lado as corporações (universitas personarum) - grupos de pessoas reunidas por uma causa comum -, entre as quais estão as sociedades e as associações; e, de outro lado, alocar aquelas em que a organização, para a consecução de um determinado fim, é montada a partir de um patrimônio (universitas bonorum), que é o caso das fundações.

\footnotetext{
200 As associações, sociedades e fundações são disciplinadas, primordialmente, pelo Código Civil. As organizações religiosas, que eram tratadas sob o mesmo regime das associações, passaram a ter disciplina própria pela Lei 10.825 , de 22 de dezembro de 2003. Os partidos políticos são regulados como figuras autônomas desde 1995 pela Lei 9.096.
} 
As fundações são um patrimônio destinado a uma finalidade específica, determinada pelo instituidor, cuja personalidade jurídica é atribuída pela lei ${ }^{201}$ e cuja criação decorre de ato ou negócio jurídico unilateral (negócio jurídico fundacional) ${ }^{202}$.

A diferença entre fundações e associações, portanto, é clara e apreensível: enquanto as fundações são organizadas a partir da destinação de um patrimônio para determinado fim, a partir da vontade unilateralmente manifestada pelo fundador, as associações são formadas a partir de um conglomerado de pessoas que manifestam sua vontade de se reunir para a consecução de uma finalidade comum. Mais difícil é diferenciar as entidades que contam com substrato corporativo - associações e sociedades - o que se buscará fazer nas linhas seguintes.

As diferenças entre sociedades e associações são relevantes, especialmente em vista da multiplicação dessas organizações. A esse respeito, Rachel Sztajn destaca que:

[...] a recente multiplicação de organizações sociais que servem como instrumento que, a par de reunir pessoas com interesse comum e que podem funcionar como instrumentos de pressão na defesa desses interesses específicos, torna a análise do fenômeno relevante. Se a razão da constituição dessas organizações é, do ponto de vista da sociologia, encarada como forma de mediar as relações entre pessoas, entre indivíduos e Estado, o ordenamento jurídico deve dar-lhes disciplina adequada. ${ }^{203}$

Para além da investigação legislativa sobre o tema, é importante ressaltar o motivo pelo qual se empreende essa diferenciação no contexto deste estudo. O que se pretende é evitar que pessoas jurídicas de direito privado, que se denominam associações e, até mesmo, tem forma associativa, ajam como sociedades - notadamente quanto à persecução de vantagens econômicas e distribuição delas entre seus integrantes -, valendo-se, em detrimento dos seus associados e, em alguns casos, de toda a sociedade, das benesses legais, concedidas às associações para a defesa em juízo dos interesses transindividuais. Delimitar de forma precisa as características das associações e das sociedades em sua forma e, principalmente, em sua atuação, é indispensável para reconhecer e evitar essas situações anômalas, abusivas e contrárias à boa-fé.

\footnotetext{
${ }^{201}$ DINIZ, Gustavo Saad. Direito das fundaçoes privadas. Revista Jurídica: Brasília Jurídica, Brasília, n²51, 2008, p. 25. O artigo 62 do Código Civil, que cria as bases do conceito de fundação, dispõe que a criação da fundação se dará por escritura pública ou testamento, dotação especial de bens livres, sendo que seu instituidor deverá especificar a que fim esse patrimônio se destinará e declarará, se quiser, a maneira de administrar a entidade.

${ }^{202}$ PONTES DE MIRANDA. Tratado de Direito Privado. tomo 1. 3. ed. Rio de Janeiro: Ed. Borsoi, 1970, p.454.

${ }^{203}$ SZTAJN, Rachel. Associações e Sociedades...Op. Cit., p. 16.
} 
A principal diferença entre as associações e as sociedades está no fato de que a primeira não pode perseguir finalidades econômicas, enquanto a segunda tem por característica específica justamente a persecução dessas finalidades ${ }^{204}$. Diz-se principal porque tanto a doutrina nacional quanto a estrangeira, apontaram algumas outras notas que diferenciam as duas pessoas jurídicas de direito privado, por exemplo: Francesco Ferrara assinala que nas associações há variabilidade de membros e na sociedade ${ }^{205}$ não - o que não se verifica, uma vez que os membros das sociedades também podem ser alterados mediante a verificação da affectio societatis -; Tulio Ascarelli pontua que na associação há o gozo imediato das utilidades, enquanto na sociedade esse gozo se daria por meio da distribuição de dividendos ${ }^{206}$; Orlando Gomes entende que na associação o fím perseguido é ideal, ao passo que nas sociedades a finalidade colimada é o benefício comum dos sócios e, apenas nessas últimas, há direitos e obrigações recíprocas entre os integrantes ${ }^{207}$.

Conforme descrito anteriormente, a discussão acerca das diferenças entre sociedades e associações prevaleceu na doutrina até a entrada em vigor do Código Civil de 2002, porquanto não existisse uma disciplina específica para cada uma das pessoas jurídicas de direito privado e também pelo fato dos termos "associação" e "sociedade" serem usados como sinônimos - muito embora se falasse em "associações de fins não econômicos" (artigo 22) e em "sociedade de fins econômicos” (artigo 23) no Código Civil de 1916.

Na legislação estrangeira essa imprecisão terminológica não se observava. No Código Civil Alemão (Bürgerliches Gesetzbuch - BGB), por exemplo, os agrupamentos de pessoas foram classificados como organizações com fins econômicos (Wirtschaftlicher Verein, $§ 22$ do BGB $^{208}$ ) e organizações sem fins econômicos (Nichtwirtschaftlicher

\footnotetext{
204 Aponta Rachel Sztajn que "o que é assente na doutrina e, agora, na legislação, é que sociedades e associações têm, na finalidade econômica daquelas, inexistentes nestas, seu traço diferenciador, mesmo que pudesse haver, na vigência do Código Civil de 1916, discordâncias quanto a tal divisão" (SZTAJN, Rachel. Associações e Sociedades...Op. cit., p. 17. Nesse sentido, ver também Pontes de Miranda, que assinala o mesmo ponto de vista, mas, com outras palavras "a associação teria fim altruístico, ao passo que a sociedade o teria egoístico" (PONTES DE MIRANDA. Tratado de Direito Privado. tomo XLIX. Rio de Janeiro: Ed. Borsoi, 1965, p. 27).

${ }^{205}$ FERRARA, Francesco. Teoria delle persone giuridice. 2.ed. Napoli/Torino: Eugenio Marguieri/Unione Tip Editrice Torino, 1923, p. 497.

${ }^{206}$ ASCARELLI, Tulio. Societá, associazioni, consorzi, cooperative e transformazione. Revista Del Diritto Commercialle, Milano, n. II, 1949, p. 425.

${ }^{207}$ GOMES, Orlando. Introdução ao Direito Civil. 13.ed. Rio de Janeiro: Forense, 1996, p. 185-187.

${ }^{208} \S 22$ BGB. Ein Verein, dessen Zweck nicht auf einen wirtschaftlichen Geschäftsbetrieb gerichtet ist, erlangt Rechtsfähigkeit durch Eintragung in das Vereinsregister des zuständigen Amtsgerichts (Tradução livre: Uma organização, cujo objetivo não é a realização de negócios com funções econômicas, obtém personalidade jurídica através do registro de seus estatutos no tribunal local competente).
} 
Verein, $\S 21$ do $\mathrm{BGB}^{209}$ ), desde o princípio definindo que o critério diferenciador das duas entidades era o seu escopo econômico. Na doutrina alemã, embora se anotem algumas divergências, a posição majoritária é no sentido de que a apuração desse objetivo se dá na prática, por meio da observação do comportamento dos associados, avaliando se este está voltado à persecução de vantagens econômicas ${ }^{210}$.

A mesma orientação foi observada nos ordenamentos jurídicos e pela doutrina da Itália $^{211}$ e de Portugal $^{212}$, em que também se asseverou que a principal diferença entre as associações e as sociedades são os objetivos altruístas e não econômicos das primeiras, em comparação aos fins eminentemente egoísticos e lucrativos das segundas.

O Código Civil de 2002 explicitou a principal diferença entre as associações e sociedades no texto dos artigos 53 - "constituem-se as associações pela união de pessoas

${ }^{209} \S 21$ BGB. Ein Verein, dessen Zweck auf einen wirtschaftlichen Geschäftsbetrieb gerichtet ist, erlangt in
Ermangelung besonderer bundesgesetzlicher Vorschriften Rechtsfähigkeit durch staatliche Verleihung. Die
Verleihung steht dem Land zu, in dessen Gebiet der Verein seinen Sitz hat. (Tradução livre: Uma
organização, cujo objetivo é a realização de negócios com funções econômicas, adquire personalidade
jurídica, na falta de disposições específicas em lei federal, através de cerimônia oficial. Tal cerimônia
ocorrerá no local em que a organização estiver sediada).
${ }^{210}$ Em obra conjunta, Karl Larenz e Manfred Wolf asseveram que: "Die Abgrenzung der beiden Vereinsarten
nicht wirtschaftlicher Idealverein und wirtschaftlicher Verein richtet sich gemäß \$§ 21 , 22 danach, ob "der
Zweck des Vereins auf einen wirtschaftlichen Geschäftsbetrieb gerichtet ist" oder nicht. Diese Formulierung
läßt mehrere Deutungen zu [...].Die neuere Lehre versuch demgegenüber zu Recht, den objektiven
Gegebenheiten mehr Gewicht beizumessen. So reicht es insbesondere nicht, daß die Vereinsmitglieder
wirtschafliche Gewinne anstreben. Vielmehr ist entscheidend, ob ein wirtschaftlicher Geschäftsbetrieb
vorliegt, der Verein also eine unternehmerische Tätigkeit tatsächlich ausübt. Umstritten ist, ob es sich um
einen eigenen Geschäftsbetrieb des Vereins handeln muß oder ob es sich auch um einen Geschäftsbetrieb
außerhalb des Vereins selbst handeln kann." (tradução livre: A diferença entre os dois tipos de associação,
associação sem fins econômicos e associação com fins econômicos, está nos artigos 21 , 22. Esses artigos
estabelecem que "o objetivo da associação é dirigida a uma atividade comercial” ou não. Esta formulação
permite múltiplas interpretações. A teoria mais recente vai de encontro à lei para tentar dar mais peso às
realidades objetivas. Não é suficiente que os integrantes da associação se abstenham de buscar o lucro. Pelo
contrário, depende da verificação de existência de uma operação de negócio comercial, em que a associação
esteja realmente engajada. É discutível se a atividade lucrativa deve ser praticada pela própria associação ou
se também pode ser um negócio fora da associação em si.), ver: LARENZ, Karl; WOLF, Manfred. Allgemeiner Teil des Bürgerlichen Rechts. 9.ed. München: C.H. Beck, 2004, p. 178-179.

211 "L'associazione ha spesso uno scopo ideale o altruistico ma può anche soddisfare un interesse economico dei suoi membri. L'interesse economico deve tuttavia essere realizzato esclusivamente attraverso una utilità percepita dall'associato nella sua attività individuale. Se, invece, l'attività comune tende a realizzare un profitto e a dividerlo tra i compartecipi, il gruppo si identifica nello schema della società." (tradução livre: A associação tem um propósito ideal ou altruísta, mas também pode atender a interesse econômico de seus membros. O interesse econômico, no entanto, só pode ser alcançado por uma utilidade percebida pelo associado em sua atividade individual. Se, em vez disso, a atividade comum tende a buscar o lucro e dividi-lo entre os participantes, o grupo é identificado no diagrama da sociedade.), ver: BIANCA, Cesare Massimo. Diritto Civile. Vol. I. 2.ed. Milano: Giuffrè, 2002, p. 364-365.

212 "Há antes de mais que demarcar o âmbito da categoria. O art. 157 manda aplicar as disposições do capítulo sobre pessoas coletivas às associações que não tenham por fim o lucro econômico dos associados. A disposição parece deixar subentendido que também há associações que têm por fim o lucro (econômico) dos associados, embora se lhe não apliquem aquelas disposições. Porém, uma associação dirigida ao lucro é uma sociedade, que o art. 157 igualmente refere" (ASCENSÃO, José de Oliveira. Direito Civil: Teoria Geral. vol 1. 3. ed. São Paulo: Saraiva, 2010, p. 236). 
que se organizem para fins não econômicos" - e do artigo 981 - "celebram contrato de sociedade as pessoas que reciprocamente se obrigam a contribuir, com bens ou serviços, para o exercício de atividade econômica e a partilha, entre si, dos resultados”.

A redação dos dispositivos legais supracitados deixa clara, ainda, outra diferença, além da realização ou não de finalidades econômicas: a natureza dos negócios jurídicos constitutivos das entidades.

No que concerne à organização das associações e das sociedades, é possível dizer que o Código Civil se preocupou em determinar os órgãos indispensáveis à administração de ambas as pessoas jurídicas. As sociedades, em virtude de uma maior gama de possibilidades de organização dos meios produtivos, receberam uma regulamentação mais detalhada, especificando cada uma das diferentes formas possíveis - desde as sociedades simples, passando pelas sociedades limitadas, sociedades por ações e até as sociedades cooperativas. Estas últimas, destacadas anteriormente, são especialmente interessantes por suas características, que as colocam em uma posição intermediária, entre as sociedades e as associações. Isso porque, ao mesmo tempo que não têm finalidades lucrativas e se prestam a proporcionar vantagens aos seus integrantes, desenvolvem atividades econômicas motivo pelo qual é caracterizada como sociedade.

Importante observar também que, tanto nas sociedades quanto nas associações, a característica principal que as diferencia é verificada não no texto dos estatutos e atos constitutivos, mas na atuação da entidade - os artigos 53 e 981 do Código Civil tratam respectivamente de "pessoas que se organizam para [realização de] fins não econômicos" e "exercício de atividade econômica". Por isso, a forma da entidade deverá ser verificada no estatuto e na prática, a partir de sua atuação, pois o negócio jurídico e as declarações de vontade que lhe embasam devem ser interpretados a partir da intenção nelas consubstanciadas e não apenas no literal da linguagem que compõe o estatuto social.Nas palavras do professor Antonio Junqueira de Azevedo:

[...]o negócio não é o que o agente quer, mas sim o que a sociedade vê como a declaração de vontade do agente. Deixa-se, pois, de examinar o negócio através da ótica estreita de seu autor e, alargando-se extraordinariamente o campo de visão, passa-se a fazer o exame pelo prisma social e mais propriamente, jurídico. $^{213}$

213 JUNQUEIRA DE AZEVEDO, Antonio. Negócio Jurídico - existência, validade e eficácia. 4. ed. São Paulo: Saraiva, 2007, p. 21. Nesse mesmo sentido ver também o doutrinador português Carlos Alberto da Mota Pinto, que afirma "pode definir-se a declaração de vontade negocial como o comportamento que, exteriormente observado, cria a aparência de exteriorização de um certo conteúdo de vontade negocial, caracterizando, depois, a vontade negocial com a intenção de realizar certos efeitos práticos com ânimo de 
Por esse motivo, não importa para o ordenamento jurídico que determinado grupo de pessoas se autodenomine associação, se sua forma de atuação está a apontar para outra forma de organização social ${ }^{214}$. O Superior Tribunal de Justiça já apreciou caso análogo e se manifestou afirmando que:

\footnotetext{
é irrelevante para o direito tributário o nomen juris e a natureza jurídica atribuída à sociedade. Implica saber sua finalidade econômica. Sociedade civil que, a despeito de indicar não ter fins lucrativos, prevê nos seus atos constitutivos a 'distribuição de lucros'215.
}

Em outras palavras, mesmo que a entidade tenha indicado em seus estatutos ser uma associação e não ter fins lucrativos, se perseguir tais fins por quaisquer meios, deverá ser considerada como sociedade.

Se assim é, seria um erro conferir legitimidade ativa para a propositura de ações em defesa dos direitos transindividuais a entidades que, por sua atuação, não podem ser consideradas associações stricto sensu, ou seja, que não perseguem fins econômicos. É certo que esse tipo de conduta só pode ser coibida a posteriori, pelos juízes, quando da efetiva atuação dessas entidades em juízo. E esse controle é uma das faces da aferição da representatividade adequada - uma vez que reconhecer a existência de finalidades egoísticas em uma associação não apenas implica sua descaracterização, mas também traz à luz o fato de que ela não pretende representar e defender os direitos de uma coletividade - determinável ou não -, mas sim apenas agir em seu próprio interesse ${ }^{216}$, que, por sua vez, pode corresponder ao interesse de apenas alguns de seus membros.

que sejam juridicamente tutelados e vinculantes. Dá-se assim um conteúdo objectivista de declaração negocial, fazendo-se consistir a sua nota essencial, não num elemento interior - uma vontade real, efectiva, psicológica -, mas num elemento exterior - o comportamento declarativo" (MOTA PINTO, Carlos Alberto da. Teoria geral do direito civil. 4.ed. atualizada por Antonio Pinto Monteiro e Paulo Mota Pinto. Coimbra: Coimbra, 2005, p. 413-414).

${ }^{214}$ Nesse sentido, assevera o doutrinador italiano Massimo Bianca que "L'associzione che svolge in via esclusiva o principale un'attività comerciale non può dunque avvalersi dello schermo della personalità giuridica degli enti morali." (tradução livre: a associação que se volte exclusivamente ou principalmente para uma atividade comercial não pode invocar a personalidade jurídica das entidades morais), ver ver: BIANCA, Cesare Massimo. Diritto Civile...Op. cit., p. 366).

${ }^{215}$ Recurso Especial no 449.901/BA, Min. Luiz Fux, Primeira Turma, julgamento 17.12.2002.

${ }^{216}$ Nas palavras de Lamartine Correa: "A pessoa jurídica é uma realidade que tem funções - função de tornar possível a soma de esforços e recursos econômicos para a realização de atividades produtivas impossíveis com os meios isolados de um ser humano; função de limitação de riscos empresariais; função de agrupamento entre os homens para fins religiosos, políticos, educacionais; função de vinculação de determinados bens ao serviço de determinadas finalidades socialmente relevantes. À medida, porém, que as estruturas sociais e econômicas evoluem, tipos legais previstos para determinadas funções vão sendo utilizados para outras - não previstas pelo legislador - funções. Se tais funções novas entram em contraste 
Por esse motivo, após discorrer sobre a liberdade de associação, a história do desenvolvimento dessas entidades no Brasil e no mundo, sua forma e disciplina legal, o objeto deste estudo recairá sobre o instituto da legitimidade ativa - e a evolução pela qual passou até que se permitisse o acesso de entidades associativas ao judiciário para pleitear direitos de terceiros -, para, posteriormente, analisar a representatividade adequada como componente essencial para atribuir legitimidade ativa às associações, bem como verificar se essa possibilidade existe no direito brasileiro atual. 


\section{A LEGITIMIDADE AD CAUSAM NOS PROCESSOS COLETIVOS}

\subsection{APONTAMENTOS SOBRE AS CONDIÇÕES DA AÇÃO NOS PROCESSOS COLETIVOS}

A maior parte da doutrina processual brasileira, apoiada nas lições de Enrico Tullio Liebmann, reconhece haver três condições da ação, quais sejam: (i) a legitimidade $a d$ causam, (ii) a possibilidade jurídica do pedido e (iii) o interesse de agir. Com base nessa orientação doutrinária, essas três condições da ação foram incluídas no artigo 267, inciso IV do Código de Processo Civil.

Para conceituar as condições da ação, cabe recapitular o histórico das teorias que buscaram definir a natureza da própria ação. No início do século XIX, não havia uma distinção clara entre o direito de ação e o direito material, sendo o direito de ação visto como "o direito subjetivo em estado de defesa". Tratava-se então da chamada teoria imanentista, defendida por Savigny ${ }^{217}$. Foi somente com a polêmica surgida entre dois doutrinadores alemães - Widscheid e Muther - que a ação passou a ser vista como um direito em $\mathrm{si}^{218}$. Posteriormente, formularam-se outras duas teorias que buscavam caracterizar o direito de ação: a teoria concreta e a teoria abstrata.

A teoria concreta tentou explicar o fenômeno da ação como um direito a um provimento de mérito favorável - sendo em primeiro plano um direito do indivíduo contra o Estado e, em um segundo momento, um direito do autor contra o réu. O ponto falho dessa teoria, no entanto, encontra-se na impossibilidade de explicar satisfatoriamente a ação julgada improcedente, já que o fenômeno ocorrido até a declaração de improcedência não poderia ser caracterizado como ação ${ }^{219}$. Seguindo essa linha de raciocínio, as condições da ação para a teoria concreta ficavam circunscritas às condições necessárias para um pronunciamento jurisdicional favorável. Desta feita, estariam intimamente ligadas

\footnotetext{
${ }^{217}$ COSTA, Susana Henriques. Condições da Ação. São Paulo: Quartier Latin, p. 21.

${ }^{218}$ Ambos os estudiosos se pautaram pela análise das actios romanas, tirando o foco do direito material e discutindo o direito de ação em si, muito embora tenham chegado a conclusões diversas. Diz, sobre o tema, Susana Henriques da Costa: "Quanto ao instituto da ação, foram importantes as conclusões de ambos os romanistas. Winscheid teve seu papel ao entender que a ação seria um direito ao provimento do juiz, independentemente do seu direito subjetivo. Muther, por outro lado, foi quem primeiro introduziu a idéia de que a ação seria um direito do autor perante o Estado à obtenção da tutela jurídica e não contra o réu" (COSTA, Susana Henriques. Condições da Ação... op. cit., p. 22).

219 ARAÚJO CINTRA, Antonio Carlos; GRINOVER, Ada Pellegrini; DINAMARCO, Cândido Rangel. Teoria Geral do Processo. São Paulo: Malheiros, 2002 p. 252-253.
} 
ao mérito da demanda e deveriam ser analisadas no momento da sentença, fazendo coisa julgada material ${ }^{220}$.

Em sentido oposto, formulou-se a teoria abstrata da ação, afirmando que o direito à ação existe independentemente do direito material, já que se trata primordialmente de um direito do cidadão contra o Estado - de obter um provimento jurisdicional ${ }^{221}$. Essa teoria abstrata, conquanto tenha sido criticada por grande parte das doutrinas brasileira e italiana, serviu de base para a formulação da teoria eclética de Enrico Tullio Liebman, que passou a ser adotada pela legislação brasileira não apenas para explicar a natureza do direito de ação como também para definir as condições para o exercício desse direito.

Os estudos conduzidos por Liebman buscaram superar as críticas formuladas contra a teoria concreta e a teoria abstrata, mas não há dúvida que partiram primordialmente de uma concepção abstratista da ação. Isso porque defendiam a existência do direito de ação independentemente do resultado do processo e que, por isso, prescindiria do direito material. $\mathrm{O}$ ponto dissonante entre a teoria criada pro Liebman e a teoria abstrata da ação, no entanto, encontra-se no fato de que o doutrinador italiano reconhece que o direito de ação não é incondicionado. A teoria eclética, portanto, está fundamentada na existência de determinadas condições para o exercício do direito de ação e, por meio dele, na possibilidade de conhecimento do mérito da causa pelo juiz.

Como anteriormente destacado, foi a teoria eclética que encontrou eco na doutrina brasileira, tendo sido integralmente adotada pelo Código de Processo Civil pátrio. É o que se depreende da leitura do artigo 267, inciso VI, do nosso diploma processual, no qual consta que o processo será extinto sem a resolução do mérito “[...] quando não concorrer qualquer das condições da ação, como a possibilidade jurídica do pedido, a legitimidade das partes e o interesse processual".

\footnotetext{
${ }^{220}$ São expoentes da teoria concreta da ação os alemães Wach e Oskar von Bülow, e o doutrinador italiano Giuseppe Chiovenda. Este último lista como as condições da ação: $1^{\circ}$ a existência de uma vontade de lei que assegure a alguém um bem, obrigando o réu a uma prestação; $2^{\circ}$ a qualidade, isto é, a identidade da pessoa do autor como a pessoa favorecida pela lei, a identidade da pessoa do réu como a pessoa obrigada; $3^{\circ}$ o interesse em conseguir o bem por obra dos órgãos públicos" (DINAMARCO, Cândido Rangel. Instituições de Direito Processual Civil. 5. ed. Vol I. São Paulo: Ed. Malheiros, 2005, p.89).

${ }^{221}$ As principais críticas que se fazem a essa vertente residem no não reconhecimento de vínculo entre o direito de ação e o direito material. Anote-se, ainda, a crítica pontual de Calamandrei, que opõe-se à teoria abstrata da ação por considerar que ela retira do processo o seu aspecto privado e por julgar que o direito de ação não tem como fundamento o interesse do cidadão em ver seu direito reconhecido, mas sim o interesse do Estado de dar cumprimento ao ordenamento jurídico - entendimento este classificado pelo doutrinador como autoritário e coletivista. Sobre o assunto ver COSTA, Susana Henriques da. Condições da Ação...Op. cit., p. 23-29 e PASCHOAL, Maximilian Fierro. A representatividade adequada nas ações coletivas brasileiras...Op. cit., p. 23-25.
} 
As condições da ação, para a teoria de Liebman, podem ser conceituadas como os elementos de existência do direito de ação e para ele seja apto a alcançar sua finalidade - a prolação de uma sentença de mérito que repercuta no âmbito do direito material. O próprio idealizador da teoria eclética esclarece que a falta de qualquer uma das condições da ação acarretará na inexistência da ação, de modo que tais condições:

[...] são os requisitos de existência da ação, devendo por isso ser objeto de investigação o processo, preliminarmente ao exame do mérito (ainda que implicitamente, como costuma ocorrer). Só se estiverem presentes essa condições é que se pode considerar existente a ação, surgindo para o juiz a necessidade de julgar sobre o pedido (domanda), para acolhê-lo ou rejeitá-lo ${ }^{222}$.

Assim, para afastar as críticas dirigidas contra as teorias anteriores, Liebman reconheceu a existência de um direito de ação constitucional (direito à ação) ${ }^{223}$, esse sim incondicionado - tal qual pretendia a teoria abstrata -, e um direito de ação disciplinado pelo direito processual, que conduz a um provimento jurisdicional sobre o mérito da pretensão do autor. O exercício deste último depende do preenchimento das chamadas condições da ação - reconhecidas como o elo que une o direito material e o direito processual. São elas o interesse jurídico, a possibilidade jurídica do pedido e a legitimidade das partes. Esclarece, sobre o assunto, Cândido Rangel Dinamarco:

[...] a garantia constitucional $d a$ ação não impede que a lei imponha requisitos para a efetiva e individualizada existência desse direito em casos concretos. Trata-se das condições da ação [...]. Elas figuram entre os pressupostos de admissibilidade do julgamento do mérito [...]. A falta de uma das condições da ação caracteriza-se como carência de ação, que tem por consequência a negativa do julgamento do mérito e extinção do processo sem esse julgamento ${ }^{224}$.

No âmbito das ações coletivas, a análise das condições da ação é, também, indispensável. A demanda coletiva, independentemente de suas características específicas, é também uma demanda judicial - decorrente do exercício do direito de ação por quem se

${ }^{222}$ LIEBMAN, Enrico Tullio. Manual de Direito Processual Civil. Rio de Janeiro: Forense, 1984, p.154. No mesmo sentido ver COSTA, Susana Henriques. Condições da Ação...Op. cit., p. 35-36.

${ }^{223} \mathrm{O}$ direito incondicionado de ação é aquele que está disposto no artigo $5^{\circ}$, XXXV, da Constituição Federal. Ele fala em um exercício do direito de ação abstrato e puro. Refere-se primordialmente ao Estado, que deve prover meios para que os cidadãos levem a juízo qualquer lesão ou ameaça a direito, do que às partes ou ao objeto da demanda em si. Sobre o assunto ver COSTA, Susana Henriques. Condições da Ação...Op. cit., p. 40-41.

${ }^{224}$ DINAMARCO, Cândido Rangel. Instituições de Direito Processual Civil. Vol I. 5.ed. São Paulo: Malheiros: 2005, p. 300-301. 
afirma legítimo interessado na defesa de uma situação jurídica de direito material protegida pelo ordenamento jurídico 225 .

Entretanto, os estudos sobre tais condições da ação foram elaborados a partir da perspectiva do processo individual, de modo que a sua aplicação no processo coletivo não pode ser realizada sem uma releitura interpretativa que respeite as peculiaridades desses processos, especialmente diante da relevância dos direitos transindividuais tutelados.

O interesse processual é definido no âmbito do processo civil individual como decorrência da necessidade e da utilidade da atuação jurisdicional, sendo ambas aferidas com base na situação substancial trazida pelo autor da demanda na petição inicial. Em outras palavras, o interesse de agir só se constata in concreto, com vistas à situação real narrada no processo $^{226}$. Não há no microssistema dos processos coletivos nenhuma norma que aborde o interesse de agir e nem a forma como a necessidade e a utilidade da tutela coletiva devem ser aferidas no caso concreto. Dessa maneira, essa tarefa foi legada à doutrina e à jurisprudência.

Identifica-se que também no caso das ações coletivas há que se observar a necessidade e a utilidade da tutela coletiva - sendo que, diante da relevância dos direitos defendidos, o interesse de agir será analisado com vistas ao objeto da demanda proposta, e não do seu autor. Até porque o titular dos interesses deduzidos em juízo e o autor da ação coletiva nem sempre são coincidentes, o que não anula a necessidade de aferir o interesse processual $^{227}$.

Especial atenção, nesse tocante, é dispensada aos direitos individuais homogêneos que, por serem individuais em sua gênese - tendo a lei facultado a defesa conjunta em juízo -, podem não contar com o grau de homogeneidade necessário para que seja possível se valer da tutela coletiva. Devido a essa característica, os direitos individuais homogêneos demandam análise mais detida no que diz respeito à necessidade e, principalmente, à utilidade da tutela coletiva e as vantagens que esta apresenta sobre a tutela individual. Se os caracteres individuais de determinados direitos suplantam os coletivos, determinando que a melhor via para a discussão da responsabilidade e para a fixação de eventual indenização é uma ação individual, faltará interesse de agir para a demanda coletiva,

\footnotetext{
${ }^{225}$ LEONEL, Ricardo de Barros. Manual do Processo Coletivo. 2. ed. São Paulo: RT, 2011, p.146.

${ }^{226}$ Nesse sentido, ver TUCCI, José Rogério Cruz. A causa petendi no direito processual civil brasileiro. 2 ed.: São Paulo: RT, 2001, p. 173; e DIDIER JR., Fredie. Pressupostos processuais e condições da ação - o juízo de admissibilidade do processo. São Paulo: Saraiva, 2010, p. 278-279.

${ }^{227}$ PASCHOAL. Maximilian Fierro. A representatividade adequada na ação coletiva brasileira...Op. Cit., p. 45.
} 
porquanto essa não seja útil - ou, ao menos, tenha sua utilidade diminuída - para a solução do litígio. Nesse sentido, manifesta-se Ada Pellegrini Grinover:

\begin{abstract}
Se o provimento jurisdicional resultante da ação civil pública em defesa de direitos individuais homogêneos não é tão eficaz quanto aquele que derivaria de ações individuais, a ação coletiva não se demonstra útil à tutela dos referidos interesses. E, ademais, não se caracteriza como a via adequada para sua proteção. Explique-se: a ação civil pública por danos individualmente sofridos, como é notório, conduz a uma sentença condenatória, genérica, que reconhece a responsabilidade do réu pelos danos causados e o condena a repará-los às vítimas ou a seus sucessores [...] Segue-se uma liquidação de sentença, a título individual, em que caberá provar, aos que se habilitarem, o dano pessoal e o nexo de causalidade entre este e o dano feral reconhecido pela sentença, além de quantificar os prejuízos.

Ora, a prova do nexo causal pode ser tão complexa, no caso concreto, que tornará praticamente ineficaz a sentença condenatória genérica[... $]^{228}$.
\end{abstract}

A possibilidade jurídica do pedido, por outro lado, foi arrolada por Enrico Tullio Liebman entre as condições da ação nas primeiras edições de seu Manual de Processo Civil, tendo sido excluída desse rol nas últimas edições ${ }^{229}$. Entretanto, a doutrina brasileira utiliza o conceito com alguma frequência, especialmente porque ele ainda se encontra positivado no Código de Processo Civil (Lei $n^{\circ}$ 5.869/1973) como uma das causas que pode levar à extinção do processo sem a resolução do mérito.

No âmbito do processo coletivo, a possibilidade jurídica do pedido se verifica quando o objeto da tutela coletiva pretendida está previsto no ordenamento jurídico ou não é por ele vedada ${ }^{230}$. Assim, a Lei da Ação Civil Pública (Lei n ${ }^{\circ}$ 7.347/1985) determina, em seu artigo $1^{\circ}$, as matérias que podem ser pleiteadas por essa via e, mais do que isso, discrimina aquelas que não poderão ser discutidas por meio de ação civil pública - como as matérias tributárias, previdenciárias, e discussões acerca do Fundo de Garantia por

\footnotetext{
${ }^{228}$ GRINOVER, Ada Pellegrini. Da class action for damages à ação de classe brasileira: os requisitos de admissibilidade. Revista de Processo, São Paulo, nº 101, Ano 26, jan/mar.2001, p. 22-23.

${ }^{229} \mathrm{Na}$ terceira edição de seu Manual de Processo Civil, o doutrinador italiano excluiu a possibilidade jurídica do pedido do rol das condições da ação. Essa mudança se deveu, principalmente, ao fato de ter entrado em vigor, na Itália, a lei que instituiu o divórcio (Lei no 898/1970), principal exemplo de pedido juridicamente impossível utilizado por Liebman. Tendo se tornado possível tal pedido, considerou despiciendo defender a autonomia dessa condição da ação. Nesse sentido ver COSTA, Susana Henriques da. Condições da Ação... Op. cit., p. 57.

${ }^{230}$ Nesse sentido, manifesta-se o professor Rodolfo de Camargo Mancuso, ao afirmar que "a possibilidade jurídica do pedido comporta dupla visualização: uma de cunho afirmativo, nesse sentido de que a pretensão venha - ao menos abstratamente - prevista no ordenamento jurídico ou com este compatibilizada, e outra, de cunho negativo, a saber, que a pretensão não venha desde logo repelida pela ordem jurídica" (MANCUSO, Rodolfo de Camargo. Jurisdição Coletiva e Coisa Julgada - teoria geral das ações coletivas. São Paulo: RT, 2006, p. 386).
} 
Tempo de Serviço (FGTS) ${ }^{231}$. Se assim é, veicular tais pretensões por meio de ação civil pública configuraria formular pedido juridicamente impossível, que deveria conduzir à extinção da demanda sem resolução do mérito.

Assim, as condições da ação nos processos coletivos, conquanto adotem a mesma base teórica do processo individual, são interpretadas de forma substancialmente diversa, já que ganharam contornos próprios ao contexto da tutela coletiva de direitos e da tutela dos direitos coletivos. Conforme descrito na introdução a esse estudo, um dos institutos do processo individual que sofreu maior impacto quando estudado sob o prisma da tutela dos interesses transindividuais foi justamente uma das condições da ação - a legitimidade $a d$ causam.

Esta, por sua posição de destaque no presente estudo e sua intrínseca relação com o instituto da representatividade adequada, será analisada mais detidamente, verificando de que forma o seu conceito, desde que foi gestada, ainda sob o signo dos processos individuais, evoluiu para possibilitar a tutela dos interesses transindividuais, realizada por terceiros não necessariamente titulares dos direitos pleiteados em juízo.

\subsection{LEGITIMIDADE AD CAUSAM: CONCEITO E EVOLUÇÃO}

O conceito de legitimidade permeia todos os campos do direito, uma vez que encontra sua gênese ainda na sociologia e está vinculado à ideia de origem e situação de poder. A legitimidade seria, em princípio, uma qualidade que se agrega ao poder, emergindo da situação e da origem daquele que o exerce. ${ }^{232}$.

Por estar ligada ao exercício de determinado poder, a conformação completa do conceito de legitimidade depende da prática, motivo pelo qual seu desenvolvimento deveuse precipuamente aos processualistas ${ }^{233}$. Isso porque foi na análise do exercício do poder

\footnotetext{
231 Artigo $1^{\circ}$, parágrafo único. Não será cabível ação civil pública para veicular pretensões que envolvam tributos, contribuições previdenciárias, o Fundo de Garantia do Tempo de Serviço - FGTS ou outros fundos de natureza institucional cujos beneficiários podem ser individualmente determinados. Sobre esse assunto, manifesta-se Ricardo de Barros Leonel criticando a postura restritiva do ordenamento jurídico (LEONEL, Ricardo de Barros. Manual do Processo Coletivo...Op. cit., p.217).

${ }^{232}$ ARMELIN, Donaldo. Legitimidade para agir no direito processual civil brasileiro. São Paulo: RT, 1979, p.5.

${ }^{233}$ Citem-se, como exemplos, no direito italiano Francesco Carnelutti com sua obra Teoria Geral do Direito (CARNELUTTI, Francesco. Teoria Geral do Direito. Tradução Rodrigues Queirós e Artur Anselmo de Castro. Rio de Janeiro: Ambito Cultural, 2006) e no direito alemão Oskar von Bülow com sua obra Teoria das Exceções e dos Pressupostos Processuais (BÜLOW, Oskar von. Die Lehre von den Processeinreden und die Processvorausserzungen, 1868) e Friedrich Lent com sua obra Zivilprozessrecht. (LENT, Friedrich. Zivilprozessrecht. 5. ed. München und Berlin: Ch. Beck’sche Verlagsbuchhandlung, 1953).
} 
de ingressar com uma ação - a legitimidade de agir - que a legitimidade passou a ser enfocada como o liame entre o direito material e o direito processual ${ }^{234}$. Foi nessa seara que a legitimidade passou ser definida como "[...] qualidade do sujeito aferida em função de ato jurídico, praticado ou a ser praticado" ${ }^{\text {235 }}$, qualidade esta que "[...] resulta de uma relação jurídica ou de uma posição em uma situação de fato, à qual o direito reconhece efeitos jurígenos" ${ }^{\text {236 }}$. Fala-se em situação do sujeito porque a legitimidade ad causam será aferida no caso concreto e tendo em vista o direito material objeto da ação, pelo que não é possível defini-la como uma qualidade permanente ou intrínseca ao sujeito da relação jurídica processual. Por esse motivo parte da doutrina fala em "situação legitimante"237.

Resumindo as ideias acima, a legitimidade ad causam pode ser definida como a “[...] pertinência subjetiva da ação, isto é, a regularidade do poder de demandar de determinada pessoa sobre determinado objeto" ${ }^{\text {238 }}$. Tal definição, calcada nos ensinamentos de Liebmann, é de autoria de Alfredo Buzaid, redator do anteprojeto do Código de Processo Civil Brasileiro de 1973, e foi encampada no artigo $6^{\circ}$ do diploma processual, vigente sem grandes alterações até hoje e mantido no projeto de novo Código de Processo Civil $^{239}$. Essa norma estabelece a regra geral da legitimidade (legitimidade ordinária) e

\footnotetext{
${ }^{234}$ Sobre o tema, observou Donaldo Armelin que "[...] a legitimidade não representa um simples resultado de especulações jurídicas despidas de importância no mundo da atuação do direito, alcandorada nos páramos de intelectualizações apartadas da realidade. Pelo contrário, sua importância e as consequências práticas dela defluentes no plano jurídico lhe garantiram a expansão de um para outros campos do direito, a fim de solucionar de maneira mais lógica, racional e, portanto, mais simples, problemas ali existentes. Aliás, a possibilidade de se albergarem tais questões de difícil solução dentro dos esquemas tradicionais à sombra do conceito de legitimidade e de suas consequências demonstra de maneira decisiva a sua importância no mundo jurídico" (ARMELIN, Donaldo. Legitimidade para agir no direito processual...Op. cit., p. 8).

${ }_{235}$ Ibid., p. 11.

${ }^{236}$ Ibid., p. 11.

${ }^{237}$ Nas palavras de José Roberto dos Santos Bedaque: “[...] [a legitimidade da parte] depende daquilo que a doutrina denomina de situação legitimante, isto é, a situação com base em que se determina qual o sujeito que, em concreto, pode e deve praticar certo ato. Dela decorre a situação legitimada, ou seja, o poder, a faculdade ou o dever que, em consequência, vem a pertencer ao sujeito. [...] O direito afirmado deve pertencer àquele que propõe a demanda e ser exigido do sujeito passivo da relação material exposta" (BEDAQUE, José Roberto dos Santos. Pressupostos processuais e condições da ação. Justitia, 56 (156), out/dez 1991, p. 57.

${ }^{238}$ BUZAID, Alfredo. Agravo de petição no sistema do Código de Processo Civil. 2.ed. São Paulo: Saraiva, 1956, p. 89. No mesmo sentido, ver FABRÍCIO, Adroaldo Furtado. Extinção do Processo e Mérito da Causa. Revista de Processo, São Paulo, n. 58, abr/jun de 1990, p. 19.

${ }^{239}$ No projeto de Novo Código de Processo Civil, atualmente em discussão no Congresso, a ideia do atual artigo $6^{\circ}$ foi desmembrada nos artigos 17 e 18, cujos textos são: Art. 17. Para propor a ação é necessário ter interesse e legitimidade e Art. 18. Ninguém poderá pleitear direito alheio em nome próprio salvo quando autorizado por lei. Foi acrescido, no entanto, parágrafo único ao artigo 18, em que é regulamentada a hipótese de substituição processual. Esse novo dispositivo preconiza que o juiz dará ciência ao substituído da existência de ação e, se este decidir intervir no processo, cessará a representação. Essa disposição, no entanto, não afeta a esfera dos direitos coletivos, em que os legitimados substituem numerosos grupos de pessoas por vezes de impossível individualização -, o que inviabilizaria a aplicação do citado dispositivo e a intervenção dos substituídos.
} 
determina que ninguém poderá pleitear direito alheio em nome próprio, salvo se autorizado por lei.

A regra geral da legitimidade ad causam positivada em nosso Código de Processo Civil está ligada intrinsecamente à ideia de situação legitimante: o titular do direito material - e somente ele - tem legitimidade para, em juízo, pleitear o que seja relativo a tal direito. Tal concepção, entretanto, foi gestada em um contexto jurídico, histórico e social ainda eminentemente individualista, em que era possível restringir a análise da legitimidade ativa à titularidade do direito material.

Com o advento da chamada sociedade de massa, em que as relações humanas e, por conseguinte, as relações jurídicas passaram a ocorrer em larga escala, os modelos processuais baseados no indivíduo não mais atendiam os reclamos sociais e eram incapazes de servir como instrumentos para a pacificação social ${ }^{240}$. Foi esse contexto social que propiciou o reconhecimento da existência de direitos que extrapolam a esfera individual e atingem um grande número de pessoas e, como tal, necessitam de um sistema próprio de tutela $^{241}$.

$\mathrm{Na}$ base da criação desse sistema de tutela dos interesses transindividuais encontrava-se a necessidade de ampliar o conceito de legitimidade ad causam. Isso se dá porque a defesa dos direitos da coletividade em juízo somente é viável por meio de um sistema de substituição processual ${ }^{242}$, já que os titulares de tais direitos nem sempre são identificáveis e, quando identificáveis, podem ser tão numerosos a ponto de inviabilizar o litisconsórcio.

No início da criação do microssistema de tutela dos interesses transindividuais está a Lei da Ação Popular (Lei no 4.717/1965). Esta, conquanto esteja inequivocamente inserida dentro do contexto da defesa dos interesses metaindividuais e preveja a possibilidade da defesa em juízo dos interesses de todos por um representante - qualquer

${ }^{240}$ SHIMURA, Sérgio. Tutela coletiva e sua efetividade...Op. cit., p. 33-34 e CAPPELLETTI. Mauro. Formações sociais e interesses coletivos...Op. cit., p 128-159.

${ }^{241}$ Ver capítulo 2 (introdução histórica). Sobre o tema, ainda, GRINOVER, Ada Pellegrini. Significado social, político e jurídico da tutela...Op. cit., p. 9-10.

${ }^{242}$ Os benefícios preconizados pela criação de um sistema próprio de tutela dos interesses transindividuais, tais como: (i) o aumento do acesso à justiça; (ii) a tentativa de reequilibrar a relação entre as partes, neutralizando as vantagens dos réus (litigantes habituais); (iii) o aumento na eficiência da prestação jurisdicional, evitando o ajuizamento de inúmeras demandas idênticas e dispersas, entre outros, só pode se dar por meio das ações representativas - em que um representante, independentemente de outorga de procuração em diversos casos, defende em juízo os interesses de toda uma coletividade. A validade dessas ações em nosso sistema jurídico dependeu da ampliação do conceito de legitimidade. Ver sobre o tema CASTRO MENDES, Aluísio Gonçalves de. Ações coletivas no direito comparado e nacional... Op.Cit., p. 36; CAPPELlETTI, Mauro; GARTH, Bryant. Acesso à Justiça...Op. cit., p. 28, e YEAZELL, Stephen. Group litigation and social context...Op. cit., p. 868. 
cidadão tem legitimidade para pedir a anulação de atos lesivos ao patrimônio público -, não pode ser considerada propriamente uma ação representativa. Isso porque o legitimado ativo, muito embora atue na defesa do patrimônio público e, em última análise, no interesse de todos os contribuintes, não defende os interesses dos indivíduos em si ${ }^{243}$.

Foi com o advento da Lei da Política Nacional do Meio Ambiente (Lei $\mathrm{n}^{\circ}$ 6.938/1981) e, em seguida, da Lei da Ação Civil Pública (Lei $n^{\circ} 7.347 / 1985$ ) que se convalidou a ideia de legitimidade extraordinária no âmbito dos processos coletivos, preenchendo de significado a exceção inscrita no artigo $6^{\circ}$ do Código de Processo Civil. Tal dispositivo, após fixar o conceito de legitimidade ad causam, afirmando que ninguém poderá pleitear em nome próprio direito alheio, deixou explícita a ressalva de que isso poderia ser feito, desde que autorizado por lei. Os dois diplomas legais supracitados passaram a autorizar expressamente que determinadas entidades e órgãos governamentais pudessem pleitear em nome próprio os direitos de uma coletividade identificável ou não, podendo requerer desde a cessação de condutas danosas até a indenização coletiva e individual àqueles afetados por tais condutas ${ }^{244}$.

Assim, para atender à premente necessidade de se ampliar o acesso à justiça por meio das ações coletivas, o conceito de legitimidade ativa foi adaptado para abarcar não apenas as situações em que se observa o liame entre o sujeito e o objeto da ação, mas também os casos em que a lei autoriza que determinados entes atuem em nome próprio em prol do interesse de muitos indivíduos. A doutrina alemã chegou a criar um conceito para essa segunda situação, falando não em "legitimidade ativa", mas em "direito de conduzir o processo" (Prozessführungsrecht) ${ }^{245}$. Nas palavras de Fredie Didier Jr,. a expressão, conquanto não resolva todos os problemas relativos à legitimidade ativa das entidades

\footnotetext{
${ }^{243}$ Nesse sentido, explica Susana Henriques da Costa que o interesse primário tutelado pela Ação Popular é um interesse geral, não havendo hipótese de satisfação de um interesse individual quando da sua efetivação: "O que aqui se denomina interesse geral é um interesse de toda a comunidade política, um interesse que a todos diz respeito e não somente a uma determinada coletividade, como ocorre com os interesses difusos e coletivos. O interesse geral abstrai satisfação direta de algum interesse individual quando da sua efetivação. [...] Os interesses difusos e coletivos, portanto, ao contrário dos interesses gerais, são interesses que implicam na fruição efetiva e direta de um benefício/prejuízo por parte de seus membros". (COSTA, Susana Henriques. O processo coletivo na tutela do patrimônio público e da moralidade administrativa - ação de improbidade administrativa, ação civil pública e ação popular. São Paulo: Quartier Latin, 2009, p.61-65 e 143-154).

${ }^{244}$ Artigo $14, \S 1^{\circ}$, da Lei $n^{\circ} 6.938 / 1981$ e Artigo $1^{\circ}$ da Lei $n^{\circ} 7.347 / 1985$.

${ }^{245}$ ARMELIN, Donaldo. Legitimidade para agir no direito processual...Op. cit., p. 115-116.
} 
legalmente autorizadas a propor tais ações, "é bastante sugestiva e eloquente, pois sintetiza o poder jurídico que é atribuído ao sujeito: conduzir determinado processo"246.

Partindo dessas primeiras leis, a legitimidade ativa para a propositura de ações coletivas foi se ampliando cada vez mais para permitir que diversas entidades - fossem elas ligadas ao poder do Estado ou à sociedade civil - pudessem acessar o judiciário na defesa dos interesses transindividuais. Com a autorização legal para que esses entes agissem em juízo, superou-se a questão da legitimidade ativa, mediante a interpretação conjunta dessas novas leis e do Código de Processo Civil, restando a discussão acerca da natureza jurídica dessa legitimidade ativa e, ainda, se ela poderia sofrer limitações na prática.

\subsection{A NATUREZA JURÍDICA DA LEGITIMIDADE AD CAUSAM NOS PROCESSOS COLETIVOS}

Partindo da conceituação da legitimidade ad causam e de seu papel no microssistema de tutela dos interesses transindividuais, a doutrina passou a debater qual seria a natureza jurídica do instituto no âmbito dos processos coletivos, vez que o legislador brasileiro optou por conferir legitimidade ativa a determinadas entidades para a defesa em juízo dos direitos transindividuais ${ }^{247}$. Discute-se, assim, se a legitimidade ativa nos processos coletivos seria extraordinária, ordinária ou de um terceiro tipo, neste último caso específico para a tutela dos interesses da coletividade.

A legitimidade extraordinária pode ser definida por meio de alguns caracteres principais: (i) o caráter excepcional e a aplicação restrita aos casos regulados por lei (artigo $6^{\circ}$ do Código de Processo Civil $^{248}$ ); (ii) a atuação em juízo do legitimado extraordinário na qualidade de parte, e não de representante, atuando em nome próprio na defesa do direito alheio $^{249}$; (iii) a outorga ao legitimado extraordinário de poderes relacionados à gestão do

\footnotetext{
${ }^{246}$ DIDIER JR., Fredie. Pressupostos processuais e condições da ação. São Paulo: Ed. Saraiva, 2010, p. 229.

${ }^{247}$ De acordo com o artigo $5^{\circ}$ da Lei $n^{\circ} 7.347 / 1985$, reproduzido posteriormente pelo Código de Defesa do Consumidor, têm legitimidade para propor ações coletivas: O Ministério Público, a Defensoria Pública, a União, os Estados, os Municípios e o Distrito Federal, as autarquias, empresas públicas, fundações e sociedades de economia mista e, por fim, as associações (desde que constituídas há mais de um ano e que tenham entre suas finalidades institucionais a tutela dos interesses pleiteados em juízo).

${ }^{248}$ Artigo $6^{\circ}$ do Código de Processo Civil. Ninguém poderá pleitear, em nome próprio, direito alheio, salvo quando autorizado por lei.

${ }^{249}$ Nas palavras de Pontes de Miranda: "De regra, são as partes os sujeitos do direito e do dever, da pretensão, da obrigação, ou da exceção, que se discute. Todavia pode dar-se que terceiro, que não é o sujeito
} 
processo, não lhe sendo, em regra, atribuídos poderes para dispor do direito material discutido; e (iv) a extensão dos efeitos da coisa julgada ao substituído ${ }^{250}$.

Segundo Donaldo Armelin, em obra publicada antes mesmo de se cogitar a existência de um microssistema de defesa dos interesses transindividuais, a legitimidade extraordinária seria possível em algumas situações, entre elas aquelas em que o interesse público se sobrepõe ao interesse particular ${ }^{251}$. À época, remetia-se ao legitimado individual na ação popular, o qual tinha legitimidade para defender em nome próprio os interesses coletivos em juízo.

A maior parte da doutrina pátria se alinha à corrente que considera a legitimidade das entidades listadas nos artigos $5^{\circ}$ da Lei da Ação Civil Pública e $82^{\circ}$ do Código de Defesa do Consumidor como sendo extraordinária. Tal entendimento parte da interpretação conjunta do artigo $6^{\circ}$ do Código de Processo Civil com os dispositivos legais supracitados. Em outras palavras, as leis que integram o microssistema de tutela coletiva autorizaram que determinadas entidades pleiteassem, em nome próprio, direitos de titularidade de toda uma coletividade, pelo que se estaria falando em legitimidade ativa extraordinária e, consequentemente, de substituição processual da coletividade pelo legitimado. Manifesta essa opinião Cândido Rangel Dinamarco, ao assinalar que a idoneidade das entidades eleitas pelo legislador como legitimadas ativas para a propositura das ações coletivas qualifica-as como legítimas substitutas processuais dos interessados e a participação dessas no processo satisfaz às exigências do contraditório ${ }^{252}$. No mesmo sentido, Pedro da Silva Dinamarco assevera:

O interesse poderá pertencer a pessoas determinadas ou indetermináveis, mas sempre pertencerá a terceiros que não fazem parte da relação jurídica processual. E é isso que importa para caracterizar a legitimidade como extraordinária, pois alguém será substituto processual sempre que a lei autorizar essa pessoa a ajuizar

ativo ou passivo da res deducta, possa ser parte, isto é, ter a ‘ação'. Daí se tira que o conceito de parte é de direito formal, e de ordinário coincide, porém não precisa coincidir, com o de titular do direito na relação jurídica controvertida, ou com o sujeito passivo dessa relação" (PONTES DE MIRANDA. Tratados das Ações. tomo I. Campinas: Bookseller, 1998, p. 266-267).

${ }^{250}$ Sobre o assunto, ver DIDIER JR., Fredie. Pressupostos processuais e condições da ação...Op. cit., p. 253-260.

${ }^{251}$ Segundo o autor, as outras hipóteses em que seria cabível a legitimação extraordinária são: (i) aquelas decorrentes da comunhão de direito ou conexão de interesses; (ii) aquela atribuída em função de vínculo existente entre o legitimado ordinário e o legitimado extraordinário; (iii) em razão de deveres de guarda e conservação dos direitos alheios, atribuídos pela lei ao legitimado extraordinário. ARMELIN, Donaldo. Legitimidade para agir no direito processual...Op. cit., p. 122-130.

${ }^{252}$ DINAMARCO, Cândido Rangel. Instituições de Direito Processual Civil. Vol I. São Paulo: Malheiros, 2005, p. 219. 
uma demanda em nome próprio para defender direito alheio, conforme previsão genérica do art. $6^{\circ}$ do Código de Processo Civil. Assim, nessas hipóteses as partes legítimas não correspondem aos integrantes da relação de direito material controvertida, ou seja, não correspondem precisamente a uma situação legitimante ${ }^{253}$.

Por outro lado, há uma corrente doutrinária que defende tratar-se de legitimidade ordinária aquela conferida às entidades arroladas pela Lei da Ação Civil Pública e pelo Código de Defesa do Consumidor. Para justificar essa posição, parte-se do princípio que os legitimados ativos, quando em juízo para a defesa dos direitos de uma coletividade, não defendem exclusivamente os interesses de terceiros, mas também os seus próprios. Essa linha de raciocínio defendida pelo professor Rodolfo de Camargo Mancuso e por Hugo Nigro Mazzilli ${ }^{254}$, no entanto, não pode ser aplicada a todos os direitos transindividuais ou, mesmo, a todos os colegitimados ativos.

No que concerne às diferentes espécies de direitos transindividuais, no caso dos direitos difusos é possível vislumbrar a atuação dos legitimados ativos na defesa dos direitos de terceiros e, também, no zelo do interesse próprio. Essa identidade, entretanto, nem sempre é completa já que não ocorre quando se fala dos direitos coletivos e individuais homogêneos. Nesses casos, o legitimado ativo defenderá direitos de uma coletividade da qual não necessariamente fará parte.

Ainda, uma terceira corrente considera que, no âmbito das ações coletivas, a legitimidade ad causam não seria ordinária, tampouco extraordinária, mas de um terceiro gênero - destinada exclusivamente à proteção dos interesses transindividuais. Essa vertente é defendida por Arruda Alvim e Ricardo Barros Leonel, que afirmam que a dicotomia legitimidade ordinária-extraordinária somente tem cabimento para explicar fenômenos envolvendo as ações individuais. Em um primeiro momento, também Nelson Nery Junior adotava tal corrente, tendo manifestado que:

Quando a lei legitima alguma entidade a defender direito não individual (coletivo
ou difuso), o legitimado não estará defendendo direito alheio em nome próprio,
porque não se pode identificar o titular do direito. Não poderia ser admitida ação
judicial proposta pelos "prejudicados pela poluição", pelos "consumidores de
energia elétrica", enquanto classe ou grupo de pessoas. A legitimidade para a
defesa dos interesses difusos e coletivos em juízo não é extraordinária, mas sim
legitimação autônoma para a condução do processo (sebständige

${ }^{253}$ DINAMARCO, Pedro da Silva. Ação Civil Pública. São Paulo: Saraiva, 2001, p. 204-205.

${ }^{254}$ MANCUSO, Rodolfo de Camargo. Interesses Difusos. São Paulo: RT, 1994, p. 261 e MAZZILI, Hugo Nigro. A defesa dos interesses difusos em juízo. São Paulo: Saraiva, 2002, p. 62. 
prozeßführungsbefugnis): a lei elegeu alguém para a defesa de direito porque seus titulares não podem individualmente fazê-lo. ${ }^{255}$

Esse raciocínio é falho do ponto de vista dos interesses individuais homogêneos, em que os direitos são individuais e divisíveis, sendo seus titulares plenamente identificáveis, sendo possível a tutela por aqueles legalmente legitimados através da ação coletiva. Nesse caso, novamente, não há como negar a existência de substituição processual e, portanto, de legitimidade extraordinária.

Essa corrente é defendida, ainda, por Antonio Gidi, que enfoca a extensão dos efeitos da coisa julgada coletiva para justificar a existência de um terceiro tipo de legitimação, da qual resultaria uma substituição processual anômala secundum eventum litis, em que o substituído apenas é atingido pela coisa julgada quando a sentença lhe for favorável $^{256}$.

De qualquer maneira, a discussão acerca da natureza jurídica da legitimidade ad causam nos processos coletivos tinha maior relevância no cenário anterior à entrada em vigor da Lei da Ação Civil Pública, em que a doutrina buscava interpretações do artigo $6^{\circ}$ do Código de Processo Civil para justificar a possibilidade do ajuizamento de ações na defesa dos direitos transindividuais por entidades - ou mesmo por indivíduos - sem a necessidade de autorização legal ${ }^{257}$. Após a positivação da Lei da Ação Civil Pública e, posteriormente, do Código de Defesa do Consumidor, e a autorização por elas conferida expressamente aos legitimados ativos para a propositura das demandas coletivas, essa discussão perdeu força, tendo a doutrina passado a enfocar aspectos mais relevantes do microssistema, como a efetividade do processo $^{258}$.

Em vista do exposto, entendeu-se mais adequada para fins desse estudo a teoria que considera a legitimidade extraordinária das entidades listadas pela Lei da Ação Civil

${ }^{255}$ NERY JUNIOR, Nelson; NERY, Rosa Maria de Andrade. Código de Processo Civil Comentado. 5.ed. São Paulo: Saraiva, 2001, p. 1885. Ver também NERY JUNIOR, Nelson. Princípios do Processo Civil na Constituição Federal. São Paulo: RT, 1992, p. 116-120.

${ }^{256}$ GIDI, Antonio. Coisa julgada e litispendência nas ações coletivas. São Paulo: Saraiva, 1995, p. 44.

${ }^{257}$ Nessa época, manifestaram-se em favor da possibilidade da propositura de ações coletivas: José Carlos Barbosa Moreira, afirmando que a legitimidade seria extraordinária, e o professor Kazuo Watanabe, que procurou interpretar o artigo $6^{\circ}$ do Código de Processo Civil de uma forma que tornasse possível a tutela dos interesses transindividuais, através da legitimação ordinária dos entes socialmente idealizados para a propositura dessas ações. Ver "A legitimidade para a defesa dos interesses difusos no direito brasileiro" (BARBOSA MOREIRA, José Carlos. Temas de Direito Processual. $3^{\text {a }}$ Série. São Paulo: Saraiva, 1984, p. 33 e 190. No mesmo sentido VIGORITTI, Vincezo. Interessi collettivi e processo - la legittimazioni ad agire. Milão: Giufrè:, 1979, p. 149.

${ }^{258}$ Ver "Processo civil e interesse público: introdução" (WATANABE, Kazuo. In: Salles, Carlos Alberto (org). Processo Civil e interesse público - o processo como instrumento de defesa social. São Paulo: RT, 2003, p. 18. 
Pública e pelo Código de Defesa do Consumidor. Isso porque, não havendo coincidência entre o legitimado para atuar no processo e o sujeito da relação jurídica material - sendo que nas ações coletivas o agrupamento humano titular do direito sequer está autorizado a agir em juízo na defesa de seus interesses -, tratar-se-á de legitimidade extraordinária. Isto mesmo se considerando que a legitimidade extraordinária no processo coletivo tem, em alguma medida, reflexos diferenciados com relação aos limites subjetivos da coisa julgada (artigo 103 do Código de Defesa do Consumidor), com vistas a preservar da melhor forma possível o titular do direito ${ }^{259}$. Ademais, essa parece ser a hipótese que melhor se adequa a todos os tipos de interesses transindividuais passíveis de tutela jurisdicional.

Além de extraordinária, a legitimidade ativa para a propositura de processos coletivos também foi caracterizada pela doutrina brasileira como sendo concorrente e disjuntiva ${ }^{260}$. Isso porque o microssistema dos processos coletivos conferiu legitimidade ativa a diversas entidades para a propositura de ações na defesa dos direitos transindividuais. Todas essas entidades são titulares do direito de ação de forma simultânea e independente - a legitimidade de uma delas não exclui a das demais. Por esse motivo, fala-se em legitimidade concorrente.

Ademais, a referida legitimidade ativa poderá ser exercida por qualquer dos colegitimados sem necessidade de concurso com os outros - e mesmo independentemente da autorização dos titulares do direito material, que serão substituídos em juízo pela entidade legitimada. E por isso fala-se em legitimidade disjuntiva dos entes listados pela legislação pátria.

Fixadas essas premissas acerca da legitimidade ad causam, cabe discorrer sobre as entidades a quem foi conferida a legitimidade para a propositura das ações em defesa dos interesses transindividuais ao lado das associações civis - estas últimas objetos do presente estudo -, verificando, posteriormente, os requisitos estabelecidos pela lei para que possam atuar em juízo - e sua relação com a representatividade adequada.

\footnotetext{
${ }^{259}$ DIDIER JR., Fredie. Pressupostos processuais e Condições da Ação...Op. cit., p. 264.

${ }^{260}$ A classificação da legitimidade extraordinária como disjuntiva e concorrente foi feita por José Carlos Barbosa Moreira, ver BARBOSA MOREIRA, José Carlos. Tutela jurisdicional dos interesses difusos e coletivos. Revista de Processo, São Paulo: RT, n. 39, jul/set. 1985, p. 58-63. Anota-se, no entanto, que a doutrina, por vezes, utiliza outros adjetivos para caracterizar a legitimidade ativa para a propositura de ações coletivas, como por exemplo: (i) concorrente, autônoma e disjuntiva; (ii) concorrente, disjuntiva e exclusiva; (iii) autônoma e concorrente. Neste sentido, ver LENZA, Pedro. Teoria Geral da Ação Civil Pública. 2.ed. São Paulo: RT, p.178-179.
} 


\subsection{OS LEGITIMADOS ATIVOS PARA TUTELA DOS INTERESSES TRANSINDIVIDUAIS EM JUÍZO}

Conforme anteriormente ressaltado, a atribuição de legitimidade ativa a determinadas entidades, escolhidas pelo legislador brasileiro para representar em juízo os interesses de uma coletividade, preconizou o rompimento com os conceitos do direito processual clássico, protagonizado pelo indivíduo e seus interesses. Para que fosse possível a tutela dos direitos transindividuais, portanto, foi necessário desvincular a legitimação para a propositura da ação da figura do titular do direito material e encampar a ideia da substituição processual por um representante de todos os futuros e eventuais beneficiários da ação.

Nesse cenário, resta analisar quem deverá ser o representante dos interesses da coletividade. Diversas foram as soluções adotadas pelos diversos ordenamentos jurídicos ocidentais que contemplam a defesa dos direitos coletivos e a defesa coletiva de direitos. Há desde sistemas legais que adotam a legitimidade individual para a defesa dos direitos transindividuais - como ocorre, por exemplo, nos Estados Unidos da América -, até sistemas que legitimam apenas entidades certificadas pelo poder público ${ }^{261}$.

O ordenamento jurídico brasileiro optou por uma solução pluralista para a questão da legitimidade extraordinária para a propositura de ações em defesa dos direitos transindividuais, optando por indicar um rol de legitimados que congregasse tanto entes públicos quanto privados, com a intenção de legitimar o maior número possível de entidades, visando ampliar a tutela dos direitos transindividuais pela via coletiva.

É verdade que nos primeiros diplomas legais, hoje integrantes do chamado microssistema de direito processual coletivo, o legislador era mais restritivo quanto à legitimidade ativa para a propositura de ações que visavam a defesa dos interesses transindividuais. A Lei da Ação Popular (Lei no 4.717/1965) legitimava todo e qualquer cidadão para a propositura de ações pretendendo a declaração de nulidade ou a anulação de atos lesivos ao patrimônio público. Por outro lado, a lei que estabeleceu a Política Nacional do Meio Ambiente (Lei no 6.938/1981) atribui legitimidade ao Ministério Público para a

261 Vide o capítulo introdutório do presente trabalho. Ver também GRINOVER, Ada Pellegrini; WATANABE, Kazuo; MULLENIX, Linda. Os processos coletivos nos países de Civil Law e Common Law - uma análise de direito comparado. 2. ed. São Paulo: RT, 2011. 
propositura de ações que tenham como objetivo o ressarcimento por danos causados ao meio ambiente ${ }^{262}$.

Foi apenas com o advento da Lei da Ação Civil Pública (Lei no 7.347/1985) que a legitimidade ativa extraordinária para a defesa de direitos transindividuais foi ampliada, passando a ser disjuntiva e concorrente. A primeira versão do referido diploma legal listava entre os legitimados para a defesa dos direitos ali contemplados: (i) o Ministério Público; (ii) a União, os Estados e os Municípios; (iii) a autarquia, empresa pública, fundação ou sociedade de economia mista; (iv) as associações constituídas a mais de um ano e que congregassem entre seus objetivos institucionais a defesa dos direitos pleiteados em juízo ${ }^{263}$.

Esse mesmo rol de legitimados foi mantido integralmente quando da elaboração do Código de Defesa do Consumidor (Lei $\mathrm{n}^{\circ}$ 8.078/1990), ratificando que essas entidades ligadas tanto ao poder do Estado quanto à sociedade civil tinham legitimidade para ir a juízo em defesa dos direitos transindividuais - entre eles, agora, o direito dos consumidores. Desta feita, é possível dizer que desde a edição da lei da Ação Civil Pública em 1985, e ao longo das duas décadas subsequentes, o rol de legitimados permaneceu inalterado.

Foi apenas no ano de 2007 que a lista veio a ser alterada, passando a constar entre os legitimados para a propositura de ações coletivas a Defensoria Pública, alteração esta que passou a constar apenas no artigo $5^{\circ}$ da Lei da Ação Civil Pública, permanecendo inalterado o artigo $82^{\circ}$ do Código de Defesa do Consumidor ${ }^{264}$.

\footnotetext{
${ }^{262}$ Artigo $14, \S 1^{\circ}$ - Sem obstar a aplicação das penalidades previstas neste artigo, é o poluidor obrigado, independentemente da existência de culpa, a indenizar ou reparar os danos causados ao meio ambiente e a terceiros, afetados por sua atividade. O Ministério Público da União e dos Estados terá legitimidade para propor ação de responsabilidade civil e criminal, por danos causados ao meio ambiente.

${ }^{263}$ Inicialmente, os direitos que poderiam ser pleiteados por meio das ações civis públicas referiam-se aos danos morais e patrimoniais causados ao Meio Ambiente e a bens e direitos de valor artístico, estético, histórico, turístico e paisagístico. Com a entrada em vigor do Código de Defesa do Consumidor, em 1990, no rol de direitos passaram a constar também o direito do consumidor e de quaisquer outros interesses difusos e coletivos. Posteriormente, já no ano de 2001, através do texto da Medida Provisória n ${ }^{\circ}$ 2.180-35, foi acrescentada a defesa da ordem econômica e da economia popular, e a ordem urbanística.

${ }^{264}$ A norma que fez constar do artigo $5^{\circ}$ da lei da Ação Civil Pública a legitimidade da Defensoria Pública foi a lei $n^{\circ} 11.448 / 2007$. Conforme destacado por diversos autores, não seria necessário que a alteração constasse também do Código de Defesa do Consumidor, uma vez que: (i) a interação entre o Código de Defesa do Consumidor e a lei da Ação Civil Pública é clara, e conforma a existência de um microssistema de tutela aos direitos transindividuais; (ii) desde 1994 já consta da lei da Ação Civil Pública a possibilidade de defesa dos direitos do consumidor (Artigo $1^{\circ}$, II). Sobre o assunto, ver GRINOVER, Ada Pellegrini; WATANABE, Kazuo; NERY JUNIOR, Nelson. Código Brasileiro de Defesa do Consumidor comentado pelos autores do anteprojeto. v II. 10. ed. Rio de Janeiro: Forense, 2011, p. 83.
} 
Cabe discorrer brevemente sobre a atuação de cada um dos legitimados arrolados na Lei da Ação Civil Pública e no Código de Defesa do Consumidor, para entender de que forma esses entes interagem com as associações civis - objeto do presente estudo - e qual o papel de cada um deles no microssistema de defesa dos interesses transindividuais.

\subsubsection{Os legitimados ativos ligados ao poder do Estado: Ministério Público, Defensoria Pública e Administração Pública direta e indireta}

É perceptível que a cultura jurídica brasileira - como reflexo da realidade social e de fatores históricos, políticos e econômicos - ainda hoje conserva uma relação íntima com o poder do Estado. Essa ligação se faz notar no microssistema dos processos coletivos em diversos pontos, entre eles no rol dos legitimados ativos para a propositura de ações em defesa dos interesses transindividuais, em que a grande maioria dos entes legitimados estão intimamente ligados ao Estado.

E também em virtude dessa cultura que valoriza a atuação estatal, são os entes legitimados ligados ao poder do Estado que, hoje, são responsáveis pela propositura da grande maioria das demandas em defesa de todos os direitos transindividuais. Particularmente destacada a atuação do Ministério Público.

O Ministério Público, entidade à qual a Constituição Federal atribui a competência para a "[...] defesa da ordem jurídica, do regime democrático e dos interesses sociais e individuais indisponíveis" (artigo 127 da Constituição Federal de 88), foi incluído em todas as leis que tratam da defesa dos interesses da coletividade em juízo como legitimado para a defesa de tais direitos ${ }^{265}$.

Esse fato, aliado a determinados poderes que somente foram atribuídos a ele como a promoção de inquérito civil ${ }^{266}$-, tornou o Parquet o legitimado ativo mais atuante na defesa dos direitos coletivos entre todos os colegitimados. Ilustram essa afirmação os números apresentados em relatório pelo Ministério Público de São Paulo acerca dos inquéritos civis instaurados e, posteriormente, das ações civis públicas propostas em defesa dos interesses da coletividade ${ }^{267}$ :

\footnotetext{
265 Artigo $5^{\circ}$ da Lei 7.347/1985; art. 82 ${ }^{\circ}$ da Lei 8.078/1990; art. $1^{\circ}$ da Lei 7.913/1989; art. 29 ${ }^{\circ}$ da Lei 8.884/1994; art. $210^{\circ}$ da Lei 8.069/1990, art. $7^{\circ}$ e $17^{\circ}$ da Lei 8.429/1992; art.81 ${ }^{\circ}$ I da Lei $10.741 / 2003$ e artigo $129^{\circ}$, incs. III e V da Constituição Federal.

${ }^{266}$ LEONEL, Ricardo Barros. Manual do Processo Coletivo...Op. cit., p. 174.

${ }^{267}$ O relatório completo pode ser acessado no endereço eletrônico do Ministério Público de São Paulo (http://www.mp.sp.gov.br/portal/page/portal/home/banco_imagens/flash/RelatorioDiagnostico2011/rdmp43.
} 


\begin{tabular}{|c|c||c||c|c|}
\hline \multirow{2}{*}{ Ano } & \multicolumn{2}{|c||}{ Inquéritos Civis } & \multicolumn{2}{c|}{ Ações Civis Publicas } \\
\cline { 2 - 4 } & Instaurados & Arquivados & Propostas - MP & Sent. Procedentes \\
\hline 2003 & 4.327 & 2.749 & 2.395 & 592 \\
\hline 2004 & 5.425 & 3.504 & 3.306 & 335 \\
\hline 2005 & 4.976 & 3.187 & 2.454 & 459 \\
\hline 2006 & 6.540 & 3.184 & 2.656 & 495 \\
\hline 2007 & 16.368 & 7.330 & 2.938 & 646 \\
\hline 2008 & 14.327 & 9.445 & 3.117 & 875 \\
\hline 2009 & 12.631 & 9.890 & 3.827 & 1.373 \\
\hline 2010 & 5.161 & 9.514 & 2.507 & 874 \\
\hline
\end{tabular}

Fonte: Ministério Público de São Paulo, 2011

Parte da doutrina brasileira considera que essa marcante atuação do Ministério Público deve-se ao fato de que essa instituição estaria mais bem preparada e aparelhada para a defesa dos direitos da coletividade - particularmente daqueles direitos difusos e coletivos, cuja identificação e delimitação da titularidade são altamente problemáticas ou, mesmo, impossíveis ${ }^{268}$. Por outro lado, outra parte da doutrina teceu duras críticas à grande amplitude que se deu à atuação do Ministério Público na seara da defesa dos interesses transindividuais.

Algumas dessas críticas foram elaboradas por doutrinadores que formularam boa parte da doutrina acerca dos direitos coletivos, entre eles Mauro Cappelletti. O estudioso italiano apresentava resistência à atuação do Ministério Público por considerar a entidade muito próxima do poder executivo - que, por vezes, é quem perpetra os danos aos interesses da coletividade -, a similitude das funções do parquet com as funções jurisdicionais e, por fim, a falta de especialização, estrutura e preparo técnico para a defesa dos interesses coletivos, bem como uma mentalidade anacrônica e pouco progressista ${ }^{269}$. Tais ponderações, entretanto, coadunavam-se com as características do Ministério Público italiano na década de 1970, com relação ao Brasil, o próprio autor reconheceu que o

pdf , consultado em 12set.2012) e apresenta dados como a taxa de sucesso do Parquet paulista nas ações civis públicas propostas e os temas mais tratados nas referidas ações.

${ }^{268}$ Alinham-se à essa corrente Nelson Nery Júnior, Édis Milaré, Ricardo Barros Leonel, entre outros. Este último, sobre o tema, atesta que "O Ministério Público, de todos os legitimados, é a instituição que possui maiores condições concretas para a proteção dos interesses metaindividuais, seja por sua estrutura e independência, seja pelos poderes que para tal escopo the foram conferidos pelo legislador, como o poder de requisição, de notificação, e por dispor do procedimento investigatório denominado "inquérito civil", que não são reservados aos demais habilitados. Ver LEONEL, Ricardo de Barros. Manual de Processo Coletivo...Op. cit., p. 174.

${ }^{269}$ CAPPELLETTI, Mauro. Formazioni sociali e interessi di gruppo davanti alla giustizia civile. Rivista di Diritto Processualle Civile, Padova: Cedam, 3/361-402, ano XXV, 1975, p. 368-377. 
Ministério Público pátrio difere estruturalmente do órgão italiano e, com isso, estaria habilitado a atuar na defesa dos interesses difusos e coletivos ${ }^{270}$.

Embora a legitimidade do Ministério Público na defesa dos interesses difusos e coletivos tenha se pacificado na doutrina pátria, é certo que a atuação do parquet em processos que discutam interesses individuais homogêneos continua provocando o debate do tema por estudiosos. O cerne dessas discussões se encontra no fato de que os interesses individuais homogêneos são, em sua origem, de titularidade conhecida e delimitada, existindo, por sua dispersão e origem comum, a possibilidade de tutelá-los coletivamente. Tendo isso em vista, é indagado se o Ministério Público, como órgão que atua nos interesses de toda a sociedade, teria legitimidade para atuar em substituição processual para o resguardo de direitos individuais.

O artigo 129, III, da Constituição Federal atribuiu ao Ministério Público a legitimidade para “[...] promover o inquérito civil e a ação civil pública, para a proteção do patrimônio público e social, do meio ambiente e de outros interesses difusos e coletivos". O texto constitucional não faz menção à tutela dos interesses individuais homogêneos, e nem poderia, uma vez que esse conceito só veio a ser desenvolvido posteriormente, quando foi positivado em 1990, no Código de Defesa do Consumidor. Daí decorreria que, em um primeiro momento, estaria excluída a legitimidade do parquet para a propositura de demandas relativas a direitos individuais disponíveis ${ }^{271}$.

Após a entrada em vigor do Código de Defesa do Consumidor, a doutrina e a jurisprudência passaram a interpretar conjuntamente os incisos III e IX ${ }^{272}$ do artigo 129 da Constituição, justificando que o Ministério Público teria legitimidade para atuar na defesa dos interesses individuais homogêneos desde que a discussão envolvesse relevante

\footnotetext{
${ }^{270}$ O Ministério Público brasileiro foi dotado de uma série de garantias pela Constituição de 1988, alçando seus membros à mesma escala de importância dos magistrados, especialmente no que se refere ao arcabouço necessário para o exercício de suas funções de forma autônoma - tanto em relação ao poder Executivo quanto ao Judiciário. Essas características levaram o doutrinador italiano Mauro Cappelletti pontuar que "muito me alegra saber que tais razões de escasso êxito dessa solução na Europa não se aplicam ao Ministério Público brasileiro, sobretudo que sua independência foi assegurada pela Constituição, e em consequência também do fato de que algumas cidades do Brasil se criaram seções especializadas em matéria de interesses difusos, nos quadros do Ministério Público" (CAPPELLETTI, Mauro. O acesso dos consumidores à justiça. Revista de Processo, São Paulo, n. 62/208, abr./jun.1991, p. 53-63).

${ }^{271}$ GRINOVER, Ada Pellegrini; WATANABE, Kazuo; NERY JUNIOR, Nelson. Código Brasileiro de Defesa do Consumidor comentado pelos autores...Op. cit., p. 86.

${ }^{272}$ Artigo 129. São funções institucionais do Ministério Público: [...] IX. exercer outras funções que lhe forem conferidas, desde que compatíveis com sua finalidade, sendo-lhe vedada a representação judicial e a consultoria jurídica de entidades públicas.
} 
interesse social, compatível com a finalidade da instituição ${ }^{273}$. Essa posição se consolidou na jurisprudência pátria, tendo restado viva, apenas, a discussão acerca do que viria a ser “interesse social relevante".

Em princípio esse interesse era identificado nos julgados do Superior Tribunal de Justiça em temas reconhecidamente sociais, como os concernentes à educação (mensalidades escolares, por exemplo). Com o tempo, os mais diversos temas passaram a ser considerados como relevantes socialmente: desde a análise acerca da abusividade de cláusula em contratos de arrendamento mercantil, passando pelos direitos dos adquirentes de títulos de capitalização lesados pela atuação irregular da sociedade de capitalização no mercado financeiro, até a defesa de inquilinos contra imobiliárias que cobravam a chamada "Taxa Imobiliária"274.

Observou-se, portanto, uma ampliação considerável dos temas considerados de relevante interesse social, sendo que vários deles são notadamente interesses individuais disponíveis, que poderiam ser pleiteados por cada um dos interessados ou, mesmo, pelas associações de defesa cuja pertinência temática se enquadrasse à situação. A tendência ampliativa se fez sentir de forma tão marcante que já existem julgados do Superior Tribunal de Justiça admitindo que o simples fato de ser possível a tutela pela via coletiva já denota a relevância social do direito discutido ${ }^{275}$, o que, na prática, equivale a dizer que todos os direitos individuais homogêneos podem ser tutelados pelo Ministério Público.

Não se pretende diminuir os méritos do parquet na defesa dos interesses transindividuais de uma forma geral, reconhecendo-se que a atuação da entidade é de importância fundamental para o sistema de tutela dos direitos coletivos. Entretanto, a cultura paternalista característica da sociedade brasileira, aliada à ampliação desmedida da legitimidade para atuação do Ministério Público nas ações coletivas, pode acabar trazendo

\footnotetext{
${ }^{273}$ Orientação anotada no REsp n ${ }^{\circ}$ 168.859, de relatoria do Min. Ruy Rosado de Aguiar, publicado no Diário de Justiça de 22.08.1999. Ver, ainda, sobre o tema GRINOVER, Ada Pellegrini; WATANABE, Kazuo; NERY JUNIOR, Nelson. Código Brasileiro de Defesa do Consumidor comentado pelos autores...Op. cit., p. $86-87$.

${ }^{274}$ Nos comentários ao Código de Defesa do Consumidor, os autores do anteprojeto fazem referência a diversos julgados do Superior Tribunal de Justiça em que o Ministério Público foi considerado legítimo para a defesa dos interesses individuais homogêneos. Esses três temas citados, especificamente, estão nos Recursos Especiais $n^{\circ}$ 457.579/DF (julg. 10.02.2003); $n^{\circ} 311.492 / \mathrm{SP}$ (julg. 06.05.2002) e Embargos de Divergência em Recurso Especial no 114.908/SP (julg. 20.05.2002). Para os demais temas, ver GRINOVER, Ada Pellegrini; WATANABE, Kazuo; NERY JUNIOR, Nelson. Código Brasileiro de Defesa do Consumidor comentado pelos autores...Op. cit., p. 88.

${ }^{275}$ Ver Recurso Especial n ${ }^{\circ}$ 586.307/MT, $1^{\text {a }}$ Turma, Rel. Min. Luiz Fux, DJ 30.09.2004, p. 223 e Recurso

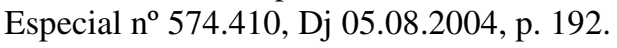


efeitos deletérios para o fortalecimento da sociedade civil enquanto responsável pela tutela dos seus próprios interesses.

E esse característico fortalecimento de entidades ligadas ao poder do Estado na tutela coletiva volta a se fazer notar quando da atribuição de legitimidade também à Defensoria Pública. Esta é um órgão público cuja criação foi pautada pela menção, no texto constitucional, à indispensabilidade do advogado para a administração da justiça (artigo 133 da Constituição Federal de 1988). Ora, assim é, e apenas em raras situações se dispensa a figura do advogado para que se acesse a justiça, sendo assim, cabe ao Estado garantir que aqueles que não tenham condições de contratar um advogado privado não sejam impedidos de acessar os tribunais brasileiros. Com essa finalidade foram criadas as Defensorias Públicas como "[...] instituição essencial à função jurisdicional do Estado, incumbindo-lhe a orientação jurídica e a defesa, em todos os graus, dos necessitados, na forma do art. 5, LXXIV"276 (artigo 134 da Constituição Federal de 1988).

No ano de $2007^{277}$, uma reforma legislativa incluiu na Lei da Ação Civil Pública a legitimidade ativa da Defensoria Pública para a propositura de ações visando a tutela dos direitos difusos, coletivos e individuais homogêneos. Essa atribuição suscitou, à época, diversas discussões a respeito da possibilidade dessa instituição atuar na defesa dos interesses transindividuais.

De um lado o Ministério Público contestou a legitimidade da Defensoria Pública por entender que haveria, por parte deste último órgão, usurpação de competência exclusiva do parquet para a propositura de demandas coletivas, competência esta atribuída pela Constituição Federal. Com base nisso, a CONAMP (Associação Nacional dos Membros do Ministério Público) ajuizou uma Ação Direta de Inconstitucionalidade ${ }^{278}$ contra a lei que atribui a legitimidade ativa à Defensoria Pública (Lei no 11.448/2007) ${ }^{279}$.

A referida Ação Direta de Inconstitucionalidade não foi julgada até o presente momento. A orientação maciça da doutrina e da jurisprudência, no entanto, moldou-se, nesse tocante, nos termos do parecer elaborado por Ada Pellegrini Grinover a pedido da Associação Nacional de Defensores Públicos ${ }^{280}$. Segundo a doutrinadora, a Constituição

\footnotetext{
${ }^{276}$ Art. $5^{\circ}$, inciso LXXIV - o Estado prestará assistência jurídica integral e gratuita aos que comprovarem insuficiência de recursos.

${ }^{277}$ Lei $11.448 / 2007$.

${ }^{278}$ Ação Direta de Inconstitucionalidade no 3943, Ministra Relatora Carmen Lúcia.

279 GRINOVER, Ada Pellegrini; WATANABE, Kazuo; NERY JUNIOR, Nelson. Código Brasileiro de Defesa do Consumidor comentado pelos autores... Op. cit., p. 90.

${ }^{280}$ Confira-se, a respeito, a opinião de Aluísio Gonçalves de Castro Mendes em "O anteprojeto de Código Brasileiro de Processos Coletivos e a Legitimidade da Defensoria Pública para Ações Coletivas” (MENDES,
} 
Federal não atribuiu ao Ministério Público competência exclusiva para a propositura de ações em defesa de direitos transindividuais, de modo que a legitimação da Defensoria Pública viria apenas acrescentar e ampliar o acesso à justiça. Destaca, ademais, que a legitimidade dessa entidade já vinha sendo admitida antes mesmo da positivação na Lei $\mathrm{n}^{\circ}$ 11.448/2007, por meio da interpretação conjunta do artigo 82, inciso III do Código de Defesa do Consumidor e do artigo 21 da Lei da Ação Civil Pública ${ }^{281}$.

Foi também levantado como possível óbice à legitimidade da Defensoria Pública o enquadramento funcional atribuído pela Constituição Federal à instituição, qual seja: a instrução jurídica e a defesa dos necessitados (artigo 134 da Constituição Federal de 88). O próprio artigo se ocupa de qualificar quem seriam os necessitados, remetendo à definição do artigo $5^{\circ}$, LXXIV do próprio texto constitucional, que fala especificamente em "insuficiência de recursos". O desafio era de compatibilizar a tutela dos interesses transindividuais - cuja titularidade nem sempre pode ser individualizada - com a finalidade institucional de auxiliar quem não tenha recursos suficientes para fazê-lo. Com relação a isso, cabe reproduzir brevemente a opinião de Ada Pellegrini Grinover que tratou da questão no parecer supracitado, esclarecendo que além de não existir no texto constitucional uma limitação às atribuições da Defensoria Pública - não havendo que se falar que a instituição atua exclusivamente na defesa de quem não tenha recursos para fazêlo - há, ainda, que se considerar que necessitados não são apenas aqueles que não tenham recursos financeiros para acessar a justiça:

\footnotetext{
Quando se pensa em assistência judiciária, logo se pensa na assistência aos necessitados, aos economicamente fracos, aos minus habentes. Este é, sem dúvida, o primeiro aspecto da assistência judiciária: o mais premente, talvez, mas não o único.

Isso porque existem os que são necessitados no plano econômico, mas também os necessitados do ponto de vista organizacional. Ou seja, todos aqueles que são socialmente vulneráveis: os consumidores, os usuários de serviços públicos, os
}

\footnotetext{
Aluisio Gonçalves de Castro Mendes. In: SOUZA, José Augusto Garcia (coord). A Defensoria Pública e os processos coletivos. Rio de Janeiro: Lumen Juris, 2008, p. 51; FERRARESI, Eurico. Ação popular, Ação Civil Pública e mandado de segurança coletivo. Rio de Janeiro: Forense, 2009, p. 205-210; e "A reiterada legitimidade da Defensoria Pública para o ajuizamento de ações coletivas”, MANCUSO, Rodolfo de Camargo; BEGA, Carolina Brambila. In: MILARÉ, Edis (coord). A Ação Civil Publica após 25 anos. São Paulo: RT, 2010, p. 733; entre outros.

${ }^{281}$ No mesmo parecer, Ada Pellegrini Grinover tece críticas severas à atitude dos integrantes do Ministério Público, chegando a afirmar que "[...] fica claro, assim, que o verdadeiro intuito da requerente, ao propor a presente ADIn, é simplesmente o de evitar a concorrência com a Defensoria Pública, como se no manejo de tão importante instrumento de acesso à justiça e de exercício da cidadania pudesse haver reserva de mercado”. Ver GRINOVER, Ada Pellegrini. Legitimidade da Defensoria Pública para Ação Civil Pública. Revista de Processo, São Paulo, v. 165, p.301, nov.2008.
} 
usuários de planos de saúde, os que queiram implementar ou contestar políticas públicas, como as atinentes à saúde, à moradia, ao saneamento básico, ao meio ambiente, etc.

[...] em razão da própria estruturação da sociedade de massa, uma nova categoria de hipossuficiente, ou seja, a dos carentes organizacionais, a que se referiu Mauro Cappelletti, ligada à questão da vulnerabilidade das pessoas em face das relações sociojurídicas existentes na sociedade contemporânea. [...]

Conforme bem observou Boaventura de Souza Santos, daí surge 'a necessidade de a Defensoria Pública, cada vez mais, desprender-se de um modelo marcadamente individualista de atuação ${ }^{282}$.

Desta forma, essa interpretação conferida ao conceito de "necessitados", visando ampliar o acesso à justiça, apazigua a discussão a respeito da defesa dos interesses difusos, coletivos e individuais homogêneos pela Defensoria Pública. Sob certo aspecto, dirime também a discussão quanto à necessidade de pertinência temática para essa finalidade - de defesa em juízo dos necessitados - e quanto ao objeto da ação proposta, uma vez que, tal qual acontece com a legitimidade do Ministério Público, sempre se poderá recorrer à caracterização do grupo defendido como "necessitados" do ponto de vista organizacional, dada a dispersão ou a relevância dos direitos defendidos.

Repita-se que se essa legitimação, por um lado, garante que o maior número possível de entidades possa ingressar em juízo para defender os direitos transindividuais, por outro é certo que prejudica o desenvolvimento de uma sociedade civil organizada capaz de, por seus próprios meios e iniciativas, se voltar ao resguardo de seus interesses. Tome-se como exemplo a tutela dos interesses dos consumidores. Estes contam com uma série de associações que podem levar os direitos ameaçados ou violados a juízo, de modo que não deveriam mais ser considerados carentes do ponto de vista organizacional. Ainda assim, não se cogita limitar a legitimidade da Defensoria Pública nessa matéria com base na suposta falta de pertinência temática.

A legitimação conferida aos integrantes da administração pública direta e indireta os entes políticos e as entidades a eles ligadas - tem um caráter ainda mais específico dentro do espectro da legitimidade para a propositura de ações coletivas. Sabe-se que esses entes estão limitados, no que tange à pertinência temática, pelas características da lide, pela natureza do bem jurídico tutelado, pela amplitude ou ameaça de lesão, pela quantidade e localização dos titulares dos interesses ameaçados, etc. Isso equivale a dizer que a União, ou determinado Estado ou Município, só terá legitimidade para propor uma ação

${ }^{282}$ Ibid., p. 302-303. Ver, ainda, "Acesso à justiça e o Código de Defesa do Consumidor” (GRINOVER, Ada Pellegrini. O Processo em evolução. Rio de Janeiro: Forense Universitária, 1996, p. 116-117); SOUZA SANTOS, Boaventura. Introdução à sociologia da administração da Justiça. Revista de Processo, São Paulo, n.37, p. 150 , jan/mar.1985. 
pretendendo a tutela dos interesses transindividuais se tais interesses guardarem algum nexo de pertinência com o seu âmbito de atuação. Em outras palavras, um determinado município não pode ingressar em juízo pretendendo a tutela de direitos de um grupo de potenciais beneficiários residentes em outro município ${ }^{283}$.

A rigor, o que se observa na atuação dos entes políticos e das entidades a eles ligadas é a defesa dos interesses de seus moradores - de seus contribuintes, seus eleitores em caráter coletivo. Assim, se os interesses guardam ligação com diversos municípios, qualquer um deles poderia ingressar com a ação coletiva. $\mathrm{O}$ mesmo ocorreria no âmbito dos Estados, restando à União a eventual tutela de interesses cuja dispersão atinja todo o país $^{284}$.

Conclui-se que, conquanto a legitimação autônoma e concorrente dos órgãos ligados ao poder estatal - no caso a Defensoria Pública, o Ministério Público e a Administração Pública - se dê no melhor interesse de ampliar o acesso à justiça, ela enseja uma concorrência em relação às iniciativas da sociedade civil, o que, em um país paternalista como o Brasil, tem efeitos deletérios na organização da sociedade para a defesa de seus próprios interesses - que é feito, em nossa legislação, pelas associações.

\subsubsection{Aspectos da legitimidade das associações para a propositura de ações em defesa dos interesses transindividuais segundo os critérios estabelecidos expressamente pela legislação pátria}

Os interesses transindividuais, conforme discutido em diversos pontos deste estudo, são aqueles em que seus titulares são grandes grupos da sociedade - cujos integrantes, por vezes, dada a dispersão dos direitos tratados, sequer podem ser individualizados. Assim, não é demais dizer que os direitos transindividuais são interesses da sociedade como um todo, ainda que em cada momento possam dizer respeito mais a um grupo que outro (direitos dos consumidores, dos investidores do mercado financeiro, ao Meio Ambiente preservado, ao patrimônio público, etc).

Por esse motivo, o reconhecimento da existência desses direitos e a configuração de um sistema processual para sua tutela jurisdicional preconizavam o surgimento de uma

\footnotetext{
${ }^{283}$ GRINOVER, Ada Pellegrini; WATANABE, Kazuo; NERY JUNIOR, Nelson. Código Brasileiro de Defesa do Consumidor comentado pelos autores...Op. cit., p. 94.

${ }^{284}$ Ibid., p. 94.
} 
consciência coletiva que permitisse à própria sociedade, por meio de representantes, defender os seus interesses ${ }^{285}$.

O que se observa, no entanto, após mais de 25 anos de vigência da Lei da Ação Civil Pública - que marcou o início de um microssistema de processo coletivo no Brasil -, é o predomínio das entidades ligadas ao poder público na propositura de ações em defesa dos direitos transindividuais ${ }^{286}$. Diversos fatores, que vão desde a mentalidade da sociedade brasileira até a carência de esforços legislativos no sentido de incentivar a organização da sociedade civil, contribuíram com essa realidade.

No que tange à falta de esforços legislativos, pode-se apontar a vedação à legitimação individual para a propositura de ações coletivas, que figurava no primeiro anteprojeto da Lei da Ação Civil Pública (Lei n ${ }^{\circ}$.347/1985) e foi extirpada no texto final aprovado. Isso se deu porque foi feita uma opção em termos de política legislativa, por haver um receio generalizado que as ações coletivas passassem a ser usadas como instrumentos de pressão e chantagem por parte de adversários políticos - como acontece, em muitos casos, com a ação popular, que contempla a legitimidade individual. Outro receio tangencia a discussão da representatividade adequada, uma vez que se ponderou a capacidade e a competência do legitimado individual para conduzir as ações coletivas, considerando fases complexas como a produção de provas $^{287}$. Preocupação que só faz sentido porque não existem regras expressas que autorizem o controle da representatividade adequada ou parâmetros definidos para tanto.

Desta forma, restaram como representantes da sociedade civil na defesa em juízo dos interesses coletivos apenas as associações civis. Estas, por serem a expressão da própria sociedade organizada em juízo, são consideradas por parte da doutrina como a mais importante forma de defesa dos direitos transindividuais. As associações são entes

\footnotetext{
${ }^{285}$ LENZA, Pedro. Teoria Geral da Ação Civil Pública...Op. cit., p. 194-195.

${ }^{286}$ Sobre o tema, manifestou-se o professor Kazuo Watanabe: "[...] a só existência de mecanismos processuais mais eficazes e mais ajustados à natureza dos conflitos a serem solvidos deverá fazer com que, juntamente com o conjunto de medidas antes enumeradas, a nova mentalidade tão almejada seja efetivamente uma realidade, fazendo com que, ao invés do paternalismo do Estado, tenhamos uma sociedade civil mais bem estruturada, mais consciente e mais participativa, enfim, uma sociedade em que os mecanismos informais e não oficiais de solução de conflitos de interesse sejam mais atuantes e eficazes do que os meios formais e oficiais". (GRINOVER, Ada Pellegrini; WATANABE, Kazuo; NERY JUNIOR, Nelson. Código Brasileiro de Defesa do Consumidor comentado pelos autores...Op. cit., p. 723).

${ }^{287}$ Ibid., p. 83-84.
} 
intermediários entre o cidadão e o Poder Público, e se prestam justamente a aumentar o poder de articulação dos primeiros na reivindicação de direitos perante os segundos ${ }^{288}$.

Assim, seja porque foram as únicas entidades que restaram no rol dos legitimados ativos para ações coletivas como efetivos representantes nascidos no seio da sociedade, seja porque têm um papel determinante no processo de organização e conscientização da sociedade civil, a atuação das associações em juízo tem importância central para a manutenção e desenvolvimento do microssistema dos direitos transindividuais e de sua tutela. Para tentar garantir que tal atuação se desse de forma séria e idônea, o legislador estabeleceu alguns critérios que devem ser observados pelos juízes para atribuir a legitimidade a essas entidades. Esses critérios são: (i) a constituição da associação há pelo menos um ano, a contar da data de propositura da ação e; (ii) a pertinência temática, expressa na coincidência entre os objetivos institucionais da associação e o assunto tratado na ação coletiva proposta ${ }^{289}$.

Como é possível observar, tais critérios primaram pela objetividade, uma vez que a breve análise dos estatutos da entidade associativa pelo juiz - aferindo-se a data de constituição da associação ${ }^{290}$, bem como o objetivo institucional declarado - em tese é capaz de preencher o requisito legal e verificar se ela é ou não legítima para propor a ação coletiva. Essa verificação do quanto é declarado pelas associações em seus estatutos é feita pelos juízes mas, não raro, aquilo que foi colocado no papel está dissociado da realidade, e não há norma expressa que impute ao magistrado o dever de verificar no caso concreto a atuação da associação na defesa dos direitos transindividuais, sua capacidade técnica ou sua idoneidade Em princípio, bastará verificar os termos expressos no estatuto social.

Ao prever que as associações deveriam comprovar o cumprimento de tais requisitos, quis o legislador estabelecer padrões mínimos para tentar garantir uma defesa realmente qualificada dos direitos coletivos pelas associações. Nesse tocante, a previsão da necessidade de se comprovar a pré-constituição há, pelo menos, um ano, pretendeu coibir

\footnotetext{
${ }^{288}$ Sobre o tema, ver VENTURI, Elton. Comentários ao Código Modelo de Processos Coletivos...Op. cit., p. 74-75 e FORNACIARI, Flávia Hellmeister Clito. Representatividade Adequada nos processos coletivos. 2010. 189 f. Dissertação sob orientação da professora Ada Pellegrini Grinover (Doutorado em Direito Processual Civil) Faculdade de Direito da Universidade de São Paulo, São Paulo, 2010, p. 81.

${ }^{289}$ Artigo 5, V, alíneas "a " e "b" e Artigo 82, IV do Código de Defesa do Consumidor.

${ }^{290}$ Como anteriormente discutido, há autores que consideram o registro em cartório como requisito de existência da associação e, com isso, tem-se a data inicial da contagem para o prazo de um ano referido nos artigos do Código de Defesa do Consumidor e da Lei da Ação Civil Pública. Este estudo, entretanto, filia-se à corrente que reconhece a existência e capacidade jurídica da associação desde o momento de sua constituição, de modo que a contagem do prazo em questão para associações não registradas passa a ser questão de prova - da data de constituição - cujo ônus cabe à associação autora. Vide capítulo 3, subitem 3.2.
} 
abusos que poderiam ser perpetrados por associações constituídas ad hoc para a propositura de toda a sorte de ações coletivas - algumas delas com motivação claramente política e/ou emulativa ${ }^{291}$. O que se pretende com essa aferição temporal, portanto, é verificar a seriedade da associação na defesa dos interesses metaindividuais. Esse requisito, entretanto, poderá ser dispensado pelo juiz caso esteja evidenciado manifesto interesse social - caso em que o magistrado deverá fazer uma análise in concreto, de acordo com as circunstâncias do caso, para dispensar ou não o requisito da pré-constituição ${ }^{292}$, uma vez que a aferição da seriedade seria suplantada pela necessidade de proteção imediata do direito tutelado.

Por outro lado, o requisito da pertinência temática tem como fundamento, primordialmente, a apuração da capacidade técnica da entidade associativa para defender determinados direitos em juízo. A base do dispositivo está na ideia de que a associação deve ser, de alguma forma, especializada em algum campo de atuação - o que possibilitaria uma defesa qualificada dos interesses de seus associados e, em alguns casos, de todos os integrantes de determinada coletividade ${ }^{293}$. Desta forma, pode-se afirmar que uma determinada associação deve se dedicar a um número determinado de matérias, justamente para que possa atuar com diligência e conhecimento na defesa - judicial e extrajudicial - dos direitos que decorrem de tais temas. Nessa esteira, hoje, no Brasil, há associações de defesa do consumidor, associações de defesa ao meio ambiente, associações de mutuários, dentre outras tantas.

Ademais, é possível dizer que dentro da lógica do microssistema dos processos coletivos, o critério da pertinência temática é fundamental para que se apure a legitimidade da associação, uma vez que - guardadas as devidas proporções em relação ao processo individual -, prestaria-se a configurar o liame entre o objeto do processo (direito material v.g. direito do consumidor) e o sujeito da relação jurídica processual (direito processual v.g. associação de defesa do consumidor), engendrado, como se viu, no próprio conceito de legitimidade ad causam. Em outras palavras, trata-se de comprovar a pertinência subjetiva

\footnotetext{
${ }^{291}$ GRINOVER, Ada Pellegrini; WATANABE, Kazuo; NERY JUNIOR, Nelson. Código Brasileiro de Defesa do Consumidor comentado pelos autores...Op. cit., p. 97.

${ }^{292}$ Art. $82, \S 1^{\circ}$, Código de Defesa do Consumidor. O requisito da pré-constituição pode ser dispensado pelo juiz, nas ações previstas nos arts. 91 e seguintes, quando haja manifesto interesse social evidenciado pela dimensão ou característica do dano, ou pela relevância do bem jurídico a ser protegido.

${ }^{293}$ COSTA, Susana Henriques da. Comentários à Lei de Ação Civil Pública e Lei de Ação Popular. São Paulo: Quartier Latin, 2006, p. 406-407.
} 
da ação ${ }^{294}$, entre o autor e o direito que ele pretende defender e, como não se pode falar em titularidade do direito discutido em juízo, também há que se comprovar ao menos a afinidade entre este último e os objetivos institucionais da associação autora.

Uma vez que esses requisitos foram listados como necessários apenas para que se atribuísse a legitimidade ativa às associações, parte da doutrina pátria considera que são eles a expressão legislativa da representatividade adequada passível de ser verificada pelo Poder Judiciário, além de representar o máximo que pode ser exigido de cautela pelo juiz $^{295}$. Essa parte da doutrina pode, ainda, se valer do fato de que, em alguma medida, os requisitos listados pela lei tentaram criar condições para se aferir a seriedade e a capacidade da entidade associativa.

Esse estudo, no entanto, demonstra, no capítulo 7, que a pré-constituição e a pertinência temática podem até nortear o juiz da causa na aferição da representatividade adequada - como se observa com certa frequência na jurisprudência ${ }^{296}$-, mas não podem, de forma alguma, constituir um limitador para a atividade jurisdicional. Até porque não se pode pretender criar um rol taxativo de elementos a serem verificados pelo juiz, já que tal análise deve se pautar na realidade - na atuação da associação -, que evolui muito mais rápido que a lei.

Nesse sentido, ressaltou Ada Pellegrini Grinover que diversos problemas podem ser observados na atuação das associações em defesa dos interesses transindividuais, uma vez que os requisitos legais não são suficientes para aferir a credibilidade, idoneidade, seriedade, capacidade econômica e técnica da entidade e de seus representantes. A real aferição dessas qualidades, indispensáveis para uma tutela eficaz dos direitos da coletividade em juízo, demandaria uma atuação mais profunda do juiz em cada caso concreto $^{297} \mathrm{e}^{298}$.

\footnotetext{
${ }^{294}$ Definição doutrinária de legitimidade ad causam de Alfredo Buzaid (BUZAID, Alfredo. Agravo de petição no sistema do Código de Processo Civil. 2. ed. São Paulo: Saraiva, 1956, p. 89).

${ }^{295}$ Filia-se à essa corrente Luiz Valery Álvaro Mirra, ao afirmar que "[...] esse requisitos, além de necessários, são suficientes para a caracterização da representatividade adequada da associação civil". Ver "Ação Civil Pública em defesa do meio ambiente: a representatividade adequada dos entes intermediários legitimados para a causa" (MIRRA, Álvaro Luiz Valery. In: MILARÉ, Edis (coord.). A ação civil pública após 20 anos: efetividade e desafios. São Paulo: RT, 2005, p. 46-47). Veja-se, ainda, a opinião de Ricardo de Barros Leonel: "Esses requisitos para a aferição da legitimidade das associações é que configuram a denominada representatividade adequada" (LEONEL, Ricardo de Barros. Manual do Processo Coletivo. 2.ed. São Paulo: RT, 2011, p. 162). No mesmo sentido, ZAVASCKI, Teori Albino. Processo Coletivo tutela de direitos coletivos e tutela coletiva de direitos. São Paulo: Editora RT, 2006.

${ }^{296}$ Vide capítulo 7, em que se analisa a aferição da representatividade adequada pelos Tribunais brasileiros.

${ }^{297}$ GRINOVER, Ada Pellegrini. Ações Coletivas ibero-americanas: novas questões sobre a legitimação e a coisa julgada. Revista Forense. Rio de Janeiro: Forense, vol. 361, 2002, p. 3-12.
} 
Assim, é certo que os requisitos apontados pelo legislador são importantes para pautar e delinear a atuação do juiz na aferição da representatividade adequada. Entretanto, o conceito de representatividade adequada é muito mais amplo, profundo e, por que não dizer, está em constante evolução, sendo sua verificação incompatível com um rol taxativo de requisitos. Nas precisas palavras de José Marcelo de Menezes Vigliar:

[...] a representação adequada é condição que se conquista. Essa conquista surge de atividade diuturna. Essa qualidade não pode decorrer do que está escrito num 'contrato' de formação de uma pessoa jurídica de direito privado. Concordo que essas exigências devam ser mantidas. Mas devem ser as mínimas. Mais que esses requisitos, devem-se conceder ao juiz do caso concreto a análise do efetivo compromisso que guarda com a causa (seja a do consumidor, seja a do meio ambiente etc. $)^{299}$.

É justamente do conceito de representatividade adequada e de sua função estrutural nas ações que se prestam à tutela dos interesses transindividuais, desde sua gênese no sistema de common law até o presente, que se tratará no capítulo seguinte. Com isso, restará delimitada a base conceitual deste estudo, para que se possa identificar se, e de que forma, o ordenamento jurídico brasileiro permite o controle judicial da representatividade adequada das associações.

\footnotetext{
298 FERRARESI, Eurico. Ação popular, ação civil pública e mandado de segurança coletivo: instrumento processuais coletivos. Rio de Janeiro: Forense, 2009, p. 118.

${ }^{299}$ Ver "Defendant class action brasileira: limites propostos para o "Código de Processos Coletivos"" (VIGLIAR, José Marcelo de Menezes. In: GRINOVER, Ada Pellegrini et alli (coord.). Direito processual coletivo e anteprojeto de Código Brasileiro de Processos Coletivos. São Paulo: RE, 2007, p. 319.
} 


\section{REPRESENTATIVIDADE ADEQUADA NAS AÇÕES COLETIVAS}

Fixado o conceito de associação, sua natureza jurídica e os elementos básicos para serem consideradas verdadeiras associações, fez-se uma incursão na evolução da legitimidade ativa para a propositura de ações coletivas no Brasil, verificando de que forma esse conceito foi se adaptando para permitir a defesa por essas entidades dos direitos transindividuais. Cabe, agora, adentrar a matéria da representatividade adequada e dos critérios a serem observados para sua aferição e discutir se, no atual cenário legislativo brasileiro, é possível que os magistrados façam esse escrutínio.

Para criar as bases da discussão sobre a possibilidade de verificação ope judicis dos requisitos da representatividade adequada, será feita uma incursão no tema pela análise do conceito, dissecando sua natureza jurídica e a forma como a doutrina pátria a classifica no âmbito do microssistema de processos coletivos. Tal análise passará, ainda, pelo estudo da gênese do instituto no direito inglês e seu desenvolvimento no direito norte-americano, em que ganhou contornos mais definidos.

Por fim, tratar-se-á da representatividade adequada em outros ordenamentos jurídicos, tanto de Common Law quanto de Civil Law, buscando entender de que forma esse conceito tem sido encampado nos diversos países em que a defesa dos interesses transindividuais se faz presente. Com isso, será possível estudar as tentativas de positivação do instituto no ordenamento jurídico brasileiro que, até o presente momento, não lograram êxito em incluir a necessidade da aferição da representatividade adequada pelos juízes em nossa legislação.

\subsection{DISCUSSÕES SOBRE O CONCEITO E A NATUREZA JURÍdICA DA REPRESENTATIVIDADE ADEQUADA NO ORDENAMENTO JURÍDICO BRASILEIRO}

\subsubsection{Evolução do conceito}

A representatividade adequada é um instituto característico e exclusivo dos processos coletivos, inexistente no processo civil clássico - guiado precipuamente pela perspectiva individualista - e, por esse motivo, é um dos pontosque diferencia a sistemática processual que se volta à defesa dos interesses transindividuais e justifica o seu 
estudo de forma autônoma e específica ${ }^{300}$. Sua gênese está ligada à necessidade de assegurar que as garantias constitucionais do processo justo - notadamente o pleno e efetivo contraditório e a ampla defesa ${ }^{301}$ - sejam resguardadas integralmente, mesmo nos processos em que aqueles que serão atingidos pelos efeitos da coisa julgada não integrem a relação jurídica processual e, portanto, não possam exercer diretamente os direitos atinentes a essa posição jurídica.

É possível dizer que o conceito de representatividade adequada, conquanto possa ser analisado por grande parte da doutrina apenas como parcela integrante do conceito de legitimidade ${ }^{302}$ - como um dos elementos a ser aferido para a atribuição da legitimidade de determinado ente ou pessoa que pretenda defender os interesses de terceiros em ações coletivas - tem características próprias que extrapolam os limites da legitimidade ativa ou passiva no âmbito processual e ganham contornos de direito material, além de estarem ligadas à ideia de legitimação. Por esse motivo, justifica-se a conceituação e o estudo desse instituto de forma autônoma e independente em relação ao instituto da legitimidade processual, reconhecendo, entretanto, a intrínseca vinculação entre os dois ${ }^{303}$.

Conceituar e delimitar o instituto da representatividade adequada constituem-se em tarefas árduas, que têm sido empreendidas pela doutrina e jurisprudência dos mais diferentes países ao longo das últimas três décadas. Isso acabou gerando uma multiplicidade de expressões, entre as quais se destacam algumas lançadas pelos estudiosos do tema no direito brasileiro para tentar conceituar a representatividade adequada: "efetivo compromisso entre aquele que pretende realizar a defesa e o direito transindividual que

\footnotetext{
${ }^{300}$ Nesse sentido, pontua Ada Pellegrini Grinover: "Esse instituto, desconhecido do processo individual, alicerça no processo coletivo a legitimação, exigindo que o portador em juízo dos interesses ou direitos difusos e individuais homogêneos apresente as necessárias condições de seriedade e idoneidade, até porque o legitimado é o sujeito do contraditório, do qual não participam diretamente os membros do grupo, categoria ou classe de pessoas. No Código Modelo, a representatividade adequada constitui requisito autônomo para o exercício da ação, a ser aferido pelo juiz em cada caso concreto", Ver "Direito Processual Coletivo" (GRINOVER, Ada Pellegrini. In: LUCON, Paulo Henrique dos Santos (coord.). Tutela Coletiva: 20 anos da Lei da Ação Civil Pública e do Fundo de Defesa dos Direitos Difusos, 15 anos do Código de Defesa do Consumidor. São Paulo: Ed. Atlas, 2006, p. 303.

${ }^{301}$ Ver, nesse sentido, COMOGLIO, Luigi Paolo. Etica e Tecnica del "Giusto Processo". Torino: G. Giappichelli Editore, 2004, p. 39-93.

302 Mais adiante, quando da discussão acerca da natureza jurídica da representatividade adequada, tais posições serão debatidas.

303 Até porque, conforme ressalta Flávia Hellmeister Clito Fornaciari, o instituto da representatividade adequada está ligado a mais de um tema no âmbito do processo coletivo - sua aferição refletirá não apenas na atribuição de legitimidade a determinado sujeito ativo, como também terá implicações nos limites subjetivos da coisa julgada nas ações que visam a proteção dos interesses metaindividuais. Ver FORNACIARI, Flávia Hellmeister Clito. Representatividade Adequada nos processos coletivos...Op cit., p. 48.
} 
será defendido" "304; "especial qualidade do autor da ação coletiva"305; "conjunto de fatores que indicará que o autor da ação coletiva irá despender eficazmente todos os esforços necessários para a defesa dos interesses das pessoas ausentes no processo"306e307. Parece, entretanto, que essas definições se atêm à análise da representatividade adequada enquanto parte integrante da legitimidade processual e, portanto, adstrita à existência de um processo.

Aqui se pretende desenvolver o raciocínio no qual a representatividade adequada, para ser compreendida de forma global, pode ser definida e conceituada sob dois prismas o extraprocessual (ou pré-processual) e o endoprocessual ${ }^{308}$-, o que pode ser feito por meio da dissecção do termo, bem como por uma análise do que se entende, em primeiro plano, por "representante" da coletividade e, em um segundo momento, de que elementos ela precisa estar dotada para ser considerada “adequada”. Desta forma, será possível conformar uma análise mais minuciosa do instituto como um todo, buscando uma conceituação que preencha, tanto quanto for possível, a subjetividade de que vem carregada a expressão "representatividade adequada".

Desde logo é preciso ter em mente que o representante, no contexto da representatividade adequada, não se identifica com a figura clássica descrita pelos institutos da representação ou do exercício de mandato, como preconizado pela dogmática civilista $^{309}$, pois não há uma atribuição ou delegação formal de poderes para que o representante atue no interesse dos componentes da classe representada. É o que assevera Antônio Gidi, que usou a expressão "porta-voz" para definir o representante da classe, defendendo que a interpretação semântica, e não jurídica, do termo não acarreta perdas para o sistema jurídico brasileiro, devendo ser mantida a tradução da expressão norte-

\footnotetext{
${ }^{304}$ Ver "Interesses difusos, coletivos e individuais homogêneos". VIGLIAR, José Marcelo Menezes. In: DIDIER, Fredie (coord.). Estudos em Homenagem a Eduardo Espínola, Coleção temas de processo civil. volIII. Salvador: Ed. Jus Podium, 2006, p.23.

${ }^{305}$ GRINOVER, Ada Pellegrini. Direito Processual Coletivo...Op.cit., p. 304.

${ }^{306}$ DINAMARCO, Pedro Silva. Ação Civil Pública....Op cit., p. 202.

${ }^{307}$ PASCHOAL, Maximilian Fierro. A representatividade adequada na ação coletiva brasileira (lei da ação civil pública e código de defesa do consumidor)...Op. cit., p. 106-109.

${ }^{308}$ FORNACIARI, Flávia Hellmeister Clito. Representatividade Adequada nos processos coletivos...Op. cit., p. 49-50.

${ }^{309}$ A representação, no Código Civil, está definida pelos artigos 115 a 120, enquanto a figura do mandato, bem como as obrigações e direitos do mandatário, encontram-se nos artigos 653 a 666 do mesmo diploma legal.
} 
americana - adequacy of representation - onde o instituto se desenvolveu e se firmou como um dos pilares do processo coletivo ${ }^{310}$.

O representante é, portanto, aquele que tem poder para falar em nome de todos os integrantes de determinada classe ou grupo quando assim se faça necessário ${ }^{311}$. Aquele que fala em nome de todos, e que atua como intérprete das pretensões do grupo, espera-se que tenha maior conhecimento - fático e, dependendo da situação, técnico - acerca dos assuntos de interesse da coletividade representada. Para ilustrar essa premissa, uma associação que pretenda defender os interesses do consumidor, presume-se que tenha maior conhecimento da legislação que protege os direitos dessa classe de pessoas, dos mecanismos atinentes a essa defesa, que o cidadão comum.

Uma entidade somente poderá ser tida como representante de uma coletividade quando existir uma comunhão de interesses entre ela e aqueles que são por ela representados $^{312}$. Somente no espectro em que os interesses da classe e do representante são iguais é que se poderá verificar a representatividade. Em outras palavras, uma associação pode ter interesses próprios que não concernem à classe que se propôs a defender (e.g. pleitear a isenção de impostos enquanto entidade sem fins lucrativos), e interesses que compartilha com a coletividade que lhe tem como porta-voz. Apenas neste último caso é que a associação poderá ser tida como representante da classe - em juízo ou fora dele.

Em última análise, pode-se afirmar que a figura do representante da classe existe antes - e independentemente - da existência do ajuizamento de uma demanda coletiva ou de um pleito extrajudicial em que este defenda os interesses de uma determinada coletividade. Nesse sentido Owen Fiss define a existência de grupos e - via de consequencia - de seus representantes, como um fenômeno de ordem social, independente da existência de ações judiciais ou construções legais que assim os caracterize ${ }^{313}$.

\footnotetext{
${ }^{310}$ GIDI, Antonio. A Class Action como instrumento de tutela coletiva dos direitos - as ações coletivas em uma perspectiva comparada. São Paulo: Ed. RT, 2007, p. 99-101.

${ }^{311}$ Ver "Tutela constitucional dos interesses coletivos ou difusos". BARBOSA MOREIRA, José Carlos. Temas de direito processual. $3^{\text {a }}$ série. São Paulo: Saraiva, 1984, p. 203. Ver, também, FORNACIARI, Flávia Hellmeister Clito. Representatividade Adequada nos processos coletivos...Op cit., p. 48.

${ }^{312}$ FORNACIARI, Flávia Hellmeister Clito. Representatividade Adequada nos processos coletivos... $O p$. cit., p. 50.

${ }^{313}$ Nas palavras de Owen Fiss " $[$...] o grupo existe, tem uma identidade, pode ser prejudicado, mesmo que os indivíduos ainda não o estejam sendo e que cada membro individualmente considerando não esteja ameaçado pela organização" (FISS, Owen. Um novo processo civil. São Paulo: Ed. RT, 2004, p. 51-52. No mesmo sentido, Flavia Hellmeister Clito Fornaciari, interpretando o texto do autor supracitado, diz " $[$...] existindo o grupo, existirá também seu representante adequado, independente da judicialização de qualquer conflito"
} 
Assim, partindo dessa conformação do conceito de representante - enquanto indivíduo ou entidade que guarda, a um só tempo, identidade com os integrantes da classe representada e com os interesses que pretende representar -, é possível passar à análise da adequação do representante, esta sim dependente e ligada à defesa dos direitos da classe em um processo judicial ou procedimento extrajudicial.

Enquanto a "representatividade" pode ser vista como um conjunto de características intrinsecamente ligadas à existência do grupo e de interesses comuns que, eventualmente, poderão ser defendidos pela figura do representante - portanto, independente da judicialização de um conflito -, a "adequação", por outro lado, é um conceito que depende de um juízo de valor externo para que seu significado seja preenchido ${ }^{314}$. Esse juízo de valor pode ser delineado pela lei, que poderá estabelecer critérios para a sua realização, mas será feito, efetivamente, pelo juiz da causa (ou por aquele a quem couber a decisão, no caso de defesa extrajudicial dos interesses da classe).

Atualmente observam-se algumas tendências, em diferentes ordenamentos jurídicos, quanto à presença da representatividade adequada e da possibilidade de aferição dos requisitos a ela ligados: (i) positivação da possibilidade de aferição da representatividade adequada e dos requisitos mínimos a serem observados pelo juiz ao fazê-lo; (ii) positivação da necessidade de se aferir a representatividade adequada, deixando a cargo da jurisprudência o preenchimento dos contornos dessa aferição; e (iii) ausência de menção expressa na lei à necessidade ou possibilidade de verificação pelo juiz da adequação de determinado representante.

Exemplo da primeira tendência é o Código Modelo de Processos Coletivos para a Ibero-América, que atribui ao juiz a tarefa de analisar dados como credibilidade,

(FORNACIARI, Flávia Hellmeister Clito. Representatividade Adequada nos processos coletivos...Op. Cit., p. 51).

314 Posição análoga é defendida por Flávia Hellmeister Clito Fornaciari: “Obviamente, antes de uma perquirição administrativa ou judicial dos direitos passíveis de tutela, a adequação do representante permanece velada, pois seus atos não terão, a princípio, efeitos vinculantes aos "representados". Todavia, a partir do momento em que o representante busca, nas esferas administrativa ou judicial, impedir a violação dos direitos, reparar uma afronta já ocorrente ou defender o grupo em face de eventuais direitos antagônicos de outras pessoas ou grupos, sua atuação deverá ser fiscalizada, para evitar que seus atos prejudiquem os diretamente interessados" (FORNACIARI, Flávia Hellmeister Clito. Representatividade Adequada nos processos coletivos...Op. cit., p. 51). No mesmo sentido, é possível interpretar a posição de Ada Pellegrini Grinover, ao destacar que "[... ] seria de grande valia reconhecer ao juiz o controle sobre a legitimação, em cada caso concreto, de modo a possibilitar a inadmissibilidade da ação coletiva, quando a "representatividade" do legitimado se demonstrasse inadequada" (Ver "Novas questões sobre a legitimação e a coisa julgada nas ações coletivas". GRINOVER, Ada Pellegrini. O processo - estudos e pareceres. 2. ed. São Paulo: Ed. DPJ, 2002, p.267). 
capacidade, prestígio, experiência do legitimado, seu histórico na proteção judicial e extrajudicial dos interesses ou direitos dos membros do grupo, categoria ou classe, entre outros $^{315}$. A segunda corrente pode ser exemplificada pelo ordenamento norte-americano que simplesmente se remete à necessidade de que o representante defenda adequadamente os interesses da classe representada, legando à jurisprudência a tarefa de preencher os contornos do que seria considerado "adequado",316. A terceira vertente, como algumas vezes já se teve a oportunidade de mencionar neste estudo, pode ser representada pela nossa legislação, que não faz menção expressa à necessidade ou à possibilidade de se aferir a representatividade adequada dos legitimados à propositura de ações coletivas.

Entretanto, mesmo nos casos em que é positivada a aferição da representatividade adequada, a lei somente estabelece parâmetros para sua verificação, já que o juízo de valor que preencherá o âmbito de significação do conceito de "adequação" deverá ser feito, em qualquer situação, pelo julgador, levando em conta as especificidades do caso concreto. Por esse motivo seria impossível arrolar taxativamente os caracteres que virão a compor tal conceito em todas as situações em que ele poderá ser verificado ${ }^{317}$.

Quanto aos ordenamentos jurídicos que nada mencionam sobre a representatividade adequada - ou sobre a possibilidade de sua aferição pelo juiz quando da atribuição de legitimidade à parte -, como ocorre no Brasil, há intensa discussão na doutrina a respeito da possibilidade desse escrutínio ser realizado pelo juiz - especialmente ante a inexistência de parâmetros legais.

\footnotetext{
315 Artigo $2^{\circ}$, II, $\S 2^{\circ}$ do Código Modelo de Processos Coletivos para Ibero-América: Na análise da representatividade adequada o juiz deverá analisar dados como: a - credibilidade, capacidade, prestígio, experiência do legitimado; $b$ - seu histórico na proteção judicial e extrajudicial dos interesses ou direitos dos membros do grupo, categoria ou classe; $\mathrm{c}$ - sua conduta em outros processos coletivos; $\mathrm{d}$ - sua capacidade financeira para a condução do processo coletivo; e - a coincidência entre os interesses do grupo, categoria ou classe e o objeto da demanda; $\mathrm{f}$ - o tempo de instituição da associação e a representatividade desta ou da pessoa física perante o grupo, categoria ou classe.

${ }^{316}$ Redação da quarta "consideração prévia" exigida para a instauração regular de uma Class Action, constante da Regra 23 do Código Federal de Processo Civil Norte-Americano (Federal Rule of Civil Procedure), conferida pela reforma de 1966 ["(4) the representative parties will fairly and adequately protect the interests of the class."].

${ }^{317}$ Especificamente no que se refere aos critérios que devem ser observados para aferição da adequacy of representation no direito norte-americano, Antonio Gidi aponta três requisitos que devem ser apurados pelo juiz na fase de certificação da Class Action, quais sejam: (i) vigorosa tutela pelo representante; (ii) ausência de conflito entre os interesses do representante e do grupo; (iii) vigorosa tutela e ausência de conflitos também por parte do advogado do grupo (GIDI, Antonio. A Class Action como instrumento de tutela coletiva dos direitos, as ações coletivas em uma perspectiva comparada. São Paulo: Ed. RT, 2007, p. 99124). Sobre o caráter exemplificativo do rol de requisitos para a verificação da representatividade adequada, ver "La representation adequada em las acciones Colectivas Brasileñas y el avance del Codigo Modelo" (GIDI, Antonio; MAC-GREGOR, Eduardo Ferrer (coords.). La tutela de los derechos difusos, colectivos e individuales homogeneos: hacia um Codigo Modelo para Iberoamerica. Cidade do México: Ed. Pórrua, 2004, p.153).
} 
Nos ordenamentos em que estão positivados tanto a necessidade quanto os parâmetros mínimos para que o juiz realize a aferição da representatividade adequada há uma margem menor de liberdade para os juízes, criando uma aparente convergência entre a vontade do legislador e a atuação jurisdicional. Entretanto, mesmo nos ordenamentos jurídicos em que apenas a necessidade de aferição foi positivada ou naqueles em que nada foi dito, não é possível descartar a atuação dos juízes, por ser a verificação do requisito uma consequência da garantia do devido processo legal nos processos coletivos, como adiante se verá.

Entende-se, assim, que o conceito de representatividade adequada deve ser analisado em dois momentos para ser compreendido integralmente - o momento préprocessual, em que se verifica a condição do representante, e o momento endoprocessual, em que se faz a aferição da adequação deste representante. O representante adequado é, portanto, aquele que tem uma relação com o grupo representado e com os interesses que representará em nome desse grupo; e uma vez que seja instado a fazê-lo - em juízo ou fora dele -, que o faça de forma séria, idônea, vigorosa, técnica e capaz ${ }^{318}$.

\subsubsection{Natureza Jurídica}

Para além da delimitação do conceito de representatividade adequada, entretanto, cabe analisar a natureza jurídica dessa representatividade no contexto da tutela dos interesses transindividuais, verificando se poderia ser classificada como pressuposto processual ou condição da ação - e, se entendida como condição da ação, se seria integrante da legitimidade ou do interesse de agir.

Os pressupostos processuais, expressão cunhada pelo doutrinador alemão Oskar von Bülow e hoje adotada amplamente pela doutrina brasileira, nascem do reconhecimento do processo enquanto relação jurídica distinta daquela que deu origem ao seu objeto - no momento em que a relação jurídica processual passa a ser vista de forma autônoma, não totalmente análoga à relação jurídica de direito material, embora esteja com ela intrinsecamente relacionada $^{319}$. São, assim, as condições mínimas para que o processo seja

\footnotetext{
${ }^{318}$ Para usar os termos que aparecem com maior frequência nos textos doutrinários e, ainda, nos projetos e anteprojetos de lei que procuram arrolar características que os representantes devem apresentar para que sejam considerados adequados.

${ }^{319} \mathrm{Na}$ definição de Oskar von Bülow, os "pressupostos processuais" (prozessuale voraussetzungen) são os requisitos para a admissibilidade (die erfordenisse für die zulässigkeit), as condições prévias para a formação definitiva de toda relação processual (die vorbedingungen für zustandekommen des ganzen
} 
instaurado e se desenvolva regularmente, referindo-se primordialmente aos aspectos formais dessa nova relação jurídica - os elementos que condicionam a sua existência, os requisitos para sua validade e os fatores para sua eficácia ${ }^{320}$.

Partindo dessas considerações iniciais, na sistemática do direito norte-americano, a representatividade adequada é elemento essencial e indispensável para que uma determinada ação seja recebida e processada como Class Action (requisito de certificação) - sendo, naquele sistema, um pressuposto processual desse tipo de demanda ${ }^{321}$. Ao analisar a questão com base no ordenamento jurídico brasileiro, no entanto, a doutrina pátria manifesta opiniões divergentes.

Entre os estudiosos que defendem que a representatividade adequada seria pressuposto processual dentro do microssistema brasileiro de tutela dos interesses coletivos estão alguns nomes como, por exemplo, Hugo Nigro Mazzilli, que baseia sua posição no que entende serem os requisitos para a aferição da adequação do representante positivados em nossa legislação - quais sejam: a constituição das associações há, pelo menos, um ano e a pertinência temática entre tais entidades e o direito defendido em juízo (artigos $82^{\circ}$, IV do Código de Defesa do Consumidor e 5, V, "a" e "b" da Lei da Ação Civil Pública) $)^{322}$. O

prozessverhältiness), a condição de existência da relação processual, os requisitos para a válida formação definitiva da relação processual (BÜLOW, Oskar von. La teoria de las excepciones procesales y los prespuestos procesales. Traduzido por Miguel Angel Rosas Lichtschein. Buenos Aires: EJEA, 1964, p. 8.

${ }^{320}$ Ver "Sobre pressupostos processuais" (MOREIRA, José Carlos Barbosa. Temas de direito processual civil. $4^{\text {a }}$ série. São Paulo: Editora Saraiva, 1989, p. 84. Ver, também, DIDIER JR., Fredie. Pressupostos processuais e condições da ação...Op. cit., p. 101. Esses doutrinadores se ocupam de esclarecer que não há consenso quanto àquilo que seria possível classificar como pressuposto processual, alertando que se tem colocado sob essa categoria um sem número de requisitos, o que leva Barbosa Moreira a pontuar que "[...] quando se diz, porém, que determinado requisito é pressuposto processual, a rigor é pouquíssimo o que se fica sabendo a seu respeito" (BARBOSA MOREIRA, José Carlos. Sobre pressupostos processuais...Op. cit., p. 93).

${ }^{321}$ Partindo da definição de pressuposto processual, a relação processual só se formará definitivamente em relação à toda a classe - nas Class Actions - uma vez verificada e chancelada a representatividade adequada pelo juiz, pelo que entende-se tratar de pressuposto processual. É o que assevera Lorenzo Bujosa Vadell ao dizer que "[...] el presupuesto processal que, em terminologia de Derecho estodounidense recibe el nombre de adequacy of representation, se fundamenta em la aplicación a situaciones nuevas de caráter y relevância colectiva soluciones referidas a situaciones individualistas de contenido essencialmente patrimonialista" (tradução livre: esse pressuposto processual, que recebe, na terminologia norte-americana, o nome de representatividade adequada, fundamenta-se na aplicação a situações novas de caráter e relevância coletivos de soluções referidas em situações individuais e de conteúdo essencialmente patrimonial.). (VADELL, Lorenzo Bujosa. La Proteccion Jurisdiccional de los interesses de Grupo. Barcelona: José M. A. Bosch Editor S.A, 1995, p. 186). Ver, também TUCCI, Luiz Rogério Cruz e. “Class Action” e mandado de segurança coletivo: diversificações conceptuais. São Paulo: Saraiva, 1990, p. 20-21.

${ }^{322}$ Textualmente, assinala Hugo Nigro Mazzili que “[...] os requisitos de representatividade adequada e pertinência temática são pressupostos processuais, não condições da ação (legitimidade de parte, interesse processual e possibilidade jurídica do pedido)". Ilustrando sua posição, diz: "Uma associação pode estar constituída há menos de um ano e ter interesse processual (o juiz pode dispensar o pressuposto processual da pré-constituição, mas não pode dispensar uma condição da ação), ou ao contrário, pode ter finalidade 
professor José Rogério Cruz e Tucci não se manifesta especificamente acerca do instituto no ordenamento jurídico brasileiro, mas classifica a adequacy of representation do direito norte-americano como pressuposto processual ${ }^{323}$.

Por outro lado, a maior parte da doutrina brasileira entende que a representatividade adequada integra o rol das condições da ação, reconhecendo que os fatores que a compõe estariam associados à atribuição aos autores de legitimidade ativa para a defesa dos interesses transindividuais ${ }^{324}$.

Como tratado no capítulo anterior, as condições da ação são requisitos, verificados a partir da relação jurídica de direito material, que devem ser preenchidos para possibilitar o julgamento do mérito da causa ${ }^{325}$. José Roberto dos Santos Bedaque assinala que, muito embora sejam as condições da ação exigências previstas pela técnica processual para a admissibilidade do processo, elas são verificadas com vistas à pretensão deduzida pelo autor $^{326}$ - ao contrário dos pressupostos processuais que se referem, primordialmente, ao controle da regularidade formal do processo.

Assim, aplicando tais premissas à representatividade adequada, este estudo se alinha à corrente que classifica o instituto como condição da ação, uma vez que, como bem ressaltado por Maximiliano Fierro Paschoal, não parece ser necessário classificar a verificação da adequação do representante da classe nas demandas coletivas como mero requisito formal, dissociado da relação de direito material objeto do processo ${ }^{327}$. Essa orientação se coaduna com o conceito de representatividade adequada delineado no item anterior, que parte justamente da relação entre o representante e o objeto da demanda.

Entretanto, é necessário ter em vista que a representatividade adequada, por não estar prevista expressamente entre os requisitos de admissibilidade das ações coletivas em

institucional para defender o meio ambiente e pode estar constituída há vários anos, mas, em concreto, não ter interesse processual" (MAZZILI, Hugo Nigro. A defesa dos interesses difusos em juízo: meio ambiente, consumidor, patrimônio cultural, patrimônio público e outros interesses. São Paulo: Saraiva, 2002, p. 281-282).

${ }^{323}$ TUCCI, Luiz Rogério Cruz e. “Class Action” e mandado de segurança coletivo...Op. cit., p. $20-21$.

${ }^{324}$ Anote-se a orientação divergente de que seria a representatividade adequada relacionada ao interesse de agir, manifestada pelo professor e ministro do Superior Tribunal de Justiça, Teori Albino Zavascki, ao considerar que a vinculação entre o objeto da demanda e a finalidade institucional do demandante é exigência associada ao interesse de agir. Ver, ZAVASCKI, Teori Albino. Processo Coletivo - tutela de direitos coletivos e tutela coletiva de direitos. São Paulo: Editora RT, 2006, p. 174.

${ }^{325}$ DIDIER JR., Fredie. Pressupostos processuais e condições da ação...Op cit., p. 207.

326 BEDAQUE, José Roberto dos Santos. Efetividade do processo e técnica processual. São Paulo: Malheiros, 2006, p. 237.

${ }^{327}$ PASCHOAL, Maximilian Fierro. A representatividade adequada na ação coletiva brasileira....Op. cit., p. 113. 
nosso ordenamento jurídico, não é propriamente uma condição da ação, mas sim um componente de uma das condições da ação - no caso, da legitimidade ad causam. Ou, nas palavras de Ada Pellegrini Grinover, a representatividade adequada é um dos alicerces da legitimidade, estando de tal forma relacionadas que uma não existe sem a outra ${ }^{328}$.

A identidade entre representatividade adequada e legitimidade ad causam não é completa porque os requisitos estabelecidos pela legislação brasileira para atribuição da legitimidade extraordinária para a propositura de demandas coletivas não se confundem com a representatividade adequada ${ }^{329}$, muito embora a doutrina extraia da existência desses requisitos e da possibilidade do juiz flexibilizar a sua aplicação, com base no texto do artigo $82, \S 1^{\circ}$ do Código de Defesa do Consumidor, uma predisposição da legislação e da jurisprudência brasileira a admitir a aferição da representatividade adequada dos legitimados ${ }^{330}$.

Essa posição é reforçada pelo fato do legislador ter feito um extenso rol de legitimados ativos extraordinários para a propositura de ações coletivas sem ter se preocupado em estabelecer parâmetros para a verificação de sua representatividade adequada - o que, de forma alguma, deve ser interpretado como uma presunção de que tais entidades sejam sempre representantes adequadas dos interesses da coletividade ${ }^{331}$.

Nas palavras de Fredie Didier Junior e Hermes Zaneti Junior, a atribuição de legitimidade e a verificação da representatividade adequada se dão em dois momentos diversos:

\begin{abstract}
Primeiramente, verifica-se se há autorização legal para que determinado ente possa substituir os titulares coletivos do direito afirmado e conduzir o processo coletivo. A seguir, o juiz faz o controle in concreto da adequação da legitimidade para aferir, sempre motivadamente se estão presentes os elementos que asseguram a representatividade adeuqada dos direitos em tela ${ }^{332}$.
\end{abstract}

A aferição da representatividade adequada, enquanto componente da legitimidade, portanto, não está expressa em nosso ordenamento jurídico. Contudo, deve-se ressaltar, é amplamente reconhecido pela doutrina que somente os requisitos formais para a atribuição

\footnotetext{
${ }^{328}$ Ibid., p. 123.

${ }^{329}$ Nesse sentido, DINAMARCO, Pedro da Silva. A ação civil pública...Op. cit., p. 112.

${ }^{330}$ Ver "Novas questões sobre a legitimação e a coisa julgada nas ações coletivas" (GRINOVER, Ada Pellegrini. O Processo, estudos e pareceres. 2.ed. São Paulo: Editora DPJ, 2006, p. 267).

${ }^{331}$ VIOLIN, Jordão. Ação Coletiva Passiva: fundamentos e perfis. Salvador: Editora Juspodium, 2008, p. 72-73.

${ }^{332}$ DIDIER JR, Fredie; ZANETI JR., Hermes. Curso de Direito Processual Civil: processo coletivo, v. 4, 5Ed., Salvador: JusPodium, 2010, p. 211-212.
} 
de legitimidade às entidades listadas pela legislação pátria não são suficientes para garantir que os membros ausentes da classe sejam defendidos da melhor forma possível. Esse controle deve ser feito a partir da análise das atividades e da conduta dos representantes no curso do processo e, até mesmo, fora dele $\mathrm{e}^{333}$. No curso do processo, como componente de uma das condições da ação, a representatividade adequada poderá e deverá ser aferida a qualquer tempo pelo juiz, vez que, se deixar de atuar com a diligência necessária, o autor perderá a base de sua legitimidade e será caso de carência superveniente da ação ou, no mínimo, de assunção da causa pelo Ministério Público, para evitar maiores danos à coletividade $^{334}$

Isso decorre do fato que o conceito foi, desde sua gênese, construído como corolário do devido processo legal, pelo que não pode ser negligenciada em nenhuma situação. É a representatividade adequada que, em última análise, assegurará que todos os membros da coletividade ausentes poderão ser atingidos pela decisão de procedência ou improcedência da ação coletiva, de modo que, uma vez tendo o legitimado deixado de atuar como representante adequado da classe - ou seja, deixando de agir de forma idônea, capaz e vigorosa na defesa dos interesses dos representados -, a atribuição da legitimidade ativa pode e deve ser revisitada pelo juiz da causa.

A partir das premissas estabelecidas sobre o tema central deste estudo, é possível concluir que a representatividade é qualidade inerente àqueles que falam em nome dos integrantes de determinada coletividade, e sua adequação será aferida toda vez que esse ente se movimentar para pleitear os interesses de tal coletividade - judicialmente ou extrajudicialmente - mediante um juízo de valor externo que, no processo, será realizado pelo juiz da causa mediante a verificação de características como a idoneidade, a capacidade técnica, o histórico de atuação na defesa dos interesses da classe, entre outros que se mostrem necessários no caso concreto.

$\mathrm{Na}$ doutrina brasileira, conquanto inexista previsão expressa da necessidade e possibilidade de aferição da representatividade adequada, esta é tida como condição da

\footnotetext{
333 Nesse sentido, ver GRINOVER, Ada Pellegrini. Novas questões sobre a legitimação e a coisa julgada...Op. cit., p. 267 e FORNACIARI, Flávia Hellmeister Clito. Representatividade Adequada nos processos coletivos...Op. cit., p. 52.

${ }^{334}$ No mesmo sentido, PASCHOAL, Maximilian Fierro. A representatividade adequada na ação coletiva brasileira...Op. cit., 117. A ideia de assunção do polo ativo pelo parquet, no entanto, apenas resolve a questão com relação às associações - que poderiam ser substituídas pelo Ministério Público -, não resolvendo, por outro lado, a falta de representatividade adequada do próprio órgão ministerial que, como reconhece parte da doutrina, não pode ser presumido como representante adequado de todas as classes em todas as demandas coletivas. Nesse sentido, ver GRINOVER, Ada Pellegrini. Novas questões sobre a legitimação e a coisa julgada...Op. cit., p. 268.
} 
ação - enquanto parte integrante da atribuição de legitimidade ativa para a propositura de ações coletivas.

Fixadas essas bases conceituais, parte-se para uma análise comparativa do instituto da representatividade adequada, desde sua gênese no sistema de Common Law até a sua definitiva consolidação como requisito indispensável e, quiçá, mais importante, para o desenvolvimento das Class Actions norte-americanas. Posteriormente, o foco será trazido para a legislação brasileira, buscando apurar se o ordenamento jurídico pátrio, que se absteve de regulamentar expressamente o instituto, possibilita a aferição ope judicis da representatividade adequada das associações - e, se o faz, por que meios.

\subsection{A REPRESENTATIVIDADE ADEQUADA NO SISTEMA NORTE- AMERICANO}

O capítulo 2, que trata da evolução histórica dos direitos transindividuais e do desenvolvimento dos meios de defesa desses interesses - cujos primeiros registros remontam à Inglaterra do século XII -, discorreu sobre a correlação intrínseca existente entre a representatividade adequada e a própria existência das ações coletivas. A gênese das ações dessa natureza, como anteriormente estudado, se deu com a admissão pelas courts of chancery (responsáveis pela aplicação da jurisdição de equidade na Inglaterra da época) de ações em que alguns membros de determinada classe representassem a coletividade toda. Nasciam as chamadas representative actions, que tinham como requisito a impossibilidade de reunião de todos os membros da classe no polo passivo - que era a regra geral -, em virtude do grande número de integrantes, e, também, a exigência que o autor representante fosse capaz de defender adequadamente os interesses dos membros ausentes $^{335}$.

Assim sendo, a exigência de que o representante defenda de forma idônea e vigorosa os interesses dos integrantes da classe representada é inerente à própria ideia das representative actions, entre as quais está a atual Class Action, visto que para permitir a realização da justiça no caso concreto - possibilitando levar a juízo as demandas que poderiam ter seu acesso às cortes dificultado ou inviabilizado pela exigência do

\footnotetext{
${ }^{335}$ GIDI, Antonio. A Class Action como instrumento de tutela coletiva de direitos...Op cit., p. 42 . Esse mesmo autor anota que, no julgamento Smith v. Swormstedt, a corte manifestou que a criação dessa categoria de ações deveu-se à necessidade de "contornar" a regra do litisconsórcio necessário a todos os interessados, para que fosse possível fazer justiça em situações em que a reunião de todos os legitimados não era possível.
} 
litisconsórcio - foi necessário criar uma alternativa que atendesse, na medida do possível, a garantia do devido processo legal (due process of law), protegido legalmente desde a edição da Magna Carta de $1215^{336}$. Essa garantia, em sua gênese, tinha uma dimensão física, que se traduzia no direito da pessoa ir a juízo, comparecer à presença do juiz e do júri, e só após cumpridos esses requisitos é que era possível falar em restrição de direitos de qualquer natureza. Em outras palavras, a representatividade adequada garantiria que os reclamos da classe fossem ouvidos em juízo (fair hearing) como se todos os membros estivessem presentes ${ }^{337}$.

Por isso, séculos após o surgimento das representative actions na Inglaterra, a doutrina e a jurisprudência norte-americanas reconheceram a representatividade adequada como o requisito mais importante a ser avaliado pelo juiz, já que conserva como seu objetivo a realização, na prática, da garantia constitucional do devido processo legal, circunscrita na V e na XIV emendas da Constituição norte-americana, que garante a todos os cidadãos americanos a oportunidade e o direito de ser ouvido (opportunity to be heard, right to be heard) e o tão prezado direito de estar em juízo (conhecido como day in court $)^{338}$.

\footnotetext{
336 "No free man shall be taken, or impresioned, or desseised, or outlawed, or exiled, or in any way destroyed, nor will we fo upon him, nor will we send upon him, except by the legal judjment of his peers or by the law of the land" (tradução livre: Nenhum homem livre será preso, aprisionado ou privado de uma propriedade, ou tornado fora-da-lei, ou exilado, ou de maneira alguma destruído, nem agiremos contra ele ou mandaremos alguém contra ele, a não ser por julgamento legal dos seus pares, ou pela lei da terra). Ver, sobre o tema, GRINOVER, Ada Pellegrini. As garantias constitucionais do Direito de Ação. São Paulo: RT, 1973, p. 23-25.

${ }^{337}$ PASCHOAL, Maximilan Fierro. A representatividade adequada na ação coletiva brasileira...Op. cit., p. 118. Ver também GIDI, Antonio. "A Class Action como instrumento de tutela...Op. cit., p.100.

338 "No person be held to answer for a capital, or otherwise infamous crime, unless on a presentement or indictment of a Grand Jury, except in cases arising in the land or naval forces, or in the Militia, when in actual service in time of War or public danger; or shall be compelled in any criminal case to be a witness against himself, nor be deprived of life, liberty, or property, without due process of law (...)" (Emenda Constitucional V, de 1791). (Tradução livre: ninguém sera privado de liberdade para responder por crime capital ou outro de natureza infamante, a menos que seja regularmente acusado e processado perante o júri, exceto em casos de levante em terra ou no mar, em tempos de guerra ou perigo público; e não poderá ser obrigado a fazer prova contra si mesmo, nem privado da vida, liberdade ou propriedade sem o devido processo legal).

"All persons born or naturalized in the United States, and subject to the jurisdiction thereof, are citizens of the United States and of the State wherein they reside. No State shall make enforce any law which shall abridges the privileges or immunities of citizens of the United States; nor shall any State deprive any person of life, liberty, or property, without due process of law, nor deny to any person within its jurisdiction the equal protection of the laws" (Emenda Constitucional XIV de 1868) (tradução livre: todas as pessoas nascidas ou naturalizadas norte-americanas, e sujeitas à jurisdição, são cidadãos dos Estados Unidos e do estados em que residem. Nenhum Estado poderá fazer cumprir qualquer lei que restrinja os privilégios ou as imunidades dos cidadãos dos Estados Unidos, e nenhum estado poderá privar qualquer pessoa da vida, liberdade ou propriedade sem o devido processo legal, ou negar a qualquer pessoa em sua jurisdição a igual proteção da lei). Ver, ainda, GIDI, Antonio. A Class Action como instrumento de tutela...Op. Cit., p. 99100.
} 
Uma vez que as Class Actions foram idealizadas justamente para permitir que os efeitos de uma determinada decisão fossem estendidos a todos os integrantes de uma determinada coletividade - sem que todos precisassem ser ouvidos, o que inviabilizaria a tutela - e que, por outro lado, ninguém pudesse ter direitos tolhidos sem que tivesse sido oportunizada a sua defesa e sua oitiva em juízo, pode-se dizer, com toda segurança, que não há Class Actions no sistema norte-americano sem que o representante da classe seja considerado adequado - já que só isso garantirá a extensão dos efeitos da sentença para além das partes litigantes ${ }^{339}$.

\subsubsection{Precedentes dos tribunais norte-americanos determinantes para o desenvolvimento do conceito de representatividade adequada}

A jurisprudência norte-americana, particularmente os precedentes da Suprema Corte, foi gradativamente reconhecendo a vinculação intrínseca entre a representatividade adequada e a própria natureza representativa das Class Actions, conferindo ao requisito importância capital e permitindo a sua verificação e revisão por parte do juiz a qualquer tempo, inclusive após o trânsito em julgado da demanda - já que, ausente a representatividade adequada, haveria afronta direta à garantia constitucional do due process of law, que impediria a submissão, daquele que foi mal representado, aos efeitos da decisão.

Foi o que aconteceu no caso Hansberry v. Lee, considerado como primeiro precedente importante da representatividade adequada entre as cortes norte-americanas,

\footnotetext{
${ }^{339}$ Como assinalado por Jack H. Fridenthal, Mary Key Kane e Arthur R. Miller: "This requirement (adequacy of representation) has a due process dimension to it. Because consideration of efficiency and judicial economy have led to a relaxation in the class section context of the ordinary of the ordinary guarantee of a right to be present in the courtroom when one's rights or liabilities are adjudicated, courts are specially careful to ensure that the absent members have a suitable surrogate. Unless great care in taken to ensure adequacy of representation, an absent class member can avoid being bound by the judgment by attacking it is as being constitutionally flawed. If that occurs, then the efficiencies and the economies sought by permitting the class action in the first instance will be nullified" (tradução livre: esse requisito (representatividade adequada) tem em si uma dimensão do devido processo legal. Porque considerando que a eficiência e a economia judicial levaram a um relaxamento nos processos coletivos das regras que garantem no processo comum o direito de estar presente na corte quando seu direito ou responsabilidade está sendo discutido, os tribunais têm tomado especial cuidado para assegurar que os membros ausentes tenham um substituto adequado. A menos que um grande cuidado seja tomado para assegurar a representatividade adequada, um membro da classe pode evitar ser vinculado pelo julgamento alegando uma falha constitucional. Se isso ocorrer, então a eficiência e a economia ganhas ao permitir a ação de classe serão perdidas.). FRIDENTHAL, Jack H.; KANE, Mary Key; MILLER, Arthur R. Civil Procedure. 2. ed. West Publishing Co., 1993, p. 730-731.
} 
nos idos da década de $1940^{340}$. Nesse caso, o autor (Hansberry) era um afro-americano que comprara um terreno em um loteamento que teria uma vedação estatutária à alienação de lotes a pessoas negras. Com base nessa vedação, parte dos moradores ingressou com uma demanda assinalando que esse assunto já teria sido debatido em Class Action anteriormente ajuizada (Burke v. Kleiman) em que se decidiu pela existência e validade da vedação em questão.

Entretanto, o senhor Hansberry trouxe aos autos da demanda, em que figurava como réu, a alegação de que a vedação somente seria válida se subscrita por $95 \%$ dos proprietários de terrenos daquele loteamento, tendo ficado demonstrado que ela fora subscrita apenas por $54 \%$ dos proprietários - o que não teria sido objeto de discussão em Burke v. Kleiman. Tendo o réu perdido em todas as instâncias ordinárias, por ter sido considerado que o primeiro precedente seria vinculante ao antigo proprietário do imóvel e, por conseguinte, a ele, levou o caso à Suprema Corte dos Estados Unidos, que reverteu as decisões anteriores.

O fundamento da reversão é o que efetivamente suscitou interesse. A Suprema Corte entendeu que o caso usado como paradigma para julgar a questão (Burke v. Kleiman) não poderia ter sido tratado como Class Action desde sua gênese, uma vez que, se apenas pouco mais da metade dos proprietários de lotes (54\%) tinha subscrito a vedação, o representante (senhor Burke) poderia, no máximo, ser um representante adequado para essa parcela dos representados - quanto aos demais, ou seja, os outros $46 \%$ dos proprietários de lotes, haveria conflito de interesses. A revisão da representatividade adequada no caso paradigma levou à reversão do julgado na ação proposta contra o senhor Hansberry, por se ter entendido que o julgado naquela ação não lhe poderia afetar, já que isso implicaria em séria violação de suas garantias constitucionais. Tal violação consitiria no fato de que tanto ele quanto os demais, atuais e futuros, proprietários de loteamentos não haviam sido cientificados da existência da ação coletiva, tampouco lhes teria sido oportunizado o direito de defesa ${ }^{341}$.

Assim, antes mesmo da reforma da Rule 23 que, no ano de 1966 sistematizou de forma mais detalhada o sistema das ações coletivas e inseriu a representatividade adequada como requisito para a certificação da Class Action, a jurisprudência norte-americana já

\footnotetext{
${ }^{340}$ PASCHOAL, Maximilian Fierro. A representatividade adequada na ação coletiva brasileira...Op. Cit., p. 119.

${ }^{341}$ LEE ANDERSON. Preserving adequacy of representation when dropping claims in class action. Kansas City, Missouri: UMKC Law Rewiew, vol. 74:1, 2005, p. 125.
} 
vinha tratando o instituto dessa forma ${ }^{342}$, deixando claro que os casos de collateral attack quando há impugnação sobre a adequação do representante e acerca da extensão dos efeitos da coisa julgada após o trânsito em julgado - não só são possíveis, como têm o condão de alterar a certificação e, por conseguinte, a extensão dos efeitos da decisão prolatada e transitada em julgado. É um requisito de tal forma importante que pode ser revisto perpetuamente.

Essa orientação aparece novamente no caso Gonzales v. Cassidy, datado de 1973, proposta em benefício de taxistas envolvidos em acidentes e que perdiam sua habilitação por ausência de seguro, o autor de uma demanda anterior teve sua representatividade adequada questionada, pela via do collateral atack. A United States Court of Appels - Fifth Circuit, em sua decisão, deixou claro que a adequação do representante da classe poderia ser verificada partindo da resposta de duas perguntas: (i) $\mathrm{O}$ tribunal que primeiro apreciou a questão verificou de forma correta se o representante teria condições de representar adequadamente a classe?; e (ii) Após o encerramento da demanda, é possível aferir que o representante efetivamente protegeu os interesses da classe ${ }^{343}$ ? No caso, entendeu-se que o representante não seria adequado já que, muito embora esse requisito tenha sido aferido no início da demanda - portanto, respondida afirmativamente a primeira pergunta -, não defendeu com o vigor e a tenacidade desejáveis os interesses da classe (deixando de responder a segunda questão), limitando-se a defender com mais cuidado os direitos daqueles que estavam em situação análoga à sua ${ }^{344}$.

A identidade de interesses entre os representantes e representados - na maioria das vezes identificada pelo fato de que o representante também teve um direito seu violado e busca a reparação em juízo ${ }^{345}$-, especialmente quando coexistem em uma mesma

${ }^{342}$ PASCHOAL, Maximilian Fierro. A representatividade adequada na ação coletiva brasileira...Op. cit., p. 122.

${ }^{343}$ Tradução livre do trecho que constou na decisão do tribunal. No original: "(1) Did the trial court in the first suit correctly determine, initially, that the representative would adequately represent the class? and (2) Does it appear, after the termination of the suit, that the class representative adequately protected the interest of the class?" Disponível em: http://openjurist.org/474/f2d/67/gonzales-v-w-cassidy-iii. Acessado em 18jun.2011.

344 FORNACIARI, Flávia Hellmeister Clito. Representatividade adequada nas ações coletivas brasileiras...Op. cit., p. 57.

${ }^{345}$ Embora existam julgados, como bem apontado por Maximilian Fierro Paschoal, que tenham reconhecido a representatividade adequada de pessoas não integrantes da classe representada, como o julgado em Kagan v. Gibraltar Savings and Loans Association, em que uma consumidora, cujos danos causados pela empresa já tinham sido integralmente reparados, apresentou-se em juízo como representante da classe cujos integrantes tivessem sofrido o mesmo tipo de dano, tendo sido a ação certificada e sua representatividade adequada reconhecida. A orientação majoritária da doutrina americana, no entanto, indica que o autor, e também representante, da classe deve ser titular dos direitos que pleiteará em juízo. (PASCHOAL, Maximilian Fierro. A representatividade adequada na ação coletiva brasileira...Op. cit., p. 127-128). 
coletividade interesses diversos em relação a um mesmo fato foi o que se observou no supracitado caso Hansberry v. Lee e que se repetiu outras vezes ao longo dos anos, como, por exemplo, no caso Johnson v. Uncle Ben's - Class Action sobre discriminação feita pela empresa ré na contratação de empregados negros e latinos, em que se decidiu que a solução dada ao caso só atingiria os empregados negros, já que o representante não teria defendido de forma adequada os interesses dos latinos ${ }^{346}$-, e, ainda, no caso que ficou conhecido como "Agente Laranja",347, apontado como primeira Class Action para a reparação de danos individuais em larguíssima escala certificada pelos tribunais norte-americanos ${ }^{348}$.

Nota-se que, partindo de uma breve disposição da Regra 23, que arrola entre os requisitos para certificação a necessidade de comprovação de que a parte representará adequadamente os interesses dos membros da classe, foi a jurisprudência das cortes

${ }^{346}$ Foi também a United States Court os Appeals - Fifth Circuit que apreciou o caso em questão, tendo anotado que, muito embora tivesse sido certificada a Class Action em um primeiro momento, reconhecida a representatividade adequada do autor, no decorrer da demanda percebeu-se que a defesa dele em relação aos integrantes latinos da classe deixava a desejar, pelo que estes últimos tiveram suas garantias constitucionais violadas. Nas palavras utilizadas pelo próprio órgão julgador: "The district court originally, and at the time quite correctly, determined that plaintiff would adequately represent the certified class of blacks and Maexican-Americans. At trial, however, representation of the class of Mexican-Americans was not adequate. The trust of plantiffs' direct case concerned the situation involving black employees. Although this may well have been necessary on the issue of promotion considering the small number of Mexican-Americans employed by Uncle Ben's, plantiffs' preoccupation with the issue of black promotion seemingly led them to omit to introduce into evidence the number of Mexican-Americans hired by Uncle Ben's. (...) To remedy the trial court's failure in this respect we now hold that dismissal s all claims regarding Mexican-Americans is without prejudice. This judgment does not have res judicata effect against them (...)" (tradução livre: $\mathrm{O}$ tribunal distrital originalmente, e naquela época corretamente, determinou que o autor defenderia adequadamente os interesses de afro-americanos e mexicanos. No julgamento, entretanto, a representação da classe dos mexicanos não foi adequada. O representante dos autores dirigiu sua defesa para os afroamericanos. E conquanto isso possa ter sido necessário, dado o pequeno número de mexicanos empregados pela Uncle Ben's, a preocupação do autor com as questões referentes à promoção dos direitos dos negros levou à omissão das questões e dos números referentes aos mexicanos contratados pela Uncle Ben's. (...) Para remediar a falha do tribunal nesse tocante nós rejeitamos os pleitos dos mexicanos sem prejuízo. Essa decisão não tem efeitos e não faz coisa julgada contra eles (...). , disponível no website http://openjurist.org/628/f2d/419/johnson-v-uncle-bens-inc. Acessado em 18.jun.2011.

347 O caso do "Agente Laranja" envolvia os veteranos da guerra do Vietnã, que foram expostos a um determinado composto químico durante a batalha, tendo sido demonstrado, posteriormente, que esse composto causava severos danos à saúde. Foi proposta a Class Action, tendo sido notificados pelos mais diversos meios de comunicação (jornais, rádio, televisão), todos os veteranos da guerra do Vietnã no período em que o composto químico fora utilizado. Terminada a fase de certificação, foi celebrado o acordo, tendo sido destinada uma parcela para a indenização dos veteranos doentes ou para as famílias dos falecidos em razão da exposição ao agente laranja, uma parcela para indenizar os veteranos que tivessem exercido o opt out e uma parcela que seria destinada ao tratamento de todos os veteranos de guerra. Anos depois, um veterano de guerra ingressa com demanda, veiculando pretensão indenizatória por danos à sua saúde causados pelo agente laranja e a corte do Second Circuit entende que ele não estaria vinculado ao acordo firmado anteriormente, pois os direitos daqueles que ainda não haviam desenvolvido doenças em virtude de exposição ao produto tóxico não foram adequadamente representados. Na suprema corte houve empate entre os juízes votantes, o que permitiu o processamento do caso regularmente, não estando o autor vinculado ao acordo realizado anteriormente, ver PASCHOAL, Maximilian Fierro. A representatividade adequada na ação coletiva brasileira...Op. cit., 134-135.

${ }^{348}$ HENSLER, Deborah (et. alli). Class Action Dilemmas - pursuing public goals for private gain. Santa Monica, California: Ed. RAND, 2000, p. 24-25. 
americanas que preencheram o conceito de representante adequado. Isso se deu não apenas porque o sistema de Common Law tem como fundamento a força vinculante dos precedentes, mas também porque, como já se destacou, a representatividade adequada só pode ser aferida em cada caso concreto, sendo inviável predeterminar e positivar todas as suas possibilidades.

A doutrina norte-americana, partindo dos julgados que abordam o tema da representatividade adequada e observando o comportamento dos juízes e dos tribunais quando da aferição desse requisito no momento da certificação das Class Actions a eles submetidas, listou alguns critérios para a sua verificação. Grande parte dos estudiosos do tema entende justificável verificar a representatividade também do advogado da classe, como destacam Debra Lyn Bassett ${ }^{349}$ e Antonio Gidi ${ }^{350}$.

Entretanto, embora com algum nível de divergência, já que não se pode falar em um rol taxativo nesse tema, a professora Linda Mullenix resumiu com sucesso os critérios a serem verificados pelo juiz para aferir a adequação do representante: (1) ausência de conflito de interesses entre o representante da classe e seus membros; (2) o representante da classe fará uma defesa una de todos os interesses; (3) o representante da classe é alguém próximo do conselho da classe; (4) o representante não deve ter pleitos contra o réu diversos daqueles da classe; (5) o representante deve estar familiarizado com o tema da ação; (6) o representante não deve ceder o controle da causa ao conselho da classe; (7) o representante não pode ter idade avançada ou estar em condições de saúde que o impeçam de conduzir bem a ação; (8 e 9) o representante da classe deve ter meios financeiros suficientes para financiar o processo e as verbas dele decorrentes; e (10) o representante deve ter estatura moral para defender a classe, o que inclui a demonstração de honestidade, credibilidade e pureza de motivos ${ }^{351}$.

\footnotetext{
${ }^{349}$ LYN BASSETT, Debra. When reform is not enough: Assuring more than 'adequate' representation in class actions. Georgia: Law Review, vol. 30:927, 2004, p. 927 a 989.

350 GIDI, Antonio. A Class Action como instrumento de tutela coletiva de direitos...Op cit., p.110-112 e 120-124.

${ }^{351}$ MULLENIX, Linda. Taking adequacy seriously: the inadequate assessment of adequacy in litigation and settlement classes. Vanderbilt: Law Rewiew, vol. 57:5:1687, 2004, p. 1704 e 1705. No original: "(1) The proposed class representative has interests that are in conflict with or antagonistic to other class members; (2) the class representative is subject to a unique defense; (3) the class representative is closely affiliated with class counsel; (4) the class representative has claims against the defendant other than the class claims; (5) the class representative is familiar with the action; (6) the class representative has ceded control over the litigation to class counsel; (7) the class representative is of advanced age, in ill health, or suffering from other disability; (8) the class representative has sufficient finance stake in the outcome of the litigation; (9) the class representative has the ability to finance the litigation; and (10) the class representative in of sufficient moral character to represent a class, including whether the representative displays traits of honesty, credibility and purity of motive.".
} 
O que se apreende dessa postura da jurisprudência e da doutrina acerca do controle da representatividade adequada nas Class Actions norte-americanas é que, para além da previsão na Regra 23 das Rules of Civil Procedure, a base dessa necessidade está na garantia constitucional do devido processo legal (due process of law) e na promessa que fundamenta o estado democrático de direito, no qual ninguém será tolhido de bens e direitos sem ser ouvido e sem ter tido a oportunidade de se defender perante a justiça. E esse é um dos motivos pelos quais, desde a gênese das ações coletivas nos países de Common Law, não se observou nenhum movimento ou tendência de flexibilização na aferição desse requisito.

Pelo contrário, em geral, o que se observa é um constante recrudescimento, principalmente diante do atual quadro de afluxo de demandas veiculando danos individuais (Class Actions for Damages), em que a verificação da representatividade adequada tem o condão de garantir a boa defesa dos direitos dos ausentes e, também, de minimizar riscos de colusão e outras condutas abusivas perpetradas pelos representantes que buscam benefícios próprios e não o bom termo do processo e a efetivação dos interesses da coletividade.

E se a Constituição Federal brasileira também prevê, entre suas garantias fundamentais, o respeito ao devido processo legal, e sendo o desenvolvimento de um sistema sólido de defesa dos interesses transindividuais indispensável para efetivar de forma mais ampla e menos custosa o acesso à justiça, torna-se indispensável verificar de que forma nosso sistema tem garantido que os autores de demandas coletivas realmente representem em juízo, da melhor forma possível, os direitos dos integrantes de determinada classe, o que será analisado com maior vagar no próximo capítulo.

\subsection{A REPRESENTATIVIDADE ADEQUADA EM OUTROS ORDENAMENTOS JURÍDICOS}

Para ter uma visão mais completa do instituto da representatividade adequada, caberá analisar com maior vagar as experiências de outros países com o conceito, tenha ele sido positivado nos respectivos ordenamentos jurídicos ou simplesmente se desenvolvido pela jurisprudência por meio do controle jurisdicional. Iniciando-se por outros países que 
adotam a sistemática da Common Law - e, portanto, sofreram influência direta do que ocorreu nos Estados Unidos -, para, posteriormente, passar aos países da tradição jurídica de Civil Law, nos mesmos moldes que foi desenvolvido no capítulo inicial sobre o histórico da tutela dos direitos transindividuais nesses ordenamentos.

Finalmente, serão analisadas as tentativas de positivação do conceito de representatividade adequada no ordenamento jurídico brasileiro que, até o momento, não lograram êxito em especificar a possibilidade e os parâmetros para essa aferição pelos magistrados.

\subsubsection{Austrália e Canadá}

A Austrália e o Canadá, como representantes do sistema jurídico de Common law, herdaram, em grande medida, os institutos do direito norte-americano, especialmente no que concerne à defesa dos interesses coletivos, já que foi nos Estados Unidos que as ações dessa natureza se desenvolveram com maior riqueza.

$\mathrm{Na}$ Austrália, a disciplina dos processos coletivos foi positivada de forma sistemática, no âmbito federal, no ano de 1992, com a entrada em vigor de uma série de dispositivos chamados de "processos representativos" (representative proceedings). Tendo em vista que a jurisdição da Corte Federal australiana abarca casos de direitos da concorrência, defesa do consumidor e, ainda, causas estaduais associadas a ações federais, verifica-se que o alcance das disposições relativas aos processos representativos é relativamente grande ${ }^{352}$. Ademais, é preciso considerar que alguns Estados australianos positivaram normas relativas à tutela dos interesses transindividuais em seus regramentos próprios $^{353}$.

Para além das diversas diferenças que podem ser observadas entre as ações representativas australianas e as class actions norte-americanas, é certo que o legislador australiano foi bastante restritivo ao positivar a aferição da representatividade adequada. Isso porque, pelo texto literal do artigo $33 \mathrm{~T}$ do Federal Court Act ${ }^{354}$, somente a partir do

\footnotetext{
${ }^{352}$ PASCHOAL, Maximilian Fierro. A representatividade adequada na ação coletiva brasileira...Op. cit., p.192.

${ }^{353}$ A Austrália está organizada na forma federativa e é composta por seis Estados-membros. No ano de 1999, o Estado de Victoria inseriu em seu regramento processual dispositivos contemplando os procedimentos representativos. Sobre o tema ver MENDES, Aluísio Gonçalves de Castro. Ações Coletivas no direito comparado e nacional. 2. ed. São Paulo: Ed. RT, 2010, p.157.

$35433 \mathrm{~T}$ (1) If, on an application by a group member, it appears to the Court that a representative party is not able adequately to represent the interests of the group members, the Court may substitute another group
} 
requerimento de alguma parte interessada é que o juiz poderia realizar a aferição da representatividade adequada do autor, determinando sua substituição por outro membro do grupo ou outras providências, quando necessário. Se interpretado dessa forma, o condicionamento da aferição a manifestação de um interessado poderia acabar implicando na violação ao devido processo legal ${ }^{355}$.

Ocorre que, em todo o regramento dos representative proceedings (artigos 33A até 33ZJ do Federal Court Act), foram conferidos ao juiz amplos poderes de direção do processo - desde a determinação de provas que entender necessária para o deslinde do feito (artigo 33Q e 33R) até a redistribuição de custos do processo (artigo 33M) -, pelo que não se coadunaria com a lógica do sistema que o artigo 33T limitasse a atuação jurisdicional acerca da representatividade do autor coletivo apenas aos casos em que essa questão for suscitada por outro integrante da classe. Por isso, há quem entenda que qualquer irregularidade na representatividade da parte autora poderá ser verificada pelo juiz - que, então, aplicará o artigo $33 \mathrm{~T}$ e substituirá o representante da classe ${ }^{356}$.

O Canadá, bem como a Austrália, adotou o sistema federativo, de modo que cada um dos Estados canadenses tem uma legislação própria e independente. No que toca à defesa dos direitos coletivos no Canadá, várias províncias positivaram regras para processos coletivos, tendência que foi iniciada por Quebec - diga-se, província que adota o sistema de Civil law - em 1978, seguida pelas outras províncias como Ontário (1993), British Columbia (1995), Saskatchewan (2002), Newfoundland (2002) e Manitoba (2002). Há também regras da Corte Federal Canadense (2002) e da Corte Suprema do Canadá (2001) que, conquanto sejam compilações das regras das províncias - que à época já tinham positivado regras a respeito -, contribuíram com a introdução do regramento dos processos coletivos em províncias que ainda não tinham positivado legislação específica sobre o tema357.

member as representative party and may make such other orders as it thinks fit. (tradução livre: se, a requerimento de um membro do grupo, parecer ao tribunal que a parte representante não é capaz de representar adequadamente os interesses dos membros do grupo, o tribunal poderá substituir por outro membro do grupo, decretando-o representante do grupo e determinando outras providências).

${ }^{355}$ MENDES, Aluísio Gonçalves de Castro. Ações Coletivas no direito comparado e nacional...Op. cit., p 160.

${ }^{356}$ PASCHOAL, Maximilian Fierro. A representatividade adequada na ação coletiva brasileira...Op. cit., p. 195.

357 Ver "Las Actiones Colectivas en Canadá" (WATSON, Gary D. In: GIDI, Antonio; MAC-GREGOR, Eduardo Ferrer. Processos Colectivos - la tutela de los derechos difusos, colectivos e individuales em uma perspectiva comparada. Cidade do México: Porrúa, 2004, p. 29. Ver, ainda PASCHOAL, Maximilian Fierro. A representatividade adequada na ação coletiva brasileira...Op. cit., p. 197. 
Conforme visto, a representatividade adequada está positivada no ordenamento jurídico canadense em todas as províncias do país, bem como nas regras gerais estabelecidas pela Corte Suprema e pela Corte Federal. Em linhas gerais, toda a legislação canadense considera que:

O autor ideológico deve representar justa e adequadamente os interesses da classe, não apresentando interesses conflitantes com outros membros do grupo e tendo um plano de atuação viável para o processamento do feito ${ }^{358}$.

Assim, seguindo os mesmos moldes da legislação americana - de onde foi herdada a inspiração para as regras de processos coletivos -, as diversas leis vigentes no Canadá sobre a tutela dos interesses transindividuais positivaram a exigência da representatividade adequada dos autores coletivos, ainda que não tracem parâmetros a serem observados com o intuito de verificar a adequação do comportamento do representante. Esse requisito foi levado tão a sério pelo legislador que, em algumas províncias, como Quebec, pode haver mais de um representante adequado na mesma ação, sendo criadas subclasses de autores com interesses e representantes próprios ${ }^{359}$.

Sobre quem pode iniciar a ação coletiva e, por conseguinte, estar sujeito a verificação da representatividade adequada, a jurisprudência de grande parte das províncias canadenses entendeu que deve se tratar de um membro da classe afetada pelo direito discutido em juízo e, ainda, residir na própria província. Entretanto, está positivado em algumas províncias, a exemplo da regulamentação de Sasktchewan, que o representante pode ser eleito pelo juiz, o qual pode considerar pessoas que não pertençam à classe, se isso se coadunar com os interesses de toda a coletividade ou se assim for considerado melhor para a administração da justiça ${ }^{360}$.

Especificamente no que diz respeito à possibilidade de propositura de ações coletivas por corporações ou associações, a província de Quebec positivou essa hipótese,

\footnotetext{
${ }^{358}$ MENDES, Aluísio Gonçalves de Castro. Ações Coletivas no direito comparado e nacional...Op. Cit., p 144.

${ }^{359}$ PASCHOAL, Maximilian Fierro. A representatividade adequada na ação coletiva brasileira...Op. cit., p. 200.

${ }^{360}$ Citem-se, como exemplos, as províncias em que se decidiu que o autor coletivo deve ser residente na própria província, a de Ontário, Britsh Columbia, Newfoundland e Saskatchewan. No regramento de processos coletivos da província de Saskatchewan, sobre a possibilidade de nomear quem não seja membro do grupo para ser representante da classe, foi positivado o seguinte: 4(4) Where it is necessary to do so in order to avoid a substancial injustice to the class, the court may appoint a person who is not member of the class as the 'representative plaintiff for the class action' (tradução livre: onde for necessário, para evitar injustiças para com a classe, o tribunal poderá nomear uma pessoa que não é membro da classe para ser o autor coletivo). Nesse sentido, ver PASCHOAL, Maximilian Fierro. A representatividade adequada na ação coletiva brasileira...Op. cit., p. 201-202.
} 
listando, entretanto, requisitos que devem ser atendidos pelas pessoas jurídicas em questão, além da representatividade adequada. Entre eles estão a necessidade que a corporação/associação tenha pelo menos 50 empregados no período de 12 meses que antecedem a certificação da class action e pelo menos um integrante da entidade com interesse próprio e direto na demanda proposta ${ }^{361}$.

De uma forma geral, é possível dizer que as cortes canadenses buscam eleger como representante adequado alguém que seja membro da classe, com residência na província onde ocorreu o dano e onde se localiza o tribunal que analisará a causa, que tenha interesse em comum com a classe que pretende defender, que conheça os fatos da demanda e que tenha o propósito de atuar de forma idônea e vigorosa - na maioria dos casos representados por advogados com o conhecimento técnico necessário para tanto. Contudo, vale dizer que não necessariamente a triagem será feita em busca do melhor representante possível ${ }^{362}$.

Observa-se, portanto, que em outros ordenamentos jurídicos de Common Law, além do americano, a representatividade adequada foi contemplada - com mais ou menos detalhes, com mais ou menos rigor - e as experiências das cortes desses países têm demonstrado que a aferição desse requisito, de fato, é necessária e desejável para a manutenção do sistema. Essa experiência tem muito a acrescentar aos países de Civil law. Aliás, cumpre lembrar que no ordenamento jurídico canadense a positivação do requisito da representatividade adequada se deu em primeiro lugar em uma província que adota o sistema romanístico, a província de Quebec ${ }^{363}$.

Passa-se, então, à análise da representatividade adequada nos países de Civil Law, buscando identificar alguns dos países que seguem a tradição romano-germânica e, ainda assim, positivaram a necessidade de aferição desse requisito como forma de garantir que os interesses dos membros ausentes da classe - cuja esfera jurídica será atingida pela decisão coletiva - sejam representados da melhor forma possível, em atenção ao princípio básico do devido processo legal.

\footnotetext{
${ }^{361}$ Trata-se do artigo 1048 do Código de Processo da província de Quebec (Code of Civil Procedure). Ibid., p. 203.

362 Ibid., p. 204.

${ }^{363}$ MENDES, Aluísio Gonçalves de Castro. Ações Coletivas no direito comparado e nacional...Op. cit., p 142 e PASCHOAL, Maximilian Fierro. PASCHOAL, Maximilian Fierro. A representatividade adequada na ação coletiva brasileira...Op. cit., p. 2012.
} 


\subsubsection{Itália}

A tutela dos interesses transindividuais na Itália - bem como em toda a Europa continental - teve início com uma fase que priorizou as providências inibitórias, deixando de dar a devida atenção à necessidade de ressarcir os danos sofridos pelos indivíduos. Essa realidade, no contexto da legislação italiana, se prolongou até recentemente, com a entrada em vigor da Lei $\mathrm{n}^{\circ} 99$ de 23.07.2009, que modificou o artigo 140 do Codice del Consumo (Código de Defesa do Consumidor Italiano) e possibilitou a tutela dos direitos individuais homogêneos - especificamente no que diz respeito aos consumidores - e, também, a tutela ressarcitória dos danos individualmente sofridos, com base na sentença da ação coletiva ${ }^{364}$.

Ressalte-se que a legislação italiana, até bem pouco tempo atrás, não se ocupou de criar regras próprias para a tutela dos interesses transindividuais, utilizando regras do processo civil comum - eminentemente individual - para resolver problemas nas ações coletivas, o que retardou sobremaneira a consolidação de institutos próprios desse tipo de processo $^{365}$.

Até o ano de 2009, com a entrada em vigor da referida lei que alterou o Codice del Consumo, não havia previsão da necessidade de se aferir a representatividade adequada dos autores das ações que se prestavam à tutela dos interesses transindividuais. Com a criação dessa fase de certificação, o artigo 104.6 passou a constar da lei com nova redação, que cria para o tribunal o dever de verificar alguns pontos antes de admitir a demanda, entre eles se ação coletiva é manifestamente infundada, se os direitos nela tratados podem

\footnotetext{
${ }^{364}$ Ver Capítulo 2, subitem 2.2.2.1.

365 "In Italy, collective actions are provided for by individual statutes or statutory instruments: occasionally, they lay down special rules of procedures, but if this is not the case, the general, ordinary rules governing civil procedure apply. In other words, unless otherwise stated by the law collective actions are no different from any other civil action, at least from a strictly procedural point of view. The system treats association or the public body granted the right of action as an individual plaintiff: there is no need for opt-in or opting-out mechanisms, since in the eyes of the law individual consumers, workers, and so on have no business taking part in the lawsuit”. (Tradução livre: Na Itália, as ações coletivas são reguladas por diplomas esparsos: ocasionalmente, eles trazem algumas regras processuais especiais, mas se não for esse o caso - como em geral acontece - as regras que regem o processo civil comum se aplicam. Em outras palavras, a menos que estabelecido pela lei, os processos coletivos não são diferentes de qualquer outra ação civil, pelo menos do ponto de vista processual. O sistema atribui legitimidade às associações ou aos órgãos públicos como o faz com os autores individuais: não há necessidade de previsão de mecanismos de opt-in ou opt-out, desde que aos olhos da lei individual consumidores, trabalhadores e etc não tenham interesse na causa). Trecho reportado por Elisabetta Silvestri (HENSLER, Deborah R.; HODGES, Christopher; TULIBACKA, Magdalena (et. alli). The Globalization of Class Action: The annals of the american academy of political and social science. Thousand Oaks, California: Sage Publications, Vol. 622, March 2009, p. 144-145.
} 
ser tutelados pela via coletiva e, por fim, se o autor tem condições de defender adequadamente os interesses da classe. ${ }^{366}$

Alguns autores italianos interpretaram que a regra de certificação que condiciona a admissibilidade da demanda apenas após a verificação da representatividade adequada do requerente, por ser posterior àquela que atribui a legitimidade às associações e órgãos públicos - que já era garantida pelo Codice del Consumo antes da reforma -, apenas seria cobrada de outras entidades, além daquelas já previstas em lei, e que se prestassem à defesa dos direitos transindividuais dos consumidores ${ }^{367}$.

A leitura do artigo, entretanto, não deixa entrever essa diferenciação. Fala-se em demanda inadmissível nos casos em que o autor não se mostra apto a defender adequadamente os interesses da classe. Ademais, na Itália, assim como no Brasil, as regras de direito processual se aplicam imediatamente. Na lição de Chiovenda, ainda que não seja exatamente preciso afirmar que as regras processuais têm aplicabilidade imediata, é certo que elas se aplicarão aos processos em curso, para os atos que vierem a ser praticados ${ }^{368}$. Assim, ainda que se assuma uma postura conservadora, de que o artigo não poderia ser aplicado para verificar a representatividade adequada de todos os autores de demandas coletivas já em curso, sabe-se que essa verificação poderá e deverá ser feita em todas as ações coletivas ajuizadas a partir de julho de 2009.

\footnotetext{
366 "All'esito della prima udienza il tribunale decide con ordinanza sull'ammissibilità della domanda, ma può sospendere il giudizio quando sui fatti rilevanti ai fini des decidere è in corso un 'istruttoria davanti a un'autorità independente ovvero um giudizio davanti al giudice amministrativo. La domanda è dichiarata inammissibile quando è manifestamente infondata, quando sussite um conflito di interessi ovvero quando il giudice non ravvisa l'ídentità dei diritti individuali tutelabili ai sensi del comma 2, nonchè quando il proponente non appare in grado di curare adeguatamente l'interesse della classe". (tradução livre: Na primeira audiência o tribunal decide sobre a admissibilidade da demanda [...]. A demanda é declarada inadmissível quando é manifestamente infundada, quando existe conflito de interesses ou quando o juiz não identifica os direitos individuais tutelados de acordo com o parágrafo 2, ou caso o requerente não seja capaz de representar adequadamente os interesses da classe).

367 Opinião manifestada por Elisabetta Silvestri: "In principle, standing to sue is granted to the same qualified entities that, as noted earlier, may bring collective actions for injunctive relief, but standing may be granted to other entities as well, insofar as they adequately represent the collective interests for whose enforcement the action is commenced" (tradução livre: Em princípio, a legitimidade para agir é garantida às mesmas entidades qualificadas que, como anotado anteriormente, podem ajuizar ações coletivas com finalidade de alcançar medidas de injunção, mas a legitimidade pode ser assegurada a outras entidades também, desde que representem adequadamente os interesses pleiteados na ação), ver: HENSLER, Deborah R.; HODGES, Christopher; TULIBACKA, Magdalena (et. alli). The Globalization of Class Action...Op. cit., p. 145-146.

${ }^{368}$ CHIOVENDA, Giuseppe. Instituições de Direito Processual Civil. Vol I. Campinas: Bookseller, 1998, p. 115-117.
} 


\subsubsection{Alemanha}

No que tange à representatividade adequada, não é possível identificar no ordenamento jurídico alemão a positivação da necessidade de sua aferição ou da indicação expressa de critérios para garantir sua efetivação. Entretanto, interessa para este estudo citar o exemplo alemão, pois figuras análogas a do representante adequado - e critérios para sua identificação - permeiam as regras que tratam de processos coletivos naquele país, e a preocupação com o devido processo legal determina a seleção de legitimados idôneos para propositura de processos coletivos.

No âmbito das Verbandsklagen, que são as ações movidas especificamente por associações $^{369}$ - em sua maioria para a proteção da concorrência e do comércio -, foi prevista uma série de exigências nas quais as associações que pretendem ingressar com demandas dessa natureza precisam se enquadrar para poderem ir a juízo. - São eles: (i) serem organizações que têm como propósito a defesa dos interesses comerciais ou de profissionais independentes; (ii) ter capacidade legal; (iii) ter um número considerável de membros (no mínimo 75 membros - pessoas físicas); (iv) estrutura organizacional, pessoal e financeira suficientes para promover a defesa dos temas a que se propuseram.

Nas diretivas da União Europeia foi regulamentada a figura da "Qualified Entity" (entidade qualificada) para a defesa dos interesses dos consumidores. Essas entidades, para que possam atuar na Alemanha, devem estar inscritas junto ao órgão pertinente (Bundesamt für Justiz) ou - se tiverem sede em outro país da Europa - junto à Comissão Europeia. Para se registrar como entidade qualificada na Alemanha e assim poder defender os interesses dos consumidores por meio das Verbandsklagen, há que se preencher uma série de requisitos - entre eles demonstrar a capacidade de defender os interesses do consumidor por meio da informação e de aconselhamento ${ }^{370}$.

\footnotetext{
${ }^{369}$ Cf. capítulo 2, subitem 2.2.2.2.

${ }^{370}$ Nesse sentido, ver artigo de Dietmar Baetge: “Association complaints may be initiated by organizations whose purpose in to promote commercial or independent professional interests. Besides having legal capacity and a "considerable number" of members from among the business community, organizations must also possess enough personnel, organizational, and financial resources to actively promote commercial interests. In addition, association suits may be brought by so-called "qualified entities" within the meaning of the EC Directive on injunctions for the protection of consumers' interests. "Qualified entities" are consumers associations, either registered with the Federal Office for Justice (Budesamt für Justiz) in Bonn or, in case of an organization from another EU member state, with the European Commission. To be registered in Germany, qualified entities must fulfill certain requirements, including legal capacity and to capability to promote the interests of consumers through information and advice”. (tradução livre: As lides por associações podem ser iniciadas por organizações cujo propósito seja promover os interesses comerciais ou de profissionais independentes. Além de ter capacidade legal e um número considerável de membros da
} 
Ou seja, ao atribuir a legitimidade para associações promoverem ações em prol do interesse da coletividade - seja para defender o mercado e a concorrência, ou para tutelar os interesses dos consumidores de acordo com as diretrizes da União Europeia -, a legislação alemã estabeleceu critérios de ordem ideológica, organizacional e econômica a serem atendidos. Tais critérios se prestam a apurar a capacidade da entidade para defender adequadamente os direitos que se propôs a tutelar, em juízo e fora dele. Assim, conquanto a legislação não fale em aferição da representatividade adequada, ela preconiza que apenas preenchendo todos esses requisitos é que a associação poderá ser considerada legítima para propor uma Verbandsklage $e^{371}$.

É possível, portanto, afirmar que a representatividade adequada é exigida às associações que pretendem tutelar direitos coletivos na Alemanha, ainda que a aferição dessa qualidade do legitimado seja feita a priori, antes mesmo do ajuizamento da ação, em alguns casos exigindo mesmo um registro específico para a atuação como representante da coletividade.

No que tange ao Musterprocezeß, que parte da seleção de um caso para solucionar uma controvérsia que atinge a muitas pessoas, se identificando mais com a coletivização de demandas individuais do que com uma demanda coletiva em $\mathrm{si}^{372}$, não há previsão de representante adequado para o grupo. Isso porque não é possível falar em uma "classe", já que a união entre os demandantes é circunstancial e posterior ao ajuizamento da demanda. Nos processos que assumem essa forma, quando o tribunal seleciona um caso como paradigma da questão, e determina a aplicação da decisão a todos os demais casos idênticos, o autor dessa demanda passa a ser considerado o "representante" de todos os autores. Entretanto, a preocupação com o devido processo legal é tão premente que é garantido a todos os demais autores o direito de se manifestar no processo escolhido como

comunidade, as organizações também devem ter recursos pessoais, organizacionais e financeiros para promover os interesses. Em adição, as ações promovidas por associações podem ser trazidas por "entidades qualificadas"com o significado que lhes emprestou a diretiva da EU no que tange às injunções para proteção dos interesses do consumidor. "Entidades qualificadas" são associações de defesa do consumidor registradas no Serviço Federal de Justiça em Bonn ou, no caso da associação ser de outro país membro da EU, na comissão europeia. Para ser registrada na Alemanha, as entidades qualificadas devem preencher algumas características, incluindo capacidade legal e a habilidade para promover os interesses do consumidor por meio de informação e aconselhamento). Ver: HENSLER, Deborah R.; HODGES, Christopher; TULIBACKA, Magdalena (et. alli). The Globalization of Class Action...Op. cit., p. 130.

${ }^{371}$ Como discutido, os critérios para aferição da representatividade adequada nos Estados Unidos da América - país onde o conceito floresceu na doutrina e na jurisprudência como requisito para a classificação de uma ação coletiva como Class Action - passam exatamente pela constatação da capacidade intelectual, ideológica e mesmo financeira do legitimado ativo (cf. Capítulo 5, subitem 5.2.1).

${ }^{372}$ Cf. Capítulo 2, subitem 2.2.2.2. 
representativo e, mais do que isso, todos os atos que tenham implicações no direito dos autores devem ser ratificados por todos os demandantes - e.g. o "representante" não tem poderes para transacionar em nome dos demais, a não ser que todos os autores anuam ${ }^{373}$.

\subsubsection{Portugal}

No que toca à positivação da possibilidade ou necessidade de aferição da representatividade adequada no ordenamento jurídico português, vários autores apontam que este se aproximou muito do modelo brasileiro, nada falando sobre a aferição da representatividade dos autores coletivos e sobre a possibilidade do controle jurisdicional desse requisito, mas estabelecendo critérios legais para a verificação da legitimidade especialmente das pessoas jurídicas. Para estas, o artigo $3^{\circ}$ da Lei $n^{\circ}$. 83/1995 prescreve que a instituição deve incluir em seus objetivos estatutários a defesa dos interesses tutelados e, além disso, deixa claro que a entidade não pode exercer nenhum tipo de atividade profissional concorrente com empresas ou profissões liberais ${ }^{374}$.

Quer nos parecer, entretanto, que o ordenamento jurídico português seguiu a mesma linha adotada pela Alemanha nesse tocante. Ou seja, conquanto não traga uma norma expressa atestando que o representante deverá ser adequado - ou que o juiz está autorizado a aferir a representatividade adequada do autor coletivo -, ele conta com diversos dispositivos legais que, analisados em conjunto, denotam essa necessidade e essa possibilidade.

Analisem-se conjuntamente, por exemplo, os artigos 16 e 19 da Lei nº.83/1995. Eles propõem uma espécie de controle da atuação do autor coletivo no caso concreto, prescrevendo que caso ele não se comporte corretamente - ou mesmo aja em conflito de

\footnotetext{
${ }^{373}$ HENSLER, Deborah R.; HODGES, Christopher; TULIBACKA, Magdalena (et. alli). The Globalization of Class Action...Op. cit., p. 131-132.

${ }^{374}$ Entre os doutrinadores que acreditam estar o sistema português muito próximo do brasileiro no que tange à aferição da representatividade adequada encontram-se Humberto Teodoro Junior e Ada Pellegrini Grinover. A autora, em artigo analisando a ação popular portuguesa sob perspectiva comparística, asseverou que: " $E$ certamente a lei portuguesa distanciou-se - como a brasileira - do critério de representatividade adequada das class actions, o qual permite ao juiz aferir caso a caso, em face das suas circunstâncias, a seriedade, a credibilidade, a 'representatividade', enfim, das pessoas físicas e jurídicas amplamente legitimadas pelo sistema, que se façam portadoras, em juízo, dos interesses metaindividuais. [...] o juiz pode indeferir a inicial, mas não pode negar a legitimação - que é exclusivamente determinada por lei - e sim quando entenda ser manifestamente improvável a procedência do pedido, ouvido o Ministério Público e feitas, preliminarmente, as averiguações que o julgador tenha por justificadas ou que o autor ou Ministério Público requeiram (art.13). Trata-se aqui do indeferimento da inicial por ausência do fumus boni iuris, e não da aferição de representatvidade como elemento essencial da legitimação para agir". Ver "A ação popular portuguesa: uma análise comparativa" (GRINOVER, Ada Pellegrini. A marcha do processo. Rio de Janeiro: Forense Universitária, 2000, p. 52).
} 
interesses - estará sujeito à remoção do polo ativo, sendo a ação assumida pelo Ministério Público $^{375}$. O controle desse comportamento do legitimado ativo poderá ser feito pelo juiz - a quem também é conferido o poder de restringir os efeitos da coisa julgada com base em "motivações de cada caso concreto" 376 - e pelo Ministério Público enquanto fiscal da lei.

Assim, permitir ao juiz que restrinja os efeitos da coisa julgada de acordo com as circunstâncias do caso, equivale dizer que o autor não representou adequadamente todos os integrantes da classe - o mesmo acontecendo acaso se determine a substituição do polo ativo em virtude da apuração de comportamentos lesivos para o interesse da causa ${ }^{377}$. Por esse motivo, entende-se que Portugal contempla a possibilidade de aferir - ainda que indiretamente - a representatividade adequada dos autores coletivos ou, ao menos, deixou expresso em sua legislação critérios para que isso possa ser feito.

\subsubsection{Argentina}

No ordenamento jurídico argentino, não constam listados os requisitos para a aferição da representatividade. A doutrina argentina tem se ocupado em afirmar continuamente a necessidade de uma postura ativa dos juízes quanto à apuração da idoneidade do autor e a seriedade da demanda para, só então, aceitar a propositura da ação coletiva. Augusto Mario Morello, por exemplo, pontua que o poder conferido às associações deve ser fiscalizado de perto, visando coibir a apropriação por essas entidades de competências que seriam do Estado ${ }^{378}$.

Ainda com relação às associações, é preciso notar que na Argentina existe uma espécie de controle prévio da representatividade, uma vez que é exigido um registro para que a associação seja legitimada à propositura de ações coletivas. Embora a maioria dos diplomas nada diga a respeito da forma como se dá tal registro - e a Constituição argentina fale apenas em "registro na forma da lei" -, a "Ley Nacional de Defensa del Consumidor"

\footnotetext{
375 Artigo 16, no 3 da Lei 83/95. No âmbito da fiscalização da legalidade, o Ministério Público poderá, querendo, substituir-se ao autor em caso de desistência da lide, bem como de transação ou de comportamentos lesivos ao interesse da causa.

${ }^{376}$ Artigo $19, n^{\circ} .1$ da Lei 83/95. As sentenças transitadas em julgado proferidas em acções ou recursos administrativos ou em acções cíveis, salvo quando julgadas improcedentes por insuficiência de provas, ou quando o julgador deva decidir por forma diversa fundado em motivações próprias do caso concreto, têm eficácia geral, não abrangendo, contudo, os titulares dos direitos ou interesses que tiverem exercido o direito de se auto-excluírem da representação.

377 PASCHOAL, Maximilian Fierro. A representatividade adequada nas ações coletivas brasileiras...Op. cit., p. 220.

378 MORELLO, Augusto Mario. La tutela de los intereses difusos en el derecho argentino legitimaciones, medidas cautelares, trámite y efectos del amparo colectivo. Libreria Editora Platense, 1999, p. 75-76.
} 
traz alguns requisitos que a associação deve preencher para pleitear tal autorização (artigos 56 a 58). Alguns deles são: (i) receber reclamações dos consumidores e promover soluções amigáveis; (ii) promover a educação do consumidor; (iii) realizar e organizar estudos de mercado; e (iv) se abster de assumir posições econômicas ou políticas, entre outras. Por meio desses critérios é possível, ao menos em tese, aferir de forma prévia a seriedade e a idoneidade de determinada associação - tal como se observa no ordenamento alemão analisado acima.

A doutrina e a jurisprudência argentina não se fazem refratárias à ideia do controle da representatividade adequada pelo juiz, ainda que careça o ordenamento jurídico de disposição específica a este respeito $^{379}$, e têm ampliado gradativamente essa análise, inserindo na aferição outros critérios que não estão textualmente na lei, mas que permeiam o ordenamento jurídico (como a necessidade de defender de forma idônea os interesses da classe representada).

\subsection{PROPOSTAS PARA POSITIVAÇÃO DA REPRESENTATIVIDADE ADEQUADA NO ORDENAMENTO JURÍDICO BRASILEIRO}

Este estudo já passou pela análise da formação do microssistema dos processos coletivos no Brasil, pelo conceito de representatividade adequada e pela forma como os ordenamentos jurídicos de alguns países de Common Law e Civil Law contemplam esse requisito. Tudo isso se fez com o objetivo de verificar a importância da representatividade adequada na sistemática da tutela dos interesses transindividuais, como requisito fundamental para a garantia do devido processo legal, o que servirá de base para verificar a possibilidade do controle jurisdicional da atuação do legitimado ativo nas ações coletivas no país.

\footnotetext{
${ }^{379}$ Ao escrever sobre o tema, Marcelo José Magalhães Bonício entendeu que o dispositivo 661 do "Código Procesal Civil, Comercial, Laboral, Rural y Minero" da província da Tierra del Fuego, ao preconizar que o juiz examinará a demanda e resolverá acerca de sua viabilidade, estaria falando de um requisito de representatividade. Esse entendimento, no entanto, expande indevidamente o quanto disposto no texto legal. A referida norma faz referência ao escrutínio das condições da ação, de forma geral, mas não especifica a necessidade ou a possibilidade de se aferir a representatividade adequada, in verbis: Admisibilidad. Finalizado el plazo del artículo anterior, y previa vista fiscal, el Juez examinará la demanda y resolverá acerca de la viabilidad de la misma para desestimarla in limine o darle el curso que correspondiere. Sobre o tema, ver BONÍCIO, Marcelo José Magalhães. Breve análise comparativa entre a tutela dos interesses difusos no direito argentino e no direito brasileiro. Mundo Jurídico, 2005. Disponível em http://www.mundojuridico.adv.br/sis_artigos/artigos.asp?codigo=271. Acessado em 27dez.2012.
} 
Antes disso, porém, ante a evidente importância do conceito, caberá verificar as tentativas dos estudiosos brasileiros sobre o tema de positivar a necessidade de aferição da representatividade adequada e também os parâmetros para a realização dessa análise pelos juízes. Não foram poucas as propostas mas, até o momento, todas foram rechaçadas pelo poder legislativo.

A primeira tentativa data ainda da época em que a legislação acerca dos processos coletivos era incipiente e se limitava à Lei de Ação Popular (1965) e à Lei da Política Nacional do Meio Ambiente (1981). Surgidos os primeiros movimentos para a positivação da Lei da Ação Civil Pública, foi apresentado um projeto por Ada Pellegrini Grinover, Kazuo Watanabe, Cândido Rangel Dinamarco e Waldemar Mariz de Oliveira Junior. Tal projeto, que ficou conhecido como "Projeto de Lei Flávio Bierrenbach", contemplava entre seus artigos o controle da representatividade adequada pelos juízes. Nesse particular, entretanto, o texto final da Lei $\mathrm{n}^{\mathrm{o}} 7.347 / 1985$ acolheu o substitutivo proposto pelo Ministério Público de São Paulo, que optava por listar os legitimados para a propositura das ações coletivas sem mencionar a possibilidade de aferição da adequação do representante - texto que vigora até hoje sem grandes alterações quanto ao tema. Essa orientação foi repetida pela Constituição Federal de 1988 e pelo Código de Defesa do Consumidor em $1990^{380}$.

Ao longo das últimas três décadas, desde a positivação da Lei da Ação Civil Pública, passando pela entrada em vigor de diversos outros diplomas legais que traziam regras sobre processos coletivos, sentiu-se a premente necessidade de uma sistematização dos dispositivos que regulamentam a tutela dos interesses transindividuais. Esses debates resultaram no Anteprojeto para o Código Brasileiro de Processos Coletivos.

Até o ano de 2007, algumas propostas para um Código Brasileiro de Processos Coletivos foram apresentados por diferentes grupos de estudiosos, mas com o objetivo comum de reunir e sistematizar em um mesmo diploma legal toda a legislação sobre direitos da coletividade, bem como os meios para tutela desses interesses ${ }^{381}$. Dentre eles serão analisados aqui o anteprojeto foi gestado no curso de pós-graduação da Faculdade de Direito da Universidade de São Paulo em 2003 (“Anteprojeto USP”), sob as coordenações

\footnotetext{
${ }^{380}$ GRINOVER, Ada Pellegrini (et alli). Código Brasileiro de Defesa do Consumidor comentado pelos autores do anteprojeto. V. II. 10. ed. Rio de Janeiro: Forense, 2011, p. 97-98.

${ }^{381}$ Aponta o professor Arruda Alvim a existência dos seguintes anteprojetos: " $1^{\circ}$ ) pelo Prof. Antonio Gidi; $2^{\circ}$ ) pelo instituto Ibero-americano de Direito Processual Civil; $3^{\circ}$ ) pela UERJ/UNESA; $4^{\circ}$ ) pelo mestrado da USP (Profs. Ada Pellegrini Grinover e Kazuo Watanabe; $5^{\circ}$ ) pelo Instituto Brasileiro de Direito Processual" (ARRUDA ALVIM, José Manoel de. Perspectivas de alterações do sistema coletivo de ações no Brasil. Revista Forense, v. 399, Rio de Janeiro:2008, p. 28).
} 
de Ada Pellegrini Grinover e Kazuo Watanabe, e anteprojeto elaborado no ano de 2005 pelos alunos do curso de pós-graduação da Universidade Estadual do Rio de Janeiro e da Universidade Estácio de Sá (“Anteprojeto UERJ/UNESA”), orientados pelo professor Aluísio Gonçalves de Castro Mendes.

Apesar de ter existido, à época, intensa colaboração entre os dois grupos que idealizaram os citados projetos, dois textos de anteprojeto diversos resultaram desses estudos - o Anteprojeto UERJ/UNESA originou-se da colaboração dessas faculdades ao projeto inicialmente elaborado pela Universidade de São Paulo. O "Anteprojeto USP", depois de encampar as alterações sugeridas pelos estudiosos do Rio de Janeiro, foi assumido pelo Instituto Brasileiro de Direito Processual (IBDP) e por ele apresentado ao Congresso Nacional no ano de $2007^{382}$.

Tais projetos são o saldo dos esforços daqueles que se dedicam ao estudo dos direitos transindividuais, buscando a solução de problemas surgidos na aplicação do microssistema de processos coletivos que, ainda hoje, é formado por diversos dispositivos espalhados em pelo menos quatro diplomas legais diferentes - Constituição Federal, Lei da Ação Civil Pública, Código de Defesa do Consumidor e Lei do Mandado de Segurança $\left(\text { Lei } \mathrm{n}^{\mathrm{o}} 12.016 / 2009\right)^{383}$. Os autores dos anteprojetos reconhecem que a tônica das propostas legislativas passam, primordialmente, pelo aperfeiçoamento das técnicas existentes, aliadas à flexibilização da técnica processual - ainda muito marcada pela influência individualista - , bem como pelo aumento dos poderes do juiz ${ }^{384}$. E, neste

\footnotetext{
${ }^{382}$ Como coloca a professora Ada Pellegrini Grinover na exposição de motivos do Código Brasileiro de Processos Coletivos: "O Código Modelo foi profundamente analisado e debatido no Brasil, no final de 2.003, ao ensejo do encerramento do curso de pós-graduação stricto sensu da Faculdade de Direito da Universidade de São Paulo, por professores e pós-graduandos da disciplina 'Processos Coletivos', ministrada em dois semestres por Ada Pellegrini Grinover e Kazuo Watanabe, para verificar como e onde suas normas poderiam ser incorporadas, com vantagem, pela legislação brasileira. E daí surgiu a idéia da elaboração de um Código Brasileiro de Processos Coletivos, que aperfeiçoasse o sistema, sem desfigurá-lo. Ada Pellegrini Grinover coordenou os trabalhos do grupo de pós-graduandos de 2.003 que se dispôs a preparar propostas de Código Brasileiro de Processos Coletivos, progressivamente trabalhadas e melhoradas. [...] O Instituto Brasileiro de Direito Processual, por intermédio de seus membros, ofereceu diversas sugestões. No segundo semestre de 2.005, o texto foi analisado por grupos de mestrandos da UERJ e da Universidade Estácio de Sá, sob a orientação de Aluísio de Castro Mendes, daí surgindo mais sugestões. O IDEC também foi ouvido e aportou sua contribuição ao aperfeiçoamento do Anteprojeto". Disponível em http://www.mpcon.org.br/site/portal/jurisprudencias_detalhe.asp?campo=2897. Acessado em 15out.2012. Nesse sentido, ver também "O anteprojeto de código Brasileiro de Processos Coletivos: visão geral e pontos sensíveis" (MENDES, Aluísio Gonçalves de Castro. In: Ada Pellegrini Grinover (et. alli). Direito Processual Coletivo e o anteprojeto de código brasileiro de processos coletivos. São Paulo: Ed. RT 2007, p. 17).

${ }_{383}$ A nova lei do mandado de segurança (Lei $\mathrm{n}^{\circ}$ 10.016/2009) disciplina também o mandado de segurança coletivo, antes previsto apenas pela Constituição Federal.

${ }^{384}$ GRINOVER, Ada Pellegrini. Exposição de motivos do anteprojeto do Código Brasileiro de Processos Coletivos. Associação Nacional do Ministério Público do Consumidor, 2007. Disponível em
} 
contexto, ambos os projetos anotaram a necessidade de aferição da representatividade adequada pelo juiz, em cada caso concreto.

A representatividade adequada é trazida pelos dois projetos como princípio da tutela jurisdicional coletiva ${ }^{385}$, nos dois textos é conferido ao juiz o poder e o dever de analisar, a qualquer tempo e em qualquer grau de jurisdição, a atuação do representante. A diferença crucial entre os anteprojetos, no entanto, está na abrangência dessa aferição.

Isso porque enquanto o "Anteprojeto UERJ/UNESA" optou por positivar a necessidade de comprovação da representatividade adequada e, consequentemente, a possibilidade de controle ope judicis do requisito, como base para a atribuição de legitimidade para todos os colegitimados ativos ${ }^{386}$, o "Anteprojeto USP", por sua vez, limitou-se a exigir a representatividade adequada do indivíduo, quando este pretender atuar em nome do grupo ${ }^{387}$. Desta forma, o "Anteprojeto USP", posteriormente apresentado ao Congresso pelo Instituto Brasileiro de Direito Processual, deixou de resolver os questionamentos com relação à possibilidade de controle judicial da representatividade adequada dos demais autores coletivos - notadamente das associações, que são tema desta dissertação - porquanto tenha apenas condicionado a legitimação da pessoa física ao preenchimento do requisito.

No tocante às associações, o “Anteprojeto USP” limitou-se a especificar algo que, atualmente, já está positivado em nosso ordenamento jurídico, no sentido de que poderá ser dispensado pelo juiz o requisito da pré-constituição há um ano se entender que as características do dano, a relevância jurídica do direito pleiteado ou a inequívoca representatividade adequada assim o autorizam ${ }^{388}$. A representatividade adequada, nesse

http://www.mpcon.org.br/site/portal/jurisprudencias_detalhe.asp?campo=2897. Consultado em 28.jun 2011; e "Superação do modelo processual rígido pelo anteprojeto do Código Brasileiro de Processos Coletivos, à luz da atividade gerencial do juiz" (LUCON, Paulo Henrique dos Santos; GABBAY, Daniela Monteiro. In: Ada Pellegrini Grinover (et. alli). Direito Processual Coletivo e o anteprojeto de código brasileiro de processos coletivos. São Paulo: Ed. RT, 2007.

${ }^{385}$ Artigo $2^{\circ}$, "l", do anteprojeto USP e $8^{\circ}$, I, do anteprojeto UERJ/UNESA.

386 Art. $8^{\circ}$. Requisitos específicos da ação coletiva: São requisitos específicos da ação coletiva, a serem aferidos em decisão especificamente motivada pelo juiz: I - a adequada representatividade do legitimado;§ $2^{\circ}$. O juiz analisará a existência do requisito da representatividade adequada a qualquer tempo e em qualquer grau do procedimento, aplicando, se for o caso, o disposto no parágrafo $3^{\circ}$. do artigo seguinte.

387 Art. 20. Legitimação. São legitimados concorrentemente à ação coletiva ativa: I - qualquer pessoa física, para a defesa dos interesses ou direitos difusos, desde que o juiz reconheça sua representatividade adequada [...]; II - o membro do grupo, categoria ou classe, para a defesa dos interesses ou direitos coletivos, e individuais homogêneos, desde que o juiz reconheça sua representatividade adequada, nos termos do inciso I deste artigo.

${ }^{388}$ Artigo 20. $\S 4^{\circ}$ Em relação às associações civis e às fundações de direito privado, o juiz poderá dispensar o requisito da pré-constituição, quando haja manifesto interesse social evidenciado pelas características do 
contexto, assume um caráter subsidiário - que se presta apenas a suprir o requisito da préconstituição há um ano da entidade associativa. Se viesse a entrar em vigor com esse texto, o “Anteprojeto USP” não apaziguaria os questionamentos acerca da possibilidade do juiz negar a legitimidade às associações cuja atuação se verifique inidônea ou que não defendam com o vigor e conhecimento necessários os interesses declinados em seu estatuto.

Por esse motivo, e também por acreditar que a representatividade adequada é consectária do devido processo legal nos processos coletivos - devendo pautar a atuação de todos os legitimados -, acredita-se que o modelo apresentado pelo "anteprojeto UERJ/UNESA" é o que veicula da melhor forma o texto legal que colocaria fim às polêmicas quanto à possibilidade da aferição da representatividade adequada, já que não é possível presumir a boa e efetiva atuação de todos os legitimados em todos os cenários possíveis da vida - ainda que se guarde respeito às instituições eleitas pelo legislador e sua atuação em prol da sociedade.

Entretanto, no que diz respeito às características que preenchem de significado o conceito da representatividade adequada, os dois anteprojetos se alinharam ao prever que é considerado adequado o representante que: (i) tenha credibilidade, capacidade e experiência; (ii) tenha histórico de proteção judicial e extrajudicial dos interesses ou direitos dos membros do grupo, categoria ou classe; e (iii) tenha apresentado conduta irrepreensível em outros processos coletivos ${ }^{389}$. O "anteprojeto UERJ/UNESA" acrescenta ainda, neste rol, os requisitos que hoje estão positivados para a atribuição de legitimidade às associações: a coincidência entre os objetivos dos legitimados e o objeto da demanda o que se prestaria a preencher o requisito que hoje se conhece por pertinência temática - e o tempo de constituição da entidade.

Observa-se, pois, que os anteprojetos, conquanto tenham dado maior ou menor liberdade ao juiz no momento de aferir a representatividade adequada dos legitimados ativos, estabeleceram parâmetros para que essa verificação possa ser realizada. Esses parâmetros tomam como base o que foi fixado pela jurisprudência norte-americana e, ainda, com o que foi discutido pelos representantes de diversos países que adotam o

dano, pela relevância do bem jurídico a ser protegido ou pelo reconhecimento de representatividade adequada (inciso I deste artigo).

${ }^{389}$ Artigo 20, I, "a", "b" e "c", do "anteprojeto USP" e artigo $8^{\circ}, \S 1$, do "anteprojeto UERJ/UNESA". 
sistema de Civil Law acerca do tema, e acabaram sendo positivados no Código Modelo dos Processos Coletivos para a Ibero-América ${ }^{390}$.

Tais anteprojetos, no entanto, não foram aprovados. O país continuou carente de uma lei que sistematizasse a tutela dos interesses transindividuais. Por conta disso, no ano de 2009, foi proposto novo projeto de lei ( $\mathrm{PL} \mathrm{n}^{\circ} 5.139 / 2009$ ), agora para reformar a Lei da Ação Civil Pública (Lei no 7.347/1985). A rigor, tratou-se de uma abordagem diversa para o mesmo problema, já que o texto do projeto de lei em questão reavivara uma série de propostas veiculadas anteriormente nos anteprojetos para o Código de Processos Coletivos. Desta forma, toda a matéria referente aos processos coletivos passaria a ser estabelecida nesta lei.

O Projeto de Lei 5.139/2009, no entanto, adotou basicamente os mesmos esquemas de legitimação hoje positivados em nosso ordenamento jurídico - tendo incluído expressamente algumas entidades como a Ordem dos Advogados do Brasil e outras entidades de classe, sindicatos e partidos políticos. Não previu, entretanto, a possibilidade de aferição da representatividade adequada pelos juízes, nem como pressuposto para a atribuição de legitimidade (como feito anteriormente pelo “Anteprojeto USP”), nem como princípio da tutela coletiva (como feito pelo "Anteprojeto UERJ/UNESA"). Tivesse sido aprovado, o projeto de lei deixaria também em aberto a questão da possibilidade de aferição ope judicis da representatividade adequada e seus parâmetros.

Tal projeto de lei, entretanto, também foi rechaçado ainda na Câmara, sob a justificativa de que criaria um tratamento desigual entre as partes, privilegiando de forma desmesurada os autores em detrimento dos réus. Importa citar a menção feita pelo deputado José Carlos Aleluia, que proferiu o voto vencedor - pela rejeição do projeto de lei - quanto à ausência de previsão ou requisitos do que seria um bom representante da coletividade:

\footnotetext{
${ }^{390} \mathrm{O}$ artigo $2^{\mathrm{o}}$ do Código Modelo de Processos Coletivos para Ibero-América, na realidade, tem o mesmo texto adotado pelo "anteprojeto UERJ/UNESA" no que toca à aferição da representatividade adequada. A discussão de todos os projetos se deu no mesmo espaço de tempo e, uma vez que foram propostos e discutidos por um grupo de estudiosos muito semelhante, adotaram-se textos parecidos para institutos análogos. Sobre a representatividade adequada, a exposição de motivos do Código Modelo de Processos Coletivos para Ibero-América, elaborada por Roberto Berizonce (Argentina), Ada Pellegrini Grinover (Brasil) e Angel Landoni Sosa (Uruguai), diz o seguinte: "O Código Modelo de Processos Coletivos para Ibéro-américa recepcionou a idéia brasileira da tutela dos interesses difusos, com algumas modificações em relação à legitimação (que inclui qualquer interessado) e ao controle da representatividade adequada (que no Brasil não é expresso). [...] A representatividade adequada - mencionada em muitos estatutos iberoamericanos - é exigida e detalhada, mediante uma lista exemplificativa de critérios que poderão orientar o juiz em sua avaliação." Disponível em http://www.pucsp.br/tutelacoletiva/download/ codigomodelo_exposicaodemotivos_2_28_2_2005.pdf. Acessado em: 27dez.2012.
} 
O autor não corre risco algum ao mover a ação: não paga custas, não paga pela prova a ser feita no curso da ação nem paga honorários, se vencido. Mais: praticamente quaisquer duas pessoas podem ir a juízo, apresentarem-se como representantes de um grupo ou até mesmo de toda a sociedade brasileira e pedirem, por exemplo, a paralização de uma iniciativa do poder público por ofensa ao meio-ambiente. Não há requisitos para que alguém se apresente em juízo como representante de uma classe. Basta formalizar parcamente uma associação e defender, perante um juiz parcial e complacente, que sua causa é relevante ${ }^{391}$.

No ano de 2012 foi proposta ao Senado Federal uma série de alterações em artigos do Código de Defesa do Consumidor, contemplando assuntos que não eram sequer discutidos à época da entrada em vigor desse diploma legal e, atualmente, passaram a ser alvo de grande preocupação da sociedade ${ }^{392}$. Entre eles estão as regras visando regulamentar de forma mais específica o comércio eletrônico e outras com o objetivo de amparar o consumidor frente à possibilidade de superendividamento - isso no que se refere às proposições relativas a direito material. No campo procedimental, notadamente das ações coletivas previstas pelo Código de Defesa do Consumidor, o projeto de lei para alterar o diploma consumerista apresentado propõe uma série de modificações - entre elas a previsão de um procedimento conciliatório, a criação de um cadastro nacional de processos coletivos, entre outros. Não traz nenhuma proposta de alteração no rol de legitimados para a propositura de ações em defesa dos interesses da coletividade. Propõe, no entanto, critérios objetivos para a fixação dos honorários das associações civis, acrescendo a estes honorários uma verba de compensação a ser suportada pelo réu, no caso de procedência de demanda coletiva que tenha relevante interesse público envolvido ${ }^{393}$.

Ao alterar o cenário atual e prever expressamente o pagamento de honorários às associações, fixando um regime próprio para tanto - ampliando, inclusive, as verbas a que o réu poderá ser condenado a pagar ao autor coletivo -, e não trazendo nenhum dispositivo que permita a aferição da representatividade adequada dos legitimados, acredita-se que o

\footnotetext{
${ }^{391}$ Trecho do voto do deputado relator José Carlos Aleluia perante a Comissão de Constituição e Justiça e de Cidadania, pela rejeição do projeto de lei nº 5.139/2009. Disponível em http://www.camara.gov.br/proposicoesWeb/prop_mostrarintegra;jsessionid=BF3B6339770A1552CD90D32 EF1E7AB1C.node2?codteor=754582\&filename=Parecer-CCJC-17-03-2010. Consultado em 15.out.2012.

${ }^{392}$ Anteprojeto disponível em http://www.senado.gov.br/senado/codconsumidor/pdf/ Anteprojetos_finais_14_mar.pdf,consultado em 15 out.2012.

393 O artigo 87 do referido Código ganharia parágrafos e incisos prevendo as regras para o pagamento de honorários às associações civis autoras de processos coletivos, em caso de procedência da demanda. Maior interesse se foca no $\S 3^{\circ}$ que seria acrescido ao artigo para determinar que: "Na hipótese de relevante interesse público, direta ou indiretamente satisfeito pela demanda movida pela associação, o juiz, sem prejuízo da verba da sucumbência, poderá fixar compensação financeira, suportada pelo réu, observados os critérios de razoabilidade e proporcionalidade".
} 
projeto em questão resvale no mesmo problema do seu antecessor, o projeto de lei 5.139/2009. Isso porque mais uma vez se está dando uma desmedida vantagem aos autores em detrimento dos réus - que novamente estarão sujeitos a todos os ônus econômicos do processo, sem terem qualquer garantia acerca da idoneidade do autor. Garantia esta que se presta, em primeiro plano, a proteger os substituídos processualmente, ou seja, a coletividade, mas, certamente, também tem uma faceta de proteção da contraparte no processo.

Desta feita, até o presente momento, as tentativas de positivação da representatividade adequada no ordenamento jurídico brasileiro foram frustradas, e o projeto que hoje tramita no Senado Federal não contemplou expressamente a possibilidade de controle do requisito pelos juízes. Permanece, portanto, viva a discussão que ora se aborda: podem os juízes aferir a representatividade adequada dos legitimados ativos - em especial das associações - mesmo que sem a existência de previsão expressa nesse sentido? O próximo capítulo enfrentará e procurará responder a este questionamento. 


\section{CONTROLE OPE JUDICIS DA REPRESENTATIVIDADE ADEQUADA DAS ASSOCIAÇÕES}

Neste capítulo será analisada a possibilidade dos juízes brasileiros aferirem a representatividade adequada das associações que propõem ações em defesa dos direitos transindividuais, independentemente de expressa previsão legal determinando que tal análise seja feita.

O estudo não se limitará a expor os motivos pelos quais se acredita ser possível e desejável o controle da representatividade adequada das associações, mas pretende analisar dispositivos constantes do ordenamento jurídico brasileiro que, interpretados de forma conjunta e condizente com os objetivos constitucionais do processo coletivo, possam servir de parâmetro para tal aferição.

Seguindo as premissas teóricas e conceituais delineadas nos capítulos anteriores, entende-se, desde logo, que essa aferição é possível e necessária - seja para assegurar a plena consecução dos ditames constitucionais no processo coletivo, garantindo a plena concretização do princípio do devido processo legal, seja para evitar o abuso de direito, mantendo a boa-fé que deve permear todas as relações jurídicas.

\subsection{POSSIBILIDADE E NECESSIDADE DO CONTROLE JURISDICIONAL DA REPRESENTATIVIDADE ADEQUADA}

\subsubsection{A representatividade adequada como forma de garantir a efetivação dos direitos e garantias previstos pela constituição brasileira}

O direito constitucional é o primeiro, tanto na ordem topológica, quanto na ordem lógica, dos ramos do direito ${ }^{394}$ - regendo, em última análise, as relações jurídicas de direito público e, também, as de direito privado. Tendo sido reconhecido, desde o direito romano, escopo e orientação eminentemente publicistas do processo civil - acentuando-se que a relação jurídica processual tem sempre, em um de seus polos, o próprio Estado no exercício de função jurisdicional -, é inevitável se remeter à Constituição como fonte dos

\footnotetext{
${ }^{394}$ GRINOVER, Ada Pellegrini. As Garantias Constitucionais do Direito de Ação. São Paulo: RT, 1973, p.7.
} 
princípios gerais que informam todo o direito processual ${ }^{395}$. Isso porque, como destaca Liebman:

\begin{abstract}
O direito processual, em qualquer de seus ramos (civil, penal, administrativo, tributário), disciplina uma atividade que se situa no ponto de encontro de problemas fundamentais da sociedade e do Estado: trata-se da atividade consistente em fazer justiça e assegurar a integridade e a vitalidade da ordem jurídica, concorrendo assim para definir e assegurar a personalidade dos indivíduos em suas relações recíprocas e perante o poder social, na medida em que lhes oferece meios jurídicos para a defesa de seus direitos e interesses e da sua liberdade ${ }^{396}$.
\end{abstract}

Reforça essa premissa ao ressaltar que o processo só se preenche de total significado ao ser estudado sob os auspícios do direito constitucional,

[...] portador do indispensável aparato de garantias e modos de exercício da promessa de justiça contida na Constituição para a defesa dos direitos fundamentais do homem, no rigor da necessária disciplina de uma função pública $^{397}$.

Nesse sentido, o estudo do processo civil em conjunto com as orientações constitucionais seria o caminho para transformar o processo de simples instrumento de justiça em garantia de liberdade - assumindo um raciocínio próprio da ideologia liberal e, primordialmente, voltado ao processo individual. No entanto, com muito mais razão, tal visão deve ser aplicada ao âmbito dos processos coletivos.

Nesse tipo de processo, não apenas o valor liberdade, apontado pelo estudioso italiano - próprio da primeira geração de direitos fundamentais - está em jogo. Os processos que objetivam a tutela jurisdicional de interesses transindividuais trazem a juízo também os direitos fundamentais de segunda e terceira gerações - os direitos sociais e os direitos de solidariedade, respectivamente - e veiculam pretensões que exigem mais do que a garantia da igualdade jurídica, cobrando que se possibilite às partes também as igualdades técnica e econômica, ou, ao menos, que se mitigue a vulnerabilidade de uma das $\operatorname{partes}^{398}$.

Assim sendo, é forçoso reconhecer que as discussões que cercam a matéria dos processos coletivos vêm carregadas de questões constitucionais, desde os direitos que serão

\footnotetext{
${ }^{395}$ Ibid., p. 11-13.

${ }^{396}$ LIEBMAN, Enrico Tullio. Manual de Direito Processual Civil. vol 1. 3. ed. São Paulo: Malheiros, 2005 , p. 58.

${ }^{397}$ Ibid., p. 59.

${ }^{398}$ CAPELLETTI, Mauro. Processo, Ideologia e Sociedade. Vol. I. Tradução e notas de Elício de Cresci Sobrinho. Porto Alegre: Sérgio Antonio Fabris Ed., 2008, p. 379-382.
} 
defendidos por essa via - cuja dispersão e importância social justificam sua tutela coletiva - até as adaptações pelas quais devem passar os institutos processuais clássicos para possibilitar efetiva proteção desses interesses.

No que se refere pois, à defesa dos interesses transindividuais, como anteriormente se destacou, está a legitimidade ativa atribuída a determinadas entidades visando à defesa dos direitos de toda uma coletividade que, mesmo não sendo parte da relação jurídica processual, será atingida pelos efeitos da coisa julgada coletiva - nisso consistindo uma das grandes vantagens do processo coletivo: a possibilidade de atingir um grande número de pessoas sem a necessidade do ajuizamento de diversas demandas individuais, tampouco a inconveniência da formação de litisconsórcio unitário ${ }^{399}$. De outra banda, há que se assegurar que esses ausentes, que terão sua esfera jurídica afetada pela decisão na ação coletiva, sejam defendidos de forma igual ou melhor do que se eles próprios estivessem em juízo.

E isso seria decorrência lógica das garantias e princípios constitucionais sobre os quais se assenta o processo civil brasileiro, destacando-se a garantia ao devido processo legal (artigo $5^{\circ}$, LIV da Constituição Federal de 88$)^{400}$, que se consubstancia no princípio do pleno e efetivo contraditório e na possibilidade da ampla defesa dos litigantes nos processos judiciais e administrativos (artigo $5^{\circ}, \mathrm{LV}$ da Constituição Federal de 88$)^{401}$. Esses princípios e garantias, em última análise, estão ligados ao direito inviolável à segurança - previsto no caput do artigo $5^{\circ}$ e em diversos outros dispositivos da Constituição - que, em sua vertente da "segurança jurídica", por sua vez, está ligado à própria ideia de realização da justiça ${ }^{402}$.

\footnotetext{
${ }^{399}$ Conforme discutido no primeiro capítulo deste estudo, as ações coletivas foram desenvolvidas justamente para lidar com os casos que a necessidade de formação do litisconsórcio (que, de acordo com as regras da Inglaterra do início do século XII, era obrigatório) inviabilizava a judicialização do conflito.

${ }^{400} \mathrm{LIV}$ - ninguém será privado da liberdade ou de seus bens sem o devido processo legal;

${ }^{401} \mathrm{LV}$ - aos litigantes, em processo judicial ou administrativo, e aos acusados em geral são assegurados o contraditório e ampla defesa, com os meios e recursos a ela inerentes;

${ }^{402}$ Como assinala José Afonso da Silva, "[...] o caput do artigo $5^{\circ}$ fala em 'inviolabilidade do direito à segurança', o que, no entanto, não impede que seja ele considerado um conjunto de garantias - natureza que, aliás, se acha ínsita no termo 'segurança'. Efetivamente, esse conjunto de direitos aparelha situações, proibições, limitações e procedimentos destinados a assegurar o exercício e o gozo de algum direito fundamental (intimidade, liberdade pessoal ou incolumidade física ou moral): segurança das relações jurídicas (Art. $5^{\circ}, \mathrm{XXXVI)}$, segurança do domicílio (artigo $5^{\circ}$, XI), segurança das comunicações pessoais (artigo $5^{\circ}, \mathrm{IV}$ ) e segurança em matéria penal e processual penal (art. $5^{\circ}$, XXXVII - XLVII)", ver: SILVA, José Afonso da. Comentário Contextual à Constituição. 3.ed. Malheiros: São Paulo, 2007, p. 72. Em outras palavras, a garantia desse direito fundamental à segurança, em sua vertente da segurança jurídica, pode ser observada em outros dispositivos constitucionais, a exemplo da coisa julgada, respeito aos direitos adquiridos, respeito ao ato jurídico perfeito, prévia lei para a configuração de crimes e transgressões e cominação de penas, independência do Poder Judiciário, vedação de tribunais de exceção.
} 
Cabe discorrer brevemente sobre essas garantias, para verificar de que forma a aferição da representatividade adequada dos legitimados ativos, pelos juízes brasileiros, nos processos coletivos, pode assegurar a efetivação de cada uma dessas garantias e, por conseguinte, dos direitos fundamentais.

A garantia constitucional do contraditório é a que se relaciona de forma mais profunda com o tema da representatividade adequada nas ações coletivas brasileiras, significa, nas palavras de Cândido Rangel Dinamarco, que "[...] a lei deve instituir meios para a participação dos litigantes no processo e o juiz deve franquear-lhes esses meios. (...) A garantia deste resolve-se, portanto, em um direito das partes e uma série de deveres do juiz" ${ }^{, 403}$.

O processo, conforme ressaltado acima, não pode ser visto como um meio para que as partes resolvam suas controvérsias - não se limitando, pois, a uma perspectiva unicamente privatista. Se assim fosse, os atos que informam o processo poderiam ser equiparados aos atos de vontade - tais quais os negócios jurídicos - cuja força vinculante está calcada na vontade manifestada livremente pelas partes ${ }^{404}$. A relação jurídica processual, no entanto, tem como escopo o exercício da função jurisdicional, o que transforma o processo em um veículo para a efetivação da justiça.

Os atos processuais, em especial aqueles que emanam da autoridade jurisdicional o juiz -, tal como os atos praticados pelo poder legislativo e executivo, devem ser vistos como atos de poder. Tais atos, quando praticados pelos integrantes do poder legislativo e executivo, no entanto, retiram a legitimidade dos poderes conferidos pelo povo aos integrantes dos cargos que os compõem, por meio da eleição de seus representantes, como ocorre nos regimes democráticos de uma forma geral. Os juízes, por sua vez, não ocupam cargo eletivo de acordo com nosso sistema jurídico, de modo que a legitimação dos seus atos - em especial das decisões prolatadas nos processos que conduzem - deve ser retirada de outra fonte ${ }^{405}$.

${ }^{403}$ DINAMARCO, Cândido Rangel. Instituições de Direito Processual Civil. 5.ed. São Paulo: Malheiros, 2005, p. 234. Tal ideia se coaduna com o raciocínio desenvolvido por Ada Pellegrini Grinover de que "[...] a relação jurídica que se forma no processo é autônoma, diversa da de direito material: seus sujeitos são o juiz, o autor e o réu, em uma relação de natureza triangular" (GRINOVER, Ada Pellegrini. As Garantias Constitucionais do Direito de Ação. São Paulo: RT, 1973, p.11). No mesmo sentido, ver MELLO, Marcos Bernardes. Teoria do Fato Jurídico - plano da eficácia. 2.ed. São Paulo: Saraiva, 2004, p.245-246.

${ }^{404}$ DINAMARCO, Cândido Rangel. Instituições de Direito Processual Civil...Op. cit., p. 234-235.

${ }^{405}$ Conquanto exista uma série de teorias acerca da legitimação dos atos de poder, escolhe-se aqui referir-se à teoria de Niklas Luhmann, que desenvolveu a teoria da legitimação pelo procedimento, uma vez que foi ela que deu esteio ao raciocínio do professor Cândido Rangel Dinamarco. Tais teorias não serão esmiuçadas aqui por estarem além do escopo desta dissertação. Para Luhmann, a legitimação de uma estrutura jurídica - 
Nas lições de Cândido Rangel Dinamarco, no entanto, a participação efetiva no processo, franqueada aos litigantes - como aqueles que têm interesse na resolução da controvérsia e terão suas esferas jurídicas atingidas pela decisão -, tanto nos processos judiciais quanto nos administrativos, é o que legitima tais atos de poder. O deslocamento da participação efetiva para o ponto central da legitimação, em detrimento do procedimento em si, coaduna-se com as ideias de instrumentalidade do processo e do abandono às formas estanques do ponto de vista procedimental. Assim, a força vinculante dos atos de poder - entre eles as decisões prolatadas no curso do processo - advém da participação ativa dos possíveis afetados pelo comando jurisdicional de acordo com regras previamente estabelecidas.

Em outras palavras, é possível dizer que, em última instância, uma sentença somente será legítima se tiver sido garantida a adequada e efetiva participação dos sujeitos que terão suas esferas jurídicas afetadas, ou se a sentença for prolatada em um processo informado pelo efetivo contraditório e pela ampla defesa ${ }^{406}$. Bem por isso, sustenta-se que o efetivo contraditório não é apenas uma garantia das partes, mas, também, da jurisdição como um todo. Nesse sentido, Ada Pellegrini Grinover:

[...] se, de um lado, é interesse dos litigantes a efetiva e plena possibilidade de sustentarem suas razões, de produzirem suas provas, de influírem concretamente sobre a formação do convencimento do juiz, do outro lado essa efetiva e plena possibilidade constitui a própria garantia de regularidade do processo, da imparcialidade do juiz, da justiça das decisões ${ }^{407}$.

Em vista disso, é possível afirmar que o contraditório se efetiva através da certeza de que as partes tenham ciência dos atos praticados no processo e possam a eles reagir, de forma paritária, contrapondo provas e argumentos, com o objetivo de influir na formação

qualquer que seja ela - reside na prontidão para aceitação de suas decisões pela sociedade. Assim, as decisões emanadas pelos poderes do Estado - identificados em sua obra como judiciário, legislativo e administrativo - retirariam a legitimação do procedimento que a elas deu origem. No que toca especificamente à legitimação das decisões prolatadas em processos, o autor expõe que é a adstrição às regras procedimentais que conduz à uma decisão legítima. E, conquanto não negue que a participação das partes seja importante para a legitimação das decisões, a coloca como coadjuvante do protagonismo do procedimento em si. Para ele é o procedimento que evoca a participação das partes e esta contribui para a aceitação da decisão. Ver, sobre o tema LUHMANN, Niklas. Legitimação pelo procedimento. Série Pensamento Político. Brasília: Ed. Universidade Brasiliense, 1980.

${ }^{406}$ DINAMARCO, Cândido Rangel. Instituições de Direito Processual Civil...Op. cit., p. 234-235.

${ }^{407}$ Ver "Defesa, contraditório e par conditio na ótica do processo de estrutura cooperatória" (GRINOVER, Ada Pellegrini. In: O processo constitucional em marcha. Série estudos jurídicos 2. São Paulo: Editora Max Limonad, 1985, p. 15-17. 
da convicção do juiz ${ }^{408}$. O juiz - dentro da concepção de que o contraditório interessa sobremaneira ao Estado -, deixa de ter um papel passivo, de espectador da dinâmica argumentativa e probatória entre as partes, passando a agir para assegurar a igualdade substancial entre os litigantes.

No processo individual, estes últimos serão, ordinariamente, as pessoas que participaram da relação jurídica de direito material que ora se discute em juízo - pois são elas que detêm maior conhecimento dos fatos a alegar e dos meios de prova disponíveis para fundamentar seus pedidos ou sua defesa. Ademais, são estes integrantes da relação jurídica processual que, ao final, sofrerão os reflexos da decisão em suas esferas jurídicas. No mais, como bem pontuado pelo professor Cândido Rangel Dinamarco:

[...] a realidade mostra que o interesse pessoal é sempre a mais eficiente mola da defesa dos direitos e da sua efetividade. Quem vem a juízo postular ou resistir é movido pela aspiração ao bem litigioso, seja para obtê-lo (autor, demandante) seja para manter o status quo ante (réu, demandado) ${ }^{409}$.

O contraditório, portanto, é praticado pelos indivíduos que têm interesse no resultado do processo e que serão os únicos cujas esferas jurídicas serão atingidas pelo provimento jurisdicional. É ele que, analisado em conjunto com a ideia de ampla defesa, garante não apenas que as partes sejam ouvidas em todos os seus argumentos e tenham todas as suas provas devidamente analisadas, mas, também, que disso resultará um provimento jurisdicional justo, legítimo e apto a eliminar os conflitos sociais. Se assim é, como compatibilizar essa ideia com a legitimidade extraordinária, prevista pelas leis que dispõem sobre os processos coletivos?

A ampla defesa, no mesmo sentido, está intimamente ligada ao contraditório tanto da perspectiva topológica - vez que estão previstos no mesmo inciso da Constituição quanto do ponto de vista conceitual, já que não é possível pensar em contraditório efetivo sem uma defesa ampla e integral das partes ${ }^{410}$. Em um primeiro momento, partindo de uma perspectiva histórica, uma nota que diferenciava a ampla defesa do contraditório - e que,

408 NERY JUNIOR, Nelson. Princípios do Processo Civil na Constituição Federal. 3.ed. São Paulo: RT,1996, p.133. Nesse sentido ver, também, “O conteúdo da garantia do contraditório” (GRINOVER, Ada Pellegrini. Novas tendências do direito processual. Rio de Janeiro: Forense Universitária, 1990, p.21). O professor Cândido Rangel Dinamarco resume essa ideia asseverando que o contraditório, a garantia de que as partes efetivamente participarão do processo, depende de lhes oferecer "ao longo de todo o procedimento, oportunidades para participar pedindo, participar alegando e participar provando" (DINAMARCO, Cândido Rangel. Instituições de Direito Processual Civil... Op. cit., p. 235.)

${ }^{409}$ Ibid., p. 235.

${ }^{410}$ SILVA, José Afonso da. Comentário Contextual à Constituição. 3.ed. Malheiros: São Paulo, 2007, p. 73-74. 
portanto, justificava sua previsão de forma autônoma - era o fato de essa estar mais ligada à figura do réu, o qual reage à pretensão autoral e que, portanto, deveria ter acesso a todos os meios de defesa garantidos pela lei para fundamentar essa reação. Atualmente, entretanto, a ampla defesa é entendida de forma mais abrangente, tendente a beneficiar todos os participantes da relação jurídica processual - autor, réus, intervenientes e terceiros interessados -, visando assegurar que todos os meios de defesa disponíveis na legislação, ou ao menos aqueles idôneos, para a defesa de seus interesses lhes sejam facultados ${ }^{411}$.

Partindo dessa definição de contraditório e ampla defesa, é possível dizer que os dois preenchem de conteúdo a garantia constitucional do devido processo legal, que veicula o ideário do processo équo e justo ${ }^{412}$ e atua tanto como uma proteção do indivíduo contra o Estado-persecutor (que, aliás, foi o contexto em que a garantia surgiu, no texto da Magna Carta $^{413}$ ) quanto como uma garantia de paridade de armas com os particulares nos processos entre entes privados.

Bem por isso, a positivação da garantia do devido processo legal e sua consecução são caracteres basilares do Estado Democrático de Direito. Isso porque ela se prestará a assegurar a incolumidade das esferas jurídicas dos indivíduos ${ }^{414}$ - no sentido de que as posições jurídicas de uma só pessoa poderão ser tangenciadas por uma decisão prolatada em processo conduzido e informado segundo essas garantias ou, no mínimo, no âmbito extraprocessual, pelo exercício do autorregramento da vontade ${ }^{415}$. Tanto isso é verdade que a cláusula do devido processo legal somente veio a ser prevista, no Brasil, na Constituição Federal de 1988, muito embora, como anteriormente se assinalou, exista como conceito desde 1215 em outros ordenamentos jurídicos.

Desta feita, pela aplicação das garantias constitucionais ao processo, este somente será justo e équo se for observada a garantia do devido processo legal. Com relação à sentença prolatada em uma determinada ação, ela somente será dotada de legitimação pela participação nos termos explicitados acima - ou, seja, se efetivamente forem observados o

\footnotetext{
${ }^{411}$ Ibid., p. 75.

${ }^{412}$ Sobre o processo équo é justo, assinala o doutrinador italiano Luigi Paolo Comoglio que ele se observa quando cumpridas determinadas garantias - previstas hoje no artigo 111 da Constituição Italiana -, quais sejam: (i) a jurisdição exercida mediante o justo processo regulado pela lei; (ii) o processo informado pelo contraditório entre as partes, em condição de paridade, diante de juiz imparcial; (iii) a duração razoável do processo assegurada pela lei. (COMOGLIO, Luigi Paolo. Etica e Tecnicadel "Giusto Processo"...Op cit.,p. 39-93).

${ }^{413}$ GRINOVER, Ada Pellegrini. As Garantias Constitucionais do Direito de Ação...Op. cit., p. 23-24.

${ }^{414}$ BERNARDES DE MELO, Marcos. Teoria do Fato Jurídico - plano da existência.... Op. cit., p. 217 , 219,220 e 222.

${ }^{415}$ Essas esferas poderão ser afetadas, ainda, por outros atos de poder perpetrados pelo Estado, entre eles a lei - que passa por um processo de legitimação diverso.
} 
contraditório e a ampla defesa. É dessa combinação de fatores que advém um dos grandes desafios do processo coletivo de uma forma geral e, particularmente, no Brasil.

A legislação brasileira atual optou pela atribuição da legitimidade ativa para a propositura de ações coletivas às entidades ligadas ao poder estatal - Ministério Público e Defensoria Pública, por exemplo - e, também, à sociedade civil - como é o caso das associações. Não havendo previsão da legitimidade ativa individual para a defesa dos interesses transindividuais, como ocorre na legislação norte-americana, abriu-se mão da identidade entre o autor da demanda e a titularidade do direito defendido em juízo. Disso decorre que o legitimado ativo não será o beneficiário direto do provimento jurisdicional, tampouco terá sua esfera jurídica diretamente afetada pelo resultado da demanda.

Por esse motivo, o grande problema que os estudiosos das ações coletivas tiveram que enfrentar foi justamente encontrar um modo de equilibrar os benefícios desse tipo de ação, os quais só se consubstanciam se não se fizer necessária a presença de todos os interessados e com a garantia do devido processo legal, este responsável por assegurar que ninguém seja tolhido de seus direitos sem que tenha a oportunidade de se defender adequadamente em juízo ${ }^{416}$.

Para equacionar esse dilema, o legislador e, em alguns casos a jurisprudência, preocupou-se em procurar garantir que a defesa perpetrada pelos legitimados ativos eleitos fosse tão completa e vigorosa quanto aquela praticada pelos próprios titulares do direito que, nesse caso, não participam do processo. É o vigor e o rigor técnico da representação ${ }^{417}$ que terão o condão de assegurar que o contraditório será integral e efetivo, conferindo à sentença coletiva força vinculante, extensível aos terceiros ausentes, nos termos dos artigos 16 da Lei da Ação Civil Pública e 103 do Código de Defesa do Consumidor.

Houve quem defendesse a criação de uma vertente interpretativa da cláusula constitucional do devido processo legal, chegando a se falar em "devido processo legal coletivo" - que decorreria da impossibilidade da aplicação dos princípios constitucionais do contraditório e da ampla defesa de forma ortodoxa ao processo coletivo, devendo esse binômio ser relativizado para que fosse possível acomodar as peculiaridades relativas à tutela dos diretos que emanam dos conflitos da sociedade de massa ${ }^{418}$. Trata-se, no entanto,

\footnotetext{
${ }^{416}$ Sobre o due process of law e a interpretação desse conceito como a garantia de ser ouvido perante $\mathrm{o}$ tribunal ver capítulo 5 deste estudo, subitem 5.2.

${ }^{417}$ Conforme capítulo 5 deste estudo, em que se esmiúça o sentido de representação e de representante adequados no âmbito dos processos coletivos.

${ }^{418}$ MANCUSO, Rodolfo de Camargo. Jurisdição Coletiva e Coisa Julgada. 2. ed. São Paulo: RT, 2007, p. 284.
} 
de uma nova denominação para um problema antigo, para uma preocupação que permeia as ações coletivas desde o seu surgimento - aceitar que os indivíduos titulares dos direitos não participarão diretamente da lide coletiva, mas o farão através de um representante. E, sendo assim, para que essa aplicação diferenciada das garantias constitucionais não implique uma desmedida flexibilização - que importaria em aviltamento dos direitos fundamentais -, esse representante deve atuar em juízo com a mesma qualidade, idoneidade, vigor e seriedade que faria o efetivo titular do direito tutelado. Deve, pois, ser um representante adequado.

Não é outro o motivo pelo qual o instituto da representatividade adequada, desde a sua gênese na Inglaterra medieval, está ligado à efetivação da garantia do due process of law, não sendo admitido que uma decisão em um processo coletivo vincule aqueles que não participaram do processo ou não foram representados adequadamente ${ }^{419}$. Nesse sentido, assevera Owen Fiss sobre as garantias constitucionais e sua relação intrínseca ao instituto aqui estudado:

\begin{abstract}
Acredito que o que a Constituição garante não é o direito de participação, mas o que chamarei de 'direito à representação'; não é 'um dia na corte', mas o direito à representação adequada de interesses. Consoante o direito de representação, nenhum indivíduo pode ser obrigado por uma decisão judicial a menos que seus interesses estejam adequadamente representados no processo. Isso significa que uma decisão estrutural pode ser final se, e somente se, todos os interesses estiverem adequadamente representados no processo. Se um dos interesses envolvidos não estiver representado de forma adequada, a decisão judicial permanece vulnerável a uma nova impugnação; se, entretanto, tal interesse foi completamente representado no processo que conduziu ao proferimento da decisão judicial, a Corte poderá rejeitar liminarmente a nova impugnação, sob o fundamento de que a questão já fora analisada - não obstante o autor da impugnação não tenha participado no processo inicial. ${ }^{420}$
\end{abstract}

No mesmo sentido, também utilizando o termo "devido processo legal coletivo", é a opinião de Antonio Gidi que, ao tratar especificamente do tema da representatividade adequada nas ações coletivas brasileiras, considerou que os direitos de ser citado, ouvido e de apresentar defesa em juízo - direitos estes que consolidam a ideia do devido processo legal - serão exercidos em juízo por meio de um representante, mas não de um

\footnotetext{
${ }^{419}$ No mesmo sentido, manifesta-se Susana Henriques da Costa, ao afirmar que a representatividade adequada é "[...] conceito que torna factível a introdução dos interesses difusos, coletivos e individuais homogêneos em juízo e, ainda, é ele que justifica a prolação de uma decisão com efeitos erga omnes, incidentes sobre terceiros que não foram parte no processo." (O controle judicial da representatividade adequada: uma análise dos sistemas norte-americano e brasileiro. In: Carlos Alberto de Salles (coord.). As grandes transformações do processo civil brasileiro - estudos em homenagem ao professor Kazuo Watanabe. São Paulo: Quartier Latin: 2009, p. 957).

${ }^{420}$ FISS, Owen. Um novo processo civil...Op. cit., p. 215-216.
} 
representante qualquer, um representante reconhecidamente adequado. Isso porque, para esse estudioso, a concepção de representatividade adequada está de tal forma atrelada à legitimidade ad causam nos processos coletivos que não há que se falar de um sem o outro. Não haveria, portanto, representante "inadequado", ele seria, antes, um "não representante" da classe - o que, desde logo, demandaria a extinção do processo sem a resolução do mérito $^{421}$.

Partindo disso, seja para reconhecer a existência de um novo conceito - o de devido processo legal coletivo - ou para defender que se trata de uma interpretação conjuntural da já consagrada garantia constitucional, verifica-se que há uma convergência doutrinária no sentido de reconhecer que apenas por meio da representação adequada dos interesses da coletividade é que se efetiva, no processo coletivo, o devido processo legal - composto, no direito brasileiro, pelos princípios do contraditório e da ampla defesa ${ }^{422}$. Sendo a representatividade adequada um consectário lógico de direitos fundamentais garantidos pela Constituição Federal, parece claro que ela deve ser um requisito necessário para que os entes a que a legislação atribuiu a legitimidade ativa extraordinária possam propor ações coletivas.

As divergências doutrinárias se iniciam, entretanto, ao se discutir de que forma será feito o juízo de adequação desses representantes - especialmente diante da ausência de uma previsão expressa, nas leis que disciplinam os processos coletivos no país, acerca da possibilidade e da necessidade de se aferir esse requisito ${ }^{423}$.

\footnotetext{
${ }^{421}$ GIDI, Antonio. A representação adequada nas ações coletivas brasileiras: uma proposta. Revista de processo, São Paulo, n.108, p. 69-70, out/dez. 2002.

${ }^{422}$ Como visto, o professor Rodolfo de Camargo Mancuso, conquanto entenda que a representatividade adequada não pode ser aferida pelo juiz no ordenamento jurídico brasileiro, tendo sido reconhecida ope legis para os legitimados ativos, concorda com o fato de que é por meio da representatividade adequada que se consubstancia a garantia do devido processo legal nos processos coletivos. De outra banda, entre os processualistas que entendem ser possível a aferição da representatividade adequada, pelo mesmo motivo de preservação das garantias constitucionais do processo justo -, estão Ada Pellegrini Grinover, Kazuo Watanabe, Álvaro Valery Mirra, entre outros.

${ }^{423}$ Como anteriormente já se mencionou, o projeto de Lei 3.034/1984 (projeto Flávio Bierrenbach) que pretendia disciplinar as Ações Civis Públicas no país, elaborado por uma comissão de juristas que incluía os professores Ada Pellegrini Grinover e Kazuo Watanabe, previa expressamente a necessidade de se aferir a representatividade adequada - aferição essa que seria feita em cada caso concreto pelo Poder Judiciário. Tal projeto, no entanto, foi substituído por aquele apresentado pelos integrantes do Ministério Público Paulista, que se transformou na Lei. 7.347/1985 - vigente desde então com poucas alterações -, a qual, como é de conhecimento geral, não prevê expressamente a necessidade de se aferir o requisito da representatividade adequada. Sobre o assunto ver PASCHOAL, Maximilian Fierro. A representatividade adequada e a discussão quanto à possibilidade do seu controle judicial no Brasil. In: SALLES, Carlos Alberto (coord.). As grandes transformações do processo civil brasileiro - homenagem ao professor Kazuo Watanabe. São Paulo: Quartier Latin, 2009, p. 883-885.
} 
Parte da doutrina pátria entende que os representantes adequados foram eleitos pelo legislador no ordenamento jurídico pátrio, de modo a afastar a possibilidade de aferição de sua atuação no caso concreto pelo juiz. Essa corrente divide-se em duas vertentes.

De um lado estão as opiniões de Rodolfo de Camargo Mancuso e Pedro Silva Dinamarco, os quais entendem que o legislador presume que as entidades arroladas como legitimadas ativas para a propositura de ações coletivas são representantes adequadas dos interesses da coletividade, o que dispensaria a atuação do juiz na verificação da atuação desses autores coletivos no caso concreto ${ }^{424}$. Para esses autores, o fato de não ser positivada a possibilidade do controle jurisdicional da representatividade adequada confirma essa presunção de adequação dos representantes arrolados em lei. E se os legitimados gozam de uma presunção de adequação, conferida pela lei, os requisitos previstos na lei para a atribuição de legitimidade a alguns dos autores coletivos, como as associações civis - a pré-constituição há um ano e a inclusão dos direitos defendidos em suas finalidades institucionais -, nada têm a ver com o instituto da representatividade adequada $^{425}$.

De outro lado, Álvaro Luiz Valery Mirra defende que o legislador estabeleceu condições expressas para a atuação dos legitimados, e que a verificação dessas condições é o mais próximo que o juiz poderia chegar para a verificação da representatividade adequada dos legitimados ${ }^{426}$.

As duas vertentes doutrinárias acima descritas, que negam a possibilidade de uma atuação jurisdicional no caso concreto para aferir a representatividade adequada, apregoam que o juiz deve estar adstrito ao quanto foi positivado para atribuir ou negar a legitimidade ativa ao autor coletivo. Assim, a discricionariedade do magistrado estaria limitada à

\footnotetext{
${ }^{424}$ Sobre o tema, Rodolfo de Camargo Mancuso atesta: "Já nas ações coletivas deve haver um certo temperamento no juízo de admissibilidade, seja em contemplação à sua finalidade - tutela de interesse mentaindividual, evitando a atomização do conflito -, seja pelo fato de que o autor não é o titular do interesse e sim um adequado representante, credenciado ope legis. MANCUSO, Rodolfo de Camargo. Jurisdição coletiva e coisa julgada...Op. cit., p. 284.

${ }^{425}$ Sobre os doutrinadores que defendem que está positivada a possibilidade de aferir a representatividade adequada, manifesta Rodolfo de Camargo Mancuso: "Dizem eles que as associações teriam de demonstrar essa qualidade mediante tempo mínimo de constituição e autorização expressa de seus estatutos ou por deliberação em assembleia. Entretanto, esse requisito nada tem que ver com a representatividade adequada, que exprime um conjunto de fatores que demonstrariam concretamente ao juiz, durante todo o curso do processo, ser o autor pessoa idônea, que irá despender eficazmente todos os esforços necessários para a defesa dos interesses das pessoas ausentes do processo" (MANCUSO, Rodolfo de Camargo. Ação Civil Pública. 6. ed. São Paulo: RT, 1999, p. 201-202). Nesse sentido, ver também DINAMARCO, Pedro Silva. Ação Civil Pública. São Paulo: Saraiva, 2001.

${ }_{426}$ Ver "Ação Civil Pública em defesa do meio ambiente: a representatividade adequada dos entes intermediários legitimados para a causa" (MIRRA, Álvaro Valery. In: MILARÉ, Édis (coord.). A ação Civil Pública após 20 anos: efetividade e desafios. São Paulo: RT, 2005, p. 33-57.
} 
apuração dos requisitos legais que condicionam a legitimidade de algumas entidades arroladas como legítimas pela Lei da Ação Civil Pública e pelo Código de Defesa do Consumidor.

Ocorre que aceitar a tese de que determinados entes são, a priori, representantes adequados dos interesses da coletividade, já se constitui em uma afronta direta à garantia do devido processo legal. A única forma de asseverar a efetivação dessa garantia no processo coletivo é cuidar para que o legitimado ativo - que não se confunde com aquele que sofrerá os efeitos da sentença coletiva - atue com a mesma diligência que o próprio titular do direito atuaria. E isso não pode ser apurado se não pelo juiz e no caso concreto. Não é possível assumir que todas as associações brasileiras constituídas há mais de um ano defenderão adequadamente os interesses a que se propuseram. Tampouco é possível deduzir que o Ministério Público, por ser um órgão idôneo e vinculado ao poder estatal, atuará com a diligência e o vigor necessários em todas as causas.

Esse tipo de controle só pode ser feito com vistas à atuação do legitimado na prática, em cada um dos processos que ele ingressar. Importa dizer que uma mesma associação, para usar como exemplo as entidades que são objetos do presente estudo, poderá ser um representante adequado de determinado grupo, em determinado contexto, e um representante inadequado na discussão dos interesses de um outro grupo, ainda que tenha mais de um ano de constituição e inclua em seus estatutos as suas finalidades institucionais $^{427}$.

Assim, o ponto em que se discorda das opiniões delineadas acima é que a análise da atuação do legitimado ativo - na qualidade de representante -, de forma a verificar durante o curso de todo o processo se os interesses da classe substituída estão sendo adequadamente defendidos, somente poderá ser feita de forma efetiva pelo juiz que aferirá as peculiaridades de cada caso concreto. Em tal análise, o juiz deve estar autorizado a lançar mão de todos os instrumentos legais e principio lógicos, não estando limitado pelos requisitos de atribuição da legitimidade ativa circunscritos nos artigos $82, \mathrm{~V}$, do Código de Defesa do Consumidor, e $5^{\circ}$, V, da Lei da Ação Civil Pública.

Não se discorda que esses requisitos legais - notadamente no caso das associações -, se analisados em profundidade, podem servir como guia aos magistrados na aferição da

\footnotetext{
427 Mais adiante discutir-se-á o caso da Associação Cearense de Defesa da Saúde dos Fumantes e exFumantes (ACEDESFE) que, notoriamente, atua na defesa dos consumidores de tabacos e congêneres mas, por incluir em suas finalidades institucionais a defesa do consumidor, foi considerada legítima para a propositura de ação discutindo contrato de caderneta de poupança.
} 
representatividade adequada, mas certamente não se afiguram suficientes, por si só, para um controle da efetiva representação dos interesses da coletividade pelo legitimado ativo $^{428}$.E essa verificação prescinde a previsão expressa em lei acerca da possibilidade de aferição, visto que decorre da necessidade de garantir a efetivação da garantia constitucional do devido processo legal. Como bem observado por Canotilho, não há no ordenamento jurídico espaços livres de direitos fundamentais ${ }^{429} \mathrm{e}$, nesse sentido, tanto o Código de Defesa do Consumidor quanto a lei da Ação Civil Pública se inserem em um contexto maior, que é ditado pela Constituição Federal. Nas palavras de Antonio Gidi, “[...] pouco importa que a lei infraconstitucional brasileira não preveja expressamente que o juiz deva controlar a adequação do representante. Não se trata aqui de uma questão meramente processual, mas constitucional" ${ }^{\prime 430}$.

Em outras palavras, é o preenchimento de uma garantia constitucional que está em jogo quando se discute a possibilidade ou não do controle ope judicis da representatividade adequada, motivo pelo qual uma lacuna na legislação constitucional deverá ser interpretada de forma sistêmica e preenchida pelo juiz no caso concreto, já que o processo coletivo conta, de uma forma geral, com uma postura ativa do magistrado.

A existência de uma suposta lacuna na lei atinente à possibilidade do controle ope judicis da representatividade adequada, aliás, também deve ser analisada sob o prisma constitucional. É preciso reconhecer que o princípio da legalidade - ao qual estão adstritos todos os delegatários do poder público, o juiz inclusive - não poderá ser utilizado como argumento para afastar a possibilidade de controle jurisdicional da representatividade adequada, partindo do princípio de que se não há lei permitindo a conduta do juiz, esta lhe está vedada $^{431}$. Essa concepção de legalidade está vinculada ao modelo liberal de Estado, em que as garantias se prestavam unicamente a impedir a ingerência do poder estatal na esfera individual - limitando o poder dos agentes estatais estritamente ao quanto estava

\footnotetext{
${ }^{428}$ Ponto este que é reconhecido tanto por Pedro Silva Dinamarco quanto por Rodolfo de Camargo Mancuso, conquanto discordem da possibilidade de aferição ope judicis da representatividade adequada, conforme nota 424.

${ }^{429}$ Ver "Civilização do Direito Constitucional ou constitucionalização do Direito Civil - a eficácia dos direitos fundamentais na ordem jurídico-civil no contexto do direito pós-moderno". CANOTILHO, José Joaquim Gomes. In: GRAU, Eros Roberto; GUERRA FILHO, Willis Santiago (orgs). Direito constitucional - estudos em homenagem a Paulo Bonavides. São Paulo: Malheiros, 2000, p. 112-113. ${ }^{430}$ GIDI, Antonio. A representação adequada nas ações coletivas brasileiras: uma proposta...Op. cit., p. 69.

${ }^{431}$ JUSTEN FILHO, Marçal. Curso de Direito Administrativo. 2. ed. São Paulo: Saraiva, 2006, p.148-149.
} 
previsto de forma expressa na lei. Vigia o conceito de "legalidade formal"432. Nesse contexto, também os poderes do juiz estavam limitados ao texto da lei, o que o transformava em um autômato, que se limitava a dizer a lei aplicável ao caso concreto.

Tais contornos do princípio da legalidade, no entanto, tiveram de ser redesenhados ao longo do tempo, inclusive para atender ao surgimento de outras duas classes de direitos fundamentais - os de segunda e terceira gerações -, passando a ser entendido sob o prisma substancial (legalidade substancial), ou seja, permitindo que a norma aplicável seja interpretada de forma sistêmica e de acordo com o disposto na Constituição Federal - em atenção aos seus princípios e visando garantir a consecução, na prática, dos direitos fundamentais por ela assegurados ${ }^{433}$. Essa mudança implicou, diretamente, o aumento dos poderes conferidos ao juiz - tanto para conduzir o processo quanto para interpretar e aplicar normas voltadas à solução do conflito. E, aumentadas as margens de discricionariedade conferidas aos juízes, sua função passa a incluir também a integração das lacunas eventualmente existentes na legislação, com o objetivo de dar ao caso que se lhe apresenta a melhor solução possível nos limites que o ordenamento jurídico permite ${ }^{434}$.

Essa orientação, como bem destacado por Ada Pellegrini Grinover, compatibilizase com o quanto disposto como deveres do juiz nos artigos $4^{\circ}$ e $5^{\circ}$ da Lei de Introdução às Normas do Direito Brasileiro ${ }^{435}$. O artigo $5^{\circ}$ do referido diploma legal preconiza que o juiz, na aplicação da lei, buscará atender aos fins sociais à que ela se dirige, ao passo que o artigo $4^{\circ}$ se ocupa em dizer que, sempre que a lei for omissa, o juiz decidirá o caso de

432 Explica Celso Antonio Bandeira de Mello: "O princípio da legalidade contrapõe-se, portanto, e visceralmente, a quaisquer tendências de exacerbação personalista dos governantes. Opõe-se a todas as formas de poder autoritário, desde o absolutista, contra o qual irrompeu, até as manifestações caudilhescas ou messiânicas típicas dos países subdesenvolvidos. O princípio da legalidade é o antídoto natural do poder monocrático ou oligárquico, pois tem como raiz a idéia de soberania popular, de exaltação da cidadania" (MELlO, Celso Antonio Bandeira de. Curso de Direito Administrativo. 17. ed. São Paulo: Malheiros, 2004 , p. 91.

${ }^{433}$ Não se fala, portanto, em uma flexibilização do princípio da legalidade, mas, simplesmente em uma revisão do conceito, para que seja possível aos poderes do Estado - entre eles o judiciário - dar efetividade às normas constitucionais, notadamente aos direitos fundamentais, que pedem atualmente uma postura mais ativa dos agentes estatais. PASCHOAL, Maximilian Fierro. A representatividade adequada nas ações coletivas brasileiras...Op. cit., p. 163.

${ }^{434}$ Nos dizeres de Marcus Vinícius de Abreu Sampaio: “[...] a atividade do juiz nas hipóteses que estamos tratando, não se cinge à interpretação de um conceito vago. Vai muito mais além. O Juiz além de interpretar, em tese, um determinado conceito vago, deverá associá-lo ao caso ou fato concreto; verificar os momentos social, político e econômico que envolvem o litígio, verificar essas mesmas condições, no que diz respeito às partes envolvidas; verificar também qual a melhor - e não a única - solução para aquele caso, a fim de preservar não só o direito das parte envolvidas, como também e principalmente, a eficácia de sua atividade típica, do processo e da jurisdição, como poder emanado do Estado" (SAMPAIO, Marcus Vinicius de Abreu. O poder geral de cautela do juiz. São Paulo: RT, 1993, p.104-106).

${ }^{435}$ Ver "Novas questões sobre a legitimidade e a coisa julgada nas ações coletivas". GRINOVER, Ada Pellegrini. O processo: estudos e pareceres. São Paulo: Editora Perfil, 2006 p. 214. 
acordo com a analogia, os bons costumes e os princípios gerais do direito. Partindo disso, ainda que não exista uma previsão expressa da possibilidade de aferição da representatividade adequada, o sistema jurídico atual espera do juiz uma postura ativa, buscando atender os fins colimados pela lei - e pela garantia constitucional do devido processo legal -, preenchendo eventuais lacunas que impeçam a consecução desses fins.

Negar esse papel ao juiz equivale a legá-lo a uma posição passiva que não se coaduna com as suas atuais funções, especialmente no âmbito dos processos coletivos, em que o escopo publicista está em clara evidência. O juiz não tem um mero direito subjetivo, faculdade, poder ou prerrogativa, mas um poder funcional ${ }^{436}$. Assim, ele não só pode, como deve, adotar uma postura ativa para resguardar as garantias constitucionais e as cláusulas gerais que permeiam o processo coletivo, visando assegurar seu bom termo e o resguardo dos direitos da coletividade. Admitir que o magistrado deva se abster, ainda que diante da flagrante inadequação do representante do grupo, equivale a retirar-lhe sua defining function nos processos coletivos, enquanto condutor da demanda ${ }^{437}$.

E, principalmente no que se refere às associações, se estaria a admitir que aquela que se apresenta - no papel - como representante de determinada classe, ao propor uma ação coletiva no Brasil, pode ser desde inepta até mal intencionada e, ainda assim, ver suas condutas no processo vinculando todo o grupo. Essa reflexão é proposta por Antonio Gidi que, em um evento sobre processos coletivos, propôs a mesma questão à estudiosa americana do tema, a professora Linda Mullenix:

\footnotetext{
${ }^{436}$ O poder conferido ao juiz é o que se convencionou chamar de poder funcional, já que é conferido pelo Estado a seu delegatário para que, com ele, se cumpra o dever que lhe foi atribuído - dizer o direito. Nesse sentido, se o juiz pode fazer determinada análise, é seu dever fazê-lo - já que ele só é titular desse poder para concluir um dever. Nas palavras de Messineo, que usa como exemplo o poder funcional do poder familiar: "[...] o poder familiar é concedido como meio para o cumprimento de um dever igualmente familiar, a obrigação impõe-se ao proprietário como consequiência e acessório do poder. No caso do poder familiar, o elemento central é o dever; para o cumprimento do mesmo, concede-se um poder (chamado poder-dever ou direito-dever)", ver: MESSINEO, Francesco. Manuale di diritto civile e commerciale. Vol 3. 9.ed. Milano:, Giuffrè, 1959. MACHADO, Hermano Augusto. A função social e a tipificação no direito de propriedade. São Paulo: Saraiva, 1997, p. 255. Sobre o assunto, ver também GIDI, Antonio. A representação adequada nas ações coletivas brasileiras: uma proposta...Op. cit., p. 61-70.

${ }^{437}$ Cássio Scarpinella Bueno, ao manifestar-se favoravelmente ao controle jurisdicional da representatividade adequada, mediante uma postura ativa do juiz, diz: "O juiz deve ter, ainda, participação ativa na averiguação de se tratar a hipótese fática trazida à sua presença um daqueles casos previstos - de forma infeliz - pelo nosso legislador para justificar a propositura de ação coletiva. Deverá exigir que seja descrita a coletividade, deverá, se entender necessário, convocar e ouvir membros da coletividade, deverá verificar, ainda, quais os interesses que prevalecem no interior dessas mesmas coletividades. Realizada essas tarefas, estarão superados muitos óbices que poderiam ser postos para a solução brasileira da coisa julgada" (BUENO, Cassio Scapinella. As class actions norte-americanas e as ações coletivas brasileiras: pontos para uma reflexão conjunta. Revista de Processo, São Paulo: Revista dos Tribunais, v.21, n.82, abr.-jun. 1996, p.142).
} 
[...] vamos dizer a ela que, no Brasil, um representante pode ser incompetente, relapso, medíocre, fraudulento e ainda assim a sua conduta no processo poderá vincular todo o grupo que ele representa. Vamos dizer-lhe que as ações (e inações) desse representante refogem a todo e qualquer controle judicial, por mais evidente que sejam suas imperfeições. Vamos dizer isso a ela e vamos esperar sua reação. Sabemos qual é a reação, porque já fizemos esse exercício e a sua reação imediata foi invocar o devido processo legal. Ela nos perguntou: "vocês não tem aqui no Brasil um conceito semelhante ao nosso due process of law?". 438

E essas observações foram feitas também por um dos idealizadores da tutela coletiva nos ordenamentos de Civil Law, Mauro Cappelletti, que, desde o início dos debates acerca dos processos coletivos, alertou para o perigo de abusos por parte dos novos legitimados, particularmente das associações, as quais poderiam se tornar centro de opressão - seja em relação a seus membros ou em relação a terceiros ${ }^{439}$.

Seguindo a linha de pensamento proposta por Antonio Gidi e Mauro Cappelletti no que tange à atuação das associações, e o quanto desenvolvido nesse capítulo sobre a indispensabilidade de uma representação vigorosa e idônea para a efetivação da garantia do devido processo legal e a manutenção da ordem constitucional estabelecida, conclui-se que a observação minuciosa, a ser feita pelo juiz, da atuação dessas entidades no caso concreto, mais do que assegurar o devido processo legal - contraditório e ampla defesa - e, com isso, a força vinculante da decisão coletiva, permitiria também afastar da tutela coletiva os autores inidôneos, que agem motivados pela perspectiva de ganhos pessoais, muitas vezes imbuídos de má-fét 440 .

Assim, aferir a representatividade adequada se presta, ainda, a preservar a boa-fé nas relações jurídicas processuais - no âmbito do processo coletivo - coibindo o abuso do direito de demandar. É esse aspecto da possibilidade do controle jurisdicional da representatividade adequada que se passa a analisar no próximo tópico.

\subsubsection{A representatividade adequada como forma de garantir a preservação da boa-} fé objetiva e evitar o abuso de direito de demandar nos processos coletivos

\footnotetext{
${ }^{438}$ GIDI, Antonio. A representação adequada nas ações coletivas brasileiras: uma proposta...Op. cit., p. 65.

${ }^{439}$ CAPPELLETTI, Mauro. Formações sociais e interesses coletivos diante da justiça civil. São Paulo: RT, n. 5, jan./mar. 1977, p. 128-159. Ver, também, PASCHOAL, Maximilian Fierro. A representatividade adequada nas ações coletivas brasileiras...Op. cit., p. 183.

${ }^{440}$ Afinal, como pontua Antonio Gidi, “[...] seria ingênuo considerar que cada associação existente no Brasil, pela simples circunstância de estar constituída há mais de um ano, possa ser um representante adequado na tutela de qualquer direito da comunidade em juízo" (GIDI, Antonio. A representação adequada nas ações coletivas brasileiras: uma proposta...Op. cit., p. 64).
} 
6.1.2.1. Dos fundamentos da vedação ao abuso de direito

A vedação ao abuso de direito é construída com base no conceito de boa-fé. Tal construção se deu ao longo do desenvolvimento das teorias acerca da boa-fé no decorrer da história, tendo ficado claro que esse conceito permeia todos os ordenamentos jurídicos, não havendo que se pensar no direito, em si, desvinculado da boa-fé. Antes de falar das teorias do abuso de direito e verificar de que forma as associações podem adotar esse tipo de conduta ao propor ações coletivas - e como a representatividade adequada pode auxiliar no combate a essas atitudes -, faz-se necessária uma breve análise dos fundamentos históricos e dogmáticos da boa-fét ${ }^{441}$.

O termo boa-fé é dotado de vários significados que foram se desenvolvendo e se condensando ao longo da história. Sua origem remonta ao direito romano (fides), no qual assumia uma ideia de garantia ou promessa, muitas vezes expressando conotações religiosas e éticas - carregadas da concepção de dever e de respeito à palavra dada ${ }^{442}$. Assim, com fundamento nessa concepção de confiança entre as partes, foi criada pelo pretor romano uma ação (actio), a chamada bona fidei iudicia, que tinha como função assegurar o cumprimento da obrigação com base no que foi acordado entre as partes ${ }^{443}$.

Essa nova actio ampliou sobremaneira a liberdade do pretor na análise dos negócios jurídicos - com base no caso concreto - e, por conseguinte, implicou a abertura do leque de pretensões até então existentes no direito romano, conferindo proteção a diversas situações jurídicas com base unicamente na boa-fé (fides) ${ }^{444}$. Com isso, pontua Menezes Cordeiro que o conceito de boa-fé, ainda sob a égide do direito romano, foi alçado à natureza jurídica objetiva de comportamento honesto e correto, do ponto de vista

\footnotetext{
${ }^{441}$ Não se pretende, neste estudo, fazer uma análise profunda da evolução histórica das teorias sobre o abuso de direito, uma vez que o foco será o abuso do direito processual perpetrado pelas associações na propositura de ações coletivas. Entretanto, para compreender de uma forma global o abuso do direito processual, é preciso buscar suas raízes no direito material, começando-se pela boa-fé.

${ }^{442}$ FRITZ, Karina Nunes. Boa-fé objetiva na fase pré-contratual - a responsabilidade pré-contratual por ruptura das negociações. Curitiba: Juruá, 2009, p. 83-84. Sobre as concepções metajurídicas de boa-fé, relacionando-as a conceitos de moral e ética, veja-se também MENEZES CORDEIRO, Antonio Manuel da Rocha. Da boa-fé no direito civil. $3^{\text {a }}$ reimpressão. Coimbra: Almedina, 2007 p. 1160-1175.

${ }^{443}$ A criação dessa actio romana data do período formular, em que só existia um direito se existisse ação que a ele correspondesse - não havia o reconhecimento abstrato das posições jurídicas. Assim, os bona fidei iudicia eram ações fundadas em fatos em que se exigia do devedor o cumprimento da obrigação com base no quanto havia sido acordado entre as partes, o que fazia com o que o pretor pudesse analisar o caso concreto não necessariamente com base exclusivamente legal, mas também analisando a base ética que permeava o negócio. Ver FRITZ, Karina Nunes. Boa-fé objetiva na fase pré-contratual - a responsabilidade précontratual por ruptura das negociações...Op. Cit., p. 84-85.

${ }^{444}$ Ibid., p. 85.
} 
pragmático característico daquele contexto, e não mais remetendo a valores extrajurídicos - tais quais como a ética e a moral ${ }^{445}$.

Com o passar do tempo e com a ascensão do cristianismo, a boa-fé passou a ser utilizada indiscriminadamente para caracterizar diversos e dissonantes fenômenos jurídicos, passando a ganhar importância e incorporar conceitos extrajurídicos como os valores éticos e morais. Por conta disso, deu-se o que se chamou de diluição horizontal e vertical do conceito:

A primeira [diluição horizontal] ocorre quando a expressão qualificativa de um instituto jurídico passa a designar outro instituto diferente, enquanto a segunda [diluição vertical] se verifica quando essa expressão passa a traduzir um princípio de direito. O fenômeno da diluição horizontal aparece com o surgimento da usucapião no direito romano, quando os jurisprudentes romanos criaram o termo bona fides para expressar os requisitos para a aquisição da propriedade. A expressão nova ganhou o significado de estado psicológico de ignorância, incidindo nos direitos reais, embora tenha sido com o tempo estendida a outros ramos do direito.

Além dessa alteração horizontal, sofre a figura ainda uma diluição vertical no interior do próprio direito das obrigações, mesclando-se e confundindo-se com a equidade, princípio de justiça ao qual recorre o juiz para, na solução do caso concreto, flexibilizar a rigidez da norma jurídica. A aequitas, por muitos considerada o segundo pilar da atual concepção de boa-fé objetiva, era utilizada no direito romano como um critério objetivo de valoração das relações jurídicas, contendo ainda a idéia de tratamento isonômico de tratar o igual da mesma forma ${ }^{446}$.

Tendo sido recepcionada pelo direito europeu continental sob influência do direito canônico - que acabou retomando as concepções extrajurídicas como a ausência de pecado -, a boa-fé chegou à primeira grande codificação (o Código Civil Francês de 1804) desvinculada do ideário romano de lealdade no comportamento dos contratantes e impregnada pelo subjetivismo do conceito de equidade ${ }^{447}$. Essa concepção subjetiva da boa-fé, no entanto, não se afigurou suficiente para resolver todos os problemas práticos envolvendo condutas que desbordavam os padrões razoáveis no exercício dos direitos. Para

\footnotetext{
${ }^{445}$ MENEZES CORDEIRO, Antonio Manuel da Rocha. Da boa-fé no direito civil...Op. cit., p. 97-105.

${ }^{446}$ FRITZ, Karina Nunes. Boa-fé objetiva na fase pré-contratual...Op. cit., p. 86.

${ }^{447}$ Sobre a positivação da boa-fé subjetiva e objetiva no Código Civil francês, pontua Karina Nunes Fritz: "Consagrava a boa-fé subjetiva em diversos dispositivos em sua idéia nuclear de situação subjetiva, estado de ignorância acerca de determinada situação jurídica, sendo, nos direitos reais, definida no art. 550 sob a ótica do sujeito: possuidor de boa-fé é aquele que possui como proprietário em virtude de título translativo de propriedade, cujos vícios ignore. A boa-fé objetiva, por sua vez, encontra-se no art. 1.134 III, segundo o qual as partes devem executar as obrigações de boa-fé. Apesar de tal norma, doutrina e jurisprudência francesas não conseguiram retirar muitas potencialidades da boa-fé objetiva, limitando-se, em decorrência sobretudo do método exegético desenvolvido após a entrada em vigor do Code - caracterizado essencialmente pela estrita vinculação, formal e material, do julgador ao texto legal - a ver a boa-fé incidente nas relações obrigacionais ora como mero reforço ao pactuado, ora como proscrição de dolo ou fraude" (FRITZ, Karina Nunes. Boa-fé objetiva na fase pré-contratual...Op. cit., pp. 88-89).
} 
resolver conflitos dessa natureza, os tribunais franceses acabaram por desenvolver, na prática, o conceito de exercício abusivo de direito.

Diversos doutrinadores, dentre os quais se destacam o trabalho de Josserand ${ }^{448}$ e Menezes Cordeiro $^{449}$, compilaram uma série de decisões dos tribunais franceses, prolatadas ao longo do século XIX, em que tais tribunais, não obstante tenham reconhecido a existência de um direito, consideraram o exercício desse direito abusivo ou inadmissível ${ }^{450}$. Dentre esses casos, podem ser citados os seguintes: (i) em 1808, o proprietário de uma fábrica de chapéus teve seu direito limitado por conta dos odores desagradáveis que exalavam para a vizinhança ${ }^{451}$; (ii) em 1820 , houve a condenação do construtor de um forno que, por negligência, prejudicava seu vizinho ${ }^{452}$; (iii) em 1855 , foi condenado o proprietário que havia construído uma falsa chaminé para vedar a incidência de luz sobre a propriedade do vizinho ${ }^{453}$; e (iv) ainda em 1855 houve a condenação do proprietário que ergueu estacas de 16 metros cobertas com espigões de ferro com o fito de danificar os dirigíveis que pousariam no imóvel vizinho ${ }^{454}$.

As situações que deram origem aos julgados supracitados, embora tratassem precipuamente do direito de propriedade, foram compiladas pelo belga Laurent sob o termo "abuso de direito" 455 , que não está limitado a tais casos, compreendendo uma miríade de situações. Assim, a vedação ao abuso de direito ganhou espaço na França.

$\mathrm{Na}$ Alemanha, com a entrada em vigor do Bürgerliches Gesetzbuch em 1900 (Código Civil Alemão - BGB), passou-se a estudar o arcabouço teórico que serviria para coibir os casos de abuso de direito. O primeiro fundamento utilizado para tanto foi o parágrafo 226 do BGB, que vedava comportamentos emulativos ${ }^{456}$. Esse artigo, no entanto, não era capaz de, sozinho, fundamentar a vedação a todos os casos de exercício abusivo de

\footnotetext{
${ }^{448}$ JOSSERAND, Louis. Cours de droit civil positif français. 2. ed. Paris: Sirey, 1932, p. 1.475. ${ }^{449}$ MENEZES CORDEIRO, Antônio Manuel da Rocha. Da boa fé no direito civil...Op. cit., p. 671.

${ }^{450}$ Menezes Cordeiro critica o uso da expressão "abuso de direito", pois não apenas "direitos" podem ser exercidos de forma inadmissível, mas também outras posições jurídicas como faculdades e poderes. Em vista disso, ele sugere a utilização da expressão "exercício inadmissível de posições jurídicas" (Ibid., p. 671).

${ }^{451}$ C. Imp. Metz, 10 de novembro de 1808, S 1821, 2, 154.

${ }^{452}$ C. Imp. Metz, 16 de agosto de 1820, S 1821, 2, 155.

${ }^{453}$ C. Imp. Colmar, 2 de maio de 1855, D 1856, 2, 9-10.

${ }^{454}$ Compiègne, 19 de fevereiro de 1913, D 193, 2, 181 e CassFr, 3 de agosto de 1915, D 1917, 1, 79.

${ }^{455}$ MENEZES CORDEIRO, António Manuel da Rocha. Da boa fé no direito civil...Op. cit., p. 670.

${ }^{456} \$ 226$. Die Ausübung eines Rechts ist unzulässig, wenn sie nur den Zweck haben kann, einem anderen Schaden zuzufügen.(tradução livre: o exercício de um direito é inadmissível se tiver por fim exclusivo causar dano a outrem.)
} 
direito - mesmo porque nem todo exercício inadmissível de direito se presta exclusivamente a causar dano a outrem ${ }^{457}$.

Em vista da insuficiência do parágrafo 226 do BGB, buscou-se fundamentar a vedação ao abuso de direito no parágrafo 826 do BGB, o qual proibia o atentado aos bons costumes, ou seja, à ética e ao decoro. Esse fundamento, entretanto, remetia-se a conceitos extrajurídicos que, mais uma vez, foram considerados insuficientes para coibir os atos abusivos.

O fundamento encontrado pelos alemães para coibir o abuso de direito foi a cláusula geral de boa-fé objetiva (Treu und Glauben) circunscrita no parágrafo 242 do $\mathrm{BGB}^{458}$. A boa-fé objetiva, pois, passa a ser interpretada como sendo dotada de uma tripla função: interpretativa - por ajudar na interpretação dos contratos; integrativa - por ajudar a suprir eventuais lacunas nesses contratos; e, por fim, limitativa - impedindo que o negócio ou ato jurídico ultrapasse os limites do justo ${ }^{459}$. Nesta última função é que se encontra o fundamento para coibir os atos abusivos ou emulativos. E essa previsão passa a ser aplicada não apenas às relações jurídicas contratuais, mas também às relações em geral.

Gradativamente, a boa-fé objetiva foi alçada ao patamar de limite ético ao exercício de posições jurídicas de uma forma geral. Até porque, como ressalta Larenz, foi o resguardo à dignidade humana que primeiro impôs o dever de respeito mútuo entre todos os membros da sociedade, constituindo-se como raiz do conceito da boa-fé objetiva:

\begin{abstract}
A raiz do princípio de boa-fé encontra-se, em Larenz, no personalismo ético, fundamento básico do Código Civil Alemão, e que traduz a consideração do homem enquanto fim em si mesmo, idéias cujas raízes se encontram na religião cristã e na filosofia kantiana, da qual decorre a necessidade elementar de respeito à pessoa e à sua dignidade [...]. O princípio do respeito mútuo integra a base de todo ordenamento jurídico e constitui, no dizer de Larenz, o caráter fundamental do direito justo. A dignidade humana consiste, assim, em valor máximo do sistema jurídico, razão pela qual Reale a qualifica como valor-fonte e, enquanto tal, é fonte também dos mais importantes princípios do direito privado ${ }^{460}$.
\end{abstract}

\footnotetext{
${ }^{457}$ LOPES, Teresa Ancona. Exercício do direito e suas limitações: abuso do direito. Revista dos Tribunais, São Paulo: RT 885, $98^{\circ}$ ano, jul.2009, p. 55-56.

${ }^{458} \$ 242$. Der Schuldner ist verpflichtet, die Leistung so zu bewirken, wie Treu und Glauben mit Rücksicht auf die Verkehrssitte es erfordern. (tradução livre: $\mathrm{O}$ devedor está obrigado a executar a prestação de acordo com a boa-fé, considerando os usos e costumes).

459 Ver "Insuficiências, deficiências e desatualização do projeto de Código Civil (atualmente, código aprovado) na questão de boa-fé objetiva nos contratos" (JUNQUEIRA DE AZEVEDO, Antonio. Estudos e pareceres de direito privado. São Paulo: Saraiva, 2004, p. 153.

${ }^{460}$ LARENZ, Karl; WOLF, Manfred. Allgemeiner Teil des Bürgerlichen Rechts. 9.ed. München: C.H. Beck, 2004, p. 21-29 e FRITZ, Karina Nunes. A boa-fé objetiva na fase pré-contratual...Op. cit., p. 105.
} 
E a cláusula geral de boa-fé consolidada na doutrina e na jurisprudência da Alemanha foi adotada como base pelo artigo 334 do Código Civil Português que, por sua vez, serviu como inspiração para o Código Civil brasileiro, o qual entrou em vigor no ano de 2003. Aos moldes da codificação estrangeira em questão, o nosso diploma civil tratou da boa-fé objetiva em diferentes dispositivos. Alguns deles diretamente voltados para coibir o abuso de direito, como é o caso do artigo 187- que desde logo caracteriza como ato ilícito aquele praticado fora de determinados limites -, deixando clara a função limitativa da boa-fé. Outros destacando também as funções integrativa e interpretativa, como é o caso do artigo $422^{461}$.

Apesar de terem sido incluídas no Código Civil, a boa-fé e a vedação ao abuso de direito (rectius: exercício inadmissível de posições jurídicas ${ }^{462}$ ) são valores fundantes não apenas do Código Civil, mas de todo o ordenamento jurídico. A rigor:

\begin{abstract}
A boa-fé, em homenagem a uma tradição bimilenária, exprime os valores fundamentais do sistema. Trata-se de uma visão que, aplicada ao abuso de direito, dá precisamente a imagem propugnada. Dizer que, no exercício dos direitos, se deve respeitar a boa-fé, equivale a exprimir a idéia de que, nesse exercício, se devem observar os vetores fundamentais do próprio sistema que atribui os direitos em causa ${ }^{463}$.
\end{abstract}

O doutrinador português, e estudioso do tema, Antonio Menezes Cordeiro, responsável pelo trecho supracitado, buscou definir o que se deve entender por boa-fé. Em primeiro plano explorou o ponto de vista dogmático, a partir do qual a boa-fé pode ser entendida como um conceito indeterminado - em virtude da sua vagueza -, normativo, perceptivo e com margem de discricionariedade variável, surgindo, por vezes, como cláusula geral, revestindo-se de feições típicas a partir do reagrupamento das decisões a que dê lugar ${ }^{464}$. Ou seja, reconhece-se que, desde logo, a concepção dogmática não é suficiente para delimitar os critérios a serem observados no comportamento daquele que age ou não de acordo com a boa-fé. Essa análise só é possível de se fazer no caso concreto ou, como pontuado pelo mesmo doutrinador:

\footnotetext{
${ }^{461}$ Artigo 422. Os contratantes são obrigados a guardar, assim na conclusão do contrato, como em sua execução, os princípios de probidade e boa-fé.

$462 \mathrm{O}$ autor Menezes Cordeiro critica a expressão abuso de direito, ver nota 450. Entretanto, como a expressão abuso de direito é utilizada correntemente na doutrina pátria, apesar da procedente crítica do doutrinador português, ela será adotada no presente estudo.

${ }^{463}$ MENEZES CORDEIRO, António Manuel da Rocha. Da boa fé no direito civil...Op. cit., p. 662-663.

${ }^{464}$ Ibid., p. 1196.
} 


\begin{abstract}
A boa-fé e o abuso do direito não são compatíveis com análises racionalistas ou aparentemente racionalistas, já que a Razão, para o ser, examina o real não funcionando, apenas, sobre si própria. Exigem valorações e um atendimento ao poder dos factos ${ }^{465}$.
\end{abstract}

Assim, preencher de significado a ideia de boa-fé depende, em grande medida, de sua observação prática. Em outras palavras, o conceito seria definido por aquilo que ela pretende evitar - isto é, ações que afrontem a coerência interna do sistema jurídico sem que, necessariamente, violem frontalmente alguma lei. Trata-se, em última análise, da tutela da confiança que deve permear as relações jurídicas de uma forma geral ${ }^{466}$. Foi essa estruturação do conceito de boa-fé objetiva no decorrer da história, e sua consolidação como corolário de confiança entre as partes de um contrato e como limite ao exercício de direitos, que permitiu o desenvolvimento das teorias do abuso de direito no âmbito dos mais diversos ramos da ciência jurídica.

\title{
6.1.2.2. Os elementos do abuso de direito
}

A base da teoria do abuso de direito no âmbito do processo parte do fato de que os atos dos sujeitos de direito, enquanto partes de uma relação jurídica processual, não estão sujeitos apenas às normas processuais, mas também àquelas que regulam a vida civil ${ }^{467}$.

A teoria do abuso de direito foi desenvolvida com vistas à ideia de que os direitos não podem e nem devem ser entendidos como absolutos - seu exercício deve ser pautado por alguns limites que, quando ultrapassados, caracterizam o exercício como abusivo e, como tal, é merecedor de repressão. Os limites, por sua vez, são desenhados pelos fins econômicos e sociais decorrentes da lei ou, quando se estiver no campo do autorregramento da vontade, do negócio jurídico ${ }^{468}$. Essa construção doutrinária

\footnotetext{
465 MENEZES CORDEIRO, António Manuel da Rocha. Litigância de má-fé, abuso do direito de ação e culpa "in agendo". 2. ed. Coimbra: Almedina, 2011, p. 121.

466 Nesse sentido, pontua Menezes Cordeiro: "Nas suas manifestações subjectiva e objectiva, a boa-fé está ligada à confiança: a primeira dá, desta, o momento essencial; a segunda confere-se a base juspositiva necessária quando, para tanto, falte uma disposição legal específica. Ambas, por fim, carreiam as razões sistemáticas que se realizam na confiança e justificam, exemplificando, a sua dignidade jurídica e cuja projeção transcende o campo civil" (MENEZES CORDEIRO, Antonio Manuel da Rocha. Da boa-fé no direito civil...Op. cit., p. 1250-1251).

${ }^{467}$ ABDO, Helena Najjar. O abuso do processo. São Paulo: Ed. RT, 2007, p.27.

${ }^{468}$ Sobre a configuração de determinados atos como abusivos, Menezes Cordeiro se manifesta sobre o artigo 334 do Código Civil Português :"O elemento literal exprime um âmbito unificado por parte da previsão - o exercício do direito e o seu excesso manifesto perante certo limites - por uma qualificação, em epígrafe - o abuso - e pela estatuição - a ilegitimidade ou, melhor dizendo, a proibição; reparte-o, porém, por três áreas atinentes à previsão: em causa ficam os limites impostos pela boa-fé, pelos bons costumes ou pelo fim social ou econômico dos direitos. Do enunciado, por dedução, retira-se que a boa-fé e os bons costumes impõem,
} 
relativamente recente - que, com o tempo, também se refletiu nas legislações - foi uma reação à visão individualista, que concebia os direitos como passíveis de exercício pleno e absoluto.

Nesse sentido, é possível identificar os elementos básicos que devem estar presentes para que se identifique, na prática, o exercício abusivo de um direito: (i) a preexistência de um direito, uma vez que só se pode abusar de um direito do qual se seja titular; (ii) a aparência de legalidade de que o ato abusivo se reveste, de modo que o exercício do direito se revela irregular a partir do momento que se observe o desvio de finalidade legal ou negocial (que pode, assim, ser considerado como o terceiro requisito). A doutrina atual é pacífica quanto à necessidade da presença concomitante desses elementos para a configuração do abuso, mas diverge quanto à necessidade da identificação do elemento subjetivo para que a conduta seja tida como abusiva ${ }^{469}$.

Tal doutrina se divide na defesa de três teorias para a identificação dos elementos do abuso de direito: a teoria subjetivista, a teoria objetivista e a teoria eclética. A teoria subjetivista é defendida por expoentes como Humberto Theodoro Junior, Luiz Guilherme Loureiro e Arnaldo Rizzardo, que entendem que a configuração do abuso de direito depende, em síntese, da presença dos seguintes elementos: (i) existência de um direito; (ii) o exercício doloso (emulativo) ou culposo desse direito, ultrapassando os limites impostos por sua finalidade econômico-social; e (iii) a existência de dano ${ }^{470}$.

A teoria objetivista, ou finalista, por sua vez, é defendida por Teresa Ancona Lopes $^{471}$, Nelson Nery Junior e Rosa Maria de Andrade $\mathrm{Nery}^{472}$, Helena Najjar Abdo, dentre outros. Essa teoria entende ser irrelevante a existência ou não de intenção do agente

ou podem impor, limites ao exercício dos direitos e que estes têm, ou podem ter, um fim social e econômico o qual, por seu turno, limita também, ou pode limitar, seu exercício" (MENEZES CORDEIRO, Antonio Manuel da Rocha. Boa fé no direito civil...Op. cit, p. 661).

${ }^{469}$ As teorias subjetivistas são calcadas na necessidade de identificação da intenção do agente (dolo ou culpa) para a caracterização do abuso; as objetivistas, ou finalistas procuram abstrair esse critério, privilegiando a presença do desvio de finalidade; as ecléticas sugerem uma combinação das duas anteriores, identificando os motivos que levaram à prática do ato e, também, o desvio de finalidade. Ver Helena Najjar Abdo. O abuso do processo...Op. cit., p. 38-42.

470 THEODORO Junior, Humberto. Comentários ao novo código civil. tomo 1. Vol 3. Rio de Janeiro: Forense, 2003; LOUREIRO, Luiz Guilherme. Contratos no novo código civil: teoria geral e contratos em espécie. São Paulo: Método, 2005; LOUREIRO, Luiz Guilherme. Teoria geral dos contratos no novo código civil. São Paulo: Método, 2002; RIZZARDO, Arnaldo. Parte geral do código civil. Rio de Janeiro: Forense, 2003.

${ }^{471}$ LOPES, Teresa Ancona. Exercício do direito e suas limitações: abuso do direito. São Paulo: RT 885, Ano 98, julho de 2009, p. 49-68.

472 Ver comentários ao art. 187 (NERY Junior, Nelson; ANDRADE, Rosa Maria Barreto Borriello de. Código Civil comentado. 6. ed. São Paulo: RT, 2008, p. 368-371) 
em perpetrar o abuso de direito. O ordenamento jurídico brasileiro, ao positivar o abuso de direito no artigo 187 do Código Civil vigente, não mencionou o elemento subjetivo ${ }^{473}$, estabelecendo a hipótese de ato-fato ilícito ${ }^{474}$, em que é prescindível o elemento volitivo do agente $^{475}$.

Há, ainda, uma teoria denominada eclética, cujos defensores ${ }^{476}$ entendem haver abuso de direito quando este é exercido em violação às suas finalidades econômico-sociais, bem como quando há culpa ou dolo (elemento subjetivo). No entanto, ao reconhecer a existência de abuso de direito independente da verificação do elemento subjetivo, a teoria eclética, na verdade, não se diferencia da teoria objetiva. Ressalta-se, mais uma vez, que a teoria objetiva não repudia o elemento subjetivo, mas apenas entende não ser relevante para configuração do abuso de direito.

O Código Civil vigente, por sua vez, filia-se à teoria objetivista ou finalista. Essa teoria nos parece a mais adequada, por ser um reflexo da adoção da boa-fé como princípio fundante do ordenamento jurídico brasileiro, como discutido anteriormente. Ao ser assim considerada, a boa-fé desempenha diversas funções, servindo como norma de interpretação (artigo 113 do Código Civil), cláusula geral criadora de deveres laterais (Nebenpflichten) no campo contratual (artigo 422 do Código Civil) e também tem aplicação na limitação do exercício de direitos.

Portanto, nada mais coerente que considerar antijurídico o exercício do direito que exceda os limites impostos pelo seu fim econômico e social, pela boa-fé e pelos bons costumes. Em suma, a tutela da boa-fé também se exerce por meio do art. 187 do atual Código Civil $^{477}$. Nesse sentido é o entendimento de Antonio Junqueira de Azevedo:

\footnotetext{
473 “Art. 187. Também comete ato ilícito o titular de um direito que, ao exercê-lo, excede manifestamente os limites impostos pelo seu fim econômico ou social, pela boa-fé ou pelos bons costumes."

${ }^{474}$ Há controvérsia na doutrina acerca da autonomia e classificação do abuso de direito como ato ilícito. Nesse aspecto, é salutar o entendimento de Teresa Ancona Lopes para a qual o abuso de direito, a despeito do disposto no artigo 187 do Código Civil, é figura autônoma com relação ao ato ilícito, devendo ser considerado um ato ilícito sui generis, visto que independe de culpa. (LOPES, Teresa Ancona. Exercício do direito e suas limitações: abuso do direito...Op. cit., p. 60-62).

${ }^{475}$ A respeito de atos-fatos ilícitos, Marcos Bernardes de Mello esclarece que "[...] em outras situações, há contrariedade a direito em decorrência de ato-fato, ou seja, de fato produzido pelo homem do qual, no entanto, a norma jurídica abstrai a vontade em praticá-lo, para considerar, apenas, o seu resultado fáctico. Quando alguém faz mau uso de sua propriedade e causa dano a terceiro, há um ato-fato ilícito; não importa a vontade em prejudicar, mas o simples fato do prejuízo (ou ameaça) à segurança, sossego e saúde dos vizinhos. O mesmo ocorre quando alguém toma posse de bem com violação da posse de outrem" (BERNARDES DE MELLO, Marcos. Teoria do fato jurídico: plano da existência. 12.ed. São Paulo: Saraiva, 2003, p. 236-237).

${ }^{476}$ COELHO, Fábio Ulhoa Coelho. Curso de Direito Civil. vol1. São Paulo: Saraiva, 2003.

${ }^{477}$ Nesse sentido, Teresa Ancona Lopes afirma "[...] a função da boa-fé dentro da cláusula geral do abuso de direito é de correção ou limitação de condutas, tendo em vista os valores e a justiça que presidem o ordenamento jurídico. É uma de suas funções. Assim, apesar do abuso do direito quase sempre perpassar pelo
} 


\begin{abstract}
A boa-fé objetiva, regra jurídica de comportamento exigível na vida social, finalmente, 'após longo e tenebroso inverno', encontrou guarida no Código Civil brasileiro. Trata-se de proteção às expectativas criadas. Posta como norma de interpretação no art. 113 ('Os negócios jurídicos devem ser interpretados conforme a boa-fé e os usos do lugar de sua celebração'), encontra-se, também, sempre com o mesmo sentido, previsto como limite ao exercício de posições jurídicas, no art. 187, sobre o abuso de direito ('Também comete ato ilícito o titular de um direito que, ao exercê-lo, excede manifestamente os limites impostos pelo seu fim econômico ou social, pela boa-fé ou pelos bons costumes'). Está, ainda, como cláusula geral de criação de deveres no campo contratual, no art. 422 ('Os contratantes são obrigados a guardar, assim na conclusão do contrato, como em sua execução, os princípios de probidade e boafé'). Ora, também a boa-fé não é exclusiva do direito privado; aplica-se também no direito público, principalmente nas suas duas primeiras ocorrências [interpretação e limitação ao exercício inadmissível de posições jurídicas], que se encontram, aliás, na Parte Geral (são regras de Teoria Geral do Direito). ${ }^{478}$
\end{abstract}

Assim, tem-se que o exercício de um direito torna-se inadmissível quando, em determinado caso concreto, representa uma violação à boa-fé objetiva, seja porque o titular persegue um interesse não protegido, seja porque a proteção da contraparte mostra-se mais importante que a garantia daquele direito - isso significa dizer que o parâmetro para a configuração do abuso não é a intenção, mas a conduta do titular da posição jurídica: quando tal conduta se mostra desleal e desonesta ou viola a boa-fé objetiva, tem-se o abuso e a consequente restrição ou supressão do direito ${ }^{479}$.

E apesar de as noções de boa-fé e abuso de direito terem nascido no âmbito do direito obrigacional e de propriedade, com seu desenvolvimento se tornaram valores fundantes de todo o ordenamento jurídico, pelo que sua aplicação não pode ser negligenciada em nenhum ramo do direito - inclusive o processual. Se não há espaços no ordenamento jurídico livres dos direitos fundamentais - como pontuado por Canotilho ${ }^{480}$ também não há espaços em que se permita o exercício de direitos de forma abusiva, ou seja, aquém dos limites da boa-fé objetiva:

A aplicação do instituto do abuso de direito no campo do direito processual civil
surge, hoje, indiscutível. Nenhuma posição jurídico-subjetiva está imune a uma
sindicância, no momento de seu exercício, feita à luz dos valores fundamentais
do ordenamento em causa. Não há alternativa: o direito subjetivo imune ao

desrespeito à boa-fé, a ela não se iguala" (LOPES, Teresa Ancona. Exercício do direito e suas limitações: abuso do direito...Op. cit., p. 65).

478 JUNQUEIRA DE AZEVEDO, Antonio. Novos estudos e pareceres de direito privado. São Paulo: Saraiva, 2009, p. 25.

${ }^{479}$ FRITZ, Karina Nunes. Boa-fé objetiva na fase pré-contraual...Op. cit., p. 165-166.

${ }^{480} \mathrm{Cf}$. nota 429. 
sistema - e, como tal, suscetível de um exercício ilimitado - acabaria por se colocar fora do próprio ordenamento, tornando-se irreconhecível. ${ }^{481}$

Partindo desse princípio e tendo em vista que, enquanto parte em um processo, um sujeito de direito exercita uma posição jurídica subjetiva, é lícito dizer que tal exercício do direito de ação - deve ser balizado pelos critérios da lealdade e da boa-fé, sob pena de ser considerado inadmissível, especialmente no que toca à tutela dos direitos transindividuais - em que o escopo publicístico do processo resta definitivamente pronunciado, já que essa tutela foi idealizada justamente para permitir a judicialização de conflitos de um grande número de pessoas e, ainda, para servir como foro de participação direta da sociedade na discussão de temas que concernem à coletividade.

Fixadas essas premissas, passa-se à análise do abuso de direito praticado no âmbito processual, especialmente no que diz respeito ao abuso praticado pelo autor da demanda, configurando o abuso do direito de demandar, além de analisar de que forma a aferição ope judicis da representatividade adequada pode coibir esse tipo de abuso.

6.1.2.3. Abuso do direito de demandar: uma das facetas do abuso de direitos no âmbito do processo

Se a boa-fé, como dito, é um princípio fundante de todo o ordenamento jurídico pátrio, pode-se dizer que o comportamento das partes em juízo deve, também, ser orientado por ele. No âmbito processual, a atuação conforme a boa-fé é listada expressamente entre os deveres das partes, da lealdade processual ${ }^{482}$. O dever de lealdade processual preconiza a atuação das partes segundo parâmetros éticos e morais, sendo orientado por um ideal de justiça no processo ${ }^{483}$. Em outras palavras, tem a ver com (i) o respeito às "regras do jogo"; (ii) a existência de limites de ordem ética e legal impostos à conduta dos litigantes; e (iii) o fato de que existem outras garantias e liberdades a $\operatorname{preservar}^{484}$.

\footnotetext{
${ }^{481}$ MENEZES CORDEIRO, Antonio Manuel da Rocha. Litigância de má-fé, abuso do direito...Op. cit., p. 127.

${ }^{482}$ Artigo 14, inciso II - São deveres das partes e de todos aqueles que de qualquer forma participam do processo [...] proceder com lealdade e boa-fé.

${ }^{483}$ Citando o eminente doutrinador Enrico Tullio Liebman, é possível dizer que o dever de lealdade processual pode ser definido como os freios limitativos que a moral e os costumes impõem aos litigantes e a seus defensores. (LIEBMAN, Enrico Tullio. Manual de direito processual...Op. cit., p. 124).

${ }^{484}$ ABDO, Helena Najjar. O abuso do processo...Op. cit., p. 130.
} 
Uma das razões de ser do dever de lealdade processual - e seus desdobramentos, entre eles o dever de veracidade - é o escopo publicístico do processo: o Estado tem interesse no processo à medida que a atividade jurisdicional tem como objetivo a pacificação social ${ }^{485}$. As partes que faltam com o dever de lealdade frustram a expectativa do Estado de prestar a tutela jurisdicional de forma justa. Assim, por todos os ângulos, é possível depreender que o dever de lealdade processual é um dos fatores que possibilita a identificação do abuso do direito processual - especialmente quando, na conduta do agente, são observados os demais elementos estruturais do abuso.

Desenvolvendo a ideia acenada no tópico anterior, assim como pode ocorrer abuso de direito material, pode também haver abuso de direito no âmbito do processo. Dando contornos mais definidos ao conceito, destaca Helena Najjar Abdo que:

[...] da mesma forma como só se admite o abuso de direito quando o agente é titular de um determinado direito subjetivo, também só se pode admitir o abuso do processo quando o sujeito (núcleo da situação subjetiva) é o titular de uma posição processual (poder, dever, ônus ou faculdade). Caso contrário se esta diante de um ato ilícito e não de um ato abusivo ${ }^{486}$.

Ao longo do processo, as partes terão liberdade para exercer essas posições jurídicas subjetivas, segundo suas estratégias e sua conveniência, nos limites estabelecidos pela $1 \mathrm{ei}^{487}$. Problemas surgem, entretanto, quando a lei não prescreve um parâmetro determinado para a atuação da parte, deixando a ela um espaço de escolha, já que não bastará que tal escolha esteja de acordo ou não seja vedada pela lei - dicotomia legal/ilegal -, uma vez que essa escolha também deverá considerar a conduta justa/injusta, prejudicial/inofensiva, fraudulenta/honesta ${ }^{488}$.

Quando as partes podem escolher quanto a meios ou fins que se pretendem atingir com determinado ato processual, observa-se com maior frequência o desvio de finalidade e, por conseguinte, o abuso de direito no âmbito do processo. Em outras palavras, pode-se dizer que um sujeito de direito age abusivamente quando opta por utilizar determinado mecanismo processual para alcançar outros fins que não aqueles normalmente previstos

\footnotetext{
${ }^{485}$ Cf. nota 396.

${ }^{486}$ ABDO, Helena Najjar. O abuso do processo...Op. cit., p. 63.

${ }^{487}$ DINAMARCO, Cândido Rangel. Instituições de direito processual civil. vol 2. São Paulo: Malheiros, 2001, p. 226.

488 TARUFFO, Michelle. Abuso de direitos processuais: padrões comparativos de lealdade processual (relatório geral). Revista de Processo, São Paulo: RT 177, 2009, p. 162.
} 
para o respectivo meio ou instrumento utilizado ${ }^{489}$. Há que se observar que aos atos processuais foi atribuída forma determinada por se entender que essa era a melhor maneira do Estado prover a justiça, atuando através do processo. Assim, é facultado às partes fazer uso dos instrumentos processuais - mas ressalta-se que não é qualquer uso, devendo ser aquele cuja função ou finalidade foi positivada ou quista pelo legislador.

Observa-se que os elementos estruturais do abuso do direito processual - nos mesmos moldes do abuso de direito - são: (i) a titularidade, por parte do sujeito de direito, de uma posição jurídica processual (objeto do abuso); (ii) o exercício dessa posição jurídica de forma anômala, buscando finalidade diversa daquela pretendida pela lei ou pelo ordenamento jurídico; e (iii) a aparência de legalidade que decorre do uso livre, e garantido pela lei, das diferentes situações subjetivas processuais. O desvio de finalidade é, sem dúvida, a pedra de toque para a identificação do abuso do direito no âmbito processual, já que é ela que permite diferenciar o simples descumprimento das regras processuais do exercício impróprio, incorreto, anômalo de uma situação processual de titularidade do sujeito de direito ${ }^{490}$.

Há, ainda, alguns outros elementos que se podem tomar por base para a aferição das condutas abusivas, entre eles a falta de seriedade no ato, ou ilegitimidade do escopo visado pelo agente, à lesividade causada à administração da justiça e a presença de dolo ou culpa $^{491}$.

Tomando como ponto de partida essas primeiras linhas sobre o abuso do direito no âmbito processual, interessa abordar o abuso do direito de demandar. Esse tipo de conduta abusiva é identificada quando a parte autora vai a juízo e deduz pretensões de forma anômala, com desvio de finalidade. O abuso do direito de demandar, sob esse aspecto, pode ser caracterizado como abuso macroscópico do processo, já que o sujeito processual faz mau uso do processo como um todo, isto é, da tutela jurisdicional globalmente considerada $^{492}$.

Há especial embate em torno desse tipo de abuso, pois parece haver um temor generalizado, na doutrina e na jurisprudência, que sua inibição se converta em óbice à efetivação da garantia do acesso à justiça. Nesse sentido, a primeira ideia que se precisa superar - para que seja possível controlar, efetivamente, a conduta dos autores nos

\footnotetext{
${ }^{489}$ ABDO, Helena Najjar. O abuso do processo...Op. cit., p. 81.

490 TARUFFO, Michelle. Abuso de direitos processuais...Op. cit., p. 167.

${ }^{491}$ ABDO, Helena Najjar. O abuso do processo...Op. cit., p.94.

492 Ibid., p. 189.
} 
processos - é a de que haveria algum tipo de conflito entre a teoria do abuso de direito de demandar e a garantia do acesso a um provimento jurisdicional justo, ou da inafastabilidade do controle jurisdicional (artigo $5^{\circ}, \mathrm{XXXV}$ da Constituição Federal). É certo que não se pretende, com a identificação e punição das condutas abusivas dos autores, dificultar ou impedir o acesso à justiça, mas, simplesmente, qualificá-lo. A aplicação da teoria do abuso de direito teria como finalidade apenas repudiar o exercício anômalo de direito no âmbito do processo, que compreende entre suas hipóteses o direito de demandar ${ }^{493}$.

Em outras palavras, o exercício do direito de ação - como de qualquer outro direito - e a liberdade que gozam os sujeitos processuais são relativos e não absolutos, de modo que o exercício do poder de ação está limitado pela vedação ao exercício abusivo dessa posição jurídica processual ${ }^{494}$. Nas palavras de Michelle Taruffo, "a garantia termina quando o abuso começa"495.

E o abuso do direito de demandar perpetrado pelos autores pode estar expresso em diversas atitudes, relacionadas ao mérito da demanda ou mesmo às condições da ação, como, por exemplo, a legitimidade ativa. É, em geral, o desvio de finalidade que acaba por transformar uma situação de simples improcedência ou carência de ação em uma hipótese de abuso do direito de demandar; e as possibilidades de abuso são tantas quantas a criatividade humana permite.

Se é certo que o poder conferido aos indivíduos para intentar uma ação, como posição jurídica processual que é, pode ser objeto de exercício abusivo, também é certo que esse tipo de abuso pode ser cometido pelas entidades legitimadas extraordinariamente para a propositura de ações civis públicas em defesa dos direitos metaindividuais - em particular as associações civis.

E a aferição da representatividade adequada, em cada caso concreto, pelos juízes, é a principal forma encontrada para garantir que o abuso do direito de demandar será extirpado ou, ao menos, controlado efetivamente no âmbito das ações coletivas.

\footnotetext{
493 Ibid., p. 191.

${ }^{494}$ Ver "Abuso de direito processual no ordenamento jurídico brasileiro" (THEODORO JUNIOR, Humberto. In: MOREIRA, José Carlos Barbosa (coord.). Abuso dos Direitos Processuais. Rio de Janeiro: Editora Forense, 2000, p. 113).

${ }^{495}$ TARUFFO, Michelle. Abuso de direitos processuais...Op. cit., p. 165.
} 
6.1.2.4. O papel do juiz no controle do abuso do direito de demandar: a caracterização do ato abusivo só poderá ser apurada in concreto mediante a aferição da representatividade adequada

Partindo das premissas teóricas delineadas nos tópicos anteriores entende-se que a propositura de uma ação por uma associação civil só poderá ser caracterizada como abusiva - em virtude de desvio de finalidade para que se possibilite a propositura da ação coletiva, ou pela ampliação excessiva dos objetivos institucionais, como se verá a seguir na prática, pelo juiz da causa.

A representatividade adequada, por sua vez, já foi discutida detalhadamente neste estudo, tendo restado claro que ela se afasta da ideia de representação no sentido técnico e jurídico que a palavra tem em nosso ordenamento. O representante é aquele se postará em juízo para falar em nome de uma coletividade determinável ou não. Neste sentido, o representante adequado será aquele que tiver condições de defender de forma honesta e convincente o pensamento e os anseios de determinado grupo ou de toda a coletividade, dependendo do caso $^{496}$. Na definição de Ada Pellegrini Grinover esse instituto, um dos pilares do sistema dos direitos coletivos, exige:

[...] que o portador em juízo dos interesses ou direitos difusos, coletivos e individuais homogêneos apresente as necessárias condições de seriedade e idoneidade, até porque o legitimado é o sujeito do contraditório, do qual não participam diretamente os membros do grupo. ${ }^{497}$

O conceito de representatividade adequada carrega, portanto, ideias que vão desde a aptidão técnica, passando pela idoneidade e a seriedade, até a eficiência dos entes legitimados para a propositura das ações coletivas na representação da coletividade. A verificação da adequação do representante da coletividade nos processos coletivos vedaria o acesso ao judiciário de entidades que, entre outras coisas, não apresentassem seriedade e/ou idoneidade suficientes para a representação em juízo de determinado grupo, o que seria apurado por meio das atitudes desses autores em outros processos.

\footnotetext{
496 GIDI, Antonio. Representação adequada nas ações coletivas brasileiras: uma proposta. Revista de Processo, São Paulo:RT, n 108, p. 61-70, out/dez. 2002

497 Ver "Direito processual coletivo" (GRINOVER, Ada Pellegrini. In: LUCON, Paulo Henrique dos Santos (coord.). Tutela Coletiva: 20 anos da Lei de Ação Civil Pública e do Fundo de Direitos Difusos, 15 anos do Código de Defesa do Consumidor. São Paulo: Ed. RT, 2001, p. 306).
} 
Ou seja, negar a legitimidade ativa a tais entidades evitaria a promoção de demandas carentes de seriedade e/ou idoneidade - características que, ao lado do desvio de finalidade, se prestam a resguardar o devido processo legal e identificar os atos abusivos no âmbito do processo, dentre eles a própria propositura de demandas ${ }^{498}$. Nesse sentido, a aferição da representatividade adequada integraria o rol de medidas aptas a coibir o abuso do direito de demandar, sendo voltada especificamente para as demandas coletivas, em que a prática de condutas abusivas - e sua corrente impunidade - tem consequências deletérias para um número muito maior de pessoas e para o sistema dos processos coletivos em si.

O juiz pode realizar tal aferição independentemente de qualquer norma expressa autorizativa, conforme anteriormente mencionado, uma vez que sua atuação se prestará a eliminar condutas antijurídicas praticadas por instituições carentes de seriedade e/ou idoneidade. Dessa maneira, ressalte-se que o conceito de representatividade adequada enquanto meio para retirar a legitimidade ativa daquelas entidades que agem de forma desidiosa, inidônea ou movida por finalidades egoísticas - está intimamente ligado à ideia de repressão ao abuso de direito, já que tem basicamente o mesmo escopo.

Tendo isso em vista e partindo do fato de que grande parte da doutrina não aceita a aferição da representatividade adequada pelo juiz brasileiro, por entender que não há norma autorizativa para tanto ${ }^{499}$, nega-se, portanto, a possibilidade de controle ope judicis do referido requisito por parte do juiz, o que equivale a dizer que o magistrado precisa estar legalmente autorizado para poder coibir o abuso de direito no processo.

Ademais, há muito o processo deixou de ser enxergado apenas como um instrumento para que as partes busquem a efetivação de seus direitos de natureza privada. A concepção atual do processo coloca-o também, e primordialmente, como um mecanismo do Estado para promover a justiça, enquanto valor eminentemente social ${ }^{500}$. E essa predominância do escopo publicístico do processo, manifestada em inúmeros pontos da sistemática processual, está atrelada a uma postura ativa do juiz, que não poderá admitir

\footnotetext{
${ }^{498}$ Nesse sentido, Helena Najjar Abdo, ao tratar dos critérios suplementares ao desvio de finalidade na identificação de condutas abusivas: "São eles a falta de seriedade no ato, a ilicitude ou ilegitimidade do escopo visado pelo agente, a lesividade causada à administração da Justiça e a presença de dolo ou culpa" (ABDO, Helena Najjar. O abuso do processo...Op. cit., p. 94).

${ }^{499}$ Segundo grande parte da doutrina pátria, a aferição ope judicis da representatividade adequada estaria vedada no ordenamento jurídico pátrio em virtude de não estar prevista em lei tal possibilidade, conforme Capítulo 6, subitens 6.1 e 6.1.1.

${ }^{500}$ Ver "Dimensiones Sociales del Processo Civil" (MOREIRA, José Carlos Barbosa. Temas de Direito Processual Civil. $4^{\text {a }}$ Série. São Paulo: Saraiva, 1989, p. 26).
} 
que interesses privados suplantem ou interfiram nessa faceta pública que tem, em última análise, o objetivo da realização da justiça.

A exemplo disso, o próprio Código de Processo Civil estabelece, como dever primário do juiz, a ser exercitado a qualquer tempo, a prevenção de condutas contrárias à dignidade da justiça ${ }^{501}$, além de preconizar que deverá o magistrado combater atos colusivos, entre as partes, que visem à consecução de objetivos vedados pela lei ${ }^{502}$. Enquanto na primeira disposição se enquadra a maioria dos atos de abuso do direito processual - entre eles, no caso das associações, a propositura de ações com finalidades egoísticas e sem a seriedade que delas se espera na tutela de interesses da coletividade -, a segunda explicita situação que, na doutrina e jurisprudência norte-americanas acerca das Class Actions, é exemplo clássico de ausência de representatividade adequada, conquanto não seja a única modalidade de abuso ${ }^{503}$.

Além disso, o ordenamento jurídico conta com uma série de dispositivos que têm a finalidade de garantir que o juiz tenha autonomia suficiente para analisar - no caso concreto - as atitudes das partes, com o objetivo de vedar condutas abusivas. É o caso, por exemplo, do artigo 18 - que impõe ao juiz reconhecer e coibir, de ofício, a litigância de má-fé - e do artigo 130 - que fala no controle de condutas meramente protelatórias.

De uma forma geral, portanto, o juiz terá o poder e o dever de controlar as condutas abusivas praticadas pelas partes no processo, estando legalmente habilitado para tanto. E as previsões legais que autorizam esse controle - entre as quais se encontram as supracitadas

501 Artigo 125. O juiz dirigirá o processo conforme as disposições deste Código, competindo-lhe: III prevenir ou reprimir qualquer ato contrário à dignidade da Justiça.

502 Artigo 129. Convencendo-se, pelas circunstâncias da causa, de que autor e réu se serviram do processo para praticar ato simulado ou conseguir fim proibido por lei, o juiz proferirá sentença que obste aos objetivos das partes.

${ }^{503}$ Práticas de colusão entre representantes de coletividades autoras de class actions e os réus nas indigitadas ações são reportadas como uma das grandes preocupações dos estudiosos do tema nos Estados Unidos. Tais práticas são observadas com frequência na fase conhecida como pretrial, em que o ordenamento jurídico americano autoriza a transação entre a classe e os réus. Não é raro que os representantes, atendendo a interesses pessoais, façam acordos com os réus - em detrimento dos interesses da classe - e mesmo que exista colusão no momento da propositura da ação - visando a realização de um acordo que o réu possa opor como justificativa acaso outras pessoas reclamem o mesmo direito. Tais práticas levaram à inclusão, entre os requisitos para a aferição da adequacy of representation, da ausência de conflito de interesses entre o grupo e o representante (The proposed class representative has interests that are in conflict with or antagonistic to other class members). Nesse sentido ver MULLENIX, Linda. Taking adequacy seriously: the inadequate assessment of adequacy in litigation and settlement classes....Op. cit., p. 1704-1705. É certo que o sistema brasileiro, ao vedar a possibilidade de transação entre as partes nas ações coletivas e estabelecer que a coisa julgada por ausência de provas não obstará a propositura de novas ações coletivas sobre o mesmo tema (Artigo 103, I do Código de Defesa do Consumidor), cria um sistema de proteção contra atos dessa natureza. Tal sistema, entretanto, não é eficiente para todos os casos, já que a desídia do representante da classe resulte ela de ato de colusão ou não - pode implicar em uma sentença de improcedência que vede a repropositura da ação e prejudique a classe em alguma medida ou, ainda, que se consolide como precedente negativo que pode mesmo prejudicar as ações individuais. 
- são propositalmente abertas e abrangentes pois, como bem já se observou, as hipóteses de abuso são tantas quantas permitir a criatividade humana, e seu caráter abusivo só poderá ser apurado no caso concreto ${ }^{504}$. É o papel ativo a que se chama o juiz no processo civil contemporâneo, o que tem importância capital no processo coletivo ${ }^{505}$.

Se está habilitado a controlar práticas abusivas no âmbito do processo, e se a aferição da representatividade adequada se presta justamente a afastar a legitimidade de autores inidôneos - que propõem e conduzem processos sem seriedade, de forma desidiosa ou buscando finalidades alheias àquelas a que se prestam os processos coletivos -, a conclusão lógica é que os juízes podem, sim, pela via do controle ao abuso do direito de demandar, aferir a representatividade adequada das associações cíveis no âmbito do processo coletivo.

E isso sem que se afigure necessária a existência de uma prescrição normativa específica acerca dessa possibilidade ou dos parâmetros para que ela seja feita parâmetros estes geralmente estabelecidos em um rol de atitudes que seriam consideradas típicas de um representante inadequado. Conquanto a positivação dessa possibilidade e desses parâmetros seja desejável, acredita-se que o ordenamento jurídico brasileiro está devidamente equipado com os meios necessários para a repressão de condutas que se classificam como abuso do direito de demandar das associações civis e, via de consequência, para a aferição da representatividade adequada dessas entidades.

É possível afirmar que, em um cenário em que os juízes pudessem observar que a conduta da parte autora, ao intentar o processo, está marcada primordialmente pelo desvio de finalidade e, diante disso, - no caso dos processos coletivos - pudessem extinguir essa demanda por falta de representatividade adequada, não haveria a necessidade de novos

\footnotetext{
${ }^{504}$ Antonio Menezes Cordeiro, ao tratar de um dos principais casos de abuso de direito, a supressio (Verwirkungdo no direito alemão), assinala que a caracterização da conduta como abusiva só poderá ser feita através de um juízo de valor externo: "O quantum do não-exercício será determinado pelas circunstâncias do caso[...]". Retoma o tema ao dizer que o abuso do direito não pode se restringir a análises racionalistas, pois exigem valoração e um atendimento ao poder dos factos (MENEZES CORDEIRO, Antonio Manuel da Rocha. Litigância de má-fé, abuso do direito...Op. cit., p. 100 e 121).

${ }^{505}$ Nas palavras de Carlos Alberto Álvaro de Oliveira, não se pretende que o juiz tenha um papel superior ao das partes, mas que seja legitimado a exercer a jurisdição de modo mais eficiente, buscando um equilíbrio entre os poderes a ele conferidos e aqueles atribuídos às partes, para que se atinja um maior grau de justiça nas decisões (OLIVEIRA, Carlos Alberto Alvaro de. Efetividade e processo de conhecimento. Revista da Faculdade de Direito da Universidade Federal do Rio Grande do Sul, Porto Alegre, n.16, 1999, p.7-19). Sobre a importância da participação ativa do juiz no processo coletivo ver GRINOVER, Ada Pellegrini. A tutela jurisdicional dos interesses difusos. In: GRINOVER, Ada Pellegrini. Novas Tendências do Direito Processual Civil. Rio de Janeiro: Forense Universitária, $2^{\text {a }}$ ed., 1990, p.137-143 e BUENO, Cassio Scapinella. As class actions norte-americanas e as ações coletivas brasileiras: pontos para uma reflexão conjunta...Op. cit., p. 144-145.
} 
dispositivos legais com o objetivo de coibir tais atos abusivos e retirar a legitimidade daqueles que não representam de forma satisfatória os interesses da coletividade.

Considerando o que se expôs, a possibilidade do controle jurisdicional da representatividade adequada é possível em nosso sistema jurídico independentemente de previsão legal expressa. Além disso, o sistema eleito em nosso ordenamento, no que toca aos limites subjetivos da coisa julgada no processo coletivo - que procurou criar uma rede de proteção aos titulares do direito defendido pela via coletiva -, é suficiente, sozinho, para evitar os danos causados pelas condutas de um representante inadequado.

Esse estudo não considera que a criação de um sistema especial no que tange aos limites subjetivos da coisa julgada - secundum eventum litis e secundum eventum probationem nas demandas que tutelam direito coletivos e difusos - é suficiente para dispensar a aferição da representatividade adequada ${ }^{506}$. Na ausência de previsão específica da necessidade do escrutínio desse conceito, indispensável para garantir o devido processo legal, procurou-se criar uma rede de proteção aos titulares do direito defendido pela via coletiva, de modo que a coisa julgada só se formará se beneficiar os substituídos ou se a sentença for de improcedência calcada em provas suficientes para a análise do mérito. Em qualquer situação, não haverá prejuízo aos direitos individuais ${ }^{507}$.

No que tange às ações em defesa dos direitos difusos e coletivos, a sistemática da coisa julgada está prevista nos incisos I e II do artigo 103 do Código de Defesa do Consumidor. A coisa julgada, nesses processos, só não atingirá a coletividade ou grupo, cujos direitos são defendidos, em caso de improcedência por insuficiência de provas. Assim, a proteção ao grupo pelo sistema da coisa julgada só se dá aos casos em que o representante não foi capaz de produzir provas suficientes para fundamentar a procedência do pedido - caso em que a demanda poderia ser proposta novamente. Entretanto, é cediço que a deficiência na instrução probatória não é o único fator que pode conduzir à improcedência da demanda. Em outras palavras, se a representação deficiente se dá na condução do processo, ou mesmo na fundamentação da pretensão do grupo, levando à prolação de uma sentença de improcedência - mesmo com material probatório suficiente

\footnotetext{
${ }^{506}$ Sobre o tema, ver VIOLIN, Jordão. Ação Coletiva Passiva, fundamentos e perfis. Salvador: Ed. JusPodium, 2008, p.66-70.

${ }^{507}$ Ver "O controle judicial da representatividade adequada: uma análise do sistema norte-americano e brasileiro" (COSTA, Susana Henriques. In: Carlos Alberto de Salles (coord.). As grandes transformações do processo civil brasileiro - estudos em homenagem ao professor Kazuo Watanabe. São Paulo: Quartier Latin: 2009, p. 967).
} 
nos autos -, forma-se coisa julgada que impede a nova propositura da mesma demanda coletiva $^{508} \mathrm{e}^{509}$.

Ademais, mesmo tendo o Código de Defesa do Consumidor se preocupado em resguardar os direitos individuais, prevendo que a coisa julgada na ação coletiva não prejudicará tais direitos - mantendo incólume a possibilidade de ajuizamento de ações individuais pelos interessados em casos tanto de direitos difusos, coletivos ou individuais homogêneos -, acreditar que isso basta para afastar a necessidade de se aferir a representatividade adequada do legitimado ativo vai contra a própria lógica do sistema de proteção aos direitos metaindividuais, que visa possibilitar uma tutela jurisdicional mais eficiente e que evite a atomização dos conflitos.

O impacto de uma sentença de improcedência em uma ação coletiva, que poderia ter sido procedente e beneficiado todo um grupo de interessados se o representante tivesse defendido adequadamente os interesses em jogo, pode desencadear a propositura de milhares de ações individuais, esvaziando as ações coletivas de uma de suas principais vantagens: a de evitar a propositura de diversas demandas sobre o mesmo tema. Mais do que isso, a falta de controle sobre a atuação dos legitimados ativos acaba por minar a própria confiança no sistema dos processos coletivos, uma vez que sem a certeza de uma representação vigorosa e pautada pela técnica - com reais chances de resultar em uma sentença de procedência que possa vir a ser executada no futuro -, os indivíduos podem se ver obrigados a propor suas ações individuais para preservar os direitos discutidos ${ }^{510}$.

\footnotetext{
${ }^{508}$ É o que se extrai dos incisos do artigo 103 do Código de Defesa do Consumidor: Nas ações coletivas de que trata este código, a sentença fará coisa julgada: I - erga omnes, exceto se o pedido for julgado improcedente por insuficiência de provas, hipótese em que qualquer legitimado poderá intentar outra ação, com idêntico fundamento valendo-se de nova prova, na hipótese do inciso I do parágrafo único do art. 81; II ultra partes, mas limitadamente ao grupo, categoria ou classe, salvo improcedência por insuficiência de provas, nos termos do inciso anterior, quando se tratar da hipótese prevista no inciso II do parágrafo único do art. 81; III - erga omnes, apenas no caso de procedência do pedido, para beneficiar todas as vítimas e seus sucessores, na hipótese do inciso III do parágrafo único do art. 81. $§ 1^{\circ}$ Os efeitos da coisa julgada previstos nos incisos I e II não prejudicarão interesses e direitos individuais dos integrantes da coletividade, do grupo, categoria ou classe. $\S 2^{\circ} \mathrm{Na}$ hipótese prevista no inciso III, em caso de improcedência do pedido, os interessados que não tiverem intervindo no processo como litisconsortes poderão propor ação de indenização a título individual. Ver, GRINOVER, Ada Pellegrini; WATANABE, Kazuo; NERY JR., Nelson. Código Brasileiro de Defesa do Consumidor comentado pelos autores do anteprojeto...Op. cit., p. 184-208. ${ }^{509}$ COSTA, Susana Henriques. O controle judicial da representatividade adequada...Op. cit., p. 975.

${ }^{510}$ Há divergência na doutrina e na jurisprudência quanto à interrupção do prazo prescricional das ações individuais na pendência de uma ação coletiva sobre o mesmo tema, uma vez que não existe previsão expressa na Lei da Ação Civil Pública ou no Código de Defesa do Consumidor acerca deste assunto. Elton Venturi pontua que, ao se aplicar o artigo 104 do Código de Defesa do Consumidor, é certo que não flui o prazo prescricional para a ação individual, se a coletiva vier a ser julgada improcedente por falta de provas ou extinta sem julgamento do mérito. Essa situação, entretanto, preconiza não só que a ação individual já tenha sido proposta como também que o titular do direito tenha expressamente se manifestado no sentido de suspender o andamento de sua ação até o julgamento da ação coletiva. Não resolve, portanto, o problema
} 
Susana Henriques da Costa ressalta, também, que independentemente do sistema da coisa julgada eleito por osso legislador, a aferição da representatividade adequada é o meio que melhor permite a consecussão dos objetivos do processo coletivos e que melhor se adequa aos objetivos do processo civil moderno:

\begin{abstract}
Levando-se em conta argumentos de produção, ou seja, de economia interna do processo, a saída da coisa julgada secundum eventum litis e secundum probationem nem sempre será adequada. Deixar que a máquina judiciária seja movimentada e despenda tempo e recursos em um processo coletivo ajuizado por ente não comprometido com $\mathrm{o}$ interesse em jogo, somente sob o argumento de que a demanda coletiva eventualmente poderá ser reproposta caso haja novas provas, não parece ser o mais racional. Sem dúvida alguma, melhor solução é possibilitar ao juiz o controle do real potencial representativo do autor e evitar a demanda coletiva inidônea. [...]

Sob todos os pontos de vista, portanto, o controle judicial da representatividade adequada se mostra melhor e mais efetivo. Sendo a efetividade o móvel do processo civil moderno, não há por que negar a possobilidade de o juiz apreciar a aptidão do legitimado coletivo em represenetar os membros ausentes da relação jurídica processual. ${ }^{511}$
\end{abstract}

Daí decorre que a existência da previsão legal que impeça, em alguns casos, o prejuízo dos direitos individuais frente à prolação de uma sentença de improcedência não é suficiente para garantir que o processo coletivo atinja suas finalidades vez que, como ressaltado, a improcedência de uma ação coletiva tem o condão de gerar efeitos que colocam em cheque alguns dos mais importantes objetivos do microssistema de tutela dos interesses transindividuais: a diminuição da litigiosidade e o aumento da segurança jurídica ao diminuir a chance de decisões contraditórias para questões idênticas ou análogas.

Por qualquer ângulo de análise, é possível concluir nessa primeira parte do estudo que a aferição da representatividade adequada por parte do juiz em nosso ordenamento jurídico não apenas é possível, como também se faz necessária e desejável. Não depende de positivação infraconstitucional, porquanto a garantia de que o representante da coletividade atue no processo com o maior vigor, seriedade e idoneidade possíveis é a

daquele que resolve esperar pelo resultado da ação coletiva sem propor uma ação individual veiculando a citada pretensão. Ver, nesse sentido, VENTURI, Elton. Processo civil coletivo: A tutela jurisdicional dos direitos difusos, coletivos e individuais homogêneos no Brasil. Perspectivas de um Código Brasileiro de Processos Coletivos. São Paulo: Malheiros, 2007, p. 369-371.

Há alguma jurisprudência no sentido de que existe interrupção da prescrição nas ações individuais enquanto pendente o processo coletivo, entretanto, não é possível dizer que há uma tendência definitiva nesse sentido, porquanto a matéria tenha sido analisada poucas vezes, e a jurisprudência dos Tribunais Superiores ainda seja omissa a esse respeito. Ver TRF $4^{\circ}$ APELAÇÃO CIVEL no 2007.70.01.005360-5, QUINTA TURMA, Rel. RÔMULO PIZZOLATTI, D.E. 12/08/2008.

${ }^{511}$ COSTA, Susana Henriques. O controle judicial da representatividade adequada...Op. Cit., p. 974-975. 
única forma de assegurar o devido processo legal nos processos coletivos, os quais, como garantia constitucional e direito fundamental que são, podem ser opostos de forma imediata contra o Estado e os seus representantes. O juiz, como representante do Estado, tem o dever de garantir a efetivação dos direitos fundamentais, preservar a boa-fé e evitar o abuso de direito, pelo que, em última análise, não há escusa para que se permita a propositura e a condução de uma demanda por quem não seja um representante adequado.

Em vista do exposto, passar-se-á à discussão das formas através das quais o controle ope judicis da representatividade adequada pode ser realizado no país, estudando quais elementos os juízes podem se valer para realizar esse escrutínio, especialmente quando se tratam das associações no polo ativo das demandas coletivas. Muitas das normas que tornam possível essa aferição já estão positivadas no ordenamento jurídico brasileiro basta que se lhes dê uma interpretação completa e sistemática, que se saia da superfície dos institutos e atinja as minúcias das relações jurídicas e situações fáticas que lhes deram causa. Uma atuação jurisdicional pautada pela preservação da boa-fé no processo e guiada pelo escopo maior, traçado em nossa Constituição, de preservar a incolumidade das esferas jurídicas dos indivíduos mediante o respeito ao devido processo legal, acabará resultando automaticamente em um controle da representatividade adequada dos autores coletivos.

Deve-se ter em mente que, especialmente em um cenário no qual aqueles que sofrerão os efeitos da sentença não estão presentes no processo para defender seus interesses, uma postura ativa do magistrado, a fim de garantir a mais ampla e irrestrita proteção a esses indivíduos é tudo, menos opcional.

\subsection{FORMAS DE CONTROLE JURISDICIONAL DA REPRESENTATIVIDADE ADEQUADA: CONDUTAS ABUSIVAS DAS ASSOCIAÇÕES E COMO COIBI- LAS}

Conforme discutido no capítulo anterior, esse estudo se alinha à corrente doutrinária que acredita na possibilidade de aferição da representatividade adequada das associações civis - enquanto autoras de ações coletivas - pelos juízes no caso concreto, sem a necessidade da positivação de uma norma que os autorize a fazê-lo, ou tampouco liste parâmetros para tal. Acredita-se que as normas existentes no ordenamento jurídico brasileiro, atualmente, já possibilitam esse controle. 
A corrente doutrinária que defende a possibilidade do controle jurisdicional é composta por alguns nomes expressivos, entre eles Ada Pellegrini Grinover, Kazuo Watanabe, Cássio Scarpinella Bueno, Antonio Gidi e Pedro Lenza, alguns deles citados anteriormente pelo fato de considerarem que a necessidade de se garantir o devido processo legal já é o suficiente para justificar essa aferição ${ }^{512}$. Cabe, no entanto, refletir sobre o pensamento de Ada Pellegrini Grinover, a qual justifica a possibilidade de controle da representatividade adequada, já que a necessidade dessa verificação decorrer do devido processo legal e, também, é admitido pela legislação infraconstitucional, quando esta é analisada de forma sistêmica.

No entender da doutrinadora, o sistema processual brasileiro não veda o controle da representatividade adequada, citando inclusive o caso das associações, aqui apreciado. Em suas próprias palavras:

[...] problemas práticos têm surgido pelo manejo de ações coletivas por parte de associações que, embora obedeçam os requisitos legais, não apresentam a credibilidade, a seriedade, o conhecimento técnico-científico, a capacidade econômica, a possibilidade de produzir uma defesa processual válida, dados sensíveis esses que constituem as características de uma 'representatividade' idônea e adequada. [...]

Para casos como esse, é que seria de grande valia reconhecer ao juiz o controle sobre a legitimação, em cada caso concreto, de modo a possibilitar a inadmissibilidade da ação coletiva, quando a 'representatividade' do legitimado se mostrar inadequada.

Quer me parecer que o sistema brasileiro, embora não o afirme expressamente, não é avesso ao controle da 'representatividade adequada' pelo juiz, em cada caso concreto.

$\mathrm{O}$ art. $82, \S 1^{\circ}$ do Código de Defesa do Consumidor permite ao juiz dispensar a associação do requisito da pré-constituição há pelo menos um ano, quando haja manifesto interesse social evidenciado pela dimensão ou característica do dano, ou pela relevância do bem jurídico a ser protegido. A análise atribuída ao juiz no caso concreto, para o reconhecimento da legitimação, está muito próxima do exame da 'representatividade adequada', podendo-se afirmar que, a contrario sensu, o juiz pode negar a referida legitimação, quando entender não presentes os requisitos da adequação. [...]

Vê-se daí que o ordenamento brasileiro não é infenso ao controle da legitimação ope judicis, de modo que se pode afirmar que o modelo do direito comparado, que atribui ao juiz o controle da 'representatividade adequada' (Estados Unidos

\footnotetext{
${ }^{512}$ Antonio Gidi e Cássio Scarpinella Bueno, conforme notas 436 e 437, entendem que a necessidade de garantir o devido processo legal basta para que o juiz possa aferir a representatividade adequada. Este último, assevera sobre o tema: "Não pode, portanto, o legislador pretender criar, com foros de definitividade, padrões de legitimação - seja a que título for - sendo sempre possível ao juiz, em cada caso concreto, constatar o comando abstrato da norma com os valores do devido processo legal constitucionalmente assegurado antes de determinar o processamento de determinada ação como coletiva. Não condiz com o espírito da Constituição a presunção legislativa de representantes adequados a título de portadores de afirmações de direitos dos membros ausentes da relação processual”. (BUENO, Cássio Scarpinella. As class actions norteamericanas e as ações coletivas brasileiras: pontos para uma reflexão conjunta. Revista de Processo, São Paulo: Revista dos Tribunais, v. 82, 1996 p. 142)
} 
da América, Código Modelo para a Ibéro-América, Uruguai e Argentina), pode ser tranquilamente adotado no Brasil na ausência de norma impeditiva. ${ }^{513}$

De acordo com o pensamento da doutrinadora, ainda no campo da análise da possibilidade do controle da representatividade dos legitimados ativos, se o sistema permite que o juiz realize uma análise casuística para garantir a legitimidade às associações - no caso podendo dispensar o requisito da pré-constituição há um ano -, permitiria também a verificação da atuação dessas entidades para, então, negar-lhes a legitimação, caso se apure a falta de seriedade, idoneidade ou compromisso com os objetivos da classe defendida. Essa visão parte da ideia que os requisitos para atribuição de legitimidade ativa às associações - a constituição há mais de um ano e a inclusão dos direitos defendidos entre suas finalidades institucionais - podem servir como base para a aferição da representatividade adequada, demandando-se apenas uma melhor análise de cada caso concreto pelo juiz.

Esse estudo se alinha ao quanto exposto por Ada Pellegrini Grinover no texto supracitado que, com base no que aqui se expôs, completa a ideia de que a aferição da representatividade adequada é desejável e possível no ordenamento jurídico pátrio conquanto não esteja prevista expressamente. Entretanto, pretende-se ampliar a análise das formas como tal controle pode ser realizado pelos magistrados. E essa análise será feita justamente pela via dos requisitos para atribuição da legitimidade ativa às associações, que devem ser vistos não como limitadores para a verificação da adequação do representante, mas como parâmetros a serem utilizados pelos juízes quando interpretados de acordo com as garantias constitucionais e com as cláusulas gerais do direito.

Assim, se a dispensa da pré-constituição há um ano, pelo juiz, de acordo com critérios atinentes ao caso concreto, é um indicativo da possibilidade de controle jurisdicional da representatividade adequada, essa adequação pode ser medida em cada ação coletiva movida por entidade associativa analisando-se os demais critérios de atribuição da legitimidade, quais sejam: (i) a caracterização da entidade como associação enquanto litigante ideológico e sem finalidades lucrativas; e (ii) a pertinência temática entre o direito defendido em juízo e os objetivos declinados em estatuto. Para tanto, basta que se saia da interpretação superficial desses dispositivos, conforme anteriormente assinalado. É o que se pretende analisar a seguir.

513 GRINOVER, Ada Pellegrini; WATANABE, Kazuo; NERY JUNIOR, Nelson. Código Brasileiro de Defesa do Consumidor comentado pelos autores do anteprojeto...Op. cit.,. 98. 


\subsubsection{Interpretação conjunta do Código Civil e do Código de Defesa do Consumidor para identificar as reais associações}

Muito embora a maioria da doutrina e da jurisprudência pátrias dirija o foco de sua análise acerca da legitimidade das associações (e mesmo de uma eventual aferição da representatividade adequada dessas entidades na propositura de ações coletivas) para os requisitos descritos no inciso IV do artigo 82 do Código de Defesa do Consumidor - a préconstituição há um ano e a inclusão dos direitos pleiteados entre as finalidades institucionais, negligencia-se, no entanto, um primeiro requisito: a caracterização da entidade autora como associação.

Antes de prever qualquer requisito, o artigo 82, IV do diploma consumerista - e antes dele o artigo $5^{\circ}, \mathrm{V}$ da Lei da Ação Civil Pública (Lei n ${ }^{\circ}$ 7.347/1985) - determinou que a legitimada será uma associação. O legislador afastou, portanto, outras pessoas jurídicas, como as sociedades e as fundações ${ }^{514}$, do polo ativo das demandas coletivas, o que tem um sentido perceptível. As associações, desde a sua gênese, que data das corporações de ofício medievais, sempre puderam ser traduzidas como um centro de agregação de pessoas visando a defesa de interesses comuns ${ }^{515}$. Atualmente, essa defesa é marcada por caracteres ideológicos, desvinculados da persecução de lucro.

A opção do legislador por legitimar especificamente as associações - em detrimento da legitimação individual, por exemplo - se deu com vistas a assegurar à sociedade civil a participação direta na defesa dos interesses coletivos, considerando que um grupo de pessoas que se reúnem para defender determinados objetivos teria mais aptidão para fazê-lo em juízo do que os cidadãos individualmente considerados. Ademais, a existência de diversas pessoas na mesma associação, em busca de um fim comum, funcionaria como uma forma de fiscalização mútua para coibir atos praticados com finalidades egoísticas, fora do objeto da entidade ${ }^{516}$.

\footnotetext{
${ }^{514}$ As diferenças entre as pessoas jurídicas descritas pelo Código Civil - notadamente associações, fundações e sociedades - foram esmiuçadas no capítulo 5, subitem 3.4 .

${ }^{515}$ LEONARDO, Rodrigo Xavier. As associações em sentido estrito...Op. cit., p. 63.

516 Sobre o receio de se atribuir legitimidade individual pontua Kazuo Watanabe: "Pelas regras que disciplinam as obrigações indivisíveis, seria admissível, em linha de princípio, a legitimação concorrente de todos os indivíduos para a defesa dos interesses difusos ou coletivos de natureza indivisível. Mas ponderações várias, como as pertinentes ao conteúdo político das demandas, à possibilidade de pressões quanto à propositura e prosseguimento da demanda, à produção de provas adequadas e ao prosseguimento destemido nas instâncias superiores, e à necessidade, enfim, de um fortalecimento do autor da demanda coletiva, fizeram com que se excluísse a legitimação individual para a tutela dos consumidores a título coletivo" (GRINOVER, Ada Pellegrini; WATANABE, Kazuo; NERY JUNIOR, Nelson. Código Brasileiro
} 
É, portanto, característica intrínseca às entidades associativas que seu objetivo seja a defesa de determinadas ideias, bem como a proteção de uma série de princípios comuns a todos os seus associados. Foi esse o motivo primordial pelo qual se atribuiu legitimidade ativa a essas entidades, uma vez que elas se prestariam naturalmente à defesa de uma determinada coletividade, e, como estão alijadas legalmente da possibilidade de buscar o lucro, estariam menos propensas a perseguir objetivos individuais ou que só interessassem a uma pequena parcela do grupo ${ }^{517}$.

Essa regra que veda a persecução de fins lucrativos pelas associações está positivada no artigo 53 do Código Civil, que passou a tratar as associações como subtipo normativo fechado, caracterizado como uma união de pessoas organizada para o desenvolvimento de finalidades não econômicas. Assim, a busca de fins não econômicos é o quid caracterizador das associações. A esse respeito, Rodrigo Xavier Leonardo esclarece que "[...] se, para caracterizar o subtipo das sociedades, o legislador flagrantemente fixou os dados referentes ao objeto e ao escopo, no que diz respeito ao subtipo das associações em sentido estrito, sua caracterização se dá meramente pelo escopo sob uma perspectiva negativa, qual seja, a busca de 'fins não econômicos' (art. 53, caput, do CCB)."

Os artigos que vão do 54 ao 60 do Código Civil ${ }^{519}$, que regulamentam a constituição, organização e manutenção das entidades associativas, por sua vez, também são indispensáveis para que se chegue à conclusão de que uma determinada pessoa jurídica é ou não uma associação em sentido estrito - aquela que está legitimada para a propositura de ações coletivas.

Como restou delimitado no capítulo 3, para que uma organização possa ser considerada uma associação, deverá ser constituída por meio de um negócio jurídico

de Defesa do Consumidor comentado pelos autores do anteprojeto...Op. cit., p. 84). O mesmo autor, em outro trecho da mesma obra, exalta a necessidade de fortalecer a sociedade civil ao falar da legitimidade das associações: "Os consumidores não poderão confiar apenas no paternalismo do Estado. É necessário que a própria sociedade se estruture melhor e participe ativamente da defesa dos interesses de seus membros, fazendo com que a nova mentalidade que disso resulte, pela formação de uma sociedade mais solidária (art. $3^{\circ}, \mathrm{I}, \mathrm{CF}$ ), seja a grande protetora de todos os consumidores" (Ibid., p. 94).

${ }^{517}$ LEONARDO, Rodrigo Xavier. As associações em sentido estrito...Op. cit, p. 194 e 209-210.

${ }^{518}$ Ibid., p. 112.

${ }^{519}$ Assim como anteriormente destacado no capítulo 3, o artigo 54 do Código Civil dispõe sobre os requisitos mínimos do estatuto da associação, ao passo que os artigos 55 a 58 descrevem direitos e deveres dos associados. Já os artigos 59 e 60 regulam as atribuições da assembleia geral e regras concernentes à dissolução da pessoa jurídica. 
associativo, por duas ou mais pessoas ${ }^{520}$, que devem se organizar em órgãos deliberativos e diretivos, e visar à consecução de um fim comum declinado em estatuto, fim este que não pode ser econômico. Se a estas características se somar a constituição há mais de um ano, a associação será apta para ir a juízo na defesa dos interesses difusos, coletivos e individuais homogêneos - de seus associados e de toda a sociedade.

Em outras palavras, se essas regras dispostas no Código Civil forem interpretadas em conjunto com o Código de Defesa do Consumidor e com a Lei da Ação Civil Pública, podem se prestar a retirar a legitimidade de associações que não possam ser consideradas como "constituídas na forma da lei" e que, com isso, sequer possam ser consideradas associações. Serão alijadas da possibilidade de ir a juízo as associações mal constituídas ou seja, aquelas às quais faltar capacidade técnica, seriedade e/ou idoneidade - e, ainda, aquelas que abusem da forma associativa visando atingir fins egoísticos. Isto é, aquelas às quais faltar representatividade adequada.

Em primeiro plano, para ser considerada uma associação, o estatuto deverá se enquadrar nos ditames do artigo 54 do Código Civil, já que é o teor desse documento que dará aos sócios e a terceiros ${ }^{521}$ o conhecimento do funcionamento da entidade. Assim, o estatuto terá uma dupla função, visto que servirá para informar plenamente os integrantes da associação acerca das regras que regularão o relacionamento entre os associados e, ainda, para dar conhecimento a terceiros das características indispensáveis a entidade para a prática de atos da vida civil.

Deve estar bem claro a todos os associados: (i) o modo de constituição e funcionamento dos órgãos deliberativos (artigo 54, V do Código Civil) - para que possam eventualmente integrar tais órgãos e interferir diretamente na vida das associações; e (ii) a forma como esses associados serão aceitos na entidade e excluídos dela - de modo que tais decisões não fiquem ao arbítrio de determinado grupo de sócios ou de algum órgão diretivo. Se essas regras não forem atendidas pelo estatuto social das entidades associativas - ou, mesmo que declinadas no estatuto, não sejam observadas na prática -, poderá se dizer que as associações não estão constituídas na forma da lei civil e não possuem legitimidade ativa para a promoção de ações em defesa da coletividade.

\footnotetext{
${ }^{520}$ Esse estudo se alinha à corrente que defende que a caracterização de uma organização como associação civil não depende de registro e, consequentemente, de personificação. Cf. nota 166.

${ }^{521}$ Esses terceiros podem tomar conhecimento do teor dos estatutos consultando os cartórios de registro civil, quando as associações forem registradas. No entanto, ainda que os estatutos não tenham sido levados a registro, eles poderão ter contato com esses estatutos quando do ajuizamento da ação coletiva pela associação.
} 
Até porque, em casos como esses, feridos os requisitos estatutários que deixam claro de que forma a associação é gerida, como os associados podem intervir na dinâmica social e, ainda, de que maneira podem exercer sua defesa em caso de exclusão, observarse-á uma desmedida ascendência de um determinado grupo de associados - geralmente integrantes dos quadros diretivos ou fundadores da entidade - sobre os demais, o que não pode ser admitido diante da previsão de que todos os associados devem ter iguais direitos (artigo 55 do Código Civil). E esse é apenas um dos exemplos que podem ser aferidos no caso concreto.

Observe-se a situação em que uma determinada entidade associativa confere a uma determinada classe de associados o direito de votar e ser votado em assembleia geral, mas condiciona a promoção do associado a essa categoria a critérios estabelecidos exclusivamente pela diretoria e que não estão dispostos em estatuto. Em tal situação é possível dizer que os integrantes da diretoria podem eleger aqueles que terão direito a voto - e que, por conseguinte, poderiam destituí-los - e, ainda, podem manter uma classe de associados sem qualquer direito (a voz, a voto ou a participação em assembleias).

Esse tratamento claramente desigual, engendrado por norma interna arbitrariamente estabelecida pela diretoria, foi justamente o que o Código Civil procurou evitar quando textualmente estabeleceu os requisitos que devem ser atendidos pelos estatutos da associação. Como ressaltado anteriormente, as exigências do diploma legal em questão foram ampliadas a partir do ano de 2005, com a edição da Lei $\mathrm{n}^{\circ} 11.127$, em que o legislador teve como foco a moralização interna das entidades associativas, passando a prever a necessidade de ampla defesa nos procedimentos de exclusão de sócio e a manutenção de mecanismos de gestão e aprovação de $\operatorname{contas}^{522}$.

Entidades cujos estatutos contêm vícios dessa natureza - não se preocupando, pois, com a regularidade, a transparência e a seriedade da gestão de seus sócios e dos ativos sociais - não podem ser consideradas associações constituídas na forma da lei e, como tal, não têm legitimidade para propor ações coletivas. E, conquanto não se possa afirmar que esses vícios estatutários, isoladamente considerados, tenham impacto direto na atuação da entidade associativa perante terceiros, ou na forma como ela conduz determinado processo, é uma das vias das quais o juiz pode utilizar para verificar a atuação da entidade na prática e averiguar se ela efetivamente representa ou não seus associados - e, até mesmo, a coletividade como um todo.

${ }^{522}$ Cf. Capítulo 3, subitem 3.2. 
Verificando que a atuação da associação se desvia dos padrões esperados para a defesa dos interesses da coletividade, o juiz poderá esmiuçar os estatutos da entidade e verificar se ele atende a todos os requisitos formais do Código Civil - e, em não atendendo, deve negar-lhe a legitimidade por não poder ser considerada uma associação.

Esse desvio da forma associativa atinge seu ápice, no entanto, não com as disposições estatutárias narradas acima - em que se desatendem os requisitos de organização interna da associação -, e sim com o vilipêndio do que anteriormente chamouse de quid caracterizador da associação: a consecução de fins não econômicos (Artigo 53, caput do Código Civil). Isso se dá a partir do momento que se observa que uma entidade associativa age motivada pela busca do lucro, ainda que seu estatuto diga algo diferente disso, devendo, portanto, ser caracterizada como sociedade ${ }^{523}$.

O negócio jurídico e as declarações de vontade que lhe embasam, nos termos do artigo 112 do Código Civil, serão determinados pela intenção neles consubstanciadas e não pela forma que a eles se atribua. Intenção aqui não caracterizada como um elemento interior - uma vontade real, psicológica -, mas um elemento exterior - chamado pelo doutrinador português Carlos Alberto Mota Pinto de comportamento declarativo ${ }^{524}$. Em outras palavras, pouco importa que determinada entidade estabeleça em seus estatutos que é uma associação, quando, na prática, atua como se sociedade fosse, já que o negócio jurídico não é o que o agente quer que ele seja, mas sim o que a sociedade vê com a declaração de vontade do agente ${ }^{525}$.

Assim, a atuação das associações, que desviam sua finalidade - na busca de objetivos que não se coadunam com a forma associativa - só poderá ser analisada na prática, por um terceiro que sobre tais comportamentos faça um juízo de valor. No âmbito do processo, essa análise deverá ser feita pelo juiz, verificando-se a efetiva atuação da entidade e não simplesmente o texto de seus estatutos.

A busca de fins lucrativos, vedada às associações, pode ser verificada em casos em que verdadeiras sociedades de advogados se autodenominam associações - de defesa do

\footnotetext{
${ }^{523}$ Conforme amplamente descrito no capítulo 3 do presente estudo, o que afasta sociedades e associações, do ponto de vista legal, é justamente a organização dos ativos financeiros e humanos para a consecução de uma finalidade econômica. Enquanto a sociedade é justamente definida por essa busca (vide artigo 981 do Código Civil), a associação é especificamente alijada dessa possibilidade. O Código Civil de 1916 não diferenciava a contento as duas categorias, o que passou a ser feito de forma detalhada no Código de 2002.

${ }^{524}$ MOTA PINTO, Carlos Alberto. Teoria geral do direito civil. 4. ed. atualizada por Antonio Pinto Monteiro e Paulo Mota Pinto. Coimbra: Coimbra, 2005, p. 413-414.

525 JUNQUEIRA DE AZEVEDO, Antonio. Negócio Jurídico - existência, validade e eficácia. 4. ed. São Paulo: Saraiva, 2007, p.21.
} 
consumidor, do Meio Ambiente, do patrimônio público -, mas se estruturam de uma forma que toda a receita angariada com honorários advocatícios nas ações coletivas por elas propostas é distribuída internamente entre os associados e diretores. Não é raro que, nesses casos, os associados sejam pessoas cuja organização interna em nada difere de uma estrutura típica de escritório de advocacia ${ }^{526}$.

Tais entidades, ainda, aproveitam-se das benesses legais, concedidas aos litigantes que defendem os direitos transindividuais, para atingir finalidades egoísticas. Isso porque, salvo se comprovada má-fé, as associações não estão expostas aos riscos inerentes às ações judiciais comuns, já que o legislador isentou os legitimados ativos do pagamento de custas e honorários advocatícios em caso de improcedência ${ }^{527}$.

Analisando a atuação de tais entidades, percebe-se que não apenas há desvio da forma associativa, o que de pronto serviria para afastar a legitimidade ativa - já que a pessoa jurídica se define pela forma como atua e não pelo seu nomen juris e também pelo fato da sociedade não poder ingressar com ações coletivas -, como há também reflexos tangíveis na representatividade adequada. Ao agir com intuitos egoísticos, visando angariar receitas para os associados ou para os membros da diretoria por meio da propositura de ações coletivas, essas pretensas associações não estão preocupadas de forma primordial com a defesa dos interesses veiculados na demanda, tampouco em fazê-lo da forma mais séria e idônea possível. Não estão, portanto, representando adequadamente os interesses dos associados e, por vezes, da coletividade como um todo.

A aferição da representatividade adequada, nesse tocante, pode ser auxiliada por uma leitura aprofundada do artigo 87 do Código de Defesa do Consumidor. Tal artigo, em seu caput e parágrafo únicos, se ocupa de prever condenação em honorários advocatícios, custas e despesas processuais - além de possível ressarcimento de perdas, danos e multa no valor do décuplo das custas - que serão arcados solidariamente pelos integrantes da diretoria da associação quando esta age de má-fé. Entretanto, não há nenhuma disposição que considere que tais atos são característicos de entidades que não estão comprometidas

\footnotetext{
${ }^{526}$ O Ministério Público de São Paulo reconhece a estrutura de escritório de advocacia na associação ANADEC, conforme o parecer estudado no capítulo 7, subitem 7.3.

527 Art. 87. Nas ações coletivas de que trata este código não haverá adiantamento de custas, emolumentos, honorários periciais e quaisquer outras despesas, nem condenação da associação autora, salvo comprovada má-fé, em honorários de advogados, custas e despesas processuais.

Parágrafo único. Em caso de litigância de má-fé, a associação autora e os diretores responsáveis pela propositura da ação serão solidariamente condenados em honorários advocatícios e ao décuplo das custas, sem prejuízo da responsabilidade por perdas e danos.
} 
com a defesa dos interesses transindividuais de forma idônea e séria, retirando-lhes a legitimidade para agir.

A ideia circunscrita nesse artigo, no que diz respeito às associações, deveria ser lida de acordo com o artigo 50 do Código Civil, que trata das hipóteses de desconsideração da personalidade jurídica e menciona entre os casos de desconsideração aqueles em que se possa apurar "abuso da personalidade jurídica, caracterizado pelo desvio de finalidade" Em outras palavras, não há como admitir que uma entidade que age nitidamente em desvio de finalidade, de forma claramente abusiva, possa representar adequadamente os interesses da coletividade.

Em casos de litigância de má-fé, desvio da forma associativa e da finalidade da associação, deverá ser negada a legitimidade às citadas entidades, se não pelo fato de que não podem sequer ser consideradas associações, porque estão a cometer inequívoco abuso de direito processual ${ }^{529}$. Nesse caso, o abuso do direito perpetrado pelas associações no campo do direito material, ou seja, o desvio da forma associativa, adentra no processo pela via da legitimidade extraordinária conferida às associações para pleitear direitos da coletividade com as benesses que a lei a elas concede para garantir e facilitar o amplo e pleno acesso à justiça.

Como anteriormente analisado, a legitimidade ad causam é uma das condições da ação, portanto, um dos requisitos que devem estar presentes desde o momento da propositura da demanda, de modo que sua ausência implicará na extinção da ação sem a apreciação do mérito (artigo 267, VI do Código de Processo Civil). Pode ser definida como uma atribuição específica para agir concretamente, conferida exclusivamente pelo direito material aos sujeitos de direito, partes em uma relação ou situação jurídica de direito

\footnotetext{
${ }^{528}$ Artigo 50. Em caso de abuso da personalidade jurídica, caracterizado pelo desvio de finalidade, ou pela confusão patrimonial, pode o juiz decidir, a requerimento da parte, ou do Ministério Público quando lhe couber intervir no processo, que os efeitos de certas e determinadas relações de obrigações sejam estendidos aos bens particulares dos administradores ou sócios da pessoa jurídica.

${ }^{529}$ Sobre o assunto, e textualmente dizendo tratar-se de caso de desconsideração da personalidade jurídica, manifesta-se Kazuo Watanabe: “O parágrafo único do artigo 87 não teve o objetivo de limitar às associações as responsabilidades pela litigância de má-fé. Apenas procurou deixar claro que, pela desconsideração da personalidade jurídica, também os diretores responsáveis pela propositura da ação deverão ser condenados, e não apenas a associação por eles representada, e ainda cuidou de estabelecer uma penalidade específica, que é a do pagamento do décuplo das custas, além da verba advocatíciae condenação em perdas e danos" (GRINOVER, Ada Pellegrini; WATANABE, Kazuo; NERY JUNIOR, Nelson. Código Brasileiro de Defesa do Consumidor comentado pelos autores do anteprojeto...Op. cit., p.122). A desconsideração da personalidade jurídica é reconhecidamente, no ordenamento jurídico brasileiro, medida drástica e utilizada somente em casos de nítido abuso pelo que não é possível reconhecer que um litigante, a um só tempo, atue de forma tão inidônea e abusiva - a ponto de ser possível a desconsideração da personalidade jurídica - e seja um bom representante dos interesses de seus associados e/ou da coletividade. Na jurisprudência, sobre o tema, ver Recurso Especial 1233379 / SP, Min. Relator Sidnei Beneti, terceira turma, DJe 11/10/2012.
} 
material sobre as quais há uma lide, podendo também, por razões diversas, ser conferida a outros sujeitos de direito que não integraram a relação ou situação jurídica de direito material $^{530}$. Nas palavras de Barbosa Moreira "[...] a legitimidade ad causam significa que uma dada pessoa se apresenta como titular de uma relação jurídica material, tal como retratada na petição inicial" ${ }^{\text {531 }}$.

Quando se fala na legitimidade ad causam no processo individual, remanesce a definição na qual o legitimado, para estar em juízo, é o titular do direito subjetivo que ali se pretende discutir. Nos processos coletivos, no entanto, é forçoso reconhecer significativas alterações nos institutos processuais, até então regulados quase que exclusivamente pelo Código de Processo Civil ${ }^{532}$. E a mudança que aqui se pretende analisar de forma mais aprofundada é a ampliação dos critérios de atribuição de legitimidade para a propositura de ações, mais especificamente para a propositura de ações coletivas $^{533}$. Na lição do professor Cândido Rangel Dinamarco, a legislação brasileira acompanhou a tendência generalizada à ampliação da legitimidade ad causam ativa, de modo que com mais agilidade o Poder Judiciário pudesse positivar soluções mediante uma só atividade e envolvendo toda uma comunidade de pessoas ligadas por interesses comuns $^{534}$, passando a legitimar entidades, como as associações, para que estas pudessem pleitear os direitos da coletividade.

A situação legitimante que serve de fundamento ao agir da associação civil, nas ações coletivas, é a defesa em juízo dos direitos afeitos às suas finalidades institucionais ${ }^{535}$, defesa essa que deve ser realizada da melhor forma possível, alocando os melhores esforços da entidade em juízo, com a seriedade necessária à relevância dessa atuação em benefício da coletividade. Por esse motivo, o legislador optou por estabelecer requisitos

\footnotetext{
${ }^{530}$ FREIRE, Rodrigo da Cunha Lima. Condições da Ação, enfoque sobre o interesse de agir no processo civil brasileiro. São Paulo: Ed. RT, 2000, p. 74.

${ }^{531}$ BARBOSA MOREIRA, José Carlos. Apontamentos para um estudo sistemático da legitimação extraordinária. Revista dos Tribunais. São Paulo: RT, nº 404, 1969, p. 10.

${ }^{532} \mathrm{Cf}$. Capítulo 4 deste estudo, subitem 4.2.

${ }^{533}$ Observou-se uma necessidade de se superar ou adequar os institutos processuais tradicionais, para que pudessem ser aplicados aos processos coletivos. Conforme observado pelo eminente doutrinador Mauro Capelletti, entre os institutos que deveriam demandar maior atenção, nesse particular, estariam a legitimação, o interesse de agir, os limites da coisa julgada, entre outros. Ver CAPELLETTI, Mauro. Formações Sociais e Interesses Coletivos diante da Justiça Civil. Revista de Processo, São Paulo: RT, ano II, n ${ }^{\circ}$, p. 128-159, 1977.

${ }^{534}$ DINAMARCO, Cândido Rangel. A instrumentalidade do processo. 6. ed. São Paulo: Malheiros, 1998, p. 218.

${ }_{535}$ ROCHA, Luciano Velasque. Ações Coletivas. Rio de Janeiro: Forense, 2007, p. 158.
} 
objetivos para a atribuição da legitimidade às associações civis ${ }^{536}$, no entanto, do que até aqui se relatou, nota-se que tais requisitos não têm sido suficientes para garantir a seriedade das demandas propostas pelas associações, em outras palavras, não são suficientes para coibir o abuso do direito de demandar perpetrado por algumas entidades.

Os requisitos para a atribuição da legitimidade devem ser preenchidos no campo do direito material, ou seja, a entidade, para ingressar com ações coletivas em defesa de direitos alheios, deve: (i) ser materialmente uma associação; (ii) estar constituída há mais de um ano nos termos da legislação civil; e (iii) ter em seu estatuto a menção às finalidades institucionais que pretende defender judicialmente ou extrajudicialmente. Ainda que a ideia da legitimidade extraordinária se dissocie do conceito da titularidade do direito subjetivo afirmado no processo, não se pode dizer que seja uma construção meramente processual, independente do direito material ${ }^{537}$.

O exercício inadmissível (abusivo) de posições jurídicas se dá com relação à utilização da forma de associação. Se, como dito, as associações são caracterizadas por não poderem desenvolver atividade com finalidade econômica ${ }^{538}$, a constituição ou utilização de associações para finalidades econômicas, como a propositura de ações civis públicas com o fito de obter honorários advocatícios para seus membros, constitui evidente exercício inadmissível de direito.

Dessa forma, se algum tipo de abuso de direito é praticado por alguma entidade com o objetivo de preencher algum dos requisitos estabelecidos pela lei para a atribuição de legitimidade ativa - neste caso, configurando a caracterização como associação -, tal abuso de direito material implicará, também, em um abuso de direito no âmbito do processo.

Em casos como esses, o preenchimento dos requisitos para a caracterização do abuso de direito ocorre da seguinte maneira: a titularidade de um direito e a aparência de legalidade do ato praticado correspondem ao direito de livre associação e ao registro de estatutos aparentemente na forma da lei, respectivamente. Já no que toca ao direito processual, o direito exercido é o direito de demandar (preconizado pelo artigo $5^{\circ}, \mathrm{XXXV}$

\footnotetext{
${ }^{536}$ Nesse sentido, ver Rodolfo de Camargo Mancuso: “É compreensível o propósito do legislador: evitar que associações não suficientemente sólidas, ou cujos objetivos não se coadunem com o interesse difuso em causa, proponham, sem maior ponderação, ação coletiva [...]”. (MANCUSO, Rodolfo de Camargo. Ação Civil Pública, em defesa do meio ambiente, do patrimônio cultural e dos consumidores. São Paulo: Ed. RT, 2004, p. 184.

${ }^{537}$ Nesse sentido, ver BEDAQUE, José Roberto dos Santos. Direito e Processo, a influência do direito material sobre o processo. 5. ed. São Paulo: Malheiros, 2009, p. 107-108.

${ }^{538}$ LEONARDO, Rodrigo Xavier. As associações em sentido estrito....Op. cit., 105-116.
} 
da Constituição Federal) e a aparência de legalidade é determinada pela atribuição de legitimidade às associações que preencherem, ou aparentemente preencherem, os requisitos já mencionados.

Assim, ainda que o simples reconhecimento da ilegitimidade ativa não implique, necessariamente, o reconhecimento de abuso de direito de demandar, é certo que, em alguns casos - marcados principalmente pelo desvio de finalidade perpetrado por algumas associações -, o abuso estará, sim, presente. Como bem pontua Helena Najjar Abdo, é inadmissível que o complexo de situações jurídicas processuais que é a ação seja utilizado de modo distorcido ou em desarmonia com as suas finalidades intrínsecas.

E, conforme ressaltado, não é possível admitir que uma entidade que exercita de forma abusiva o direito de ação - via reflexa do abuso da forma associativa - possa ser considerada uma boa representante dos direitos dos seus associados e, menos ainda, de toda a coletividade. Ao afastar o abuso de direito nesses casos, o juiz estará também aferindo a representatividade adequada do litigante, evitando que entidades carentes de seriedade e idoneidade - características do representante adequado em todos os ordenamentos jurídicos em que o conceito é amplamente aceito ${ }^{539}$ - conduzam ações coletivas.

Ademais, o abuso de direito processual das associações pode estar circunscrito, ainda, em outro requisito exigido pela lei para a atribuição da legitimidade ativa a tais entidades: a inclusão entre suas finalidades estatutárias da defesa dos interesses tutelados em determinada ação coletiva, como adiante se verá. Assim, a verificação detalhada dos estatutos dessas associações e a forma como, na prática, desenvolvem as finalidades que se propõem a defender caracterizam-se como outra via de controle da representatividade adequada que pode ser utilizada pelos juízes no caso concreto.

\subsubsection{As finalidades estatutárias como forma de controle da representatividade adequada: a excessiva amplitude dos objetivos institucionais e o abuso do direito de demandar}

Nos capítulos anteriores ressaltou-se que entre os requisitos para a atribuição de legitimidade às associações, além da pré-constituição há pelo menos um ano e ser efetivamente uma entidade associativa constituída nos termos da lei, está a inclusão, entre

$\overline{{ }^{539} \text { Cf. Capítulo 5, subitens } 5.2 \text { e 5.3. }}$ 
as finalidades estatutárias da associação, dos direitos que pretendem defender em juízo. Disso decorre que se uma entidade pretende ingressar com ações na defesa dos direitos dos consumidores, deverá mencionar essa intenção entre seus objetivos institucionais. Aliás, a eleição de determinados fins institucionais não apenas é requisito para a atribuição da legitimidade ativa extraordinária como, também, é parte indispensável do estatuto da associação, sob pena de nulidade ${ }^{540}$ que, nesse caso, implica a ineficácia do negócio jurídico associativo.

A exigência legal de que o perfil institucional do legitimado ativo para a propositura das ações coletivas se identifique com os direitos por ele pleiteados em juízo também se coaduna com a ideia de legitimação. Se na legitimidade extraordinária não há identidade entre o titular do direito material violado e aquele que o defenderá em juízo, é preciso que, de alguma forma, apure-se o liame entre o direito pleiteado e o autor da ação. Esse vínculo é o que garantirá que o autor da ação tem algum grau de intimidade com os direitos veiculados na ação coletiva e, com isso, poderá fazer uma defesa de qualidade dos interesses em pauta ${ }^{541}$.

Por ter esse escopo, de buscar a consecução de uma defesa de qualidade - por selecionar para o polo ativo entidades que respeitem o que se convencionou chamar de pertinência temática com o objeto da ação -, o requisito da inclusão dos direitos defendidos em juízo entre as finalidades institucionais é descrito por alguns doutrinadores como a única possibilidade de aferição da representatividade adequada descrita no ordenamento jurídico do Brasil ${ }^{542}$ - opinião com a qual não se concorda, pelo que já se expôs.

Sozinho, no entanto, o dispositivo legal que aborda a pertinência temática não tem o condão de coibir condutas desidiosas, abusivas ou inadequadas - em suma, carentes de representatividade adequada - por parte das associações. Isso porque o artigo que rege a

\footnotetext{
${ }^{540}$ Art. 54. Sob pena de nulidade, o estatuto das associações conterá: I - a denominação, os fins e a sede da associação.

${ }^{541}$ O professor Cândido Rangel Dinamarco assinala que o vínculo pessoal com o direito defendido em juízo é o que, de forma mais eficiente, vai garantir a melhor defesa desses interesses. (DINAMARCO, Cândido Rangel. Instituições de Direito Processual Civil. 5.ed. São Paulo: Malheiros, 2005, p. 235). Se esse vínculo é impossível no que tange aos processos coletivos, já que os efetivos sujeitos passivos do dano (indivíduos) não são legitimados para a defesa dos direitos de toda a coletividade, é a inclusão de determinados temas entre os fins institucionais que garantirá, em alguma medida, a qualidade da defesa e, com isso, a legitimidade do litigante.

${ }_{542}$ Conforme tratado no capítulo 4 deste estudo, filia-se a essa corrente de Álvaro Luiz Valery Mirra (“Ação Civil Pública em defesa do meio ambiente: a representatividade adequada dos entes intermediários legitimados para a causa" (MIRRA, Álvaro Valery. In: MILARÉ, Édis (coord.). A ação Civil Pública após 20 anos: efetividade e desafios. São Paulo: RT, 2005, p. 33-57)
} 
pertinência temática se limita a exigir a inclusão no estatuto da finalidade institucional, de modo que se determinada associação previsse em seu estatuto o escopo de defesa do Meio Ambiente e ingressasse com ação acerca do tema, ela estaria legitimada - de acordo com uma apuração feita pelo juiz de forma objetiva em um primeiro contato com a ação. $\mathrm{O}$ dispositivo não prevê, ao menos textualmente, a possibilidade do juiz requerer maiores esclarecimentos com relação à aptidão da entidade na defesa do Meio Ambiente e tampouco se presetaria a embasar a revogavação da legitimidade ativa caso a atuação da associação não o fizesse a contento.

Por esse motivo, reitera-se que esse requisito legal é, apenas e tão somente, um fator para a atribuição de legitimidade ativa ${ }^{543}$, que traduziu de alguma forma a preocupação do legislador com a boa representação dos interesses coletivos, não podendo - justamente por isso - limitar a aferição da representatividade adequada pelo juiz. Pode, por outro lado, ajudar a promover essa verificação.

Isso porque se a lei prescreve que determinada associação somente poderá defender em juízo temas afeitos aos seus objetivos institucionais, que guardem pertinência temática com as atividades desenvolvidas pela entidade, para garantir que a defesa seja feita com um mínimo de qualidade e conhecimento, o juiz deverá não apenas analisar a letra do estatuto para verificar a legitimidade, como também apurar a atuação da entidade no curso do processo. Sair, pois, da análise textual, para na apuração da atuação da associação perfazer o sentido da lei, que é o de garantir que os direitos transindividuais sejam tutelados adequadamente.

Ainda sem concordar com todas as premissas fixadas por Ricardo Barros Leonel sobre o tema, ressalta-se a lição do autor ao diferenciar a verificação da pertinência temática e a aferição da atuação da associação e, por conseguinte, de sua representatividade adequada:

\footnotetext{
Em síntese, a verificação da denominada "pertinência temática" que se resolve na adequação entre o perfil institucional do legitimado e o objeto do litígio coletivo, está centrada na aferição da legitimidade e/ou interesse de agir a partir da hipótese concretamente considerada.

Outro problema, no entanto, diz respeito à verificação da aptidão técnica da associação para a defesa do interesse coletivo. Embora a adequada representação tenha sido estabelecida por critério legal (existência da entidade há pelo menos um ano e inserção, em seus estatutos, da finalidade de defesa de determinados interesses) não se pode descartar a possibilidade de controle judicial sobre a efetividade dessa adequação.
}

${ }^{543}$ Cf. capítulo 4, Subitem 4.4.2. 
Em outras palavras a lei cria uma presunção de adequação de representação quanto às associações. Mas essa presunção não é absoluta, e pode ser afastada no caso concreto. Se isso ocorrer (o juiz constata que a associação não tem, em realidade, aptidão técnica para bem representar a coletividade), será cabível a extinção do feito sem exame do mérito, por falta de legitimação decorrente da inadequação concreta da representação ${ }^{544}$.

Até porque as finalidades estatutárias das entidades associativas não têm um fim em si mesmas, elas se prestam a listar aquilo que a associação reunirá esforços e recursos técnicos, financeiros e humanos - para defender na prática o interesse da coletividade. Com isso, retoma-se o raciocínio desenvolvido no tópico anterior: se o negócio jurídico deve ser interpretado por "aquilo que a sociedade vê como a declaração de vontade do agente", a efetiva concretização das finalidades estatutárias só poderá ser aferida por meio da atuação da associação.

A representatividade adequada das associações, portanto, também estará atrelada à forma como elas se comportam no desenvolvimento das atividades sociais para atingir as finalidades institucionais a que se propuseram. E isso, diga-se, inclui a atuação judicial e extrajudicial na tutela dos interesses que as associações se propuseram a defender ${ }^{545}$. O juiz, portanto, não pode e nem deve ficar atrelado somente ao texto do estatuto, devendo analisar também a atuação das associações no dia a dia, já que é só cumprindo efetivamente o papel a que se propuseram que tais entidades se especializarão o suficiente para promover uma defesa adequada dos direitos transindividuais.

O texto do estatuto pode comportar uma série de minúcias que somente poderão ser analisadas por meio de uma investigação mais aprofundada, aliada à verificação da atuação da associação na vida diária. Veja-se, como exemplo dessa premissa, o caso da ACEDESFE (Associação Cearense de Defesa da Saúde dos Fumantes e ex-Fumantes). Como o próprio nome esclarece, a associação foi constituída para viabilizar a defesa de fumantes e ex-fumantes, tendo feito constar de seus estatutos o seguinte:

Art. 01 - A Associação Cearense de Defesa da Saúde do Fumante e Ex-Fumante - ACEDESFE, entidade civil sem fins lucrativos, com sede e foro na cidade de Fortaleza - Ceará (...), representando os fumantes, ex-fumantes, contribuintes e

\footnotetext{
${ }^{544}$ LEONEL, Ricardo de Barros. Manual do Processo Coletivo. 2. Ed. São Paulo: Saraiva, 2011, p. 173.

545 Observe-se, nesse sentido, o caso do Instituto Brasileiro de Defesa do Consumidor (IDEC), uma das mais prestigiosas associações de defesa do consumidor no Brasil. Ela não apenas propõe ações que pretendem tutelar os direitos do consumidor, mas busca atingir sua finalidade estatutária - notadamente a defesa do consumidor - por meio também da orientação extrajudicial, com a promoção de eventos, que procuram instruir os consumidores sobre temas correntes e esclarecer dúvidas acerca de direitos que essa classe de pessoas possa vir a ter (http://www.idec.org.br/mobilize-se/eventos. Consultado em 12set.2012).
} 
consumidores independente das convicções político-partidárias e religiosas bem como todos os demais consumidores.

Uma leitura superficial do artigo supracitado, o primeiro do estatuto da referida associação, permite identificar que o objeto primário da associação é a representação e defesa dos direitos dos fumantes e ex-fumantes e que tal objeto foi ampliado de forma indevida, para tentar incluir entre as finalidades estatutárias da entidade a defesa dos direitos do consumidor em geral. Entretanto, o artigo $2^{\circ}$ deste mesmo estatuto dá melhores explicações sobre o objeto da Associação: até a alínea "t" do referido artigo - que contempla todo o alfabeto - são descritas como finalidades da ACEDESFE toda sorte de defesa dos interesses dos "consumidores, ex-fumantes, contribuintes, familiares de consumidores falecidos e associado"”.

Ao ficar apenas na superfície do texto acima, o magistrado poderia acabar por atribuir a essa associação a legitimidade ativa para a defesa dos interesses, por exemplo, de correntistas de uma instituição financeira em uma ação que versasse sobre contratos bancários - consumidores que são. Uma leitura mais atenta, no entanto, leva a perceber que, o tempo todo, a palavra "consumidor" é utilizada como sinônimo de "fumante" (consumidor de cigarros). Mais do que isso, uma análise da atuação da associação em questão levaria à conclusão de que a entidade tem sim legitimidade para representar a coletividade no que tange às questões relacionadas ao consumo de tabaco e congêneres ${ }^{546}$, mas é ilegítima para defender interesses de correntistas de instituições financeiras referentes a contratos bancários ${ }^{547}$.

No caso exposto, a associação carece de representatividade adequada para defender os interesses dos titulares de caderneta de poupança, já que a razão da aglutinação de pessoas - e o objetivo da associação, na prática - é a defesa dos direitos dos consumidores de tabaco e questões relacionadas ao consumo dessas substâncias. Sobre o tema, pondera Teori Albino Zavascki:

\footnotetext{
546 A associação ACEDESFE propôs, durante o ano de 2004, demandas coletivas pleiteando indenizações para os fumantes e seus familiares, em caso de doenças crônicas por eles desenvolvidas ou mesmo morte eventualmente ocasionada pelo tabaco. Nesses casos, conquanto as ações tenham sido extintas sem julgamento do mérito, dada a impossibilidade de tratamento coletivo da questão (especificidades que tornam despicienda a ação coletiva), não se discorda que a ação esteja dentro dos propósitos estatutários da entidade. (informação disponível em http://www.conjur.com.br/2004-out-08/associacao_fumantes_exfumantes_nao_propor_acao. Consultado em 15set.2012).

${ }^{547}$ A associação em questão ingressou, no ano de 2007, com processo $\left(n^{\circ} 2007.0013 .4430-5\right)$ perante a $21^{\mathrm{a}}$ Vara Cível de Fortaleza, com ação coletiva, contra 15 instituições financeiras, pretendendo o pagamento a todos os poupadores do estado do Ceará dos expurgos inflacionários dos planos econômicos Bresser e Verão.
} 
Um outro limite é imposto pelo interesse de agir da instituição legitimada: sua atuação deve guardar relação com seus fins institucionais. Às associações culturais cabe tutelar direitos de seus filiados relacionados à cultura (e não a outros, estranhos ao âmbito associativo); às associações esportivas e recreativas, os interesses relacionados com esporte e recreação; às associações de defesa do consumidor, os direitos decorrentes de relações de consumo; às entidades profissionais, os direitos de seus filiados ligados ao exercício de uma profissão. Quem se filia a associação destinada a pesca submarina não o faz imaginando que a entidade vá tutelar seus direitos relacionados à questões fiscais, ou suas relações condominiais ou de vizinhança ${ }^{548}$.

Raciocínio análogo se aplica às situações em que as associações arrolam entre seus objetivos institucionais uma gama tão ampla de direitos que não é possível aferir em qual área a entidade tem expertise e, por conseguinte, condições de prover uma tutela adequada $^{549}$.

Sendo assim, parece certo afirmar que uma determinada associação deve se dedicar a um número determinado de matérias, justamente para que possa atuar com diligência e conhecimento na defesa - judicial e extrajudicial - dos direitos afeitos a tais temas. Essa delimitação é, também, uma garantia para os associados, que têm o direito de saber quais direitos seus serão tutelados pela entidade a qual se associou. Assim, hoje, tem-se uma gama variada de associações, como associações de defesa do consumidor, associações de defesa ao meio ambiente, associações de mutuários, entre outras.

Por vezes, entretanto, surgem associações que abarcam sob suas finalidades institucionais a defesa de tantos e tão diversificados direitos, que é possível entrever a inviabilidade da entidade para se especializar em todos eles e, consequentemente, a inviabilidade da defesa de algum deles em juízo com o mínimo de qualidade e seriedade. Em outras palavras, aquele que pretende defender em juízo todos os direitos, em regra não defenderá - com o esmero necessário - nenhum deles. Por isso, é preciso verificar, caso a caso, qual o real objetivo da associação, ou seja, o motivo primordial pelo qual as pessoas se uniram naquele grupo.

Além disso, os objetivos institucionais de determinada associação devem fazer referência ao vínculo imprescindível entre sua atuação e os interesses de seus associados vale dizer, a relação de pertinência exigida entre o objeto da ação e o objeto da associação

\footnotetext{
${ }^{548}$ ZAVASCKI, Teori Albino. Processo Coletivo. São Paulo: Editora RT, 2006, p. 176.

${ }^{549}$ A mens legis do é um dispositivo que tem fundamento na ideia de que a associação deve ser, de alguma forma, especializada em algum campo de atuação - o que possibilitaria uma defesa qualificada dos interesses de seus associados e, em alguns casos, de todos os integrantes de determinada coletividade. Nesse sentido, ver COSTA, Susana Henriques da. Comentários à Lei de Ação Civil Pública e Lei de Ação Popular. São Paulo: Ed. Quartier Latin, 2006, p. 406-407.
} 
privada que a move não se desconecta da relação entre este objeto da entidade e o interesse de seus membros.

Nesses casos, é possível dizer, desde logo, que o requisito legal concernente à atenção às finalidades institucionais não foi preenchido, o que deverá acarretar na extinção da ação sem o julgamento do mérito, dada a ilegitimidade das associações.

Como narrado, a exigência legal da pertinência temática tem como finalidade garantir a qualificação da defesa dos direitos difusos, coletivos e individuais homogêneos em juízo, permitindo que entidades efetivamente atuantes - inclusive extrajudicialmente na defesa desses temas promovam uma defesa judicial de qualidade do interesse dos indivíduos ali representados ou substituídos.

Ademais, os objetivos institucionais se prestam a informar aos associados ou potenciais associados que interesses são defendidos por aquela entidade. Uma gama de finalidades amplíssima e dissonante pode, também, dar azo a conflitos de interesses internos. Imagine-se que empresários do ramo da construção civil, fumantes, associem-se à entidade que se presta a defender os direitos dos consumidores de tabaco, como a do exemplo acima (ACEDESFE), e tal entidade, por colocar entre seus objetivos institucionais a defesa dos consumidores - genericamente considerados - ingressa com ação coletiva embargando obras das empresas controladas por tais empresários. Nesse caso, é certo que a associação estará agindo em conflito de interesses com pelo menos parte de seus associados.

Ao incluir entre suas finalidades institucionais os mais diversos e dissonantes direitos - que muitas vezes sequer fazem parte de sua agenda de atuação -, as associações podem ter como objetivo a propositura de demandas coletivas sobre os mais diversos assuntos sem, no entanto, garantir uma defesa de qualidade dos direitos que se propuseram a resguardar. Uma desmesurada amplitude de finalidades institucionais impacta, portanto, na representatividade adequada, já que não é crível que uma associação tenha qualificação técnica e mesmo financeira para, por exemplo, defender todos os direitos listados nos $\operatorname{artigos} 5^{\circ}$ e $6^{\circ}$ da Constituição Federal ${ }^{550}$.

\footnotetext{
${ }^{550}$ Cite-se, como exemplo o estatuto da Associação Catarinense de Defesa dos Cidadãos, dos Consumidores e dos Contribuintes, que declina como seus objetivos institucionais: "A Associação Catarinense de Defesa dos Cidadãos, dos Consumidores e dos Contribuintes - ACC/SC, ora denominada ACC, tem por finalidade e objetivo congregar todos os seus Associados a fim de promover o desenvolvimento deste País, podendo, ainda, promover a defesa das garantias constitucionais, dos direitos humanos, do direito à liberdade, à justiça e à igualdade, da dignidade da pessoa humana, da cidadania, da saúde, da ordem social, da assistência social, da família, da cultura, da ciência, do meio ambiente, da preservação de recursos naturais tais como as florestas, a fauna, a flora, a água, o ar, o solo e subsolo, do patrimônio público, dos bens e direitos de valor
} 
Com base nessa excessiva amplitude de objetivos da associação, o juiz poderá realizar a aferição da representatividade adequada, seja através da avaliação do comportamento da associação no curso do processo - analisando se, para além da declaração em estatuto, ela efetivamente tem aptidão para a defesa dos interesses em questão -, seja eventualmente pedindo para que a própria associação comprove sua efetiva atuação da defesa dos direitos veiculados naquela ação coletiva. Isso implica, como já dito, sair da superfície do texto legal para interpretar a norma de acordo com seu objetivo dentro do microssistema dos processos coletivos.

O controle judicial da representatividade afigura-se, nesse cenário, indispensável, porque o ato de descrever entre suas finalidades institucionais um número impraticável de objetivos implica desvio de finalidade, que caracteriza, também nesse caso, o abuso de direito. Isso porque as associações que não têm qualquer experiência ou expertise em determinados ramos do direito, justamente porque não atuam efetivamente em sua defesa, incluem-nos em seus estatutos com o objetivo de propor o maior número de demandas coletivas possível, podendo, consequentemente, aumentar a arrecadação de receita por meio da captação de honorários - mais uma vez sem correr o risco de incorrer em sucumbência.

artístico, estético, histórico, turístico e paisagístico, da segurança, do bem-estar, do desporto, da educação, do devido processo legal e da ordem jurídica, da livre concorrência, do sistema tributário nacional, dos direitos políticos, da função social da propriedade, do efetivo exercício dos direitos sociais e individuais, dos valores sociais do trabalho e da livre iniciativa, dos cidadãos, dos direitos fundamentais das crianças e dos adolescentes, dos idosos, dos consumidores e dos contribuintes, sejam pessoas físicas ou jurídicas, dos pensionistas, dos estudantes de forma geral e dos universitários, quês pertençam à aera pública ou privada, dos servidores públicos, dos poupadores, dos deficientes físicos, sensoriais, psíquicos e mentais, dos dependentes químicos, dos trabalhadores, qualquer que seja a forma de contratação ou categoria profissional, dos adquirentes de unidades autônomas destinadas a fins residenciais ou não-residenciais e de loteamento ou desmembramento de solo urbano ou rural, dos aposentados, dos usuários de serviços públicos ou qualquer outra forma de denominação que tenha suas relações com o meio social e ainda perante o poder econômico ou Poderes Estatais, dos mutuários do sistema financeiro de habitação e outros similares, dos investidores do mercado de capitais, dos presos, qualquer que seja sua forma, as causa da pobreza e os fatores de marginalização, podendo promover integração social dos setores desfavorecidos, a infração de ordem econômica e à economia popular, o abuso de poder econômico que vise à dominação de mercados, à eliminação de concorrência e o aumento arbitrário dos lucros, as incorporações imobiliárias irregulares que prejudiquem de qualquer forma a coletividade bem assim o parcelamento do solo urbano irregular em qualquer de suas formas, improbidade administrativa, podendo, ainda, defender através de todos os remédios constitucionais, medidas legais, judiciais, extrajudiciais e administrativas QUAISQUER OUTROS INTERESSES OU DIRETOS DIFUSOS, COLETIVOS E/OU INDIVIDUAIS HOMOGÊNEOS, independentemente de autorização assemblear.

$\S$ único - A descrição procedida no caput deste artigo não possui caráter taxativo, mas, tão somente, exemplificativo". 
Assim, seja pela interpretação sistêmica dos dispositivos da Constituição Federal, do Código Civil e do Código de Defesa do Consumidor, preconizando a aferição da qualidade de associação da entidade que ingressa com a ação coletiva, seja pela verificação da efetiva atenção às finalidades institucionais na atuação das associações que pretendem tutelar os direitos transindividuais, os juízes têm condições para sair da análise superficial do texto dos estatutos das entidades associativas que figuram no polo ativo de processos coletivos. Fazendo isso, será possível verificar se tais entidades efetivamente defendem os interesses de seus associados, e, por vezes, de toda a coletividade, e se atuam de acordo com os valores fundamentais do ordenamento jurídico pátrio - entre eles a boa-fé -, uma vez que só nessa situação poderá ser considerada integralmente atendida a garantia constitucional do devido processo legal.

Passa-se, pois, à análise da jurisprudência pátria, com o fito de verificar se os juízes, independentemente da previsão legal acerca da possibilidade e dos parâmetros de controle da representatividade adequada das associações, têm realizado essa aferição e de que forma esse escrutínio tem sido feito. Verificar-se-á, ainda, a atuação do Ministério Público, na qualidade de custus legis, na investigação das práticas inidôneas das associações e na veiculação de tais informações no processo. 


\section{A POSIÇÃO DOS TRIBUNAIS BRASILEIROS QUANTO À AFERIÇÃO DA REPRESENTATIVIDADE ADEQUADA DAS ASSOCIAÇÕES}

Neste capítulo será realizada uma análise da jurisprudência pátria no tocante à aplicação do conceito de representatividade adequada - ainda que de forma implícita - na verificação da legitimidade ativa das associações civis enquanto autoras de ações coletivas. Pretende-se entender quais são os parâmetros que juízes e tribunais têm utilizado - além daqueles listados no artigo 82, inciso IV, do Código de Defesa do Consumidor - para conferir legitimidade ativa às associações em ações coletivas.

O termo "representatividade adequada" foi a principal expressão utilizada como chave de pesquisa para buscar acórdãos nos sites de alguns Tribunais brasileiros ${ }^{551}$. Buscaram-se, ainda, os termos "associação" e "legitimidade ativa", com o objetivo de filtrar decisões que tratassem sobre a atribuição ou negativa de legitimidade às associações $^{552}$. Isso porque nem todos os julgados se referem explicitamente ao termo representatividade adequada, conquanto, em última análise, estejam aferindo a atuação da associação nesse sentido.

A seleção de julgados foi realizada de forma qualitativa, buscando trazer a estudo apenas casos específicos de julgados que utilizaram alguns critérios para aferir a representatividade adequada das associações civis - particularmente aqueles que veiculam a possibilidade de negar a legitimidade ativa às associações que atuam de forma abusiva na propositura de ações coletivas. Em outras palavras, uma vez que não se intentou projetar os resultados da pesquisa para a população ou identificar percentuais de decisões em determinado sentido, a amostra foi selecionada de modo a verificar se os conceitos trabalhados na parte teórica do estudo encontram algum eco na jurisprudência atual. Aqui,

\footnotetext{
${ }^{551}$ A pesquisa buscou decisões no Superior Tribunal de Justiça e nos seguintes tribunais estaduais: Tribunal de Justiça do Distrito Federal, Tribunal de Justiça do Espírito Santo, Tribunal de Justiça de Minas Gerais, Tribunal de Justiça do Mato Grosso do Sul, Tribunal de Justiça do Mato Grosso, Tribunal de Justiça do Pará, Tribunal de Justiça do Rio de Janeiro, Tribunal de Justiça do Rio Grande do Sul, Tribunal de Justiça de Santa Catarina, Tribunal de Justiça do Recife, Tribunal de Justiça da Bahia e Tribunal de Justiça de São Paulo. Também foram pesquisados os Tribunais Regionais Federais da Terceira Região e da Quinta Região. A intenção foi selecionar decisões sobre o tema prolatadas em todo o país e verificar se existem diferenças nas orientações de acordo com a região que se analisa.

${ }^{552}$ Nos mecanismos de busca dos sites que permitiam a veiculação das expressões entre aspas, para busca do termo exato, a pesquisa foi realizada nesses termos. Nos mecanismos de buscas que só permitiam a veiculação das palavras que compõem a expressão, a pesquisa foi feita da seguinte forma: representatividade e adequada.
} 
especificamente, será feita a interpretação de algumas decisões de tribunais que realizam o controle da representatividade adequada das associações independentemente de previsão legal expressa permitindo tal conduta ${ }^{553}$.

Além da análise de acórdãos prolatados pelos tribunais pátrios, este capítulo se propõe também a verificar a atuação do Ministério Público enquanto fiscal da lei nas ações civis públicas. A partir do estudo de um caso concreto, procurar-se-á investigar se este órgão ministerial pode manifestar-se a respeito da representatividade adequada de uma associação civil, quando esta for autora de ação civil pública, alertando o juiz da causa com relação à condutas que considerar atentatórias ao citado conceito, além de averiguar de que forma isso será feito no caso concreto.

\subsection{APURAÇÃO DA LEGITIMIDADE ATIVA DAS ASSOCIAÇÕES POR MEIO DA APLICAÇÃO DOS CRITÉRIOS LEGAIS: ANÁLISE DA JURISPRUDÊNCIA DOMINANTE NOS TRIBUNAIS PÁTRIOS}

Na pesquisa realizada através das bases digitais dos Tribunais de Justiça e Tribunais Regionais Federais brasileiros, identificaram-se aproximadamente 157 acórdãos que fazem menção ao termo "representatividade adequada" no corpo do seu texto, seguindo os critérios explanados acima. Analisando tais acórdãos, foi possível notar que grande parte dos tribunais pátrios ainda considera que a representatividade adequada das associações está aliada aos critérios legais impostos para a atribuição de legitimidade ativa expressamente listados no art.82, IV, $\$ 1^{\circ}$ do Código de Defesa do Consumidor notadamente a pré-constituição há um ano e a pertinência temática.

Conforme exposto anteriormente, este estudo não se filia à ideia de que a análise do juiz no que toca à representatividade adequada estaria limitada à verificação desses dois

\footnotetext{
553 As pesquisas qualitativas têm como objetivo primordial a análise de casos específicos, permitindo ao pesquisador desenvolver conceitos, bem como interpretar padrões encontrados nos dados, de acordo com a proposta do estudo. Trata-se de uma técnica indutiva, na qual não existe a preocupação em selecionar uma amostra representativa, com um número de decisões capaz de traduzir uma tendência que possa ser aplicada a toda a população de acórdãos. Em contraponto, existem as pesquisas quantitativas, cujo objetivo é analisar uma amostra que permita projetar os resultados para toda a população - casos em que existe uma preocupação com a delimitação da amostra, com o cálculo do universo a ser analisado para que possa ser considerado representativo do todo. O presente estudo trabalha, pois, com a primeira hipótese. Sobre metodologia de pesquisa empírica, ver: MARCONI, Marina de Andrade; LAKATOS, Eva Maria. Técnicas de pesquisa: planejamento e execução de pesquisas, amostragens e técnicas de pesquisa, elaboração, análise e interpretação de dados. 4. ed. rev. e ampl. São Paulo: Atlas, 1999 e MCCONVILLE, Mike; CHUI, Wing Hong. Research Methods for Law. Edimburg: Edimburg University Press, 2007.
} 
requisitos estabelecidos em lei ${ }^{554}$. No entanto, é preciso anotar que a maior parte da jurisprudência ainda se detém na análise de tais requisitos para atribuir ou negar legitimidade às associações, pautando-se na simples leitura dos estatutos para tanto. Exemplos dessa orientação predominante estão expressos em vários acórdãos de diversos tribunais pátrios, em que os julgadores se limitam a afirmar que determinada entidade associativa é legítima por estar constituída há mais de um ano e por declinar no estatuto que suas finalidades institucionais compreendem o direito que pretende defender em juízo 555 e 556 .

Em outras palavras, a parcela mais expressiva da jurisprudência examinada não sai da superfície da análise dos critérios legais para atribuir ou não a legitimidade ativa às entidades associativas, bastando que elas estejam, nos termos do artigo $82, \mathrm{IV}, \S 1^{\circ}$ do Código de Defesa do Consumidor, constituídas há mais de um ano e arrolem, no estatuto,entre suas finalidades institucionais a defesa dos interesses pleiteados em juízo. Esse controle, conquanto se prenda ao texto da lei, tem se mostrado eficaz no controle da representatividade adequada das associações, ao menos nos casos mais gritantes de atuação fora dos parâmetros estabelecidos pelo próprio estatuto.

\footnotetext{
${ }^{554}$ Posição defendida por Álvaro Luiz Valery Mirra em seu artigo "Ação Civil Pública em defesa do meio ambiente: a representatividade adequada dos entes intermediários legitimados para a causa" (MIRRA, Álvaro Luiz Valery. Édis Milaré (coord.). A ação Civil Pública após 20 anos: efetividade e desafios. São Paulo: RT, 2005, p. 33-57).

${ }^{555}$ A exemplo dos seguintes julgados do Tribunal de Justiça de São Paulo, especificamente o segundo deles, em que foi reformada a sentença que declarou a ilegitimidade da associação autora: "AÇÃO CIVIL PÚBLICA - Propositura por associação para a defesa de direitos estranhos às suas finalidades institucionais - Ilegitimidade ativa - Critério objetivo de aferição para a legitimidade ativa para ação civil pública previsto no artigo $5^{\circ}$, II da Lei $n^{\circ} 7.347 / 1985$ - Sentença mantida - Recurso improvido." (Apelação no 938.889-5-9, $9^{\text {a }}$ Câmara de Direito Público do Tribunal de Justiça de São Paulo, Desembargador. Relator. Rebouças de Carvalho, Julg. 10.03.2010). e "A r. sentença de Primeiro grau, contudo, extinguiu o feito sob o entendimento de que a autora é parte ilegítima para promover a presente ação. Em que pese a convicção judicial atacada por apelo, é possível entender que a recorrente tem legitimidade para ajuizar esta ação, como se infere do art. $5^{\circ}$, inciso I, da LACP, por ser associação "constituída há, pelo menos, um ano, nos termos da lei civil"(Apelação Cível no 7.174.787-8, $21^{\mathrm{a}}$ Câmara de Direito Privado do Tribunal de Justiça de São Paulo Desembargador Relator Virgílio de Oliveira Junior, ANADEC x Banco Fininvest, Julg. 19/08/2009).

${ }_{556}$ LEGITIMIDADE PARA AJUIZAR AÇÃO CIVIL PÚBLICA - ASSOCIAÇÕES - REQUISITOS LEGAIS. É parte legítima para a propositura de ação civil pública apenas a entidade associativa que demonstre a representatividade adequada ao grupo que pretende defender em juízo, aferida esta por meio de dois requisitos: a pré-constituição, isto é, a existência da associação há pelo menos um ano antes da propositura da ação e; a pertinência temática, que é a inclusão, entre suas finalidades institucionais, da proteção dos interesses envolvidos na demanda. [...]

Evidentemente não tem legitimidade ativa a entidade de proteção de moradores de uma comunidade para discutir através de ação civil pública práticas comerciais - necessidade de etiquetamento de preços - de uma empresa de produtos de construção distante centenas de quilômetros de sua sede, padecendo de representatividade adequada ao grupo que pretende defender em juízo. (Apelação Cível no 2004.021245-3, $1^{\text {a }}$ Câmara de Direito Público do Tribunal de Justiça de Santa Catarina, Desembargador Relator Nicanor da Silveira, Associação de Moradores Vida Verde e Associação Catarinense de Defesa dos Cidadãos, Consumidores e Contribuintes x Cassol Materiais de Construção LTDA, Julg. 11.05.2006).
} 


\subsubsection{Da pertinência temática como forma de aferir a representatividade adequada}

O requisito da pertinência temática aparece com maior frequência, possivelmente em virtude da possibilidade do juiz desconsiderar a pré-constituição acaso entenda se tratar de caso de manifesto interesse social (Artigo 82, $\$ 1^{\circ}$ do Código de Defesa do Consumidor).

Foi o que se observou na ação civil pública movida pela Associação de Assistência às Famílias Castigadas por Acidentes Aéreos e Tragédias Antigas e Modernas contra a Ordem dos Advogados do Brasil, com o fito de levantar supostas imoralidades no processo eleitoral desta última. Ao julgar o caso, o Tribunal Regional Federal da $3^{\text {a }}$ Região atestou que a associação não tem legitimidade ou representatividade adequada, por não ser vocacionada à defesa da probidade administrativa no âmbito da Ordem dos Advogados do Brasil (OAB) ${ }^{557}$.

Também é o que parece indicar o acórdão do Tribunal de Justiça do Mato Grosso, apreciando caso em que a Associação dos Docentes da Universidade do Estado de Mato Grosso (ADUNEMAT) ingressou com ação contra a referida universidade e também contra à Fundação de Apoio ao Ensino Superior Público Estadual, visando obter prestação de contas dos recursos enviados pelo Estado para a Universidade. A ação foi extinta sem julgamento do mérito em primeiro grau, por ter entendido o juiz que a associação carecia de pertinência temática. A decisão foi mantida no Tribunal de Justiça do Mato Grosso por não ter a associação autora levado aos autos seu estatuto, o que impediu a câmara de analisar o tempo de existência da associação e a pertinência temática, sendo-lhe negada a legitimidade ativa ${ }^{558}$.

\footnotetext{
${ }^{557}$ Apelação Cível no 2003.61.00.033575-9/SP, Relator Juiz Federal Convocado Silva Neto, julgamento em 04.02.2010.

558 "Ultrapassando o introito necessário, verifica-se que a demanda proposta pela apelante tem como objetivo obter informação e explicações da Apelada Faespe, e também da apelada Unemat, de como foram gastos os recursos recebidos no período compreendido entre 2004 até o cumprimento da decisão de mérito, tendo em vista o repasse estadual a falta de transparência quanto à utilização da verba. Ou seja, o objeto da Ação Civil Pública é a prestação de conta do dinheiro público posto sob a responsabilidade das entidades apeladas. Do exame desses autos, vê-se que não há prova do tempo de criação da finalidade da Associação Apelante, que não cuidou de juntar cópia de seu estatuto. O que existe é a fotocópia do estatuto do Sindicato Nacional dos Docentes das Instituições de Ensino Superior - ANDES, consoante se verifica às fls. 46/64, e que não substitui o estatuto da Recorrente. Assim, à míngua da prova do prazo ânuo e da pertinência temática, em especial porque a apelante não demonstrou sua finalidade institucional, não há como concluir que o objeto da ação guarda nexo com os objetivos institucionais, de modo a validar sua legitimidade à luz do art. $5^{\circ}$, inciso, V, da Lei. Nº 7.347/85”. (Apelação nº 30841/2010, Julg. 09.11.2010).
} 


\subsubsection{O caso da Associação de Bares e Restaurantes Diferenciados (ABREDI)}

É preciso anotar, no entanto, que, em muitos casos, ainda que utilizados os parâmetros legais - particularmente a pertinência temática -, os juízes têm saído da superfície da análise da letra fria da lei e dos estatutos para contemplar casos em que a falta de pertinência temática depende de uma interpretação conjunta com a atuação das associações na prática, e não só do texto de seus atos constitutivos. Nesses casos, os tribunais justificam que falta representatividade adequada à associação que não age de acordo com as suas finalidades institucionais, ou que incluem finalidades pro forma.

É o que pode ser observado nos acórdãos que julgaram as diversas apelações nos autos de Ações Civis Públicas propostas pela Associação de Bares e Restaurantes Diferenciados (ABREDI) contra a Companhia de Saneamento Básico do Estado de São Paulo (SABESP) e o Serviço Municipal de Água e Saneamento Básico de Santo André (SEMASA). Várias ações civis públicas foram propostas, cada uma em uma comarca diferente, sempre pela ABREDI contra a SABESP e o SEMASA ${ }^{559}$, discutindo suposta abusividade na cobrança da multa moratória acima do patamar de $2 \%$ (dois por cento) dos consumidores do estado de São Paulo.

Nos acórdãos analisados ${ }^{560}$, as ações foram extintas em primeira instância, sem o julgamento do mérito, por ter se considerado que a Associação de Bares e Restaurantes Diferenciados não guarda relação direta com o direito do consumidor e, estando ausente a pertinência temática, não há que se falar em legitimidade ativa para a defesa desse tipo de direito. Os recursos de apelação, interpostos pela associação sucumbente, foram julgados pelo Tribunal de Justiça de São Paulo no curso de aproximadamente dois anos, o que permitiu às Câmaras Cíveis apreciarem a atuação da entidade em questão ao longo do tempo - e isso refletiu diretamente na formação da convicção dos julgadores.

A primeira apelação, entre as selecionadas, foi julgada pela $32^{\mathrm{a}}$ Câmara de Direito Privado do Tribunal de Justiça de São Paulo em dezembro de 2009. No acórdão foi reconhecida a ilegitimidade ativa da associação autora, por falta de pertinência temática e, por conseguinte, de representatividade adequada. O relator Walter Cesar Exner ressalta, em

559 Cite-se como exemplo a apelação no 0055615-34.2007.8.26.0000 foi tirada de ação proposta pela ABREDI contra a SEMASA (Serviço Municipal de Saneamento Ambiental de Santo André). As demais foram propostas contra a SABESP. Os resultados, pela ilegitimidade ativa da autora, no entanto, foram consistentes em todos os casos.

${ }^{560}$ Foram selecionados quatro acórdãos, de um universo de vinte e dois envolvendo as mesmas partes e a mesma controvérsia. 
um trecho de seu voto, a insuficiência da mera menção a uma finalidade institucional genérica para que lhe seja atribuída legitimidade ativa para a propositura de ações na defesa da coletividade. Esse era o caso da ABREDI que, conquanto se colocasse como associação que congregava bares e restaurantes, incluiu em seus estatutos a finalidade de "propor e implementar ações populares civis ou públicas e todas as demais ações e atividades que visem defender os interesses do setor e da sociedade: patrimônio, histórico,cultural, direitos humanos, meio ambiente, ética na atividade pública e privada, interesses coletivos e demais do mesmo gênero" ${ }^{, 561}$.

No ano de 2011, a 25 $5^{\mathrm{a}}$ Câmara de Direito Privado do Tribunal de Justiça de São Paulo julgou dois recursos diversos, ambos resultantes das ações propostas pela ABREDI contra a SABESP. Na primeira delas, julgada em abril de 2011, o acórdão assinalou a ausência de legitimidade porque a associação não poderia atuar em nome dos consumidores em geral, já que não incluía entre suas finalidades institucionais esse objetivo. Poderia, no máximo, agir em nome de seus associados, no sistema de representação e não de substituição processual, uma vez que se não permite o ingresso de qualquer indivíduo, também não poderá pretender agir em nome da coletividade. Mais do que isso, considera que a presunção de que a associação representa os interesses que declara no estatuto é relativa, podendo ser afastada caso não se reflita na prática. É o que se depreende do seguinte trecho do acórdão em questão:

[...] Ora, ao conferir legitimidade ativa para as ações coletivas em geral a entes públicos, sobretudo ao Ministério Público, o ordenamento jurídico parte do pressuposto de que tais entidades, presumivelmente, representam o chamado interesse público, da mesma forma que pressupõe que as associações agem no presumível interesse dos respectivos filiados.

Obviamente, tal presunção de representação não haverá se a entidade se dedicar, prioritariamente, a fins institucionais outros que não a proteção daqueles interesses que pretende ver atendidos em juízo.

\footnotetext{
561 "Com efeito, embora seja incontroverso que a associação autora fora constituída há mais de um ano do ajuizamento da presente demanda, deixa ela de preencher o requisito atinente à finalidade institucional da associação. De fato, muito embora conste do art. $3^{\circ}$, alínea "f" do Estatuto Social da apelada, que uma de suas finalidades é "propor e implementar ações populares civis ou públicas e todas as demais ações e atividades que visem defender os interesses do setor e da sociedade: patrimônio, histórico, cultural, direitos humanos, meio ambiente, ética na atividade pública e privada, interesses coletivos e demais do mesmo gênero" (fls. 28/29), nota-se, pelas próprias pessoas jurídicas que agrega, que a tutela dos interesses dos consumidores em nada diz com seus reais objetivos estatutários, nada mudando este cenário a previsão meramente formal e genérica retro mencionada. Falta-lhe, pois, a denominada representatividade adequada, que é aferida pelas condições temporal e institucional previstas no artigo 82, inciso IV do CDC. [...]" (Apelação Cível no 992.05.126281-8, 32a Câmara de Direito Privado do Tribunal de Justiça de São Paulo, Desembargador Relator Walter Cesar Exner, ABREDI Associação de Bares e Restaurantes Diferenciados X Companhia de Saneamento Básico do Estado de São Paulo - SABESP, Julg. 17.12.2009 - grifos e destaques no original).
} 
É bem essa a hipótese dos autos: a associação apelante, é fácil perceber, foi constituída e se destina à salvaguarda dos interesses de empresas dedicadas às atividades de bar e restaurante.

Bem é de ver terceiros, que não empresas destinadas a tais atividades econômicas, não podem nem mesmo se filiar à associação apelante (v. estatutos, arts. $1^{\circ}$ e $2^{\circ}$, fl. 28$)$.

Logo, com o máximo respeito, soa absurdo afirmar que tal associação dispõe de legitimidade para vir a juízo na defesa de interesses que não dos respectivos filiados.

Para que tal ampla legitimidade existisse, e assim devem ser interpretados os dispositivos acima transcritos, seria de mister que a proteção dos interesses difusos e coletivos a que aludem as normas representassem a finalidade institucional prioritária da entidade associativa (ainda que não fosse a única) e que, de conseguinte, os respectivos estatutos facultassem a filiação de todo aquele indivíduo que tivesse ou pudesse ter interesse na preservação daquele bem jurídico. Só assim, com efeito, será possível dizer que a entidade representa legitimamente a massa daqueles com interesses na preservação daquele dado bem jurídico.

Do contrário, abertas estariam as portas largas para a instalação de verdadeira babel, pois que indivíduos sem nenhuma representatividade estariam autorizados a vir a juízo pleiteando a tutela com força de coisa julgada e eficácia "erga omnes" sobre temas de interesses de terceiros, completamente alheios à iniciativa e cujos interesses poderiam, em tese, ser visceralmente contrariados com a providência almejada pelo sedizente substituo processual [...] ${ }^{562}$ (grifos e destaques no original)

Meses depois, em setembro de 2011, a mesma Câmara e o mesmo Relator recepcionaram outro recurso, tirado de Ação Civil Pública idêntica. Nesse caso, no entanto, restou claro o modus operandi da associação em questão. Em primeira instância, a entidade fora condenada ao pagamento de multa por litigância de má-fé, vez que ingressara com diversas ações civis públicas quando uma só seria suficiente para atender ao intento pretendido. O Tribunal de Justiça de São Paulo manteve a condenação por litigância de má-fé fixada em primeiro grau por ter entendido que a associação em questão fez mau uso da ação coletiva ${ }^{563}$.

Assim, parece seguro afirmar que tais acórdãos adotam uma postura mais rígida quanto ao requisito da pertinência temática, saindo da superfície do texto do estatuto da associação em questão - que, a rigor, permitia o ajuizamento de ações para a defesa dos

\footnotetext{
${ }^{562}$ Trecho do acórdão da Apelação Cível no 9101496.12.2006.8.26.0000, 25 ${ }^{\text {a }}$ Câmara de Direito Privado do Tribunal de Justiça de São Paulo, Desembargador Relator Ricardo Pessoa de Mello Belli, ABREDI Associação de Bares e Restaurantes Diferenciados x Companhia de Saneamento Básico do Estado de São Paulo - SABESP, Julg. 18.04.2011.

563 [...] Por todo o exposto e, mais, por fazer uso indiscriminado desta ação coletiva - haja vista o semnúmero de ações idênticas por ela proposta -, quando lhe seria perfeitamente possível aguardar o resultado da ação civil pública proposta nesta Capital, que teria, insisto, eficácia em todo âmbito do Estado de São Paulo, foi acertada a decisão de primeiro grau ao reputar a apelante litigante de má-fé. [...] (Apelação Cível $\mathrm{n}^{\circ}$ 9132290-16.2006.8.26.0000, 25 ${ }^{\text {a }}$ Câmara de Direito Privado do Tribunal de Justiça de São Paulo, Desembargador Relator Ricardo Pessoa de Mello Belli, ABREDI Associação de Bares e Restaurantes Diferenciados x Companhia de Saneamento Básico do Estado de São Paulo - SABESP, Julg. 14.09.2011 grifos e destaques no original).
} 
"interesses da sociedade", o que incluiria a defesa do consumidor - para verificar qual a proposta inicial da entidade e, por conseguinte, que tipo de associados e interesses congregava. No caso, entendeu-se que a previsão genérica do estatuto não é suficiente para demonstrar a representatividade adequada da associação em matéria afeita ao direito do consumidor. Sua finalidade precípua é a defesa dos interesses de bares e restaurantes, que são seus associados. Equivale dizer que a presunção de representatividade de uma associação pode ser afastada nos casos em que a defesa dos interesses listados em seu estatuto não se convalide na prática.

Essa situação apreciada nos acórdãos supracitados é análoga àquela relatada no capítulo anterior, em que uma associação de defesa de fumantes propõe Ação Civil Pública pleiteando pagamento de expurgos inflacionários de planos econômicos, entendendo-se legítima para tanto pelo simples fato de incluir em seu estatuto a finalidade de defesa do consumidor. Da mesma forma que a ABREDI não foi considerada legítima para defender os interesses de todos os consumidores de água - a despeito de previsão estatutária genérica que, no rigor da lei, lhe permitisse -, por ter finalidade primária de defender os interesses de uma determinada e delimitada classe, associações como aquela de defesa dos fumantes também não poderiam ser consideradas legítimas para defender os interesses dos consumidores de serviços bancários ${ }^{564}$.

Assim, conquanto a análise perpetrada pelos tribunais pátrios nesses acórdãos se limite à aplicação dos critérios legais, que, aqui, defendeu-se não serem a expressão da representatividade adequada, é certo que tais critérios prestam-se a impedir que associações inaptas ou mesmo inidôneas tenham acesso ao judiciário para supostamente defenderem os direitos da coletividade. Com isso, é forçoso reconhecer que os requisitos legais, os quais são insuficientes para aferir a adequação do representante, têm sido utilizados pela jurisprudência para essa finalidade de maneira satisfatória - especialmente quando se sai da superfície dos textos dos estatutos para interpretá-los de acordo com a lei e com os parâmetros estabelecidos pela boa-fé.

${ }^{564}$ Sobre as ações propostas pela ACEDESFE e suas disposições estatutárias ver capítulo 6, subitem 6.2.2. 


\subsection{DEMAIS CRITÉRIOS QUE VÊM SENDO ESTABELECIDOS PELA JURISPRUDÊNCIA PARA AFERIR A REPRESENTATIVIDADE ADEQUADA DAS ASSOCIAÇÕES}

Em que pese a orientação majoritária da jurisprudência, quanto à limitação da análise da representatividade adequada das associações aos critérios estabelecidos pela legislação, é possível observarum aumento gradativo da preocupação dos juízes com a efetiva aptidão das entidades associativas para representar não apenas seus associados, como também toda a coletividade. Há, ainda, uma crescente preocupação com a idoneidade dessas associações, traduzida no comportamento por elas adotado no curso dos processos. E disso tem resultado uma ampliação da visão dos julgadores, os quais têm buscado elementos a partir de uma interpretação integrada da legislação, ou mesmo na cláusula geral da boa-fé e no repúdio ao abuso de direito ${ }^{565}$, para verificar a representatividade adequada de determinadas associações em relação aos interesses que se propõem a defender. Essa tendência se traduz em alguns julgados em que se sai da superfície do texto legal para aferir a representatividade adequada das entidades associativas, a partir de uma análise mais aprofundada.

Como anteriormente explorado, conquanto seja recomendável positivar a possibilidade de aferição ope judicis da representatividade adequada, bem como parâmetros para que os juízes realizem essa verificação, o controle desse requisito não é vedado aos magistrados atualmente, pelo contrário, é possível e necessário ${ }^{566}$. Ademais, existe uma série de dispositivos legais, bem como cláusulas gerais aplicáveis a todas as relações jurídicas, que podem auxiliar na realização desse controle.

\footnotetext{
${ }^{565}$ São as possibilidades de aferição da representatividade adequada, utilizando o quanto já positivado em nosso ordenamento jurídico, exploradas no capítulo 6, subitem 6.2.

${ }^{566}$ Alguns julgados pesquisados, antes de adentrar a análise da legitimidade ativa e da representatividade adequada das associações, fazem remissões a essa possibilidade, como é o caso do Agravo de Instrumento ${ }^{\circ}$ 0880/2009, da primeira Câmara Cível do Tribunal de Justiça de Sergipe, relatado pela Desembargadora Clara Leite de Resende: "No sistema adotado no Brasil, a sentença produz efeitos secundum eventum litis, de modo que o rigor com a adequada representatividade do demandante é menor, havendo até mesmo quem sustente que a legitimidade é determinada apenas de acordo com a previsão legal. Não obstante as razões acima expostas, tanto o Supremo Tribunal Federal quanto o Superior Tribunal de Justiça, bem como invulgar parcela da doutrina esposam a tese segundo a qual é possível e necessária a existência de um controle judicial da representatividade adequada, em cada caso, daqueles autorizados em lei para a propositura de ações coletivas, o que não raras vezes é referido como um requisito de pertinência temática."
} 


\subsubsection{Do abuso da forma associativa: sociedades travestidas de associações}

\subsubsection{O caso da Associação de Defesa da Cidadania e do Consumidor (ADECON/MS)}

Em primeiro lugar, propôs-se a análise conjunta das regras de atribuição da legitimidade ativa às associações, positivadas no microssistema de processos coletivos - a qualidade de associação, a pertinência temática e a pré-constituição há um ano -, e de outros diplomas legais, como o Código Civil. Este, entre outras coisas, traz positivado em seus artigos 53 e seguintes quais os requisitos necessários para que uma pessoa jurídica seja considerada associação. A legislação, por sua vez, não admite que outras pessoas jurídicas, que não associações civis, ingressem em juízo pretendendo proteger os interesses da coletividade.

Análise dessa natureza foi realizada no seguinte julgado, do Tribunal de Justiça do Mato Grosso do Sul (Apelação Cível no 2008.004641-9, Quarta Turma Cível do Tribunal de Justiça do Mato Grosso do Sul, Desembargador Relator Dorival Renato Pavan, Unibanco x ADECON/MS, Julg. 09/06/2009), que vai à gênese do negócio jurídico que deu origem à associação, bem como à análise da atuação da entidade junto à sociedade civil, para verificar que não se tratava de uma entidade apta a defender os interesses da coletividade - por se tratar de sociedade, e não de associação.

A ADECON/MS (Associação de Defesa da Cidadania e do Consumidor do Mato Grosso do Sul) ingressou com ação civil pública pretendendo a condenação da instituição financeira ao pagamento de expurgos inflacionários dos planos econômicos. Em primeira instância, a sentença foi de procedência, sem que fossem analisadas as matérias levantadas pelo réu, em especial aquelas atinentes à falta de legitimidade ativa da associação por abuso da forma associativa. Em recurso de apelação, tal matéria foi devolvida ao Tribunal de Justiça do Mato Grosso do Sul. A verificação do estatuto, conjuntamente com a forma como a pessoa jurídica agia na prática, permitiu à Quarta Turma Cível do TJMS declarar a nulidade dos atos constitutivos da entidade, descaracterizando-a como associação para, com isso, negar a legitimidade ativa para a propositura de Ação Civil Pública.

Em um primeiro momento, o desembargador relator Atapoã da Costa Feliz analisou a questão da legitimidade ativa da associação pelo viés dos requisitos legais - a préconstituição há um ano e a pertinência temática -, concluindo pelo integral preenchimento desses requisitos e, portanto, atribuindo legitimidade à ADECON, no que foi acompanhado 
pelo desembargador revisor ${ }^{567}$. Foi o terceiro componente da turma julgadora desembargador Dorival Renato Pavan - que alertou os demais para a peculiaridade do caso e a necessidade de se aprofundar na leitura do estatuto para, com isso, ter uma visão mais completa da atuação da entidade que, em seu entender, não poderia ser considerada associação, mas verdadeira sociedade de advogados:

Tenho conhecimento de que o SUPERIOR TRIBUNAL DE JUSTIÇA já definiu a orientação jurisprudencial no sentido de que as associações fundadas para defesa do consumidor podem propor ações como a presente, sendo detentoras de legitimidade ativa, e exemplo disso são os inúmeros acórdãos naquele E. Tribunal Superior em relação às ações intentadas, por exemplo, pela Associação Paranaense de Defesa do Consumidor - APADECO.

A espécie dos autos, entrementes, é peculiar, e tal peculiaridade decorre do exame do estatuto associativo juntado com a inicial, às f. 17-22, que leva à adoção de um entendimento diametralmente oposto, fundado na prova dos autos. Examinando-se detidamente referido Estatuto, constata-se que não há, ali, a especificação de quais são os requisitos para a admissão, demissão e exclusão de associados, exigência clara e rigorosa do artigo 54, II, do Código Civil, fulminando de nulidade o Estatuto Social que assim não dispor. [...]

Nem de longe, então, os dispositivos do Estatuto Social da associação autora atendem ao comando inserto nos artigos 54, II, e 57, do Código Civil de 2002, sob cuja égide já houve sua fundação, transparecendo que a entidade autora tratase, na realidade, de uma sociedade de advogados, com a roupagem de uma associação, o que se revela como desvio de finalidade.

O caráter social é muito mais eminente do que o caráter associativo da entidade autora, não importando, no caso, a denominação que se lhe emprestou o estatuto ou mesmo a descrição de suas finalidades.

O que importa é aferir se as disposições estatutárias se afinam com a lei e, no caso, tal não ocorre, revela, portanto, a ilegitimidade ativa da entidade autora, em que pese o fato de se autodenominar associação quando, em realidade, é muito mais sociedade de pessoas, constituída para fins determinados e que por isso mesmo não se encontram ao albergue do artigo $5^{\circ}$, V, da Lei 7.347, de 24.07. $85^{568}$.

E o desembargador vogal vai além e destrincha os termos do estatuto para concluir que a estrutura da associação está amalgamada com a estrutura do escritório de advocacia que a representa em juízo, sendo que o presidente e vice-presidente eram também os advogados subscritores da petição inicial e todos os demais associados eram, também,

567 “Com relação à preliminar de ilegitimidade ativa da Associação de Defesa do Consumidor de Mato Grosso do Sul - ADECON/MS -, observa-se que, por se tratar de uma associação civil, sem fins lucrativos, que inclui entre suas finalidades a defesa dos interesses do consumidor em juízo (artigo 2, alíneas "a", "b", "e" e "f", do seu estatuto - f. 46 e 47 dos autos), enquadra-se na hipótese do inciso II do artigo $5^{\circ}$ da Lei n. $7.347 / 85$, é, portanto, uma das entidades legitimadas à propositura da ação civil pública.

Logo, a ADECON/MS detém legitimidade ativa para ajuizar ação civil pública com o escopo de cobrar diferenças nos créditos de rendimentos dos aplicadores de cadernetas de poupança. Afasta-se, assim, a preliminar de ilegitimidade ativa." (Apelação Cível no 2008.004641-9, Quarta Turma Cível do Tribunal de Justiça do Mato Grosso do Sul, trecho do voto do relator).

568 Apelação Cível no 2008.004641-9, Quarta Turma Cível do Tribunal de Justiça do Mato Grosso do Sul, trecho do voto do terceiro desembargador. 
advogados. A associação e o escritório dos advogados em questão compartilhavam, ainda, o mesmo endereço. Ressalta, por fim, que a atitude da associação autora não só fere o quanto previsto no Código Civil para a constituição de associações e no Código de Defesa do Consumidor no que toca à atribuição de legitimidade ativa a essas entidades mas, também, diversos dispositivos do Código de Ética e Disciplina da Ordem dos Advogados do Brasil $^{569}$. Com fundamento em tudo isso, acolheu em seu voto a preliminar de ilegitimidade ativa, no que foi, posteriormente, acompanhado pelo desembargador revisor, o qual alterou seu voto antes da proclamação do resultado do julgamento, tendo sido extinta a ação civil pública sem resolução do mérito por maioria de votos.

O julgado acima relatado, aplicando os dispositivos do Código Civil, identificou desvio da forma associativa perpetrado pela ADECON/MS. Como reiteradamente se discutiu neste estudo, não é o nome que se dá à pessoa jurídica que define sua natureza, mas a forma como esta desenvolve as atividades a que se propõe ${ }^{570}$. Se a entidade se estruturou de forma a se identificar com uma verdadeira sociedade de advogados, certamente não poderá ser considerada como associação, muito embora assim se autodenomine.

Ademais, para além da infringência direta aos dispositivos de lei que atribuem a legitimidade ativa às associações - i.e. se a pessoa jurídica não é associação, não poderá propor ações coletivas -, identifica-se claro abuso do direito de demandar. Isso porque o abuso perpetrado no campo do direito material, na constituição da associação mediante

\footnotetext{
569 “a) - o valor atribuído à causa foi de $\mathrm{R} \$ 5.000 .000,00$ (cinco milhões de reais), bastante expressivo; b) - a entidade autora outorgou mandato aos Drs. Felipo Cazuo Azuma e Fábio Nogueira da Costa, que subscreveram a inicial (f. 14 e 15), e, no ato de constituição da associação (f. 16-verso), o Presidente foi designado na pessoa de, nada mais nada menos, Felipo Cazuo Azuma, cabendo ao outro causídico, Fábio Nogueira da Costa,a Vice-Presidência. b) - todos os demais associados são, de igual forma, advogados, como se constata da mera leitura da ata de f. 16, ou seja, são advogados o Secretário-Geral (Rodrigo Ruiz Rodrigues) e o Tesoureiro (Leopoldo M. Azuma). Consta ali como associada, mas sem discriminar sua qualificação - provavelmente advogada também - Karla Cristina Basso Azuma. c) - o endereço da associação: Rua Eduardo Santos Pereira, 322, Sobre-loja, Jardim Anfe, em Campo Grande-MS. d) - o endereço do advogado FÁBIO NOGUEIRA COSTA, mencionado no instrumento de mandato de f. 15: Rua Eduardo Santos Pereira, 322, Vila Anfe, em Campo Grande, MS, "onde recebe intimações" (f. 15). [...] Associação com tais características tem finalidade desvirtuada e não se presta à defesa dos interesses do consumidor, tal como objetivado pela lei da ação civil pública e pelo Código de Defesa do Consumidor, não se podendo lhe atribuir legitimidade para postular pela presente ação em juízo, só pelo simples fato de se autodenominar associação, quando os elementos probatórios constantes dos autos evidenciam o desvirtuamento de sua finalidade, fato que merece ser mais bem investigado tanto pela Ordem dos Advogados do Brasil, quanto pelo Ministério Público do Estado de Mato Grosso do Sul, para quem cópias deste voto, da inicial e documentos que a instruíram, deverão ser enviadas, tanto que transite em julgado. $[\ldots] "$

${ }^{570}$ No capítulo 3 citou-se a jurisprudência do Superior Tribunal de Justiça, no sentido de que o nomen juris é irrelevante para a qualificação de uma pessoa jurídica como sociedade ou não, já que isso é definido pela sua finalidade econômica (Recurso Especial no 449901/BA, Min. Rel. Luiz Fux, Primeira Turma, Julgamento 17/12/2002) . Ver Capítulo 3, subitem 3.4.
} 
desvio de forma, desborda para o processo, já que uma sociedade não pode ingressar com ação civil pública ${ }^{571}$.

\subsubsection{O caso do Instituto de Defesa do Consumidor e do Contribuinte (IDC/SC)}

A preocupação em se verificar o negócio jurídico que deu origem à associação, ainda é minoritária - vale dizer, residual -, mas não se restringe a um só acórdão. $\mathrm{O}$ Tribunal de Justiça de Santa Catarina também já apreciou situação análoga, em que houve a simulação de criação de uma associação sem fins lucrativos, que, na realidade, era uma sociedade de advogados com a possibilidade de ingressar com ações civis públicas e receber honorários.

Essa questão foi analisada em acórdão prolatado pela $1^{a}$ Câmara de Direito Público de Santa Catarina, em ação proposta pelo Instituto de Defesa do Cidadão (IDC) contra o Banco do Estado de Santa Catarina, a qual também tinha como objetivo reaver expurgos inflacionários. A sentença extinguiu o processo por falta de legitimidade ativa da entidade associativa, por esta não preencher o requisito da pré-constituição há um ano. $\mathrm{O}$ acórdão estudado manteve a sentença, observando que a associação não tinha representatividade adequada suficiente para que fosse dispensado o requisito da pré-constituição nos termos do artigo $82, \S 1^{\circ}$ do Código de Defesa do Consumidor ${ }^{572}$.

Os motivos destacados pelo desembargador vão desde a excessiva amplitude de finalidades institucionais da indigitada associação - cujo estatuto lhe permitia defender todo e qualquer interesse difuso ou coletivo - até indícios de que a associação não passava de uma fachada para a atuação de escritório de advocacia. Nesse último tocante, a exemplo do que fora realizado pelo desembargador no caso da ADECON, o julgador cita: a composição da associação por advogados e seus parentes; o fato de que a Assembleia Geral de criação da entidade se deu no escritório de advocacia dos procuradores que subscreviam a ação civil pública; possível coincidência de endereço; e, por fím, a

\footnotetext{
${ }^{571}$ Conforme discutido no capítulo 6 deste estudo, sobre o abuso do direito de demandar, no que diz respeito à constituição das associações, a titularidade de um direito e a aparência de legalidade do ato praticado correspondem ao direito de livre associação e ao registro de estatutos aparentemente na forma da lei, respectivamente. Já no que toca ao direito processual, o direito exercido é o direito de demandar (preconizado pelo artigo $5^{\circ}$, XXXV da Constituição Federal) e a aparência de legalidade é determinada pela atribuição de legitimidade às associações que preencherem, ou aparentemente preencherem, os requisitos já mencionados (pré-constituição há um ano e pertinência temática). Capítulo 6, subitem 6.1.2.

572 Apelação Cível no $2005.017940-3,1^{a}$ Câmara de Direito Público do Tribunal de Justiça de Santa Catarina, Des. Rel. Nicanor da Silveira, IDC - Instituto de Defesa do Cidadão x Banco do Estado de Santa Catarina, julg. 13.10.2005.
} 
inexistência de qualquer outra atuação da associação que não fosse a propositura de ações civis públicas $^{573}$.

Esse acórdão do Tribunal de Justiça de Santa Catarina analisa também outros pontos interessantes. Ainda no que toca à caracterização das entidades como associações, alguns tribunais têm utilizado como parâmetro para aferir a representatividade o número de associados que elas congregam. Trata-se, aqui, de uma forma de verificar o requisito da união de pessoas que, em última análise, caracteriza uma entidade como associação enquanto pessoa jurídica que congrega indivíduos com interesses comuns ${ }^{574}$. E conquanto o ordenamento jurídico brasileiro não estabeleça limites máximos ou mínimos de associados para que se caracterize uma associação, os julgadores têm usado essa via para

573 "Há que se sopesar o requisito processual da pré-constituição da associação demandante com o bem
jurídico que se pretende tutelar através da prestação jurisdicional. In casu, não demonstradas a evidente
relevância para a sociedade e a representatividade do Instituto de Defesa do Cidadão, é impossível a
aplicação do §1 $1^{\circ}$ do art. 82 da legislação consumerista, que dispensa a exigência.
RECURSO DESPROVIDO. [...] Ademais, o estatuto do autor desta demanda não se coaduna com as
exigências para a constituição de uma associação civil no elevado reclamo do artigo $5^{\circ}$ da lei $7.347 / 85$, posto
que chega a se confundir com as atribuições do próprio Ministério Público, quando, em seu art. $2^{\circ}$, informa
que a finalidade do Instituto é essencialmente "promover a defesa dos cidadãos e consumidores em geral, de
acordo com as normas do código de Defesa do Consumidor e legislação correlata, como também dos
contribuintes e quaisquer outras pessoas, relativamente aos danos causados a tais pessoas, bem como ao meio
ambiente, e ainda, a qualquer outro interesse difuso ou coletivo, na forma da lei de Ação Civil Pública e
legislação vigente."
É de se observar, também, que a reunião da Assembléia Geral que criou o Instituto apelante ocorreu no
escritório de advocacia Boldori, e foi presidida pelo advogado Marcelo José Boldori, Coordenador Geral da
dita sociedade civil sem fins lucrativos. Constou da mesma Ata que o local de funcionamento provisório seria
a residência situada na Rua Dr. Leoberto Leal, ${ }^{\circ} 291$, que é o endereço residencial do citado advogado e,
também, da Conselheira Fiscal Mariane C. Boldori. Certamente para ocultar tal fato, o estatuto deixou de
mencionar o endereço da sede do Instituto, limitando-se a dizer que sua localizaçãa é no município de Porto
União (artigo $1^{\circ}$ ), o que feriu o disposto no artigo 19 do antigo Código Civil, comando repetido na lei
$10.406 / 02$, que previu a obrigatoriedade de previsão da designação de sede das associações, sob pena de nulidade.

A evidência da formação fraudulenta fica ainda mais saliente, ao constatar-se que a Coordenadora Financeira Patrícia P. R. Fronczak e a Coordenadora Administrativa Arlete T. B. Pacheco dos Santos possuem parentesco com os procuradores do apelante.

Vale ressaltar que, em consulta formulada no site do citado instituto (www.idc-br.org), verifica-se a inexistência de qualquer ação extrajudicial no sentido de se fazer a alegada defesa dos direitos do cidadão, mas tão-somente as diversas ações civis públicas ajuizadas, todas exclusivamente com o mesmo objetivo constatado no caso em exame.

Pelo até aqui aduzido, é imperioso destacar que, além da flagrante ilegitimidade de parte para a propositura da presente ação civil pública, há nulidades no estatuto da sociedade civil recorrente, razão apta a ensejar sua anulação.

Por conseguinte, desde já se requer o encaminhamento dos autos à Corregedoria-Geral de Justiça, para os devidos fins $[\ldots]$

O que se observa dos autos é verdadeira simulação com a criação de uma sociedade civil, supostamente sem fins lucrativos, porém com o notável objetivo de perceber verbas honorárias, conforme se observa do pedido formulado às folhas 12 e 156. Não se pode admitir, neste contexto, verdadeira captação de clientela por meio da ação civil pública. Aliás, foi isto que, acertadamente, procurou impedir o legislador ao elaborar a lei $\mathrm{n}^{\circ}$ 7.347/85. Em face do alegado, requer-se a decretação de extinção do feito sem julgamento do mérito, com fundamento no artigo 267, inciso VI, da lei Adjetiva Civil (fls. 195/199)".

${ }^{574}$ Cf. capítulo 3, subitem 3.3.1. 
verificar a representatividade adequada ${ }^{575}$ - sem nem adentrar no campo da adequação. Ou seja, adotando esses parâmetros, os juízes procuram responder à seguinte indagação: determinada associação representa os interesses de alguém ou apenas daqueles que a constituíram?

Quanto a esse ponto, o acórdão supracitado ressalta que o IDC carece de representatividade adequada e, portanto, de legitimidade, em virtude, também, de ser integrado por apenas seis membros - o que se depreende de seu estatuto -, não tendo, portanto, sequer integrantes suficientes para eleger suplentes aos cargos do conselho fiscal - órgão este previsto no estatuto da associação. Esse fato, para além das outras irregularidades destacadas no acórdão, denotaria a falta de representatividade da associação, visto que ela sequer conta com um número significativo de associados para que possa ser considerada um centro de agregação de interesses ${ }^{576}$.

Percebe-se, portanto, que a análise da atuação das associações na prática, seja para verificar se efetivamente atuam como uma entidade sem fins lucrativos - para além da autodenominação como associação -, seja para aferir se efetivamente representam alguém, se congregam indivíduos com interesses comuns, tem servido como um parâmetro para os juízes verificarem a representatividade adequada de entidades associativas com o intuito de negarem ou conferirem a elas legitimidade ativa para propor ações coletivas. O resultado disso é que às entidades que atuam em claro desvio de finalidade ou àquelas que não demonstram representar um determinado número de associados tem sido negada a legitimidade ativa, por se entender que falta a elas idoneidade suficiente para caracterizar a representatividade adequada.

\footnotetext{
${ }^{575}$ Cf. capítulo 3, subitem 3.3.1.

576 “....] Outra questão a ser abordada diz respeito à representatividade exigida para os legitimados à propositura de ações civis públicas, requisito não atendido pelo apelante no caso vertente, diante da leitura de seu estatuto, o qual, por sinal, conta com diversas irregularidades. $\mathrm{O}$ artigo $3^{\circ}$ (fls. 17-21) diz serem sócios fundadores os que efetivamente assinarem a ata de fundação e, neste contexto, que só podem ser admitidos como sócios efetivos os indicados por três sócios componentes do Instituto, mediante aprovação da assembléia geral. Com efeito, o artigo 37 do referido estatuto consigna os membros da Diretoria, quais sejam, o Coordenador-Geral Marcelo José Boldori, Coordenador Financeiro Patrícia Paula Ruaro Fronczak, Coordenador Administrativo Arlete Terezinha Bazzo Pacheco dos Santos, e, no artigo 37, arrola os membros efetivos do Conselho Fiscal, constituído por Alexandra Breyer, Kátia Regina Santos Oliveira e Mariane Cristina Boldori, perfazendo um total de seis membros. Ora, pela leitura do próprio estatuto, conclui-se que, além dos três membros componentes da Diretoria, faz-se necessário mais seis membros para compor o Conselho Fiscal, constituído por apenas três conselheiros, pois não foram eleitos os membros suplentes, em flagrante desobediência ao disposto no artigo 14, obviamente em razão do instituto contar com apenas seis sócios.

Por óbvio, uma associação, ou, no caso vertente, sociedade civil composta por apenas seis pessoas, ainda mais diante das irregularidades descritas, não possui a representatividade pretendida pela lei da Ação Civil Pública."
} 
Como já se analisou no capítulo anterior, essas atitudes das entidades associativas podem ser caracterizadas como abuso de direito de demandar, conflitando com o valor fundamental da boa-fé. Atuação dessa natureza, que deixa claro o objetivo econômico da associação, bem como a utilização das ações civis públicas para a obtenção de vantagens econômicas, vai contra o requisito da representatividade adequada, que preconiza uma atuação vigorosa, completa e idônea dos interesses da coletividade substituída no processo. Ora, se uma entidade está a perseguir seus próprios interesses, consubstanciados no lucro que pretende auferir com determinada ação, claramente deixou em segundo plano a defesa dos interesses transindividuais.

\subsubsection{Do abuso de direito: condutas contrárias à boa-fé}

7.2.2.1. O caso da Associação Nacional de Assistência ao Consumidor e ao Trabalhador (ANACONT): venda de sentenças

Foi com base nessas premissas, de que a associação não pode perseguir finalidades lucrativas por meio da propositura de ações coletivas, que o Tribunal de Justiça do Rio de Janeiro negou a legitimidade ativa, por maioria de votos, à ANACONT (Associação Nacional de Assistência ao Consumidor e Trabalhador), mesmo depois de ter sido julgada procedente em primeira instância a ação proposta contra a rede varejista C\&A e contra a Inovacard Administradora de Cartões. Os julgadores deixaram claro que a falta de representatividade adequada foi verificada por fatos ocorridos no curso da demanda.

A associação autora, a ANACONT, após obter a sentença de parcial procedência em primeira instância, passou a distribuir panfletos nas ruas do Rio de Janeiro, veiculando a informação de que pela quantia de $\mathrm{R} \$ 30,00$ (trinta reais) qualquer pessoa poderia obter uma cópia da sentença - diga-se, ainda não transitada em julgado - e procurar a empresa ré para celebrar acordo. O acórdão da $3^{\text {a }}$ Câmara Cível do Tribunal de Justiça do Rio de Janeiro narra o ocorrido:

De outro turno, o documento de fls. 584, intitulado "AÇÃO COLETIVA CARTÃO C\&A - LEIA COM ATENÇÃO” não contribui para a melhor credibilidade da conduta da Autora, expressando um prospecto de inscrição automática, mediante o pagamento de uma taxa de inscrição de $\mathrm{R} \$ 30,00$, na ação civil pública em tela, inclusive mencionando, estranhamente, que " $O$ associado receberá uma cópia da sentença da AÇÃO COLETIVA para junto às empresas INOVACARD ADMINISTRADORA DE CARTÕES DE CRÉDITO e 
C\&A MODAS efetuarem um acordo pelo que foi decidido na justiça". 577 (destaques no original).

\subsubsection{Do abuso de direito: excessiva amplitude das finalidades institucionais}

Por fim, outra forma de controle da representatividade adequada pelos tribunais se observa quando o requisito da pertinência temática das associações autoras é analisado pelos os juízes com maior vagar, anotando que algumas delas descrevem finalidades institucionais excessivamente genéricas em seus estatutos, incluindo a defesa de toda sorte de direitos difusos, coletivos e individuais homogêneos. Esse tipo de manobra tem, em geral, o fito de permitir que tais entidades ingressem com o maior número possível de demandas, uma vez que a lei se limita a falar que a finalidade buscada com a ação deve estar prevista no estatuto da associação.

Como discutido anteriormente, a intenção desse dispositivo, que limita a legitimidade ativa de uma associação para atuar no interesse de terceiros às suas finalidades institucionais, se funda na necessidade de especialização da entidade em uma ou algumas matérias específicas, até para que possa defender os direitos que delas decorrem com a propriedade necessária. No entanto, uma vez que a legislação faz referência apenas a necessidade de constar entre as finalidades da entidade os direitos que ela pretende defender, não é raro surgirem associações que contemplam a defesa dos direitos mais diversos e dissonantes, o que deixa entrever a inviabilidade de uma defesa séria, idônea e vigorosa.

Ademais, a excessiva amplitude das finalidades institucionais torna nebuloso o vínculo entre a atuação da entidade e os interesses daqueles que se associam a ela. Em outras palavras, a relação de pertinência exigida entre o objeto da ação e o objeto da associação privada que a move não se desconecta da relação entre este objeto da entidade e o interesse de seus membros ${ }^{578}$.

Nesse sentido, entendeu o Superior Tribunal de Justiça que a exigência da pertinência temática entre determinada entidade e o direito defendido em juízo é indispensável para garantir a representatividade adequada daqueles que não são partes do processo - os terceiros que serão atingidos pelo resultado da demanda.

\footnotetext{
577 Apelação Cível no 02809/2003, $3^{\text {a }}$ Câmara Cível do Tribunal de Justiça do Rio de Janeiro, Des. Rel. Luiz Fernando Ribeiro de Carvalho, ANACONT x Inovacard e C\&A, Julg. 13.04.2004.

${ }^{578}$ Entendimento expendido no acórdão da Apelação Cível n ${ }^{\circ}$ 446.643.5/5- 00, $10^{\mathrm{a}}$ Câmara de Direito Público do Tribunal de Justiça de São Paulo, Des. Rel. Antonio Celso de Aguiar Cortez, Julg. 26/10/2009. Nesse julgado, negou-se a legitimidade de uma associação com amplíssima finalidade estatutária.
} 
Exemplo dessa orientação está expresso no acórdão relatado pelo Ministro Luiz Fux, apreciando a legitimidade de sindicato para a propositura de ação coletiva em benefício da categoria que representa e afirmando a importância da pertinência temática para a configuração da representatividade adequada. No curso de sua fundamentação, o Ministro cita trecho da doutrina de Hugo Nigro Mazzilli em que se defende que uma desmedida amplitude das finalidades institucionais desnatura a exigência da pertinência temática e colide com a ideia de representatividade adequada ${ }^{579}$.

\subsubsection{O caso da Associação de Proteção e Assistência ao Cidadão (ASPAC)}

O acórdão do Recurso Especial no 901936/RJ descrito acima, bem como a doutrina nele citada, vem sendo utilizado como fundamento para negar a legitimidade ativa às associações que apresentaram estatutos com finalidades institucionais genéricas ou excessivamente amplas.

É esse o caso do acórdão prolatado pela Primeira Câmara Cível do Tribunal de Justiça de Sergipe, que julga agravo de instrumento em ação civil pública proposta pela

579 PROCESSUAL CIVIL. ADMINISTRATIVO. AÇÃO CIVIL PÚBLICA. LEGITIMATIO AD CAUSAM DO SINDICATO. PERTINÊNCIA TEMÁTICA. AUSÊNCIA DE INTIMAÇÃO DO MINISTÉRIO PÚBLICO FEDERAL NAS INSTÂNCIAS ORDINÁRIAS. PREJUÍZO INDEMONSTRADO. NULIDADE INEXISTENTE. PRINCÍPIO DA INSTRUMENTALIDADE DAS FORMAS.1. Os sindicatos possuem legitimidade ativa para demandar em juízo a tutela de direitos subjetivos individuais dos integrantes da categoria, desde que se versem direitos homogêneos e mantenham relação com os fins institucionais do sindicato demandante, atuando como substituto processual (Adequacy Representation). 2. A pertinência temática é imprescindível para configurar a legitimatio ad causam do sindicato, consoante cediço na jurisprudência do E. S.T.F na ADI 3472/DF, Sepúlveda Pertence, DJ de 24.06.2005 e ADI-QO 1282/SP, Relator Ministro Sepúlveda Pertence, Tribunal Pleno, DJ de 29.11.2002 e do S.T.J: REsp 782961/RJ, desta relatoria, DJ de 23.11.2006, REsp 487.202/RJ, Relator Ministro Teori Zavascki, DJ 24/05/2004. 3. A representatividade adequada sob esse enfoque tem merecido destaque na doutrina; senão vejamos:

"(...) A pertinência temática significa que as associações civis devem incluir entre seus fins institucionais a defesa dos interesses objetivados na ação civil pública ou coletiva por elas propostas, dispensada, embora, a autorização de assembleia. Em outras palavras, a pertinência temática é a adequação entre o objeto da ação e a finalidade institucional. As associações civis necessitam, portanto, ter finalidades institucionais compatíveis com a defesa do interesse transindividual que pretendam tutelar em juízo. Entretanto, essa finalidade pode ser razoavelmente genérica; não é preciso que uma associação civil seja constituída para defender em juízo especificamente aquele exato interesse controvertido na hipótese concreta. Em outras palavras, de forma correta já se entendeu, por exemplo, que uma associação civil que tenha por finalidade a defesa do consumidor pode propor ação coletiva em favor de participantes que tenham desistido de consórcio de veículos, não se exigindo que tenha sido instituída para a defesa específica de interesses de consorciados de veículos, desistentes ou inadimplentes. Essa generalidade não pode ser, entretanto, desarrazoada, sob pena de admitirmos a criação de uma associação civil para a defesa de qualquer interesse, o que desnaturaria a exigência de representatividade adequada do grupo lesado[...]”. in A Defesa dos Interesses Difusos em Juízo. Hugo Nigro Mazzilii, São Paulo: Saraiva, 2006, p. 277/278 [...]” (AgRg no RESP nº 901936/RJ, Min. Relator Luiz Fux, Primeira Turma do STJ, DJE de 16/03/2009). 
ASPAC contra o Banco Bradesco ${ }^{580}$. Ao receber a Ação Civil Pública, o juiz entendeu que a associação autora deveria demonstrar a sua representatividade no estado de Sergipe, já que pleiteava a devolução de valores pagos a mais pelos consumidores sergipanos ao Banco Bradesco. E a forma de demonstrar essa representatividade seria a comprovação da existência de associados da ASPAC residentes no Estado do Sergipe - já que o resultado da ação civil pública estaria limitado a tal Estado, por força da aplicação do artigo 16 da Lei da Ação Civil Pública (Lei n ${ }^{\circ}$ 7.347/1985). Contra essa decisão houve agravo da associação autora, para que se reconhecesse a desnecessidade de tal comprovação.

Conquanto não tenha havido decisão acerca da legitimidade da associação, mas simples determinação de comprovação da representatividade nos termos supracitados, o Tribunal, entendeu que a ASPAC era ilegítima para ajuizar a ação civil pública e fundamentou a decisão em diversos pontos da atuação e do estatuto da entidade, entre eles a generalidade dos objetivos institucionais da entidade. O acórdão, após discorrer sobre a possibilidade do controle ope judicis da representatividade adequada, pondera que a associação alterou seu estatuto para fazer constar que poderia defender em juízo praticamente todos os direitos transindividuais, e isso revelava sua inidoneidade para a defesa desses interesses. Por esse motivo, negou a atribuição de legitimidade à entidade, extinguindo a ação sem julgamento do mérito, por carência de ação ${ }^{581}$.

\footnotetext{
${ }^{580}$ Agravo de Instrumento ${ }^{\circ}$ 0880/2009, Primeira Câmara Cível do Tribunal de Justiça de Sergipe, Des. Rel Clara Leite de Resende, Julg. 22.03.2010.

581 "Nesse diapasão, seguindo a lição da doutrina acima referida, percebe-se que a decisão recorrida foi no sentido de cumprir a segunda fase da análise da legitimidade ad causam do autor da demanda coletiva. Vale dizer, percebe-se que o magistrado de piso, após observar a Lei 7.347/85, chegou à conclusão de que há previsão para que a associação em análise ingresse com demanda coletiva e buscou averiguar se no caso em concreto havia pertinência entre os objetivos da mencionada pessoa jurídica e os interesses que busca proteger com a ação efetivamente apresentada.

Na espécie, a agravante traz documento (fl. 87) que dá conta de alteração no Estatuto Social daquela pessoa jurídica, de modo a estabelecer como um de seus objetivos o seguinte:

A sociedade terá por objetivo específico a proteção ao consumidor, a ordem econômica, a livre concorrência, ao patrimônio artístico, estético, histórico, turístico e paisagístico, a orientação a assistência jurídica ao cidadão quanto ao exercício da cidadania, educação ambiental e sanitária, orientação e assistência na proteção e defesa dos direitos trabalhistas, com exceção a questões tributárias.

Percebe-se, pois que a previsão dos objetivos da associação recorrente é de tal forma genérica, que ela pretende se colocar, em âmbito jurídico, como pessoa apta a defender, pela via da Ação Civil Pública, praticamente todos os interesses coletivos.

A generalidade de objetivos da agravante revela, em verdade, sua inidoneidade à representação de todos os interesses mencionados em seu estatuto, porquanto não é admissível a criação de associação com o fim de proteger todo e qualquer interesse socialmente relevante.

Assim, conclui-se que a agravante é parte ilegítima para a propositura da presente demanda. [...]"
} 


\title{
7.2.3.2. O caso da Associação e Centro de Pesquisas Ecológicas de Ubarana (ACEPEUB)
}

A orientação se repete em julgado do Tribunal de Justiça do Estado de São Paulo, em que uma associação com amplíssimos objetivos institucionais, situada no município de Ubarana, pleiteia interesses ambientais referentes a fatos ocorridos em outro município. Nesse caso, a decisão do Tribunal de Justiça de São Paulo conta com trecho bastante interessante:

\begin{abstract}
A autora, constituída em 2003 por dez associados (fls. 67), com sede em Ubarana, tem por finalidade social "propor soluções para os problemas ambientais da região, formar convênios...realização de pesquisas e projetos...dentro da agenda $21 \ldots$ preservação da floresta...defesa, elevação e manutenção da qualidade de vida do ser humano e do meio ambiente...preservação da natureza na comunidade, no país e para o mundo...problemas ambientais do município e regiões...preservar a vida e o futuro da humanidade", etc. O estatuto foi alterado e se tornou ainda mais amplo e vago quanto aos objetivos sociais (fls. 74 e 82).

Trata-se, pois, de entidade que pretende assumir funções amplíssimas, sem limitação territorial, dispensando a existência de quaisquer outras, e que pode substituir o próprio Ministério Público, tal o espectro de atribuições que se deu a si própria, mais amplo do que o da aludida instituição. [...]

Ainda que se trate de entidade com objetivos nobres, não há como admitir que uma associação formada em um município por cidadãos locais possa agir na defesa do meio ambiente de outros municípios, sem relação com o que possa haver de comum entre esses associados ou a sociedade civil em geral. Associação de defesa do meio ambiente de município situado em Estado do Sul, por exemplo, não tem, em princípio, interesse e legitimidade para interferir em política pública de município de Estado do Norte do país, a pretexto de defender o meio ambiente local. Admitir esta possibilidade, ao invés de ampliar democraticamente o acesso à Justiça, o exercício da cidadania e a solidariedade social, acabaria por permitir a proliferação de associações de fachada voltadas realmente à busca de oportunidades de ganhos com honorários advocatícios ou ao oportunismo político camuflado de interesse público.

Neste sentido deve ser entendida a regra do artigo $5^{\circ}$, II da Lei n. 7347/85. Assim como deve "haver um vínculo de pertinência entre o objeto da ação e a função ou os fins norteadores da atividade e das competências do autor" (cf. Marçal Justen Filho, Curso de Direito Administrativo, Ed. Saraiva 2005, p. 787), também assim é imprescindível um vínculo entre os fins da associação autora e os interesses comuns de seus associados. Se nenhum deles tem individualmente nem mesmo interesse de fato em obter certo provimento jurisdicional, a associação por eles constituída tampouco terá. $[\ldots]^{582}$
\end{abstract}

Este último julgado, o julgador faz menção à atuação abusiva das associações que têm amplíssimas finalidades institucionais, mencionando a possibilidade de buscarem ganhos com honorários advocatícios ou, ainda, proporem ações com finalidades de defesa

\footnotetext{
${ }^{582}$ Agravo de Instrumento $\mathrm{n}^{\mathrm{o}}$ 0142109-23.2012.8.26.0000, $10^{\mathrm{a}}$ Câmara de Direito Público do Tribunal de Justiça de São Paulo, Des. Rel. Antonio Celso Aguilar Cortez, ACEPEUB - Associação de Estudos e Pesquisas Ecológicas da Unidade Brasileira x Sonda Supermercados Importação e Exportação LTDA, Julg. 15.10.2012.
} 
de interesses políticos camuflados - o que já indica que essa é uma preocupação de alguns magistrados. Trata-se de mais um caso em que a aferição da representatividade adequada se presta a coibir o abuso do direito de demandar.

Como narrado, a exigência legal da pertinência temática tem como finalidade garantir a qualificação da defesa dos direitos difusos, coletivos e individuais homogêneos em juízo, permitindo que entidades que efetivamente atuem - inclusive extrajudicialmente - na defesa desses temas promovam uma defesa judicial de qualidade dos interesses dos indivíduos ali representados ou substituídos.

Ao incluir entre suas finalidades institucionais inúmeros direitos - que muitas vezes sequer fazem parte de sua agenda de atuação -, as associações têm como objetivo a propositura de demandas coletivas sobre os mais diversos assuntos sem, no entanto, garantir uma defesa de qualidade dos direitos que se propuseram a resguardar. Nisso reside o desvio de finalidade que caracteriza o abuso de direito: associações que não tem qualquer experiência ou expertise em determinados direitos, que não atuam efetivamente em sua defesa, incluem-nos em seus estatutos com o objetivo de propor o maior número de demandas coletivas possível. Esse abuso de direito no âmbito material acaba por contaminar também o processo, sendo uma forma de abuso do direito de demandar, já que a legitimidade ativa é conferida apenas em razão da suposta finalidade que seria perseguida pela associação ${ }^{583}$.

Essa atuação abusiva das associações, embora possa parecer inofensiva em uma análise perfunctória, tem consequências nefastas para o sistema. A primeira delas se coaduna, justamente, com a qualidade da defesa dos direitos coletivos, já que a improcedência da demanda fará coisa julgada que atingirá toda uma coletividade, salvo se for julgada improcedente por falta de provas - e, mesmo nesse caso, a ação só poderá ser reproposta mediante a comprovação da existência de prova nova ${ }^{584}$. A segunda tem reflexos econômicos para o erário, já que, ao se autorizar que uma só entidade - com um sem número de finalidades institucionais, por vezes fictícias - ingresse com diversas demandas coletivas, deve-se contabilizar que todas elas movimentarão o poder judiciário valendo-se da isenção de custas garantida pela lei. Em vista disso, faz-se necessária a

\footnotetext{
${ }^{583}$ Cf. capítulo 6, subitem 6.1.2.

584 A disciplina da coisa julgada no processo coletivo está prevista nos artigos 16 da Lei da Ação Civil Pública (Art. 16. A sentença civil fará coisa julgada erga omnes, nos limites da competência territorial do órgão prolator, exceto se o pedido for julgado improcedente por insuficiência de provas, hipótese em que qualquer legitimado poderá intentar outra ação com idêntico fundamento, valendo-se de nova prova) e no artigo 103, I, II e III do Código de Defesa do Consumidor.
} 
análise da representatividade adequada - ainda que pela via da repressão ao abuso de direito - para preservar não apenas os jurisdicionados, mas o próprio sistema de defesa dos direitos transindividuais.

Atualmente, entretanto, na mesma esteira do que tem ocorrido quando se identifica o abuso da forma associativa, a jurisprudência tem se limitado a reconhecer a ilegitimidade ativa da associação sem aplicar a ela nenhuma das sanções previstas pelo ordenamento jurídico. Diante disso, é difícil pensar em uma mudança de mentalidade e em uma efetiva moralização da atuação das associações nos processos coletivos, especialmente em um cenário em que a possibilidade de aferição da representatividade adequada pelos juízes continua ausente no ordenamento jurídico pátrio.

\subsection{A ATUAÇÃo do MINISTÉRIO PÚBLICO COMO CUSTUS LEGIS E SUA INFLUÊNCIA NA AFERIÇÃO DA REPRESENTATIVIDADE ADEQUADA DAS ASSOCIAÇÕES: UMA ANÁLISE DE SUA ATUAÇÃO IN CONCRETO}

Conforme discutido no terceiro capítulo, e em diversos outros pontos deste presente estudo, o Ministério Público figura no rol de legitimados ativos para a propositura de ações de interesse da coletividade. Esse, entretanto, não é o único papel do parquet nas ações coletivas. O Código de Processo Civil (artigo 82, III), a Lei da Ação Civil Pública (artigo $5^{\circ}, \S 1^{\circ}$ ) e o Código de Defesa do Consumidor (artigo 92) estabelecem que, nas causas em que o Ministério Público não for autor, ele deverá atuar como fiscal da lei.

Essa tarefa atribuída ao órgão ministerial vem no bojo de uma mudança de perspectiva quanto ao que seria considerado interesse público. Em um primeiro momento tratava-se apenas do interesse do Estado - em geral na perspectiva do confronto com o interesse do indivíduo. Essa visão, no entanto, evoluiu para abarcar na definição de interesse público o interesse da sociedade de uma forma geral ${ }^{585}$. Daí se justifica o fato de que, nas ações que envolvem os direitos transindividuais - porquanto todas elas envolvam interesses da coletividade -, quando o parquet não estiver defendendo tais direitos, na qualidade de autor, deverá fiscalizar a atuação do legitimado ativo que ingressou com a demanda.

\footnotetext{
${ }^{585}$ Ver "A atuação do Ministério Público nas ações coletivas - o Ministério Público e a defesa dos interesses individuais homogêneos" (MAZZILLI, Hugo Nigro. In: GOZZOLI, Maria Clara; CIANCI, Mirna; CALMON, Petrônio e QUARTIERI, Rita (coord.). Em defesa de um novo sistema de processos coletivos estudos em homenagem a Ada Pellegrini Grinover. São Paulo: Saraiva, 2010, p. 255-256).
} 
O Código de Processo Civil, em seu artigo 83, ocupou-se de descrever como se dá a atuação do Ministério Público enquanto custus legis ou fiscal da lei. Deverá ser intimado de todos os atos do processo, tendo vista dos autos logo após as partes, podendo juntar documentos e produzir provas. E tanto a lei da Ação Civil Pública quanto o Código de Defesa do Consumidor reputam obrigatória a participação do parquet nesse papel em todas as ações coletivas. A importância atribuída ao papel do Ministério Público nesse tocante é tão grande que a não intimação para sua manifestação implicará nulidade de todo o processo $^{586}$.

Esclarece Ada Pellegrini Grinover que a atribuição dessa responsabilidade ao Ministério Público nos processos coletivos se deve, justamente, ao receio de que os demais legitimados não atuem com a diligência que deles se espera na defesa dos interesses da coletividade $^{587}$. A íntima ligação do Ministério Público com o poder estatal, sua atribuição constitucional para a defesa do interesse público em seu sentido mais amplo e, também, a reputação de que goza junto à sociedade lhe atribuiriam melhores condições para verificar a atuação dos demais legitimados e, eventualmente, assumir processos que não tenham sido conduzidos devidamente. Explicita a doutrinadora:

\footnotetext{
São conhecidos os riscos inerentes a toda e qualquer ação de natureza coletiva, sobretudo quando se escolhe o esquema de legitimação concorrente e disjuntiva: riscos de colusão entre os sujeitos do processo, de pressões descabidas do autor coletivo, de manobras visando arrancar vantagens indevidas em troca da desistência ou abandono da causa. Por isso o legislador tomou a cautela de exigir a presença do Ministério Público, quando não seja autor da ação, como fiscal da lei ${ }^{588}$.
}

De acordo com o trecho supracitado, se o escopo da atuação do Ministério Público como fiscal da lei se dá no sentido de que os direitos transindividuais serão resguardados mesmo na eventualidade de uma atuação inidônea, ilegal ou inepta do legitimado ativo que propuser a ação coletiva, não é demais dizer que o órgão ministerial deverá zelar pela

\footnotetext{
586 Artigo 84 do Código de Processo Civil. Quando a lei considerar obrigatória a intervenção do Ministério Público, a parte promover-lhe-á a intimação sob pena de nulidade do processo.

587 Segundo Ricardo Barros Leonel: "O que justifica a intervenção é o interesse público na defesa dos interesses superindividuais, i.e., a "natureza da lide", não a qualidade das partes. A atuação ministerial deverá ser protetiva daqueles interesses." (LEONEL, Ricardo de Barros. Manual do Processo Coletivo. 2.ed. São Paulo: RT, 2011, p. 192).

${ }^{588}$ GRINOVER, Ada Pellegrini (et. alli). Código Brasileiro de Defesa do Consumidor comentado pelos atores do anteprojeto...Op. cit., p. 142.
} 
adequada representação dos interesses da coletividade - reflexamente, terá ampla liberdade de se manifestar quanto à representatividade do autor da demanda ${ }^{589}$.

E essa atuação é facultada ao Ministério Público desde a citação do réu no processo coletivo, de modo que sua intervenção ativa - verificando a atuação do legitimado ativo se dará em todo o curso do processo e não poderá ser limitada aos casos em que o autor coletivo, em especial as associações, abandone a causa de forma infundada (artigo $5^{\circ}, \S^{\circ}$ da Lei $n^{\circ}$ 7.347/1985). Isso porque não faria sentido admitir que o órgão ministerial assumiria uma ação apenas depois que o próprio legitimado se prontificasse a dela desistir - a interpretação das funções de fiscal da lei do parquet, enquanto guardião do interesse da coletividade, deve alcançar a possibilidade de coibir a má conduta do colegitimado tão logo ela seja identificada.

O Ministério Público de São Paulo, particularmente em sua divisão de proteção ao consumidor, assumiu postura nesse sentido nos autos da ação civil pública movida pela Associação Nacional de Defesa da Cidadania e do Consumidor (ANADEC) contra o Banco HSBC Brasil S/A. A ANADEC propôs ação civil pública pretendendo a condenação da instituição financeira a se abster de cobrar a tarifa conhecida como "tarifa de cheque de alto valor" - para cheques emitidos em valores iguais ou superiores a R\$ 5.000,00 (cinco mil reais) -, pleiteando, ainda, a restituição dos valores cobrados a esse título a todos os consumidores ${ }^{590}$.

Instado a se manifestar, o integrante do parquet paulista se absteve de apreciar o mérito da controvérsia, limitando-se a apreciar as condições da ação coletiva. No que toca à legitimidade ativa da ANADEC, trouxe aos autos da referida ação civil pública um despacho prolatado por outro promotor de justiça em uma representação aberta no Ministério Público contra a referida associação. Essa representação foi iniciada pela Associação Brasileira de Consórcios (ABAC) solicitando que o órgão ministerial analisasse a conduta da ANADEC, destacando uma série de irregularidades que poderiam conduzir à dissolução da entidade.

O integrante do parquet paulista, ao despachar a representação, observou diversas condutas inidôneas e abusivas por parte da ANADEC - que figura como autora em uma

\footnotetext{
${ }^{589}$ Mais uma vez, sobre o tema, esclarece Ricardo Barros Leonel que a atuação do Ministério Público como fiscal da lei somente se pauta pela proteção ao interesse público - deverá agir em prol desse interesse -, mas não está obrigado a opinar pela procedência da ação se verificar que foi proposta sem fundamento ou que se trata de ação temerária. LEONEL, Ricardo Barros. Manual do Processo Coletivo.... Op cit., p. 192-193.

${ }^{590}$ Processo n ${ }^{\circ}$ 583.00.2007.126914-1, que correu na $29^{\text {a }}$ Vara Cível da Comarca de São Paulo, e foi julgada (a ação) improcedente, tendo a sentença sido confirmada pelo Tribunal de Justiça de São Paulo e transitado em julgado em agosto de 2011.
} 
série de ações civis públicas. Na cota ministerial foram destacadas as práticas abusivas, contrárias à boa-fé e completamente alheias ao objetivo maior do processo coletivo, perpetradas pela associação em questão.

De início, o Ministério Público destaca o desvio da forma associativa e o desvio de finalidade da ANADEC, que, de acordo com as evidências, seria um escritório de advocacia travestido de associação. Pontua, para demonstrar essa afirmação, que a associação foi criada por dois advogados, uma contadora e uma secretária, ressaltando que, em todas as ações civis públicas propostas pela entidade, o escritório de advocacia Fratti e Branco Advogados Associados (do qual são únicos sócios o presidente e o vice-presidente da própria ANADEC) a representava. Além de compartilharem o quadro diretivo, tanto a associação quanto a sociedade de advogados compartilham, também, o mesmo endereço $^{591}$.

A associação se ocupou de especificar em seu estatuto que ao menos dois integrantes da diretoria da associação seriam advogados e, ainda, o percentual de retenção a ser aplicado, caso obtivesse condenação em dinheiro na justiça que beneficiasse seus associados. A diretoria da associação buscou garantir, ainda, que a vantagem econômica resultante das ações propostas fosse gozada pelos integrantes do quadro diretivo da entidade. É o que observa o promotor de justiça ao assinalar que, em alteração dos estatutos sociais, a ANADEC passou a permitir que os valores recebidos pela entidade em sua atuação extrajudicial e judicial passassem a poder ser distribuídos entre os integrantes - o que equivale dizer que o estatuto da associação não apenas assumia a existência de uma finalidade lucrativa como permitia a distribuição de honorários advocatícios dentro de sua estrutura $^{592}$.

\footnotetext{
591 "Pode-se dizer, ao menos numa primeira análise, da existência de indícios das alegadas irregularidades. Com efeito, vê-se da documentação instrutória da representação que a dita associação ANADEC foi criada em 1999 por dois advogados (Daniel José Ribas Branco e Ronni Fratti), uma contadora e uma secretária, estrutura característica de escritório de advocacia.

Na promoção de ações civis públicas, a ANADEC é representada processualmente pelo escritório de advocacia FRATTI E BRANCO ADVOGADOS ASSOCIADOS, dos advogados Daniel José Ribas Branco e Ronni Fratti, respectivamente presidente e vice-presidente da ANADEC.

O endereço da ANADEC (Rua Pereira Barreto, 63, Campinas) é exatamente o mesmo do escritório de advocacia FRATTI E BRANCO ADVOGADOS ASSOCIADOS."

592 "Em alteração dos seus estatutos, promovida em 2001, à disposição que vedava a distribuição de lucros, bonificações e vantagens (artigo 41), a ANADEC acresceu a "exceção" para valores recebidos pela entidade de origem extrajudicial e judicial. Parece de fácil apreensão, aqui, que a única receita que pode ter origem judicial é a verba honorária fixada em ações onde a associação for parte não sucumbente. Noutros termos, a alteração estatutária passou a permitir a distribuição de honorária advocatícia.

De outra parte, no estatuto da ANADEC se cuidou de estabelecer que, dos quatro integrantes da diretoria, dois necessariamente têm que ser advogados.
} 
Essas aparentes coincidências dão nota de que as duas pessoas jurídicas associação e escritório de advocacia - são, na verdade, uma só. Cada qual atuando no momento e da forma que lhe é mais vantajosa. Quando se trata de ingressar com ação civil pública, com a perspectiva de auferir honorários e sem estar exposto ao risco de pagar custas e honorários em caso de improcedência, usa-se a ANADEC. E pelo número de ações intentadas pela associação em questão, só no foro central da comarca de São Paulo (aproximadamente 358 em Julho de 2006), é de se notar que essa estratégia vinha sendo usada com muita frequência e, pode-se projetar, com algum nível de sucesso ${ }^{593}$.

Em seu despacho, o integrante do parquet paulista destaca detalhes da estrutura da associação que, conquanto não atentem diretamente contra a letra da lei, deixam entrever características de sociedade - tais como a possibilidade de distribuição de lucros advindos de honorários advocatícios e o estabelecimento de qualidades específicas para os integrantes da diretoria (a qualidade de advogado). Essas são características marcantes de sociedades de advogado e não de associação, pelo que não importa o nome que constou no estatuto, mas a maneira como a entidade atua na prática ${ }^{594}$.

Outro ponto destacado pelo Ministério Público foi a postura da entidade ANADEC ao ser instada a apresentar um rol de seus associados, visando demonstrar que se trata

Observa-se ainda que, da ficha de inscrição à ANADEC, [...] consta autorização do associado no sentido de que "nas ações que visem também uma condenação em dinheiro a ser paga pela empresa-ré, a título de indenização, que a Associação repasse ao profissional contratado, o percentual equivalente a 9\% do valor total da indenização a que teria direito, na qualidade de associado da ANADEC, em razão dos trabalhos jurídicos efetuados em meu interesse"(fls. 33).

Dado que o "profissional contratado" a que se refere a cláusula não é senão o escritório de advocacia FRATTI E BRANCO ADVOGADOS ASSOCIADOS, de titularidade do presidente e do vice-presidente da ANADEC, difícil não vislumbrar identidade com conteúdo típico de contrato de honorários."

593 "E realmente a militância no Foro Central desta Capital tem permitido observar que a ANADEC tem mesmo aforado centenas de ações civis públicas, jamais formando litisconsórcio passivo, conquanto se cuidasse exatamente da mesma tese de direito, incidente sobre idêntica situação de fato, tudo deduzido inclusive em petições iniciais padronizadas. $\mathrm{O}$ valor das causas, de regra, é atribuído nas petições iniciais em patamares notavelmente exagerados, quase invariavelmente ensejando procedentes impugnações por parte dos réus." O promotor, para fazer tal afirmação de que a entidade ingressa com diversas ações, se calca em sentença de extinção sem julgamento do mérito, por reconhecimento da ilegitimidade ativa da associação autora, prolatada nos autos do processo $\mathrm{n}^{\circ}$ 583.00.2006.135211-4 promovido pela ANADEC contra a CNF Consórcio Nacional, da qual se destaca o seguinte trecho: "E vêm à luz as indagações feitas pela ré em sua defesa: o objetivo ser a defesa do consumidor ou, como associação formada por advogados, procurar demandas coletivas, sem pagamento de qualquer custa ou despesa pela isenção do art. 87, Código de Defesa do Consumidor, para a honorária advocatícia em caso de sucesso da demanda, e sem o risco do insucesso? Essa indagação é pertinente, até pelas centenas de ações coletivas vistas nesse Fórum Cível Central ajuizadas pela mesma e ora autora, às vezes contra o mesmo réu, mas separadas para diferentes pedidos, com a possibilidade de somatória de honorárias, ou se todos pedidos reunidos em uma só ação, e com procedência parcial, perde-se a honorária pela sucumbência recíproca. Esse é um panorama real. Em pesquisa feita em 25/08/2006, são trezentos e cinquenta e oito (358) registros de ações distribuídas pela autora.”

${ }^{594}$ Cf. Capítulo 3, subitem 3.4. 
efetivamente de uma associação que atua na defesa dos interesses do consumidor. Conforme analisado anteriormente, a solicitação da lista de associados - conquanto seja pacificado na jurisprudência que não pode ser requisito para a atribuição da legitimidade ativa - tem sido medida utilizada por juízes e tribunais, em casos de suspeita de desvio de finalidade da entidade associativa ${ }^{595}$. O intuito é verificar se a associação efetivamente representa os interesses de alguém, pelo que se trata nitidamente de uma forma de aferir a representatividade da entidade. E foi exatamente o caso narrado pelo parquet na cota ora analisada em que, instada a apresentar lista de associados, a ANADEC trouxe rol com a maioria dos indivíduos inscritos após a determinação judicial ${ }^{596}$.

O representante do Ministério Público conclui sua análise com a observação de que a associação em questão estaria "indevidamente se prevalecendo da isenção de custas de que cuida o artigo 87 do CDC, com correlato e manifesto prejuízo ao erário" e, por outro ângulo, "os responsáveis pela ANADEC estariam se prevalecendo de personalidade jurídica da associação para enriquecimento pessoal, incorrendo em claro desvio de finalidade, contrário à ordem pública e à moral". Partindo dessas conclusões, opinou pela dissolução da associação.

Esse despacho, da lavra da Promotoria de Justiça do Consumidor de São Paulo, foi acostado posteriormente pelo próprio Ministério Público em outras ações civis públicas movidas pela mesma associação de defesa do consumidor, alertando para atos de desvio de finalidade da referida entidade - uma delas, a reportada nessa pesquisa, movida pela ANADEC contra o Banco HSBC. Essa ação, especificamente, foi extinta com resolução do mérito, de modo que o alerta do Ministério Público não se prestou a fundamentar o reconhecimento da ilegitimidade ativa. Não há notícia, no entanto, de ajuizamento do processo de dissolução da entidade pela promotoria de justiça de Campinas - que seria competente para tanto, por ser a comarca em que a associação tem sua sede.

\footnotetext{
${ }^{595}$ No Capítulo 3 deste estudo discutiu-se que no ordenamento jurídico brasileiro não existe nenhuma exigência legal específica de número de associados para compor determinada associação. Ao menos em tese, o requisito da união de pessoas, marca característica de uma associação, estaria satisfeito se dois indivíduos se juntassem com um objetivo não econômico comum (subitem 3.1.1). A medida de solicitar listas de associados é um dos elementos que pode ser analisado pelo juiz na verificação da idoneidade da associação, além da forma como atua - inclusive extrajudicialmente - e se efetivamente protege os interesses de alguém. Todos estes são caracteres que ajudarão a compor o quadro da representatividade adequada.

596 "De outra parte, por informação verbal do $1^{\circ}$ Promotor de Justiça do Consumidor da Capital, veio a meu conhecimento que, em autor de ação civil pública promovida pela ANADEC, depois de questionada sua legitimidade ativa justamente em virtude de possível descaracterização como associação voltada para defesa de interesses sociais, o Juízo da causa determinou a apresentação da relação de seus associados. Passado algum tempo, em cumprimento da determinação judicial, a ANADEC apresentou lista de associados, dos quais substancial parte fora admitida, coincidência ou não, depois de prolatado o aludido despacho judicial".
} 
As condutas praticadas por essa entidade, no sentido de se autodenominar associação, mas se estruturar e atuar de forma análoga à sociedade de advogados são exemplos claros do desvio de finalidade. Esse desvio de finalidade tem claro impacto na atribuição de legitimidade para a associação na propositura de ações coletivas - se não pelo fato de que, a rigor, não pode ser considerada uma associação, pelo fato de estar atuando em flagrante abuso do direito de demandar conferido às associações ${ }^{597}$.

Ademais, essas atitudes têm impacto inequívoco na representatividade adequada. Isso porque, conforme observado tanto na cota do Ministério Público quanto na sentença citada pelo integrante do parquet corroborando sua opinião, o objetivo principal da associação passa a ser criação de mecanismos para angariar honorários sucumbenciais propondo um grande número de ações, sem litisconsórcio passivo, desmembrando pedidos contra um mesmo réu - e não a efetiva e vigorosa defesa dos interesses do consumidor. Até porque, imagina-se, quanto mais ações concomitantes propostas, maior será o trabalho da associação e menor o seu foco e empenho em cada uma delas.

Assim sendo, em virtude das condutas relatadas pelo Ministério Público no caso supracitado, parece certo que os integrantes da associação não se perfazem em representantes adequados da coletividade em juízo, por parecerem mais preocupados com os lucros que se poderiam auferir nas demandas do que com a efetiva defesa dos interesses transindividuais.

Os exemplos aqui citados de controle da representatividade adequada pelos juízes e pelos membros do Ministério Público - no papel de custus legis - ainda são poucos e esparsos na jurisprudência brasileira. Não foi a intenção deste estudo trazer números que permitissem afirmar uma tendência dos tribunais brasileiros, mas, como anteriormente esclarecido, teve-se como objetivo buscar exemplos de casos em que foi realizado o controle da representatividade adequada e de que forma isso ocorreu.

Alguns dos acórdãos pesquisados ilustraram as premissas teóricas desenvolvidas nos capítulos anteriores, sendo possível concluir que os juízes realizam o controle da representatividade adequada das associações em determinadas situações, conquanto nem sempre utilizem essa denominação ou os parâmetros classicamente estabelecidos pela doutrina para fazê-lo. Importa observar, no entanto, que esse controle tem se mostrado eficaz para barrar o acesso ao judiciário de associações - ou entidades que assim se autodenominam - nitidamente inidôneas ou carentes de seriedade, cuja atuação tem

${ }^{597}$ Cf. Capítulo 6, subitem 6.1.2. 
potencial altamente danoso tanto para a coletividade quanto para o microssistema de processos coletivos. 


\section{CONCLUSÃO}

À guisa de conclusão, destaca-se que a pesquisa desenvolvida ao longo dessa dissertação teve como objetivo principal analisar os limites da atuação jurisdicional no processo coletivo, especialmente no que toca à atribuição da legitimidade ativa às associações, verificando se - e de que forma - os tribunais poderiam realizar um escrutínio acerca da real representatividade dessas entidades em relação aos direitos transindividuais.

Conforme destacado em diversos pontos desse estudo, tal análise se mostra particularmente importante, uma vez que a tomada de consciência dos indivíduos, quanto à sua condição de integrantes de uma realidade social em que as relações - jurídicas ou não acontecem de forma cada vez mais rápida, massificada e interdependente, determinou o fortalecimento do que se convencionou chamar de microssistema de tutela dos interesses coletivos.

Paralelamente, e dentro desse mesmo contexto, observou-se uma crescente importância atribuída à sociedade civil organizada, como centro de agregação e veículo das pretensões de um grande número de pessoas, o que acabou por impactar em um aumento do número de associações, com os mais diversos objetivos institucionais.

Esses dois fenômenos são extremamente positivos, seja do ponto de vista jurídico, social ou econômico, visto que, pela primeira vez na história, se está possibilitando à sociedade participar diretamente da defesa dos direitos de seus integrantes, através de um sistema de regras especialmente arquitetado para levar a juízo os interesses da coletividade - proporcionando um melhor, mais rápido e mais racional acesso à justiça ${ }^{598}$. Para viabilizar a tutela dos interesses coletivos, os estudiosos do tema se ocuparam de criar um arcabouço legislativo próprio que, conquanto baseado nos institutos do direito processual civil clássico, teve de ser redesenhado para albergar a tutela dos direitos transindividuais.

E o instituto do processo civil clássico que teve de ser adaptado de forma mais profunda foi justamente a legitimidade ad causam, particularmente, a legitimidade ativa. Isso porque o intuito dos processos coletivos sempre foi veicular as pretensões de um grande número de indivíduos - sejam eles passíveis de identificação ou não ${ }^{599}$ - sem que fosse necessário que todos os titulares dos direitos comparecessem em juízo. Em outras

\footnotetext{
${ }^{598}$ PASCHOAL, Maximilian Fierro. A representatividade adequada na ação coletiva brasileira (lei da ação civil pública e código de defesa do consumidor)...Op. cit., p. 307.

${ }^{599}$ Nos moldes discutidos no capítulo 2, subitem 2.2.1 deste estudo, quanto à caracterização dos interesses metaindividuais como difusos, coletivos e individuais homogêneos.
} 
palavras, se o titular do direito material não irá a juízo defender seus próprios interesses, quem poderá fazê-lo? Essa primeira pergunta foi respondida com a ampliação da legitimidade ativa para permitir que, mediante autorização legal, alguém, que não o titular do direito, fosse a juízo para, em nome próprio, tutelar direito alheio. Com isso, o legislador escolheu um rol de legitimados para a propositura de ações coletivas, contemplando desde entidades ligadas ao poder do Estado - como o Ministério Público e a Defensoria Pública - até as associações civis.

Estas últimas foram o objeto central de análise nesse estudo, justamente por terem nascido espontaneamente no seio da sociedade sem a interferência do Estado, um retrato fiel da atuação dos indivíduos organizados na defesa de determinados ideais, em juízo e fora dele. Além da atribuição de legitimidade às associações para defender os direitos de seus associados - em um sistema de substituição processual -, a lei conferiu a essas entidades poderes para representar a sociedade como um todo, dentro de seus objetivos institucionais, erigindo-as ao patamar de autoras ideológicas.

Se em um primeiro momento surgiu a preocupação acerca de quem seria o legitimado para defender os direitos dos integrantes da coletividade - que não integrariam o polo ativo do processo pessoalmente -, em um outro momento a escolha dos legitimados fez surgir um novo questionamento: como garantir que o autor coletivo representará os interesses dos ausentes com o mesmo vigor, capacidade técnica e idoneidade que os próprios titulares do direito material o fariam? Apenas garantindo que a defesa do legitimado extraordinário será tão boa quanto aquela intentada pelo próprio interessado, é que será possível assegurar a consecução da garantia constitucional do devido processo legal nos processos coletivos.

É na resposta a essa indagação que se insere o estudo da representatividade adequada, conceito que nasceu junto com o ideário dos processos coletivos, na Inglaterra medieval, em que eram conhecidos como ações representativas. Desde a gênese das ações que pretendiam tutelar direitos da coletividade, assumiu-se que somente a presença no polo ativo da demanda de representante, capaz de defender os interesses de todos os ausentes de forma adequada, asseguraria a realização da garantia do devido processo legal. Com isso, a sentença prolatada poderia vincular e produzir efeitos nas esferas jurídicas de todo o grupo representado. Esse conceito, nascido no direito inglês, como se viu, tomou corpo em outro ordenamento de Common law, nos Estados Unidos da América, onde as ações coletivas são usadas como instrumento ímpar de veiculação das pretensões da coletividade. 
É cediço que as Class Actions norte-americanas são consideradas um exemplo de sucesso na tutela dos direitos coletivos, tendo a legislação desse país influenciado diretamente na positivação de regras de processo coletivo em ordenamentos jurídicos ao redor do mundo - inclusive no Brasil. E a aferição do requisito da representatividade adequada pelo juiz que recebe a Class Action é medida indispensável para que a demanda possa ser recebida e que prossiga como ação coletiva. Em outras palavras, não há ação coletiva se não for demonstrada e comprovada - em todas as fases do processo - a adequação do representante. Por ser um requisito que se apura, eminentemente, no caso concreto, foi a jurisprudência americana que desenvolveu com maior grau de precisão quais seriam as características de um representante adequado. Estas podem ser resumidas, entre outras, na capacidade técnica, idoneidade e vigor do representante na defesa dos interesses da coletividade ${ }^{600}$.

Muito embora a legislação brasileira referente ao tema tenha sido influenciada em grande medida pelas Class Actions norte-americanas, optou o legislador por não positivar expressamente a necessidade de se aferir a representatividade adequada, o que levou parte da doutrina a considerar que todos os legitimados arrolados em lei são presumivelmente representantes adequados dos direitos transindividuais em juízo.

Ao longo deste estudo, demonstrar demonstrou-se que essa presunção não pode existir, nem em relação aos legitimados ativos ligados ao poder do Estado e, menos ainda, para beneficiar as associações civis. Tal raciocínio vai contra a lógica na qual uma associação não seria capaz de defender os interesses em todas as oportunidades, uma vez que é impossível assumir previamente que determinada entidade associativa pode defender adequadamente todos os interesses transindividuais, em todos os casos concretos.

Como se viu, os requisitos estabelecidos pelo legislador para a atribuição de legitimidade ativa às associações - a pré-constituição há um ano e a inclusão em seus objetivos institucionais dos direitos que pretendem defender - podem se prestar a coibir os casos mais flagrantes de falta de representatividade adequada, em que uma determinada associação busca atuar em juízo na defesa de direito completamente alheio a sua finalidade institucional. Esses requisitos, no entanto, não podem ser confundidos com a representatividade adequada nem tampouco limitar a atividade do legislador, uma vez que

\footnotetext{
${ }^{600}$ MULLENIX, Linda. Taking adequacy seriously: the inadequate assessment of adequacy in litigation and settlement classes...Op. cit., p. 1704 e 1705.
} 
a verificação destes nos moldes da lei - mediante a leitura dos estatutos - não se afigura apta a afastar os casos mais elaborados de abuso perpetrado pelas associações.

Esses abusos do direito de demandar só poderão ser afastados mediante uma atuação efetiva dos magistrados no caso concreto, e esse estudo procurou demonstrar que a aferição da representatividade adequada é a forma mais eficiente de fazer esse controle, podendo ser realizada pelos juízes mesmo à míngua de previsão legal específica - uma vez que se encontra dentro dos papéis atribuídos hodiernamente aos magistrados integrar eventuais lacunas na lei com o objetivo de atingir os fins colimados pelo ordenamento jurídico como um todo. Nesse caso, a finalidade seria o efetivo cumprimento da garantia do devido processo legal no âmbito do processo coletivo.

A aferição da representatividade adequada é, pois, uma exigência constitucional. Não existe outra forma de assegurar o devido processo legal dentro do microssistema dos processos coletivos senão pela via do controle da adequação do representante - verificando se determinado legitimado está agindo no caso concreto com a diligência, o vigor e a capacidade com que atuaria o próprio titular do direito material. Apenas nessas circunstâncias se poderá dizer que foi respeitado o contraditório e assegurada a ampla defesa das partes, de modo que a sentença prolatada ao final da demanda possa atingir as esferas jurídicas daqueles que não participaram diretamente do processo. Apenas a verificação da representatividade adequada conferirá à sentença coletiva caráter vinculante a todo grupo representado pelos legitimados ativos.

Ademais, por meio da aferição da representatividade adequada, o juiz teria a possibilidade de afastar as associações que agem em claro abuso de direito, seja porque abusam da forma associativa - se declarando associações, mas agindo, na prática, como sociedades - com o objetivo não de defender os direitos transindividuais, mas intentando se valer das benesses legais para captar clientela e auferir receitas advindas de honorários advocatícios; seja porque incluem um sem número de finalidades institucionais em seus estatutos para poder propor o maior número de ações possíveis, com a mesma finalidade: auferir lucros. Via de consequência, negar ao juiz a possibilidade de verificar a idoneidade das associações - i.e. sua representatividade adequada -, equivaleria dizer que o magistrado não pode controlar comportamentos abusivos nem impedir que tais entidades ingressem em juízo para satisfazer objetivos egoísticos se beneficiando indevidamente de uma legislação que pretendia resguardar os interesses da sociedade como um todo. 
Por esse motivo, procurou-se trazer algumas ideias dos parâmetros que podem ser adotados pelos magistrados para realizar o controle da representatividade adequada, sem que seja necessário recorrer a alternativas de lege ferenda, somente se valendo do que hoje já se encontra positivado em nosso ordenamento jurídico. Concluiu-se que é possível fazer essa verificação por meio da análise pormenorizada dos estatutos das associações, conferindo se eles estão adequados aos ditames do Código Civil - conforme explicitado no capítulo 3 -, já que apenas em caso afirmativo existirá associação constituída nos termos da lei e, portanto, apta a ser titular de legitimidade ativa para a propositura de ação coletiva. Além disso, a associação só poderá ser considerada como tal se agir de acordo com o que se espera de uma entidade associativa - particularmente no que concerne à persecução de objetivos não econômicos.

Outra forma de se realizar o controle da representatividade adequada passa por uma efetiva interpretação dos estatutos das associações e de suas finalidades institucionais, confrontada com o objetivo da lei quando exigiu que as entidades associativas descrevessem em seus atos constitutivos os direitos que pretendem defender. Pretendeu-se garantir que as associações se dedicassem à defesa de uma determinada gama de interesses e direitos, geralmente correlatos, para que pudessem fazê-lo com algum grau de especialização e, consequentemente, de qualidade. Não se pode admitir, portanto, que uma associação que arrole entre suas finalidades institucionais todos os direitos difusos, coletivos e individuais homogêneos seja legítima e tenha representatividade suficiente para sua defesa. Isso porque quem se propõe a defender todos os direitos, muito provavelmente, não defenderá nenhum deles com a qualidade e o afinco necessários.

Viu-se, portanto, que a legislação vigente já dispõe de meios para que os juízes realizem a aferição da representatividade adequada das associações, bastando que, conforme proposto no curso de todo o estudo, se abandone a interpretação literal da lei para adoção de uma interpretação sistêmica. E isso se fez notar de forma mais clara quando da análise de julgados prolatados por diversos tribunais brasileiros, em que os desembargadores se valeram desses parâmetros para negar a legitimidade às associações a quem faltava representatividade adequada - notadamente porque, na maioria dos casos, perquiriam finalidade lucrativa por meio da propositura de diversas ações coletivas com a falsa pretensão de defender interesses da coletividade. Até mesmo os integrantes do Ministério Público, atuando como custus legis nas ações coletivas, identificaram condutas 
abusivas das associações autoras e reportaram ao juiz, requerendo verdadeiro controle da representatividade adequada e auxiliando o juiz na sua realização.

Assim, conclui-se que o controle jurisdicional da representatividade adequada das associações na propositura de ações coletivas não apenas é possível, como também recomendável, em nossa realidade atual, mesmo que inexista previsão legal. Como repisado em várias oportunidades, dizer o contrário implica em aceitar que a coletividade esteja à mercê de entidades sem credibilidade, inidôneas e despreparadas, o que conflita com os próprios objetivos da tutela coletiva, a qual se presta a beneficiar o maior número de pessoas possível, de forma mais eficiente e econômica. E, como se viu, já existem parâmetros legais para que essa aferição seja realizada.

No entanto, até para que se crie uma cultura favorável à essa prática, é altamente recomendável que o instituto da representatividade adequada seja positivado no ordenamento jurídico brasileiro. A previsão expressa de que o juiz deverá fazer o indigitado controle, bem como a fixação de alguns parâmetros para tanto - tal como já se chegou a propor nos anteprojetos do Código Brasileiro de Processos Coletivos e do Código Modelo de Processos Coletivos para a Ibero-América -, auxiliará os magistrados na realização dessa tarefa que, do ponto de vista desse trabalho, é indispensável para a manutenção do microssistema da tutela dos interesses transindividuais no país, e, também, para assegurar a proteção dos indivíduos que tem seus direitos tutelados pela via coletiva.

As normas positivadas atualmente no ordenamento jurídico brasileiro com a finalidade de assegurar a incolumidade dos direitos individuais no caso de improcedência de uma ação coletiva não são suficientes para descartar a necessidade da aferição da representatividade adequada do autor. Isso se dá porque, conforme analisado, a sentença de improcedência em ações discutindo direitos difusos e coletivos (artigo 81, incisos I e II do Código de Defesa do Consumidor) fará, respectivamente, coisa julgada erga omnes ou extensível a todos os integrantes da classe. Tal ação só poderá ser proposta novamente se o fundamento da decisão pela improcedência for ausência de prova e, ainda, se houver prova nova. Essa previsão, portanto, não afasta a hipótese da atuação desidiosa do legitimado ativo, que seria afastada pela aferição da representatividade adequada. Mesmo no caso de ações veiculando direitos individuais homogêneos (artigo 81, III do Código de Defesa do Consumidor) em que a coisa julgada só se forma para beneficiar os titulares do direito, uma representação deficiente e que implicasse a prolação de sentença de improcedência tem o condão de prejudicar sobremaneira tanto o direto individual - por meio da criação de 
um precedente negativo - quanto o sistema como um todo - ao desencadear a propositura de um grande número de ações individuais para pleitear o mesmo direito que poderia ter sido tutelado pela via coletiva, prejudicada por um representante inadequado. Mencionemse, ainda, os casos em que os direitos individuais são considerados de tão baixa magnitude que a logística do processo individual não faz sentido para leva-los a juízo.

Tampouco a previsão de que o Ministério Público assumirá as ações coletivas em caso de desistência ou abandono pelo autor original ( $\operatorname{artigo} 5^{\circ}$; $\$ 3^{\circ}$ da Lei $n^{\circ} 7.347 / 1985$ ) se prestaria a fundamentar a posição daqueles que pugnam pela impossibilidade de aferição da representatividade adequada. Até porque o texto do artigo é claro ao limitar a ação do Ministério Público aos casos em que o autor tenha abandonado ou desistido da causa, não se aplicando à hipótese de atuação desidiosa e/ou inidônea por parte do colegitimado que propôs a demanda.

Por esse motivo, acredita-se a aferição ope judicis da representatividade adequada das associações traria benefícios palpáveis a todos: aos indivíduos, vez que se estaria reforçando o sistema de proteção aos direitos tutelados pela via coletiva; ao Estado, que hoje arca com os custos de demandas coletivas propostas por autores que não estão verdadeiramente empenhados na defesa dos interesses transindividuais; e ao microssistema dos processos coletivos em si, já que o instituto que aqui se estudou se presta a assegurar que os direitos veiculados nas ações coletivas serão bem defendidos e conduzirão a uma decisão justa e capaz de pacificar uma controvérsia envolvendo um grande número de pessoas.

Por fim, tomando como base tudo o quanto se desenvolveu nas páginas anteriores, o presente estudo procurou demonstrar que o afã por garantir um amplo e irrestrito acesso à justiça não pode esbarrar no resguardo aos corolários do processo justo e équo, que passa necessariamente pela garantia do devido processo legal e da segurança jurídica, pelo respeito à boa-fé que deve permear todas as relações jurídicas, e, em última análise, pela conservação da dignidade da Justiça. $\mathrm{O}$ acesso à justiça no processo coletivo deve ser garantido, sim, mas apenas àqueles que pretendem agir de forma idônea, firme, capacitada e altruística na defesa dos interesses da coletividade. E a aferição da representatividade adequada das associações se presta a possibilitar esse escrutínio, para que o processo coletivo seja efetivamente um instrumento em prol da justiça e não em prol de interesses escusos de quem pretende desvirtuá-lo em benefício próprio. 


\section{BIBLIOGRAFIA}

ABDO, Helena Najjar. O abuso do processo. São Paulo: RT, 2007.

ARANTES, Rogério Bastos. Ministério Público e Política no Brasil. São Paulo: Ed. Sumaré, 2002.

ARAÚJO CINTRA, Antonio Carlos; GRINOVER, Ada Pellegrini; DINAMARCO, Cândido Rangel. Teoria Geral do Processo. 18ªed., São Paulo: Malheiros, 2002.

ARMELIN, Donaldo. Legitimidade para agir no direito processual civil brasileiro. São Paulo: RT, 1979.

ARRUDA ALVIM, José Manoel de. Ação Civil Pública - sua evoluçõa normativa significou crescimento em prol da proteção às situações coletivas. In: Édis Milaré (coord.). A ação civil púlbica após 20 anos: efetividade e desafios, São Paulo: RT, 2005, p. 73-84.

Perspectivas de alterações do sistema coletivo de ações no Brasil. Revista Forense, v. 399, Rio de Janeiro:2008, p. 27-34.

ASCARELLI, Tullio. Problemas das sociedades anônimas e direito comparado. São Paulo: Bookseller, 2001.

Societá, associazioni, consorzi, cooperative e transformazione.

Revista Del Diritto Commercialle, Milano, n. II, 1949.

ASCENÇÃO, José de Oliveira. Direito Civil: Teoria Geral. vol1. 3. ed. São Paulo: Saraiva, 2010.

1968.

A tipicidade dos direitos reais. Lisboa: Livraria Petroni,

BANDEIRA DE MELLO, Celso Antonio. Curso de Direito Administrativo.17.ed. São Paulo: Malheiros, 2004.

BARBOSA MOREIRA, José Carlos. Sobre pressupostos processuais. In Temas de direito processual civil. $4^{a}$ série. São Paulo: Saraiva, 1989.

difusos. Revista de Processo, São Paulo, ano X, n.39, jul/set 1985.

Tutela jurisdicional dos interesses coletivos ou A legitimidade para a defesa dos interesses difusos no direito brasileiro. In: Temas de Direito Processual. $3^{\text {a }}$ Série. São Paulo: Saraiva, 1984.

Dimensiones Sociales del Processo Civil. In Temas

de Direito Processual Civil, 4ª Série, Saraiva: São Paulo, 1989. 
Apontamentos para um estudo sistemático da

legitimação extraordinária. Revista dos Tribunais, São Paulo: RT, nº 404, 1969.

BASILE, Massimo. Le persone giuridiche. Milano: Giuffré, 2003.

BEDAQUE, José Roberto dos Santos. Pressupostos processuais e condições da ação, Justitia, 56 (156), out/dez 1991, p. 36-56.

BEDAQUE, José Roberto dos Santos. Direito e Processo, a influência do direito material sobre o processo.5.ed. São Paulo: Malheiros, 2009.

São Paulo: Malheiros, 2006.

Efetividade do processo e técnica processual.

BERMEJO, Patricia. Algunas reflexiones sobre la aplicación de Anteproyecto de Código Modelo de Procesos Colectivos para Iberoamérica en la República Argentina. In: GIDI, Antonio; MAC-GREGOR, Eduardo Ferrer. La tutela de los derechos difusos, colectivos e individuales homogéneos: hácia un codigo modelo para Iberoamérica. México: Porrúa, 2003.

BERNARDES DE MELLO, Marcos. Teoria do fato jurídico: plano da eficácia. 2.ed. São Paulo: Saraiva, 2004.

12.ed. São Paulo: Saraiva, 2002.

Teoria do Fato Jurídico: plano da existência.

BIANCA, Cesare Massimo. Diritto Civile. Vol. I. 2. ed. Milano: Giuffrè, 2002.

BUENO, Cassio Scarpinella. As class actions norte-americanas e as ações coletivas brasileiras: pontos para uma reflexão conjunta. Revista de Processo, São Paulo,v.21, n.82, p. 92-151, abr/jun.1996.

BUENO, José Antonio Pimenta. Direito Público brasileiro e análise da constituição do império. Rio De Janeiro: Ministério da Justiça e Negócios Interiores, Serviço de Documentação, 1958.

BUZAID, Alfredo. Agravo de petição no sistema do Código de Processo Civil. 2. ed. São Paulo: Saraiva, 1956.

CANOTILHO, José Joaquim Gomes. Civilização do Direito Constitucional ou constitucionalização do Direito Civil - a eficácia dos direitos fundamentais na ordem jurídico-civil no contexto do direito pós-moderno. In: GRAU, Eros Roberto; GUERRA FILHO, Willis Santiago (orgs). Direito constitucional - estudos em homenagem a Paulo Bonavides. São Paulo: Malheiros, 2000.

CAPPELlETTI, Mauro. O acesso dos consumidores à justiça. Revista de Processo, São Paulo: RT, 62/208, 1991. 
Formações sociais e interesses coletivos diante da justiça civil. Revista de Processo. São Paulo: Revista dos Tribunais, n.5, ano 2, 1977, p. 128-159.

Formazioni sociali e interessi di gruppo davanti alla giustizia civile. Rivista di Diritto Processualle Civile, Padova: Cedam, 3/361-402, ano XXV, 1975.

Processo, Ideologia e Sociedade. Vol. I. Tradução e notas de Elício de Cresci Sobrinho. Porto Alegre: Sérgio Antonio Fabris Ed., 2008.

CAPPELlETTI, Mauro; GARTH, Bryant. Acesso à justiça (Trad. Ellen Gracie Northfleet). Porto Alegre: Sérgio Fabris Editor, 2002.

CARRATTA, A., Profili processuali della tutela deglio interessi collettivi e diffusi. Torino: Lanfranchi, 2003.

CENEVIVA, Walter. Lei dos Registros Públicos comentada. 16.ed. São Paulo: Saraiva, 2005.

CHIOVENDA, Giuseppe. Instituições de Direito Processual Civil. vol 1. Campinas: Bookseller, 1998.

COELHO, Fábio Ulhoa. Curso de Direito Civil. v.1. São Paulo: Saraiva, 2003.

COMOGLIO, Luigi Paolo. Etica e Tecnica del "Giusto Processo". Torino: G. Giappichelli Editore, 2004.

CORREA DE OLIVEIRA, J. Lamartine. A dupla crise da Pessoa Jurídica. São Paulo: Saraiva, 1979.

COSTA, Susana Henriques. O processo coletivo na tutela do patrimônio público e da moralidade administrativa - ação de improbidade administrativa, ação civil pública e ação popular. São Paulo: Quartier Latin, 2009.

Popular. São Paulo: Quartier Latin, 2006.

. Comentários à Lei de Ação Civil Pública e Lei de Ação . Condições da Ação. São Paulo: Quartier Latin, 2005.

O controle judicial da representatividade adequada: uma análise dos sistemas norte-americano e brasileiro. In: Carlos Alberto de Salles (coord.). As grandes transformações do processo civil brasileiro - estudos em homenagem ao professor Kazuo Watanabe. São Paulo: Quartier Latin: 2009, p. 953-979.

CUSTÓDIO, Helita Barreira. Associações e fundações de utilidade pública. São Paulo: RT, 1979.

DENTI, Vittorio. Profili civilistici della tutela degli interessi diffusi in Strumenti per La tutela degli interessi difussi della collettivitá - Atti del Convegno Nazionale Bologna - 5 dicembre, 1981, Rimini, 1982. 
DIDIER JR., Fredie. Pressupostos processuais e condições da ação - o juízo de admissibilidade do processo. São Paulo: Saraiva, 2010.

DIDIER JR, Fredie; ZANETI JR., Hermes. Curso de Direito Processual Civil: processo coletivo, v. 4, $5^{\text {a} E d}$., Salvador: JusPodium, 2010.

DINAMARCO, Cândido Rangel. Instituições de Direito Processual Civil. v.1, 5.ed. São Paulo: Malheiros, 2005.

São Paulo: Malheiros 2002. Instituições de Direito Processual Civil. v.1, 2. ed. Instituições de Direito Processual Civil. v.2. 5.ed. São

Paulo: Malheiros, 2001.

A instrumentalidade do processo. 6. ed. São Paulo:

Malheiros, 1998.

DINAMARCO, Pedro. Ação Civil Pública. São Paulo: Saraiva, 2001.

DINIZ, Gustavo Saad. Direito das fundações privadas. Revista Jurídica, Brasília: Brasília Jurídica, n²251, 2008.

EICHHOLTZ, Stephanie. Die US- amerikanische Class Action und ihre detschen Funktionsäquivalente. Tübingen: Mohr Siebeck, 2002.

FABRÍCIO, Adroaldo Furtado. Extinção do Processo e Mérito da Causa. Revista de Processo, São Paulo, n. 58, abr/jun de 1990.

FERRARA, Francesco. Teoria delle persone giuridiche. 2.ed. Napoli/Torino: Eugenio Marguieri/Unione Tip Editrice Torino, 1923.

FERRARA, R. Commentario breve alle leggi sulla giustizia amministrativa. Padova: A. Romano, 2001.

FERRARESI, Eurico. Ação popular, Ação Civil Pública e mandado de segurança coletivo. Rio de Janeiro: Forense, 2009.

FERREIRA FILHO, Manoel Gonçalves. Direitos Humanos Fundamentais. São Paulo: Saraiva, 1995.

FISS, Owen. Um novo processo civil. São Paulo: Ed. RT, 2004.

FORNACIARI, Flávia Hellmeister Clito. Representatividade Adequada nos processos coletivos. 2010. 189 f. Dissertação sob orientação da professora Ada Pellegrini Grinover (Doutorado em Direito Processual Civil) Faculdade de Direito da Universidade de São Paulo, São Paulo, 2010. 
FRANÇA, Erasmo Valladão Azevedo e Novaes. Temas de direito societário, falimentar e teoria da empresa. São Paulo: Malheiros, 2009.

FREIRE, Rodrigo da Cunha Lima. Condições da Ação, enfoque sobre o interesse de agir no processo civil brasileiro. São Paulo: Ed. RT, 2000.

FRIDENTHAL, Jack H., KANE, Mary Kay; MILLER, Arthur R. Civil Procedure. $2^{\text {nd }}$ ed. St. Paul: West Publishing Co., 1993.

FRITZ, Karina Nunes. Boa-fé objetiva na fase pré-contratual - a responsabilidade précontratual por ruptura das negociações. Curitiba: Juruá, 2009.

FUSARO, Andrea. L'associazione non riconosciuta: modelli normativi ed esperienze atipiche. Padova: Cedam, 1991.

GIDI, Antonio. A Class Action como instrumento de tutela coletiva dos direitos - as ações coletivas em uma perspectiva comparada. São Paulo: RT, 2007.

La representation adequada em las acciones Colectivas Brasileñas y el avance del Codigo Modelo. In: GIDI, Antonio; MAC-GREGOR, Eduardo Ferrer (coords.). La tutela de los derechos difusos, colectivos e individuales homogeneos:hacia um Codigo Modelo para Iberoamerica. Cidade do México: Ed. Pórrua, 2004.

A representação adequada nas ações coletivas brasileiras: uma proposta. Revista de processo, São Paulo:RT, n.108, out-dez, 2002.

1995.

. Coisa julgada e litispendência nas ações coletivas. São Paulo: Saraiva,

GOMES, Orlando. Introdução ao Direito Civil. 13. ed. Rio de Janeiro: Forense, 1996.

GRINOVER, Ada Pellegrini. Legitimidade da Defensoria Pública para Ação Civil Pública. Revista de Processo, RT: São Paulo, v. 165, nov/2008.

. Direito Processual Coletivo. In: Paulo Henrique dos Santos Lucon (coord.). Tutela Coletiva: 20 anos da Lei da Ação Civil Pública e do Fundo de Defesa dos Direitos Difusos, 15 anos do Código de Defesa do Consumidor. São Paulo: Ed. Atlas, 2006.

- Novas questões sobre a legitimação e a coisa julgada nas ações coletivas. In: GRINOVER, Ada Pellegrini. O processo - estudos e pareceres. 2. ed. São Paulo: Ed. DPJ, 2002.

Da Class Actions for damages à ação de classe brasileira: os requisitos de admissibilidade. Revista de Processo, São Paulo: RT, ano 26, n.101, 2001, p.11-27. 
Significado social, político e jurídico da tutela dos interesses difusos. Revista de processo, São Paulo: Editora Revista dos Tribunais, n. 97, p. 9-15, jan$\operatorname{mar} / 2000$.

A ação popular portuguesa: uma análise comparativa. In GRINOVER, Ada Pellegrini. A marcha do processo. Rio de Janeiro: Forense Universitária, 2000.

Acesso à justiça e o Código de Defesa do Consumidor. In: GRINOVER, Ada Pellegrini. O Processo em evolução. Rio de Janeiro: Forense Universitária, 1996.

. O conteúdo da garantia do contraditório. In: GRINOVER, Ada Pellegrini. Novas tendências do direito processual. Rio de Janeiro: Forense Universitária, 1990.

. Defesa, contraditório e par conditio na ótica do processo de estrutura cooperatória. In: GRINOVER, Ada Pellegrini. O processo constitucional em marcha. São Paulo: Max Limonad, 1985.

GRINOVER, Ada Pellegrini. A tutela jurisdicional dos interesses difusos. In: Novas Tendências do Direito Processual Civil. In. GRINOVER, Ada Pellegrini. Novas Tendências do Direito Processual. Rio de Janeiro: Forense Universitária, 2a ed., 1990.

RT, 1973.

. As garantias constitucionais do Direito de Ação. São Paulo:

GRINOVER, Ada Pellegrini; WATANABE, Kazuo; NERY JUNIOR, Nelson. Código Brasileiro de Defesa do Consumidor comentado pelos autores do anteprojeto. vol II. 10. ed. Rio de Janeiro: Forense, 2011.

GRINOVER, Ada Pellegrini; WATANABE, Kazuo; MULlENIX, Linda. Os processos coletivos nos países de Civil Law e Common Law - uma análise de direitos comparados. 2. ed. São Paulo: RT, 2011.

GRINOVER, Ada Pellegrini (et alli). Código Brasileiro de Defesa do Consumidor comentado pelos autores do anteprojeto. 8. ed. Rio de Janeiro: Forense Universitária, 2005 .

HENSLER, Deborah (et. alli). Class Action Dilemmas - pursuing public goals for private gain. Santa Monica, California: Ed. RAND, 2000.

HENSLER, Deborah R.; HODGES, Christopher; TULIBACKA, Magdalena (et. alli). The Globalization of Class Action: The annals of the American academy of political and social science. Thousand Oaks, California: Sage Publications, Vol. 622, March 2009.

HOBSBAWM, Eric J. A era das revoluções. 19. ed., São Paulo: Editora Paz e Terra, 2005 . 
HUBERMAN, Leo. A história da riqueza do homem. 21.ed. Rio de Janeiro: Guanabara, 1986.

JOSSERAND, Louis. Cours de droit civil positif français. 2.ed. Paris: Sirey, 1932.

JUNQUEIRA DE AZEVEDO, Antonio. Novos estudos e pareceres de direito privado. São Paulo: Saraiva, 2009.

eficácia. 4. ed. São Paulo: Saraiva, 2007.

$$
\text { Negócio Jurídico - existência, validade e }
$$

. Natureza Jurídica do Contrato de Consórcio.

São Paulo: RT, no 832, Ano 94, fev. 2005.

Insuficiências, deficiências e desatualização do projeto de Código Civil (atualmente, código aprovado) na questão de boa-fé objetiva nos contratos. In: JUNQUEIRA DE AZEVEDO, Antonio. Estudos e pareceres de direito privado. São Paulo: Saraiva, 2004.

JUSTEN FILHO, Marçal. Curso de Direito Administrativo. 2. ed. São Paulo: Saraiva, 2006.

KLAGES, Philipp. Die Natur der Aktiengesellschaft - Anmerkungen zum Bedeutungswandel einer aktienrechtlichen Schlüsserkategorie, In: REHBERG, KarlSiegbert (coord.). Verhandlungsband des 33. DGS-Kongresses in Kassel (CD-Rom), disponível em http://www.ssoar.info/ssoar/files/dgs/33-2006/5729.pdf. Acessado em: 13mar.2011.

LARENZ, Karl. Metodologia da ciência do direito (Tradução: José Lamego). 3. ed. Lisboa: Calouste Gulbekian, 1997.

LARENZ, Karl; WOLF, Manfred. Allgemeiner Teil des Bürgerlichen Rechts. 9.ed. München: C.H. Beck, 2004.

LEE ANDERSON. Preserving adequacy of representation when dropping claims in class action. Kansas City, Missouri: UMKC Law Rewiew, vol. 74:1, 2005.

LENZA, Pedro. Teoria Geral da Ação Civil Pública. 2.ed. São Paulo: RT, 2007.

LEONARDO, Rodrigo Xavier. As associações em sentido estrito no direito privado. 2006. 258f. Tese (Doutorado em Direito Civil) sob a orientação do Prof. Alcides Tomasetti Jr. - Faculdade de Direito, Universidade de São Paulo, São Paulo, 2006.

. A reforma do direito das associações sem fins econômicos pela Lei nº 11.127 de 2005 e o terceiro setor. Revista de Direito do Terceiro Setor, Belo Horizonte: Editora Fórum, ano 1, n.1, jan/jun 2007.

LEONEL, Ricardo de Barros. Manual do Processo Coletivo. 2. ed. São Paulo: RT, 2011. 
LIEBMAN, Enrico Tullio. Manual de Direito Processual Civil. Rio de Janeiro: Forense, 1984.

Malheiros, 2005.

Manual de Direito Processual Civil. vol 1. 3. ed. São Paulo:

LOPES, Teresa Ancona. Exercício do direito e suas limitações: abuso do direito. Revista dos Tribunais, São Paulo:RT, n. 885, julho de 2009, 98 ano, 49-68.

LOUREIRO, Luiz Guilherme. Contratos no novo código civil: teoria geral e contratos em espécie. São Paulo: Método, 2005.

Paulo: Método, 2002.

. Teoria geral dos contratos no novo código civil. São

LUCON, Paulo Henrique dos Santos; GABBAY, Daniela Monteiro. Superação do modelo processual rígido pelo anteprojeto do Código Brasileiro de Processos Coletivos, à luz da atividade gerencial do juiz. In: Ada Pellegrini Grinover (et. alli). Direito Processual Coletivo e o anteprojeto de código brasileiro de processos coletivos. São Paulo: Ed. RT, 2007.

LUHMANN, Niklas. Legitimação pelo procedimento. Série Pensamento Político. Brasília: Ed. Universidade Brasiliense, 1980.

LYN BASSETT, Debra. When reform is not enough: Assuring more than 'adequate' representation in class actions. Georgia: Georgia Law Review, vol. 30:927, 2004.

MANCUSO, Rodolfo de Camargo. Ação Popular - proteção do erário, do patrimônio público, da moralidade administrativa e do meio ambiente. 6. ed. São Paulo: Ed. RT, 2008.

das ações coletivas. São Paulo: RT, 2006.

Jurisdição Coletiva e Coisa Julgada - teoria geral Ação Civil Pública, em defesa do meio ambiente, do patrimônio cultural e dos consumidores. São Paulo: Ed. RT, 2004.

São Paulo: RT, 2000.

Interesses difusos: conceito e legitimação para agir.

MANCUSO, Rodolfo de Camargo; BEGA, Carolina Brambila. A reiterada legitimidade da Defensoria Pública para o ajuizamento de ações coletivas. In: MILARÉ, Edis (coord). A Ação Civil Publica após 25 anos. São Paulo, RT, 2010.

MARCONDES, Sylvio. Problemas de Direito Mercantil. São Paulo: Max Limonad, 1970.

MARCONI, Marina de Andrade; LAKATOS, Eva Maria. Técnicas de pesquisa: planejamento e execução de pesquisas, amostragens e técnicas de pesquisa, elaboração, análise e interpretação de dados. 4. ed. rev. e ampl. São Paulo: Atlas, 1999. 
MARTINS, Sérgio Pinto. Direito do Trabalho. 19. ed. São Paulo: Ed. Atlas, 2004.

MAZZILLI, Hugo Nigro. A defesa dos interesses difusos em juízo: meio ambiente, consumidor, patrimônio cultural, patrimônio público e outros interesses. São Paulo: Saraiva, 2002.

A atuação do Ministério Público nas ações coletivas - o Ministério Público e a defesa dos interesses individuais homogêneos. In: GOZZOLI, Maria Clara; CIANCI, Mirna; CALMON, Petrônio e QUARTIERI, Rita et alli (coord.) Em defesa de um novo sistema de processos coletivos - estudos em homenagem a Ada Pellegrini Grinover. São Paulo: Ed. Saraiva, 2010.

MCCONVILLE, Mike; CHUI, Wing Hong. Research Methods for Law. Edimburg: Edimburg University Press, 2007.

MENDES, Aluísio Gonçalves de Castro. Ações coletivas no direito comparado e nacional (temas atuais de processo civil - v. 4). 2. ed. Revista e atualizada. São Paulo: Ed. RT, 2010.

O anteprojeto de Código Brasileiro de Processos Coletivos e a Legitimidade da Defensoria Pública para Ações Coletivas. In: SOUZA, José Augusto Garcia (coord). A Defensoria Pública e os processos coletivos. Rio de Janeiro: Lumen Juris, 2008.

MENEZES CORDEIRO, António Manuel da Rocha. Da boa fé no direito civil. Coimbra: Almedina, 2007.

direito de ação e culpa “in agendo". 2. ed. Coimbra: Almedina, 2011.

MIRRA, Luiz Álvaro Valery. Associações civis e a defesa dos interesses difusos em juízo: do direito vigente ao direito projetado. In: GRINOVER, Ada Pellegrini (coord.). Direito Processual Coletivo e anteprojeto de Código Brasileiro de Processos Coletivos. São Paulo: RT, 2007.

MORELLO, Augusto Mario. La tutela de los intereses difusos en el derecho argentino legitimaciones, medidas cautelares, trámite y efectos del amparo colectivo. La Plata: Libreria Editora Platense, 1999.

MOTA PINTO, Carlos Alberto da. Teoria geral do direito civil. 4. ed. atualizada por Antonio Pinto Monteiro e Paulo Mota Pinto. Coimbra: Coimbra, 2005.

MULLENIX, Linda. Taking adequacy seriously: the inadequate assessment of adequacy in litigation and settlement classes. Nashville: Vanderbilt Law Rewiew, vol. 57:5:1687, 2004.

NERY JUNIOR, Nelson. Princípios do Processo Civil na Constituição Federal. 3.ed. São Paulo: RT, 1996. 
Paulo: RT, 1992.

Princípios do Processo Civil na Constituição Federal. São

NERY JUNIOR, Nelson; NERY, Rosa Maria de Andrade. Código Civil comentado. 6. ed. São Paulo: RT, 2008.

Comentado. 5.ed. São Paulo: Saraiva: 2001, p. 1885.

Código de Processo Civil

NUNES, Rizzatto. Comentários ao Código de Defesa do Consumidor. 2. ed. Reformulada. São Paulo: Saraiva, 2006.

OLIVEIRA, Carlos Alberto Álvaro de. Efetividade e processo de conhecimento. Revista da Faculdade de Direito da Universidade Federal do Rio Grande do Sul, Porto Alegre, n.16, 1999.

PASCHOAL, Maximilian Fierro. A representatividade adequada na ação coletiva brasileira (lei da ação civil pública e código de defesa do consumidor). 2006, $342 f$. Dissertação (Mestrado em Direito Processual Civil) - Faculdade de Direito da Universidade de São Paulo, sob a orientação do Professor Kazuo Watanabe, São Paulo, 2006.

A representatividade adequada e a discussão quanto à possibilidade do seu controle judicial no Brasil. In: SALLES, Carlos Alberto (coord.). As grandes transformações do processo civil brasileiro - homenagem ao professor Kazuo Watanabe. São Paulo: Quartier Latin, 2009, p. 883-914.

PENTEADO, Luciano de Camargo. Direito das Coisas. São Paulo: RT, 2008.

PONTES DE MIRANDA, Francisco Cavalcanti. Tratados das Ações. tomo I. Bookseller: Campinas, 1998.

Comentários à constituição de 1967 com a ementa n.I de 1969. 2. ed. São Paulo: RT, 1971.

Tratado de Direito Privado. 3.ed.

tomos I e XLIX. Rio de Janeiro: Borsoi, 1970.

(os três caminhos). São Paulo: José Olympio, 1945.

Democracia, liberdade e igualdade

POSNER, Richard A. Economic analysis of law. 5. ed. Aspen: A division of Aspens Publishers, Aspen Law \& business, 1998.

RIZZARDO, Arnaldo. Parte geral do código civil. Rio de Janeiro: Forense, 2003.

ROUSSEAU, Jean-Jacques. Do contrato social (Tradução: Lourdes Santos Machado). 5. ed. São Paulo: Nova Cultural, 1991. 
SALLES, Carlos Alberto. Ações Coletivas: premissas para comparação com o sistema norte-americano. In: SALLES, Carlos Alberto (et. Alli.). Processos Coletivos e Tutela Ambiental. Santos: Ed. Unisantos, 2006.

SALOMÃO FILHO, Calixto. Função Social do Contrato: primeiras anotações. Revista de Direito Mercantil, Industrial, econômico e financeiro, São Paulo: Malheiros, n.32, ano XLII, p.7-24, out/dez 2003.

SAMPAIO, Marcus Vinícius de Abreu. O poder geral de cautela do juiz. São Paulo: RT, 1993.

SHIMURA, Sérgio. Tutela coletiva e sua efetividade. São Paulo: Editora Método, 2006.

SILVA, F. Nicolau dos Santos. Os interesses supraindividuais e a legitimidade processual civil activa. Coimbra: Quid Juris, 2002.

SILVA, José Afonso da. Comentário Contextual à Constituição. 3.ed. São Paulo: Malheiros, 2007.

SIMONETTO, Ernesto. Società e mutualità. Rivista di diritto civile, Padova, ano X, n.4, Lug/Ago, 1964.

SOLARI, Gioeli. Socialismo e diritto privato - Influenza delle odierne dottrine socialiste sul diritto privato. Milano: P. Ungari, 1980.

SOMMA, Alessandro. Autonomia Privata. Rivista di diritto civile, Padova, ano XLVI, $\mathrm{n}$. 4, 2000.

SOUZA SANTOS, Boaventura. Introdução à sociologia da administração da Justiça. Revista de Processo, São Paulo, n.37, jan.-mar., 1985.

SZTAJN, Rachel. Associações e Sociedades. Revista de Direito Mercantil, Nova série, ano XLI, n.128, São Paulo: Ed. Malheiros, out./dez. 2002, p. 15-26.

TARUFFO, Michelle. Abuso de direitos processuais: padrões comparativos de lealdade processual (relatório geral).Revista de Processo, São Paulo, REPRO 177, 2009.

TEIXEIRA, Sálvio de Figueiredo (coord.). Comentário ao Novo Código Civil. Volume I. Rio de Janeiro: Forense, 2010.

THEODORO JUNIOR, Humberto. Abuso de Direito Processual no Ordenamento Jurídico Brasileiro. In Abuso dos Direitos Processuais. MOREIRA, José Carlos Barbosa (coord.). Rio de Janeiro: Editora Forense, 2000.

Vol 3. Rio de Janeiro: Forense, 2003.

. Comentários ao novo código civil. tomo 1.

TROCKER, Nicolo. Interessi collettivi e diffusi. Enc. Giur. Treccani, Roma, XVII, 1989. 
TUCCI, José Rogério Cruz. A causa petendi no direito processual civil brasileiro. 2. ed. São Paulo: Ed. RT, 2001.

diversificações conceptuais. São Paulo: Saraiva, 1990.

“Class Action” e mandado de segurança coletivo:

VADELL, Lorezo Bujosa. La Proteccion Jurisdiccional de los interesses de Grupo. Barcelona: José M. A. Bosch Editor S.A, 1995.

VENTURI, Elton. Comentários ao Código Modelo de Processos Coletivos, um diálogo Ibéro-Americano. Salvador: Ed. Juspodivm, 2009.

Processo civil coletivo: A tutela jurisdicional dos direitos difusos, coletivos e individuais homogêneos no Brasil. Perspectivas de um Código Brasileiro de Processos Coletivos. São Paulo: Malheiros, 2007.

VIGLIAR, José Marcelo de Menezes. Defendant class action brasileira: limites propostos para o "Código de Processos Coletivos". In GRINOVER, Ada Pellegrini et alli (coord.). Direito processual coletivo e anteprojeto de Código Brasileiro de Processos Coletivos. São Paulo: RT, 2007.

homogêneos, vol.III. In: Fredie Didier (coord.) Estudos em Homenagem a Eduardo Espínola, Coleção temas de processo civil. Salvador: Ed. Jus Podium, 2006.

VIGORITI, Vincenzo. Metodi e prospettive di uma recente giurisprudenza in tema di interessi diffusi e collettivi. Giurisprudenza Italiana, n.305, IV, 1980;

Giufrè, 1979.

Interessi collettivi e processo - la legittimazioni ad agire. Milão:

WAMBIER. Teresa Arruda Alvim. O juiz como "administrador" do processo. In: SALLES, Carlos Alberto (coord.). As grandes transformações do processo civil brasileiro - homenagem ao professor Kazuo Watanabe. São Paulo: Quartier Latin, 2009, p. 733-738.

WATANABE, Kazuo. Processo civil e interesse público: introdução. In: SALLES, Carlos Alberto (org.). Processo Civil e interesse público - o processo como instrumento de defesa social. São Paulo: RT, 2003.

WATSON, Gary D. Las Actiones Colectivas en Canadá. In: GIDI, Antonio; MACGREGOR, Eduardo Ferrer. Processos Colectivos - la tutela de los derechos difusos, colectivos e individuales em uma perspectiva comparada. Cidadade do México - DF: Editorial Porrúa, 2003.

WIEDMANN, Herbert. Gesellschaftsrecht. Band I, München: C. H. Beck, 1980. 
YEAZELL, Stephen C. From medieval group litigation to the modern class action. New Haven: Yale University Press, 1987.

ZAVASCKI, Teori Albino. Processo Coletivo - tutela de direitos coletivos e tutela coletiva de direitos. São Paulo: Editora RT, 2006.

ZIMMERMANN, Reinhard. The new German Law of obligations: historical and comparative perspectives. Oxford: Oxford University Press, 2010.

\section{Websites consultados}

ARGENTINA, Guía del Estado. Disponível em: <http://www.argentina.gov.ar/argentina/ portal/paginas.dhtml?pagina=356>. Acessado em: $12 \mathrm{abr} .2010$.

BERIZONCE, Roberto; GRINOVER, Ada Pellegrini; SOSA, Angel Landoni. Exposição de Motivos do Código Modelo de Processos Coletivos para Ibero-América. PUC-SP, Outubro de 2004, disponível em <http://www.pucsp.br/tutelacoletiva/download/ codigomodelo_exposicaodemotivos_2_28_2_2005.pdf>. Acessado em: 23 mai. 2010.

BONÍCIO, Marcelo José Magalhães. Breve análise comparativa entre a tutela dos interesses difusos no direito argentino e no direito brasileiro. Mundo Jurídico, 2005. Disponível em: <http://www.mundojuridico.adv.br/sis_artigos/artigos.asp?codigo=271>. Acessado em: 27dez.2012.

CAMARA, Comissão de Constituição e Justiça e de Cidadania. Projeto de Lei $\mathbf{n}^{\mathbf{0}}$ 5.139, de 2009 (do Poder Executivo), 2010. Disponível em: <http://www.camara.gov.br/ proposicoesWeb/prop_mostrarintegra;jsessionid=BF3B6339770A1552CD90D32EF1E7A B1C.node2?codteor $=754582 \&$ filename $=$ Parecer-CCJC-17-03-2010 $>$. Acessado em: 15out.2012.

CÂMARA DOS DEPUTADOS. PL 5139/2009 (Projeto de Lei). Disponível em: $<$ http://www.camara.gov.br/proposicoesWeb/fichadetramitacao?idProposicao=432485>. Acessado em: 20jun.2011.

CELS. Amparo colectivo por derecho a la salud - Caso Viceconte, 2007. Disponível em: $<$ http://www.cels.org.ar/documentos/index.php?info=detalleDoc\&ids=3\&lang=es\&ss= \&idc $=601 .>$. Acessado em: 25abr.2010.

CONSULTOR JURÍDICO (CONJUR). Associação de fumantes e ex-fumantes não pode propor ação judicial, 2004. Disponível: <http://www.conjur.com.br/2004-out08/associacao_fumantes_ex-fumantes_nao_propor_acao>. Acessado em: 12set.2012.

CORNELL UNIVERSITY LAW SCHOOL. Brown v. Board of Education of Topeka (no.1.) Disponível em: <http://www.law.cornell.edu/supct/html/historics/ USSC_CR_0347_0483_ZO.html>. Acessado em: 21 jun. 2011.

GRINOVER, Ada Pellegrini. Anteprojeto de Código Brasileiro de Processos Coletivos. Associação Nacional do Ministério Público, 2007. Disponível em: 
<http://www.mpcon.org.br/site/portal/jurisprudencias_detalhe.asp?campo=2897>. Acessado em: 28 jun.2011.

IDEC. MOBILIZE-SE - Eventos. Disponível em: <http://www.idec.org.br/mobilizese/eventos>. Acessado em: 15 out.2012.

MAZZEI, Rodrigo Reis. Tutela Colectiva em Portugal: uma breve resenha. Verbo Jurídico, 2005. Disponível em <http://www.verbojuridico.com/doutrina/ brasil/br_tutelacolectivaemportugal.pdf>. Acessado em: 15jul.2011.

MPSP, Cômputo do Estado de São Paulo. Relatório Diagnóstico do Ministério Público do Estado de São Paulo - 2002-2009. Disponível em: <http://www.mp.sp.gov.br/portal/ page/portal/home/banco_imagens/flash/RelatorioDiagnostico2011/rdmp43.pdf> Acessado em: 12 set.2012.

OPEN JURIST. 474 F. 2d 67 - Gonzales v. W Cassidy III - United States Court of Appeals, Fifth Circuit, 1973. Disponível em: <http://openjurist.org/474/f2d/67/gonzalesv-w-cassidy-iii>. Acessado em: 18jun.2011.

628 F. 2d 419 - Johnson v. Uncle Ben's Inc- United States Court of

Appeals, Fifth Circuit, 1980. Disponível em: <http://openjurist.org/628/f2d/419/johnsonv-uncle-bens-inc >. Acessado em: 18jun.2011.

PUC, SP. Código Modelo de Processos Coletivos para Ibero-América - Exposição de Motivos, 2005. Disponível em: <http://www.pucsp.br/tutelacoletiva/download/ codigomodelo_exposicaodemotivos_2_28_2_2005.pdf> Acessado em: 23mai.2010.

SENADO FEDERAL. Minuta - Código do Consumidor. Anteprojetos Finais, 2012. Disponível em: <http://www.senado.gov.br/senado/codconsumidor/pdf/ Anteprojetos_finais_14_mar.pdf>. Acessado em: 15out.2012.

$\underline{\text { Websites dos Tribunais brasileiros consultados }}$

SUPERIOR TRIBUNAL DE JUSTIÇA. Disponível em: <http://www.stj.jus.br>.

SUPREMO TRIBUNAL FEDERAL. Disponível em: <http://www.stf.jus.br>.

TRIBUNAL DE JUSTIÇA DO DISTRITO FEDERAL E DOS TERRITÓRIOS. Disponível em: <http://www.tjdft.jus.br>.

TRIBUNAL DE JUSTIÇA DO ESPÍRITO SANTO. Disponível em: $<$ http://www.tjes.jus.br>.

TRIBUNAL DE JUSTIÇA DO MATO GROSSO. Disponível em:<http://www.tjmt.jus.br>. 
TRIBUNAL DE JUSTIÇA DO MATO GROSSO DO SUL. Disponível em: $<$ http://www.tjms.jus.br>.

TRIBUNAL DE JUSTIÇA DE MINAS GERAIS. Disponível em: $<$ http://www.tjmg.jus.br>.

TRIBUNAL DE JUSTIÇA DO PARÁ. Disponível em:<http://www.tjpa.jus.br>.

TRIBUNAL DE JUSTIÇA DO RIO DE JANEIRO. Disponível em:<http://www.tjrj.jus.br>.

TRIBUNAL DE JUSTIÇA DO RIO GRANDE DO SUL. Disponível em: $<$ http://www.tjrs.jus.br>.

TRIBUNAL DE JUSTIÇA DE SÃO PAULO. Disponível em: <http://www.tjsp.jus.br>.

TRIBUNAL DE JUSTIÇA DE SANTA CATARINA. Disponível em: http://www.tjsc.jus.br.

TRIBUNAL DE JUSTIÇA DE SERGIPE. Disponível em: <http://www.tjse.jus.br>. 